Universidad deValladolid

PROGRAMA DE DOCTORADO EN INVESTIGACIÓN EN

CIENCIAS DE LA SALUD

TESIS DOCTORAL:

\title{
PAPEL DE LA ISOFORMA MITOCONDRIAL DE FASTK EN LA MODULACIÓN DE LA FAGOCITOSIS NO OPSÓNICA DE BACTERIAS POR LOS MACRÓFAGOS
}

\author{
Presentada por Ana García del Río \\ para optar al grado de \\ Doctora por la Universidad de Valladolid
}

Dirigida por:

Dr. Antonio Orduña Domingo

Dra. María Simarro Grande

Dra. María José Castro Alija 

El trabajo realizado en esta tesis ha sido financiado por:

- Consejería de Sanidad JCyL (BIO/VA20/15 y BIO/VA21/15).

- Roche Diagnostics SL. 

En algún lugar, algo increíble está esperando a ser descubierto.

Carl Sagan 



\section{ÍNDICE}

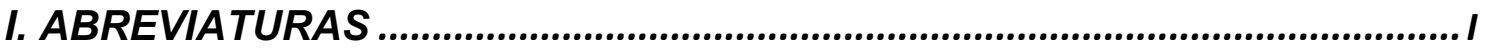

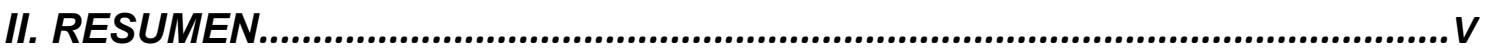

III. INTRODUCCIÓN ....................................................................................... 1

1. El sistema inmunitario innato: los macrófagos y la fagocitosis....................... 1

1.1. Los macrófagos como elementos clave en el sistema inmunitario innato .. 2

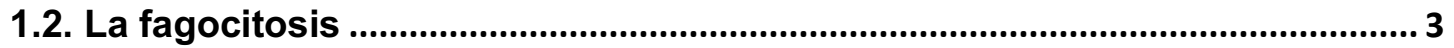

1.2.1. Reconocimiento y vías de señalización .......................................................... 3

1.2.1.1. Receptores de reconocimiento no opsónicos ................................................. 4

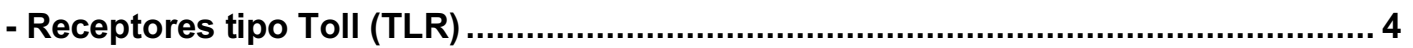

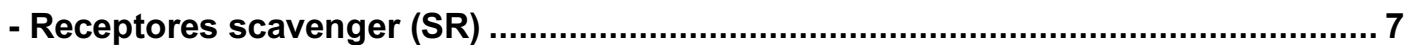

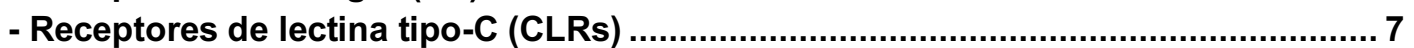

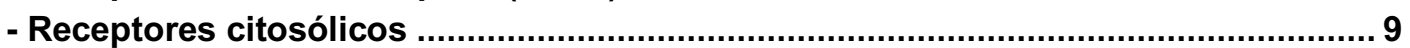

1.2.1.2. Receptores de reconocimiento opsónicos ................................................ 9

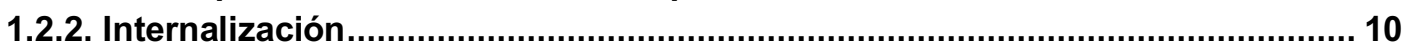

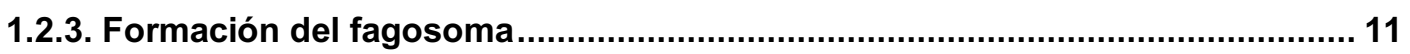

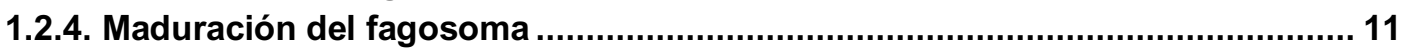

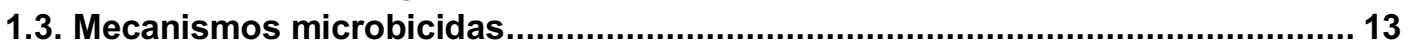

2. La mitocondria en el sistema inmunitario innato............................................... 15

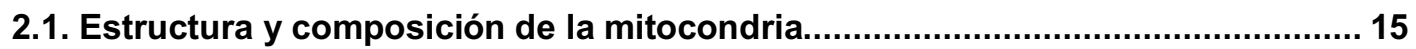

2.2. La cadena respiratoria mitocondrial y la fosforilación oxidativa ......................... 16

2.3. Metabolismo mitocondrial y señalización de la inmunidad innata........................ 18

3. Familia de proteínas mitocondriales FASTK y su papel en el sistema

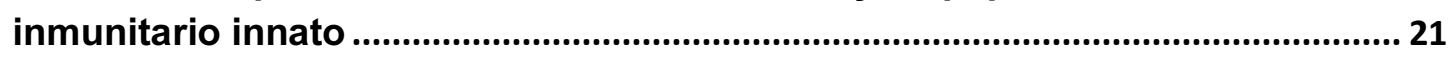

3.1. Reguladores de la expresión génica mitocondrial y de su función .................... 21

3.2. Características estructurales de las proteínas FASTK ….................................... 24

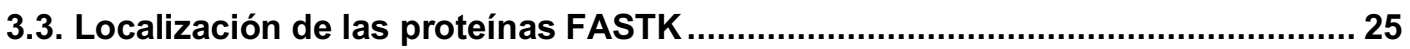

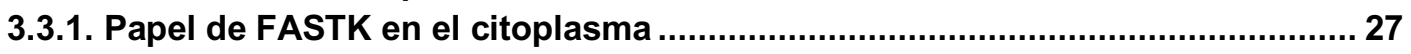

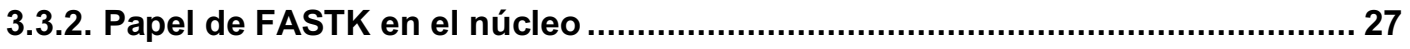

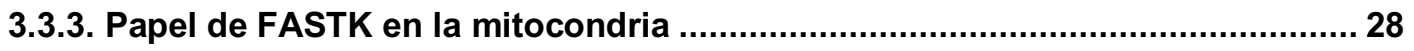

3.4. Miembros de la familia de proteínas FASTK: características, funciones y

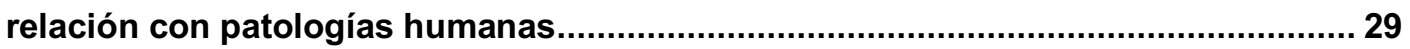

3.5. Papel de FASTK en el sistema inmunitario innato ............................................. 33

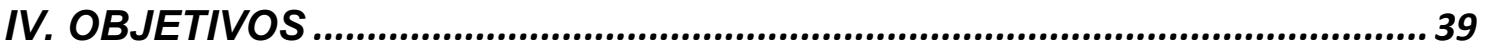

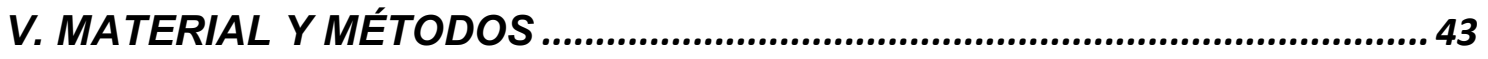

1. Líneas celulares y animales de experimentación ...................................................... 43

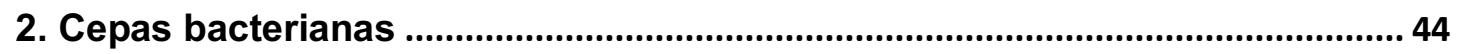

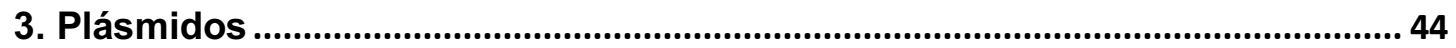

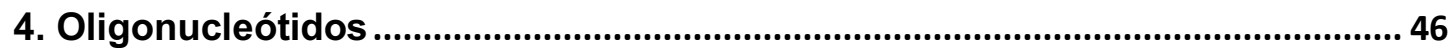




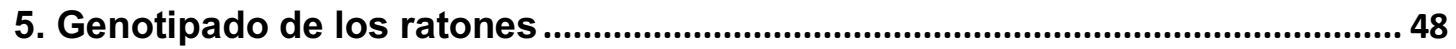

6. Obtención de macrófagos peritoneales.............................................................. 49

7. Ensayo de fagocitosis in vitro en macrófagos ......................................................... 50

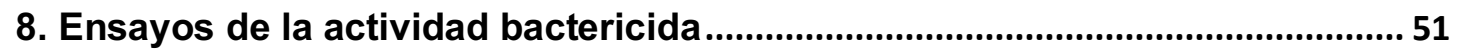

9. Determinación de los radicales libres de oxígeno...............................................55

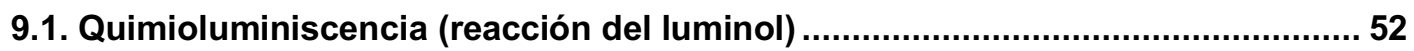

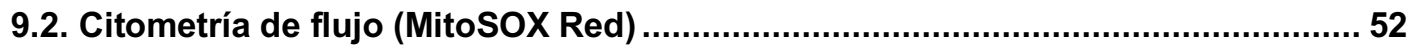

10. Clonación en vectores de expresión................................................................53

10.1. Digestión del vector y anillamiento de oligonucleótidos................................. 53

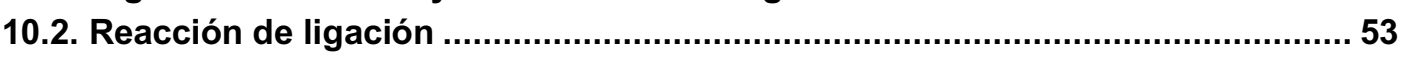

10.3. Preparación de bacterias Escherichia coli DH5 $\alpha$ químicamente competentes 54

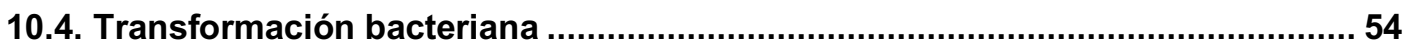

10.5. Purificación de plásmidos a pequeña escala (miniprep) ..................................55

10.6. Purificación de plásmidos a mediana escala (midiprep) …..............................55

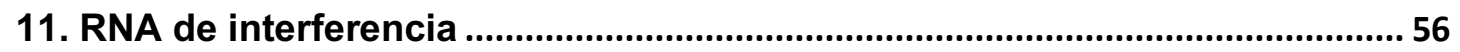

11.1. Producción y transducción de lentivirus.......................................................56

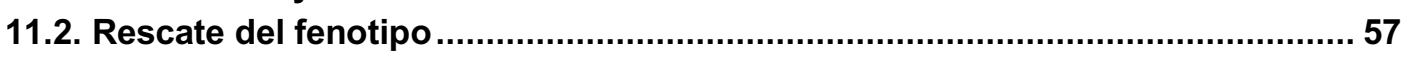

12. Aislamiento de RNA, síntesis de cDNA y PCR cuantitativa a tiempo real

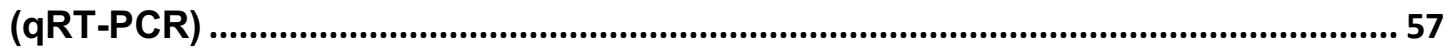

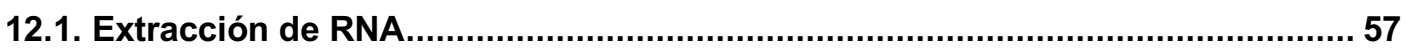

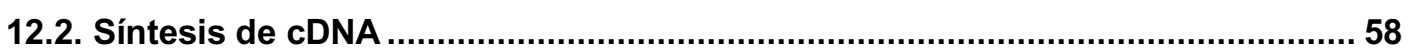

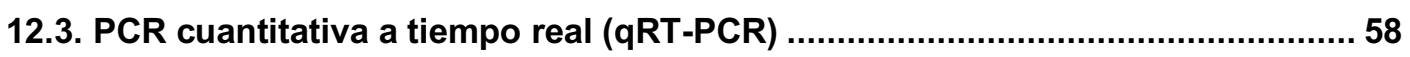

13. Ensayos de apoptosis y viabilidad celular........................................................59

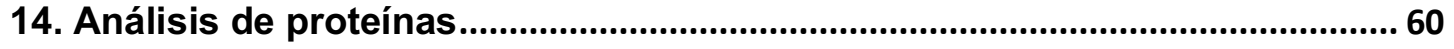

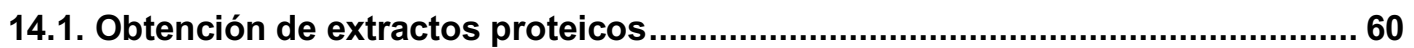

14.2. Electroforesis en gel de poliacrilamida (SDS-PAGE) .....................................60

14.3. Análisis mediante Western blot: transferencia e inmunodetección .................. 61

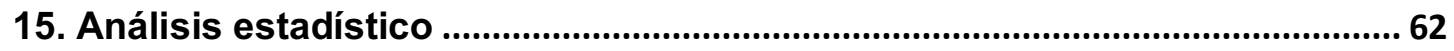

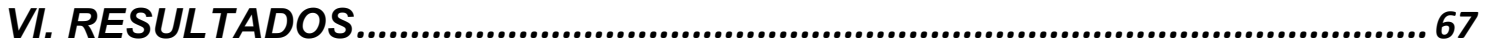

1. Papel del complejo I en la capacidad fagocítica de los macrófagos

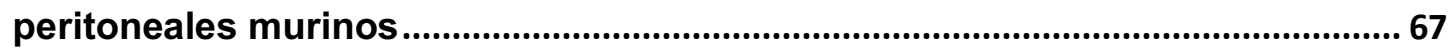

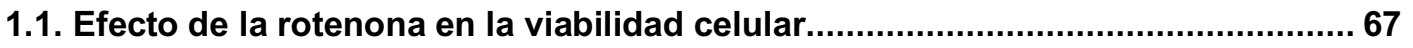

1.2. Efecto de la rotenona en la fagocitosis no opsónica .........................................69

1.3. Efecto de la rotenona en los macrófagos sobre la actividad bactericida ............ 71

2. Análisis de la función del complejo I en la fagocitosis no opsónica en la línea celular RAW 264.7.

2.1. Diseño, síntesis de los oligonucleótidos y clonación de los shRNA en el vector

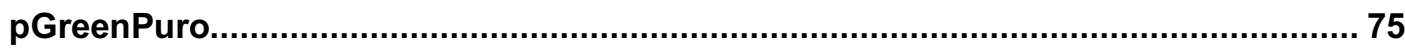

2.2. Producción de partículas virales shRNA y transducción en células ...................77

2.3. Comprobación de la ausencia de NDUFS3, NDUFS4 y FASTK en la línea celular de macrófagos murinos RAW 264.7 mediante qRT-PCR ..........................................78 
2.4. Estudio de la fagocitosis no opsónica en los macrófagos murinos silenciados en NDUFS3, NDUFS4, FASTK, y las células inhibidas farmacológicamente con rotenona

3. Rescate del fenotipo fagocítico de las células RAW 264.7 en las que se ha silenciado FASTK mediante la reexpresión de la isoforma mitocondrial de FASTK

4. Estudio de la activación de AMPK en la fagocitosis no opsónica de bacterias en los macrófagos.

4.1. Efecto del inhibidor de AMPK durante la fagocitosis no opsónica en los macrófagos.

5. Análisis de la generación de los radicales libres de oxígeno mitocondriales en los macrófagos FASTK KO.

VII. DISCUSIÓN. 99

1. El complejo I mitocondrial en la regulación de la fagocitosis no opsónica .. 99

2. El complejo I y el metabolismo mitocondrial en la inmunidad innata 105

3. Mecanismos moleculares en la regulación de la fagocitosis ......................... 108

3.1. AMPK como vía de señalización de la fagocitosis 108

3.2. AMPK y la implicación del citoesqueleto en la fagocitosis 111

3.3. El aumento de ROS mitocondrial en la fagocitosis 112

3.4. Mecanismo molecular de acción propuesto. 117

VIII. CONCLUSIONES 123

IX. BIBLIOGRAFÍA. 127

X. ANEXO I. Secuencias 151

XI. ANEXO II. Divulgación científica. 157 



\section{ABREVIATURAS}

AICAR: del inglés 5-aminoimidazol-4-carboxamida-1- $\beta$-D-ribofuranosida

AMPK: Proteína quinasa activada por AMP (AMP-activated protein kinase)

ATP: Adenosin trifosfato (Adenosine triphosphate)

bp: Pares de bases (Base pair)

Cl: Complejo I

CII: Complejo II

CARD: Caspasa N-terminal (Caspase recruitment domain 9)

cDNA: DNA complementario obtenido a partir de mRNA (Complementary DNA).

CDS: Región codificante (Coding DNA Sequence)

CMV: Citomegalovirus (Cytomegalovirus)

CoQ: Coenzima Q (Coenzyme Q)

CR: Receptor del complemento (Complement receptor)

CR3: Receptor 3 del complemento (Complement receptor 3)

cytoFASTK: Isoforma citoplasmática y nuclear de FASTK

DNA: Ácido desoxirribonucleico (Deoxyribonucleic acid)

DMEM: del inglés Dulbecco's Modified Eagle Medium

ECSIT: Intermediario en la señalización conservado en la vía Toll (Evolutionarily conserved signaling intermediate in Toll pathway)

E. coli: Escherichia coli $\mathrm{DH} 5 \alpha$

EDTA: Ácido etilendiaminotetraacético (Ethylenediaminetetraacetic acid)

ETC: Cadena de transporte de electrones (Electron Transport Chain)

$\mathrm{FADH}_{2}$ : Flavín adenín dinucleótido (Flavin adenine dinucleotide)

FASTK: del inglés Fas-activated Serine/Threonine Kinase

Fcy: Receptor Fc-gamma

FITC: del inglés Fluorescein-5-(6) isothiocyanate

GFP: Proteína fluorescente verde (Green Fluorescent Protein)

GRSF1: del inglés G-Rich RNA Sequence Binding Factor 1

GTPasa: Guanosina trifosfatasa (Guanosine Triphosphatases)

h: Horas

HRP: del inglés horseradish peroxidase

IF: Índice fagocítico

IFN: Interferones

IL-1 $\beta$ : Interleucina-1 beta 
IL-10: Interleucina-10

KO: del inglés knockout

LB: Medio líquido de cultivo bacteriano Luria-Bertani

LPS: Lipopolisacárido

MAPK: Proteína de mitógeno activado kinasa (Mitogen-activated protein kinase)

MFI: Intensidad media de fluorescencia (Mean Fluorescence Intensity)

min: Minutos

mitoFASTK: Isoforma mitocondrial de FASTK

mitoROS: Especies reactivas de oxígeno mitocondriales (Mitochondrial Reactive Oxygen Species)

mRNA: RNA mensajero (messenger RNA)

MT-ND6: del inglés Mitochondrially encoded NADH: Ubiquinone oxidoreductase core subunit 6

mtDNA: DNA mitocondrial

MyD88: Factor de Diferenciación Mieloide 88 (Myeloid Differentiation response protein 88)

NADH: Nicotinamida adenina dinucleótido

NF-K $\beta$ : Factor nuclear $\kappa \beta($ Nuclear Factor $\kappa \beta)$

NLR: Receptores tipo dominios de oligomerización de unión a nucleótido (Nucleotidebinding oligomerization domain (NOD)-Like Receptor)

NOD: Dominios de oligomerización de unión a nucleótido (Nuclear binding oligomerization domain)

NOX: NADPH oxidasas

$\mathrm{O}_{2}^{-}$: Anión superóxido

OXPHOS: Fosforilación oxidativa (Oxidative Phosphorylation System)

PAKs: del inglés $p 21$-activated kinases

PAMPs: Patrones moleculares asociados a patógenos (Pathogen-Associated Molecular Patterns)

PBS: Tampón fosfato salino (Phosphate Buffered Saline)

PCR: Reacción en cadena de la polimerasa (Polymerase Chain Reaction)

PPR: Repetición de pentatricopéptido (Pentapatricopeptide repeat)

PRRs: Receptores de reconocimiento de patrones (Pattern recognition receptors) 
qRT-PCR: PCR cuantitativa a tiempo real (Quantitative Real Time Polymerase Chain reaction)

RAP: acrónimo de RNA-binding domain abundant in Apicomplexans

Rho: del inglés Ras homologous.

RFP: del inglés red fluorescent protein

RLR: Receptores tipo Gen-I Inducible por Ácido Retinoico (Retinoic Acid-Inducible Gene I-Like Receptor)

RNA: Ácido ribonucleico

RNS: Especies reactivas de nitrógeno (Reactive Nitrogen Species)

ROS: Especies reactivas de oxígeno (Reactive Oxygen Species)

rpm: Revoluciones por minuto

rRNA: RNA ribosomal

S. aureus: Staphylococcus aureus

SDS: Dodecil sulfato sódico (Sodium Dodecyl Sulfate)

shRNA: del inglés Short Hairpin RNA

SR: Receptor scavenger (Scavenger Receptor)

TCA: Ciclo del ácido tricarboxílico (Tricarboxylic Acid Cycle)

TLRs: Receptores de tipo Toll (Toll-like receptor)

TNF: Factor de necrosis tumoral

TRAF6: Factor asociado al receptor del factor de necrosis (TNF Receptor-Associated Factor 6)

TRITC: Isotiocianato de tetrametilrodamina (Tetramethylrhodamine-5 (and-6)isothiocyanate)

tRNA: RNA de transferencia

TUNEL: Marcaje de los extremos de las roturas con dUTP por medio de la desoxirribonucleotidil transferasa terminal (Terminal deoxyribonucleotidyl transferase mediated dUTP Nick End Labeling)

U: Unidades

UFC: Unidades formadoras de colonia

Ucp2: Proteína desacoplante 2 (del inglés Uncoupling Protein 2)

UTR: del inglés Untranslated Region

WAVE: del inglés WASp family Verprolin-homologous protein

WT: tipo salvaje (Wild Type) 



\section{RESUMEN}

La mitocondria es un orgánulo esencial para la función celular, incluyendo la generación celular de la energía en forma de ATP a través de la fosforilación oxidativa (OXPHOS) y la oxidación de metabolitos. La proteína de unión a RNA, FASTK (Fas activated serine/threonine kinase), tiene dos isoformas, una localizada en la mitocondria (mitoFASTK), y la otra isoforma en citosol y núcleo (cytoFASTK). Se ha demostrado que la isoforma mitoFASTK es necesaria para la biogénesis del mRNA ND6 mitocondrial, que codifica una subunidad esencial del complejo I de la cadena respiratoria mitocondrial ( $\mathrm{Cl}, \mathrm{NADH}$ :ubiquinona oxidorreductasa). Este estudio investiga los mecanismos de acción de FASTK en la fagocitosis no opsónica.

En nuestro laboratorio se ha observado que los macrófagos de los ratones FASTK KO muestran un aumento en la fagocitosis no opsónica de bacterias y una disminución del $\sim 50 \%$ de la actividad del $\mathrm{Cl}$ en estas células. Durante el trabajo realizado en esta Tesis Doctoral, como método de estudio para explorar si la disminución de la actividad del $\mathrm{Cl}$ explica el fenotipo fagocítico, se empleó el tratamiento con el inhibidor del $\mathrm{Cl}$, rotenona, en los macrófagos murinos WT, así como en la línea celular murina RAW 264.7. En paralelo se silenciaron con shRNAs en dicha línea celular, las dos subunidades del Cl (NDUFS3 y NDUFS4). Se observó que, tanto el tratamiento farmacológico con rotenona como el silenciamiento de las subunidades NDUFS3 y NDUFS4, resultaba en un aumento en la fagocitosis bacteriana no opsónica. La reexpresión de mitoFASTK en los macrófagos silenciados en FASTK rescata el fenotipo (es decir, la fagocitosis vuelve a ser normal). Asimismo, la disminución de la actividad del $\mathrm{Cl}$ en los macrófagos FASTK KO está asociada con un aumento en la fosforilación de AMPK, y su inhibición utilizando el compuesto $C$ revierte el fenotipo fagocítico. Finalmente, se ha demostrado que los macrófagos FASTK KO muestran aumento en la producción de mitoROS respecto a los macrófagos WT durante la fagocitosis no opsónica de bacterias.

En conclusión, estos resultados, demuestran por primera vez que mitoFASTK tiene un papel regulador negativo en la fagocitosis no opsónica de bacterias por los macrófagos, a través de la función del $\mathrm{Cl}$ y la activación de AMPK.

Es de interés ahondar en el conocimiento sobre los mecanismos que explican el fenotipo observado y trasladarlo a modelos in vivo. Estos estudios pueden contribuir a la generación de tratamientos que aumenten la captación y la eliminación de bacterias antes de que causen reacciones inflamatorias exageradas; también pueden ayudar a combatir la invasión bacteriana en lugares anatómicos con cantidad limitada de opsoninas. 

INTRODUCCIÓN 



\section{INTRODUCCIÓN}

\section{El sistema inmunitario innato: los macrófagos y la fagocitosis}

El sistema inmunitario está constituido por un conjunto de células y mecanismos moleculares con capacidad de detectar y eliminar los microorganismos, células apoptóticas y cancerosas. Comprende la inmunidad innata y la adaptativa (Iwasaki y Medzhitov, 2010). En este capítulo se va a tratar la inmunidad innata, en particular la fagocitosis, uno de sus mecanismos clave. El sistema inmunitario innato es evolutivamente el más antiguo de los mecanismos de defensa del huésped, mientras que el sistema inmunitario adaptativo es exclusivo de organismos vertebrados, y genera un conjunto de acciones celulares y humorales específicas frente al estímulo antigénico desarrollando memoria inmunológica (Galluci y Matzinger, 2001; Parkin y Cohen, 2001; Medzhitov, 2007). El sistema inmunitario innato comprende barreras de defensa: físicas, químicas y biológicas. Las barreras físicas incluyen la piel, los epitelios del tracto respiratorio, digestivo y genitourinario, mucus y cilios, impidiendo la entrada de los microorganismos hacia el interior del organismo. Las barreras químicas incluyen el $\mathrm{pH}$ ácido y las sales biliares del aparato digestivo, o la lisozima salivar, entre otras. Las barreras biológicas están constituidas por la microbiota de la piel, boca, y de los tractos genitourinario y gastrointestinal (Male et al., 2013). En el supuesto de que el agente patógeno supere estas barreras se produce un foco infeccioso y la activación de los mecanismos innatos celulares y humorales que tratan de evitar la progresión de la infección. Entre los componentes celulares de este sistema de defensa destacan los monocitos, macrófagos, neutrófilos, células dendríticas, mastocitos, eosinófilos y células Natural Killer (NK); y entre los componentes solubles destacan el sistema del complemento, una gran variedad de citoquinas y las proteínas de fase aguda, como la proteína C reactiva, que proporcionan una defensa inmediata (Medzhitov et al., 2007).

Los macrófagos, neutrófilos y células dendríticas se conocen como células fagocíticas profesionales. En particular, en este capítulo, se destacan los macrófagos, células empleadas durante el estudio de la presente tesis doctoral, que se explican a continuación. Los neutrófilos tienen como función la fagocitosis y la activación de los mecanismos bactericidas a través de enzimas degradantes en vesículas intracelulares en sus gránulos citoplasmáticos. Las células dendríticas tienen como función principal la captación, procesamiento y presentación de antígenos a los linfocitos $\mathrm{T}$; son células presentadoras de antígeno (APC, antigen presenting cell), e inician respuestas adaptativas (Parkin y Cohen, 2001; Flannagan et al., 2012; Geissmann et al., 2010). 


\subsection{Los macrófagos como elementos clave en el sistema inmunitario innato}

Los macrófagos son células fagocíticas con un papel esencial en la respuesta innata a patógenos. Tienen su origen en los monocitos que circulan en la sangre; éstos migran a los tejidos donde se diferencian en macrófagos de varios tipos según su localización, por ejemplo, las células de Kupffer del hígado; las células microgliales del encéfalo; los osteoclastos en los huesos; o los macrófagos alveolares del pulmón. Estas células permanecen inactivas en los tejidos y pueden activarse tras reconocer estímulos a través de ciertos receptores, como se detallará a continuación, desencadenando la respuesta inmunitaria (Male et al., 2013; Gordon y Taylor, 2005). Los macrófagos, además de actuar como centinelas, tienen la capacidad de reconocer, procesar y presentar antígenos a los linfocitos $\mathrm{T}$ en el contexto del complejo mayor de histocompatibilidad. Secretan enzimas, producen los radicales reactivos de oxígeno (ROS, Reactive Oxygen Species) y nitrógeno (RNS, Reactive Nitrogen Species), entre otras moléculas, y mantienen la homeostasis tisular mediante la eliminación de células muertas y restos celulares. Tienen un papel crítico en los procesos de reparación tisular al estimular la angiogénesis y la síntesis de la matriz extracelular (Jenkins y Hume, 2014; Italiani y Boraschi, 2014). Se comunican con otras células del sistema inmunitario a través de la secreción de citoquinas y quimiocinas, modulando la respuesta inflamatoria (Wynn et al., 2013), y reclutan células del sistema inmunitario hacia los focos de inflamación, proceso conocido como quimiotaxis. Entre las citoquinas proinflamatorias producidas por los macrófagos destacan TNF $\alpha$, IL-1 $\beta$, IL-6, IL-18, IL-12, IL-23, entre otras (Tabla 1), y entre las citoquinas antiinflamatorias $\mathrm{IL}-10$ (se producen por macrófagos activados, células $B$, y células T) y TGF- $\beta$.

Tabla 1. Algunas citoquinas producidas por macrófagos y sus funciones biológicas. Tabla de elaboración propia.

\begin{tabular}{|c|c|c|}
\hline Citoquina & Función biológica & Referencias \\
\hline IL-1 $\beta$ & $\begin{array}{l}\text { Citoquina proinflamatoria. Induce la producción de IL-6 y la síntesis de proteínas } \\
\text { de fase aguda en el hígado. Fiebre (pirógeno). Favorece el reclutamiento de } \\
\text { leucocitos al sitio de la infección. }\end{array}$ & $\begin{array}{l}\text { Ben-Sasson et al., } \\
2009 ; \text { Carmi et al., } \\
2009\end{array}$ \\
\hline IL-6 & $\begin{array}{l}\text { Induce la diferenciación de eosinófilos y la producción de IgA. Proliferación de } \\
\text { células productoras de anticuerpos y síntesis de proteínas de fase aguda. }\end{array}$ & $\begin{array}{l}\text { Barkhausen et al., } \\
\text { 2011; Hurst et al., } \\
2001 \text {; Scheller et al., } \\
2011\end{array}$ \\
\hline IL-10 & $\begin{array}{l}\text { Presenta propiedades antiinflamatorias. Inhibe la expresión del complejo MHC II y } \\
\text { de las moléculas coestimuladoras, como CD80 y CD86. Potencia la liberación de } \\
\text { mediadores antiinflamatorios como el antagonista del receptor de IL-1 } \beta \text { o de TNF } \alpha \text {. }\end{array}$ & $\begin{array}{l}\text { Fiorentino et al., 1991; } \\
\text { Chadban et al., } 1998\end{array}$ \\
\hline IL-12 & $\begin{array}{l}\text { Citoquina proinflamatoria. Favorece la producción de IFN- } \gamma \text {, y la diferenciación y } \\
\text { proliferación de las células Th1. }\end{array}$ & Wang et al., 2000 \\
\hline IL-18 & Citoquina proinflamatoria. Inmunomoduladora. Síntesis de IFN- $\gamma$. & Gatti et al., 2002 \\
\hline TNF $\alpha$ & $\begin{array}{l}\text { Citoquina proinflamatoria. Induce apoptosis. En hipotálamo estimula la liberación } \\
\text { de la hormona liberadora de corticotropina. Fiebre. Suprime el apetito. En hígado } \\
\text { activa la síntesis de proteína de fase aguda. }\end{array}$ & $\begin{array}{l}\text { Beutler et al., 1999; } \\
\text { Griffin et al., } 2012\end{array}$ \\
\hline IL-23 & Induce la respuesta Th17 y participa en el desarrollo de la memoria inmunológica. & Stumhofer et al., 2006 \\
\hline
\end{tabular}


Las quimioquinas son un tipo de citoquinas de pequeño tamaño con actividad quimiotáctica en los fagocitos. Las principales quimioquinas que se liberan por los macrófagos son: CXCL1 y CXCL2 (MIP-2 $\alpha$ ), CCL5, CXCL8 (IL-8), CXCL9 (MIG), CXCL10 (IP-10), CXCL11 (IP-9).

La activación de los macrófagos puede, según el estímulo responsable, llevar a la diferenciación hacia los macrófagos tipo M1 o M2. Los macrófagos M1 se generan por estímulos como el lipopolisacárido bacteriano (LPS) y/o IFN- $\gamma$ o TNF $\alpha$, y los macrófagos M2 se originan por la acción de IL-4 o IL-13 (subtipo M2a); expresión a inmunocomplejos junto con LPS o IL-1 $\beta$ (M2b); o por IL-10, TGF $\beta$ o glucocorticoides (M2c). Los macrófagos M1 tienen propiedades bactericidas y promueven las respuestas Th1, mientras que los macrófagos M2 promueven la respuesta inmunitaria de tipo 2 (Th2) fundamental en la respuesta a parásitos, el asma y los trastornos alérgicos. Tienen una función antiinflamatoria, regulan la cicatrización de heridas y reparación de tejidos, y tienen menor actividad bactericida que los macrófagos M1 (Zhang y Wang, 2014; Arango Duque y Descoteaux, 2014; Martínez y Gordon, 2014; Italiani y Boraschi, 2014). Entre las funciones de los macrófagos aquí nos vamos a centrar en la fagocitosis.

\subsection{La fagocitosis}

La fagocitosis es una de las principales funciones de los macrófagos. Durante la fagocitosis están implicados varios mecanismos biológicos: receptores celulares que permiten reconocer a la partícula, la transducción de señales, la reestructuración del citoesqueleto, el movimiento o tráfico de membranas y el transporte de iones (como el calcio). Este proceso biológico se puede dividir en cuatro fases principales que detallaremos a continuación: (i) Reconocimiento del microorganismo y activación de las vías de señalización para iniciar la maquinaria de internalización, (ii) internalización de la partícula, (iii) formación del fagosoma, y (iv) maduración del fagosoma.

\subsubsection{Reconocimiento y vías de señalización}

Los macrófagos expresan gran variedad de receptores de reconocimiento de patrones (PRRs, Pattern Recognition Receptors) que participan en la fagocitosis. Los receptores opsónicos y no opsónicos participan de forma conjunta según el ligando o estímulo detectado, para generar la respuesta inmunitaria y de esta forma llevar a cabo la fagocitosis de microorganismos, como bacterias Gram positivas, bacterias Gram negativas o levaduras, que son reconocidos por una combinación de receptores que se describen a continuación. 


\subsubsection{Receptores de reconocimiento no opsónicos}

La fagocitosis no opsónica se inicia con el reconocimiento de patrones moleculares asociados a patógenos (PAMPs, Pathogen-Associated Molecular Patterns) por los receptores de PAMPs (llamados PRRs) de los fagocitos. Los PAMPs más conocidos son: a) los peptidoglicanos y el ácido lipoteicoico (LTA, Lipoteichoic Acid), para las bacterias Gram positivas; b) lipopolisacáridos (LPS), componente principal de la pared celular de la mayoría de las bacterias Gram negativas; c) lipoproteínas; d) ácidos nucleicos microbianos incluyendo DNA con motivos CpG sin metilar, RNA de doble cadena, RNA de cadena simple, y RNA 5'-trifosfato; e) glicoproteínas de superficie; f) flagelina; g) mananos y $\beta$-glucanos, entre otros PAMPs (Akira et al., 2006).

El reconocimiento del patógeno puede ser directo, a través de PRRs de membrana o citoplasmáticos, o bien de forma indirecta mediante PRRs solubles. La identificación de diferentes microorganismos se debe a la existencia de varias clases de PRRs como a) los receptores Toll-like (TLRs, Toll-Like Receptor) de señalización transmembrana, así como, b) los receptores de tipo scavenger (SR, Scavenger Receptor), c) los receptores lectina tipo C (CLR, C-type Lectin Receptor), y d) los receptores citosólicos: receptores tipo dominios de oligomerización de unión a nucleótido (NLRs, Nucleotide-binding oligomerization domain (NOD)-Like Receptor), y los receptores de tipo Gen-I inducible por ácido retinoico (RLRs, Retinoic Acid-Inducible Gene I-Like Receptor), que permiten identificar diferentes microorganismos.

\section{- Receptores tipo Toll (TLR)}

Los receptores TLR son los receptores mejor caracterizados y están presentes en un conjunto de células relacionadas con la respuesta innata. Difieren en su localización, tipos de ligandos que reconocen y vías de señalización (Tabla 2). Aunque reconocen y se unen a diferentes microorganismos, no funcionan como receptores fagocíticos, y pueden cooperar con otros receptores no opsónicos para estimular la fagocitosis. Estructuralmente, son glicoproteínas y se caracterizan por la presencia de una secuencia extracelular amino-terminal con dominios ricos en leucina (LRR, LeucineRich Repeat) que interviene en el reconocimiento del patógeno, y un dominio de señalización intracelular carboxilo-terminal homólogo al receptor de IL-1 (IL-1R, Interleukin-1 Receptor) denominado TIR (Toll interleukin-1 Receptor), responsable de desencadenar la señalización. Los seres humanos expresan 10 tipos de TLRs (1-10) que comparten características estructurales, y difieren unos de otros en la especificidad de los ligandos y los patrones de expresión, mientras que los ratones expresan 12 tipos de TLRs (TLRs 1-9 y 11-13) (Jeong et al., 2011). 
Los TLR pueden formar heterodímeros y homodímeros entre sí, o complejos con otros receptores. Por ejemplo, el TLR2 forma heterodímeros con TLR1 y TLR6, lo que permite reconocer una variedad amplia de componentes microbianos.

Tabla 2. Características funcionales de los receptores Toll Like (TLRs). Tabla de elaboración propia basada en las fuentes bibliográficas que se detallan a continuación: West et al., 2011b; Akira et al., 2006; Kaway y Akira, 2011; Iwasaki y Medzhitov, 2015.

\begin{tabular}{|c|c|c|c|c|c|}
\hline Receptor & Localización & Ligando & Vía de señalización & Microorganismo & Tipo celular que expresa el TLR \\
\hline TLR1 & Superficie celular & Lipopéptidos & MyD88. NF-kB & $\begin{array}{c}\text { Bacteria Gram } \\
\text { negativa }\end{array}$ & $\begin{array}{c}\text { Monocitos/macrófagos, neutrófilos, } \\
\text { células dendríticas, linfocitos B, } \\
\text { células NK }\end{array}$ \\
\hline $\begin{array}{c}\text { TLR2 } \\
\text { (TLR2/TLR6 } \\
y \\
\text { TLR2/TLR1) }\end{array}$ & $\begin{array}{c}\text { Superficie } \\
\text { celular/endosoma }\end{array}$ & $\begin{array}{c}\text { Ácido } \\
\text { lipoteicoico, } \\
\text { lipoproteinas, } \\
\text { mananos, } \\
\text { peptigoglicano, } \\
\text { lipopéptidos }\end{array}$ & MyD88. NF-kB & $\begin{array}{l}\text { Bacteria Gram } \\
\text { positiva, hongos }\end{array}$ & $\begin{array}{c}\text { Monocitos/macrófagos, neutrófilos, } \\
\text { células dendríticas, mastocitos, } \\
\text { células NK }\end{array}$ \\
\hline TLR3 & Endosoma & dsRNA & TRIF, NF-kB/IRF3 & Virus & $\begin{array}{c}\text { Monocitos, células dendríticas, } \\
\text { linfocitos B }\end{array}$ \\
\hline TLR4 & $\begin{array}{c}\text { Superficie } \\
\text { celular/endosoma }\end{array}$ & $\begin{array}{l}\text { LPS, manano } \\
\text { glicosilfosfatidil } \\
\text { inositol }\end{array}$ & $\begin{array}{c}\text { TRIF/MyD88/Mal/NF } \\
\text {-kB/IRF3 }\end{array}$ & $\begin{array}{c}\text { Bacteria Gram } \\
\text { negativa }\end{array}$ & $\begin{array}{l}\text { Monocitos/macrófagos, neutrófilos, } \\
\text { células dendríticas, mastocitos, } \\
\text { epitelio intestinal, células NK, } \\
\text { linfocitos B y T }\end{array}$ \\
\hline TLR5 & Superficie celular & Flagelina & MyD88, NF-kB & $\begin{array}{c}\text { Flagelo } \\
\text { bacteriano }\end{array}$ & $\begin{array}{l}\text { Monocitos/macrófagos, neutrófilos, } \\
\text { células dendríticas, epitelio intestinal }\end{array}$ \\
\hline TLR7 & Endosoma & ssRNA & MyD88, NF-kB/IRF7 & Virus & $\begin{array}{c}\text { Monocitos/macrófagos, células } \\
\text { dendríticas, linfocitos B }\end{array}$ \\
\hline TLR8 & Endosoma & ssRNA & MyD88, NF-kB/IRF7 & Virus & $\begin{array}{c}\text { Monocitos/macrófagos, células } \\
\text { dendríticas, mastocitos }\end{array}$ \\
\hline TLR9 & Endosoma & $\begin{array}{l}\text { DNA rico en } \\
\text { CpG, DNA sin } \\
\text { metilar }\end{array}$ & MyD88, NF-kB/IRF7 & Bacterias & $\begin{array}{c}\text { Monocitos/macrófagos, células } \\
\text { dendríticas, linfocitos B }\end{array}$ \\
\hline
\end{tabular}

Después de la unión al ligando, los receptores inician una cascada de señalización a través de las moléculas adaptadoras de señal como son: a) MyD88 (Myeloid Differentiation response protein 88) utilizada por todos los TLRs excepto TLR3 (Wang et al., 2014); b) MAL/TIRAP (MyD88-Adapter-Like protein/Toll-Interleukin 1 Receptor domain containing Adaptor Protein, también conocida como MAL) utilizada para la señalización de TLR2 y TLR4, que funciona como conector entre MyD88 y TLR; c) TRIF (TIRAP inducing IFN- $\beta$ ) utilizada por TLR3 y TLR4; y d) TRAM (TRIF-Related Adaptor Molecule) utilizada por TLR4. Estas moléculas adaptadoras actúan como mensajeros que activan quinasas como MAPKs (Mitogen-Activated Protein Kinases), complejo IKK (IKB Kinase), TBK1 (TANK Binding Kinase 1), RIP-1 (Receptor Interacting 
Protein-1), y factores de transcripción como NF-K $\beta$ (Nuclear Factor $\kappa \beta$ ), IRF3 (IFN Regulatory Factor-3) e IRF7, y AP-1 (Activator Protein-1), entre otros (Jeong et al., 2011; Takeda y Akira, 2004) (Figura 1).

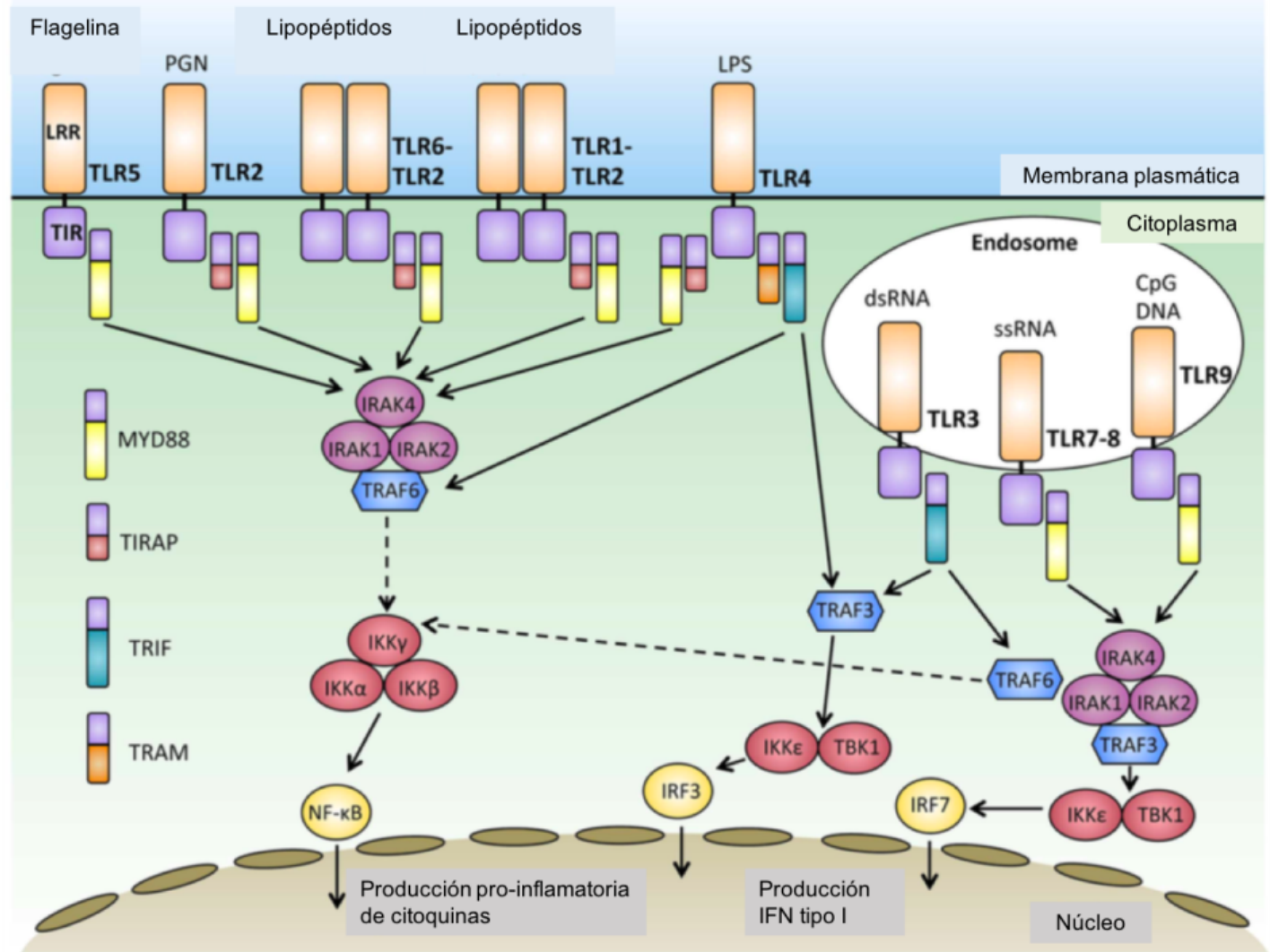

Figura 1. Vías de señalización de los receptores de reconocimiento de patrones. Se representan los TLRs principalmente en membrana y endosomas. Los TLR envían señales a través de Mal/TIRAP y MyD88 o TRAM/TRIF a IRAKITRAF6 para activar las quinasas como MAPKs, IKKs, TBK1, que activan los factores de transcripción NF-K $\beta$, AP-1 e IRF que estimulan la expresión de genes que producen citoquinas, IFNs y enzimas inflamatorias. Imagen adaptada de Wang et al., 2014.

A diferencia de otros TLRs, TLR4 requiere la formación de un complejo de reconocimiento para reconocer al ligando, complejo que incluye las proteínas CD14 (Cluster of Differentiation 14), la proteína soluble de unión al lipopolisacárido (LBP, Lipopolysaccharide Binding Protein), y la proteína de señalización MD-2 (Myeloid Differentiation Protein-2). El complejo LPS-LBP-CD14 presenta el LPS bacteriano a MD-2, que se une a TLR4 (Figura 2) para activar la señalización e inducir la producción de mediadores proinflamatorios (Janeway y Medzhitov, 2002; Underhill y Ozinsky, 2002a; Underhill, 2004; Aderem y Ulevitch, 2000; Underhill y Goodridge, 2012).

Hay que destacar que la señalización vía TLR2 y TLR4 es necesaria para la maduración de los fagosomas que contienen bacterias (Blander y Medzhitov, 2004). 


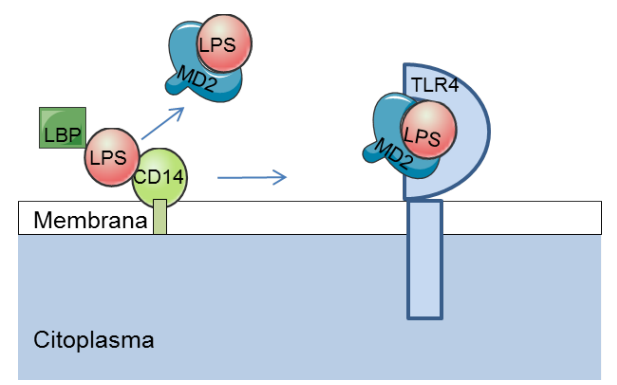

Figura 2. Ensamblaje del complejo TLR4-MD2-LPS. La proteína CD14 está anclada a la membrana celular por el glicosilfosfatidilinositol, pero carece de dominio citoplasmático. Imagen de elaboración propia.

\section{- Receptores scavenger (SR)}

Varios receptores scavenger (SR) se expresan en macrófagos y células dendríticas, y median la fagocitosis no opsónica de microorganismos como S.aureus, E.coli, Streptococcus pneumoniae y Neisseria meningitidis. Los SR son capaces de unirse directamente a los microorganismos, se localizan en la superficie celular y se dividen en 8 tipos diferentes $(\mathrm{A}-\mathrm{H})$ en función de su estructura molecular. En la tabla 3 se especifican los ligandos del receptor scavenger A (SR-A); del receptor de macrófagos con estructura colagenasa denominado MARCO (SR de tipo A); del receptor SRCL-I (o CL-PI, SR de tipo A); del receptor SCARA5 (SR de tipo A); del receptor CLA-1 (SR de tipo $B$ ); y del receptor CD36 (SR de tipo B) que se asocia con heterodímeros TLR2/6 en la superficie celular, y esta interacción produce la señalización para reconocer a S.aureus y M.tuberculosis (Gordon, 2016; Triantafilou et al., 2006; Underhill y Ozinsky, 2002a; Areschoug y Gordon, 2009).

\section{- Receptores de lectina tipo-C (CLRs)}

Los receptores no opsónicos lectina tipo $\mathrm{C}$ se caracterizan por la presencia de un dominio común de lectina tipo-C (CTLD, C-Type Lectin-Like Domains) de reconocimiento de carbohidratos. La activación de estos receptores conduce a una señalización intracelular a través de vías dependientes o independientes de Syk (Spleen tyrosine kinase). En la tabla 3 se especifican los ligandos de algunos de los receptores que se detallan a continuación. Entre las lectinas de membrana destacamos el receptor de manosa (MR, Mannose Receptor; ó CD206, Cluster of Differentiation 206), que se expresa principalmente en células dendríticas y macrófagos, y es capaz de reconocer M.tuberculosis, Streptococcus pneumoniae, Candida albicans, entre otros microorganismos. DC-SIGN (Dendritic Cell-Specific ICAM-3-Grabbing Non integrin) reconoce patógenos a través de estructuras con alto contenido en manosa y fucosa. Dectin-1 (también denominado CLEC7a) reconoce Candida albicans gracias a su 
dominio de tipo lectina y posee un motivo ITAM (Immunoreceptor Tyrosine-based Activation Motif) en su parte citoplásmica, lo que permite su asociación a Syk y CARD9 (Caspase Recruitment Domain 9). Dectin-2 (ó CLEC6a) se expresa en macrófagos tisulares, células dendríticas y monocitos, y reconoce Candida albicans. A diferencia de Dectin-1, la unión al ligando depende de calcio. Para iniciar el proceso de señalización intracelular precisa unirse a moléculas adaptadoras con motivos ITAM como la cadena $\gamma$ del receptor Fc, ya que Dectin-2 presenta una cola citoplasmática corta sin motivos de señalización. Además, se ha demostrado que Dectin-1 y Dectin-2 median la fagocitosis de levaduras y zymosán, junto con los receptores TLR2, TLR6. El receptor Mincle (denominado también CLEC4E) se asocia a Fc $\gamma$ para inducir señales intracelulares a través de Syk, CARD9 y MAPK, produciendo citoquinas y quimioquinas (TNF, CXCL2, CXCL1 e IL-6); además este receptor puede colaborar con los receptores TLR (Underhill y Ozinsky, 2002b; Gordon, 2002; Herre et al., 2004; West et al., 2011b; Brown, 2006; Dambuza y Brown, 2015; Takeuchi y Akira, 2010).

Tabla 3. Receptores fagocíticos. Se representan con fondo gris claro los receptores opsónicos y con fondo gris oscuro los receptores no opsónicos.

\begin{tabular}{|c|c|c|}
\hline Receptores & $\begin{array}{l}\text { Tipo de } \\
\text { receptor }\end{array}$ & Ligandos \\
\hline $\mathrm{FcR}(\mathrm{Fc} \gamma \mathrm{Rs})$ & FcR & Partículas opsonizadas con anticuerpos \\
\hline CR1 & $\mathrm{CR}$ & MBL, C1q, C4b, C3b-partículas opsonizadas \\
\hline CR3 & CR & iC3b-partículas opsonizadas \\
\hline CR4 & CR & iC3b-partículas opsonizadas \\
\hline MR & CLR & $\alpha$-mananos, D-manosa, L-fucosa, y N-acetil-D-glucosamina \\
\hline DC-SIGN & CLR & Manosa, fucosa \\
\hline Dectin-1 & CLR & $\beta(1-3)$ glucanos \\
\hline Dectin-2 & CLR & Manosa \\
\hline SRA & SR & LPS, LTA \\
\hline CD36 & SR & LTA, lipopéptido MALP \\
\hline CLA-1 & SR & $\begin{array}{c}\text { Bacterias Gram positivas (S.aureus, L. monocytogenes) y Gram negativas (E.coli, } \\
\text { S.typhimurirum) }\end{array}$ \\
\hline SRCL-I & SR & E.coli, S.aureus inactivadas por calor, S.cerevisae \\
\hline SCARA5 & SR & E.coli, S.aureus inactivadas por calor \\
\hline MARCO & SR & $\begin{array}{l}\text { Bacterias (sin definir ligando especifico), S.pneumoniae y } \\
\text { N.meningitidis, partículas inertes (látex) }\end{array}$ \\
\hline NOD1 & $\begin{array}{l}\text { Citosólico } \\
\text { (NLR) }\end{array}$ & Ácido D-glutamil-mesodiaminopimelico \\
\hline NOD2 & $\begin{array}{l}\text { Citosólico } \\
\text { (NLR) }\end{array}$ & Muramil dipéptido (MDP), ssRNA de virus \\
\hline
\end{tabular}




\section{- Receptores citosólicos}

Los principales receptores localizados en el citoplasma son NLRs y RLRs.

Los NLRs reconocen componentes microbianos intracelulares y peptidoglicanos bacterianos, y también se unen a nucleótidos. Contienen dominios de reclutamiento de caspasa en el extremo N-terminal (CARD ó PYD) que regula la transducción de señales a través de interacciones proteína-proteína; un dominio central NATCH (único dominio común a todos los miembros de la familia NLR) que regula la auto-oligomerización; y un dominio LRR C-terminal que se encarga del reconocimiento del ligando. Algunos miembros de la familia NLR más conocidos en los macrófagos son el receptor NOD1 que contiene el dominio CARD4, y el receptor NOD2 contiene el dominio CARD15. En la tabla 3 se especifican los ligandos que reconocen. Cuando los ligandos activan NOD1 y NOD2, la transducción de señales de estos receptores se realiza a través de RIP2 (Receptor-interacting serine-threonine kinase 2) con interacciones CARD-CARD (Caspase Recruitment Domains) para activar NF-к $\beta$ y MAPK, lo que resulta en la producción de citoquinas.

Los RLRs son helicasas de RNA que reconocen RNA bicatenario (dsRNA) de virus y responden generando IFNs de tipo I. Los RLRs utilizan IPS-1 (IFN-beta Promoter Stimulator 1) y TRAF6 (TNF Receptor-Associated Factor 6) como moléculas adaptadoras. Se han identificado algunos RLR como: RIG-1 (Retinoic acid inducible gene 1 , conocido también como DDX58) que reconoce el virus de la gripe y MDA5 (Melanoma Differentiation Associated factor 5, conocido también como IFIH1) que reconoce el virus de la familia Picornaviridae. RIG-1 y MDA5 contienen un dominio de reclutamiento de caspasa (CARD) y un dominio de RNA helicasa (Jeong et al., 2011; Zhang y Wang, 2014; Kawai y Akira, 2011; Schroder y Tschopp, 2010).

\subsubsection{Receptores de reconocimiento opsónicos}

Aunque los PRRs tienen un papel fundamental en el reconocimiento y la adherencia de los microorganismos a la superficie de los fagocitos, la eficiencia de la fagocitosis se encuentra aumentada si los microorganismos están previamente revestidos con los anticuerpos específicos o con diversas fracciones del complemento. Este proceso por el cual los antígenos particulados unen los anticuerpos específicos o el complemento (opsoninas) se denomina opsonización. Los receptores fagocíticos opsónicos mejor caracterizados son varios receptores del complemento (CR, Complement Receptor) y los receptores Fc (FcR, Fc-gamma Receptors).

Hay tres familias descritas de receptores del complemento: (i) los módulos de repetición corta (SCR) que codifican CR1 (CD35) y CR2 (CD21), (ii) los miembros de la 
familia de integrinas $\beta 2$ CR3 (CD11b/CD18) y CR4 (CD11c/CD18), y (iii) CRIg (receptor del complemento de la superfamilia de las inmunoglobulinas) (Rosales y Uribe-Querol, 2017; van Lookeren Campagne et al., 2007). CR1 se une a un amplio espectro de opsoninas microbianas incluyendo componentes del complemento C1q, C4b y C3b, así como a la lectina de unión a manosa (MBL, Mannose Binding Lectin). Los monocitos y macrófagos expresan una variedad amplia de receptores del complemento que incluyen los receptores 1,3 y 4 (CR1, CR3 y CR4, respectivamente), los cuales requieren de receptores adicionales (como el receptor $\mathrm{Fc}$ ) para mediar la internalización de las partículas opsonizadas por el complemento. Las citoquinas inflamatorias, como TNF $\alpha$, componentes microbianos, como LPS, y de adhesión, como fibronectina, estimulan la fagocitosis a través del CR3 (Underhill y Ozinsky, 2002b).

Los receptores FcyRs son glicoproteínas expresadas en la membrana de los fagocitos, capaces de unirse a la región Fc de las inmunoglobulinas (lgG), mientras que los FcaRs se unen a los anticuerpos IgA (Rosales y Uribe-Querol, 2017). Los fagocitos expresan combinaciones diferentes de FcRs: a) receptores que contienen motivos ITAM en los dominios intracelulares que reclutan quinasas y activan cascadas de fosforilación, y b) receptores que contienen motivos ITIM (Immunoreceptor Tyrosine-based Inhibitory Motifs) que reclutan fosfatasas que inhiben la señalización (Underhill y Ozinsky, 2002b).

\subsubsection{Internalización}

Tras el reconocimiento de la partícula por el receptor aumentan los niveles del fosfolípido $\mathrm{PI}(4,5) \mathrm{P}_{2}$ (Phosphatidylinositol 4,5-biphosphate), y se induce la formación de los pseudópodos para formar la "copa fagocítica" y englobar la partícula fagocitada. Se activan los receptores presentes en la membrana citoplasmática, las GTPasas (Guanosine Triphosphatases) pertenecientes a la familia Rho (Ras homologous). La familia Rho incluye 23 miembros, siendo tres de ellos muy importantes Rac1, Rac2 y Cdc42, que se activan para la formación del fagosoma a través de enzimas como PI3K (Phosphoinositide 3-Kinase). Cdc42 y Rac1 activan las proteínas involucradas en la polimerización y ramificación de los filamentos de actina (F-actina), como WASp (Wiskott-Aldrich Syndrome Protein) y Scar/WAVE respectivamente. WASp y Scar activan el complejo Arp2/3 (Actin-Related Protein 2/3 complex), y de esta forma permiten la extensión de los pseudópodos para englobar la partícula (Marie-Anaïs et al., 2016; Schlam et al., 2015; Marchand et al., 2001). En los macrófagos, Rac1 induce la formación de prolongaciones aplanadas transitorias, llamadas lamelipodios, mientras que Cdc42 induce la formación de filopodios, que son proyecciones citoplasmáticas delgadas. Los lamelipodios y filopodios permiten romper los enlaces que anclan a la 
bacteria a la superficie de sustrato facilitando su internalización (Mao y Finnemann, 2015).

\subsubsection{Formación del fagosoma}

En la formación del fagosoma el mecanismo de polimerización y despolimerización de F-actina está controlado por fosfatidilinositoles, en particular $\mathrm{PI}(3,4,5) \mathrm{P}_{3}$. Cuando $\mathrm{PI}(4,5) \mathrm{P}_{2}$ se fosforila por $\mathrm{PI} 3 \mathrm{~K}$, produce $\mathrm{PI}(3,4,5) \mathrm{P}_{3}$ en la "copa fagocítica" para facilitar la despolimerización de actina y el cierre del fagosoma. En esta fase se reduce la polimerización de actina, por la liberación de las proteínas cofilina y gelsolina, y por la inhibición de WASp. Otras moléculas reguladas por $\mathrm{PI}(3,4,5) \mathrm{P}_{3}$ son las miosinas que tienen una actividad contráctil y facilitan el cierre del fagosoma (Cox et al., 2002). La proteína dinamina-2, también aumenta en el cierre del fagosoma, y su función es mediar la escisión de las vesículas endocíticas y la despolimerización de actina (Marie-Anäis et al., 2016).

\subsubsection{Maduración del fagosoma}

Tras la escisión de la membrana plasmática y la formación del fagosoma, se produce la maduración del fagosoma. En este proceso de transformación se llevan a cabo interacciones de fusión y fisión entre el nuevo fagosoma y los endosomas tempranos, los endosomas tardíos y finalmente con los lisosomas. La maduración del fagosoma se divide en cuatro etapas: fagosoma temprano, fagosoma intermedio, fagosoma tardío y fagolisosoma (Figura 3). Éste último es una vesícula que tiene una composición de membrana diferente, muy ácida y de alta capacidad degradativa, que puede destruir al microorganismo ingerido (Canton, 2014). Los lisosomas contienen enzimas hidrolíticas, que con la fusión fagolisosomal, se vierten en el fagosoma originando la destrucción y la digestión del microorganismo. En los macrófagos, la unión y la fusión fagolisosomal es dependiente de calcio, debido a que este ion está relacionado con un aumento en la polimerización de actina, mientras que la formación de los fagosomas tempranos y tardíos no requieren de calcio (Nunes et al., 2010).

El fagosoma temprano tiene lugar con la fusión de la membrana entre el fagosoma y los endosomas tempranos, y está regulado por la GTPasa Rab5, que recluta la proteína EEA1 (Early Endosome Antigen 1). EEA1 se une a syntaxina 13, una proteína SNARE (Soluble N-ethylmaleimide-sensitive factor-Attachment protein Receptor) que se necesita para la fusión de la membrana (Vieira et al., 2002; Weiss y Schaible, 2015; Pauwels et al., 2017). A medida que avanza la maduración, en el fagosoma intermedio, desaparece Rab5, y Rab7 aparece en la membrana. Esta transición está mediada por el complejo HOPS (vpsC-Homo-typic Protein-Sorting). La 
degradación de proteínas de membrana requiere el transporte del complejo ESCRT (Endosomal Sorting Complexes Required for Transport) (Hanson et al., 2008; Rosales y Uribe-Querol, 2017). Tras la eliminación de las proteínas por degradación o reciclaje en el fagosoma intermedio, la maduración continúa en el fagosoma tardío. El marcador de esta fase es la acumulación de Rab7, que media la fusión del fagosoma con los endosomas tardíos. Además, Rab7 recluta nuevas proteínas en la membrana como es RILP (Rab-Interacting Lysosomal Protein), lo que permite el movimiento centrípeto de los fagosomas tardíos y lisosomas. Las proteínas de membrana asociadas a lisosomas (LAMPs, Lysosomal-Associated Membrane Protein) y las proteasas luminales (catepsinas e hidrolasas) se incorporan a la fusión con endosomas tardíos (Huynh et al., 2007; Rosales y Uribe-Querol, 2017). La última etapa es la fusión del fagosoma tardío con lisosomas, para dar lugar al fagolisosoma. La ATPasa vacuolar (V-ATPasa) se recluta acidificando la luz fagosomal mediante el bombeo interno de protones y degradando la partícula. Los fagolisosomas se caracterizan por la ausencia de receptores manosa-6-fosfato (marcador endosomal tardío), y se acumulan las enzimas degradativas como catepsinas, lisozimas, proteasas y lipasas que destruyen a los microorganismos.

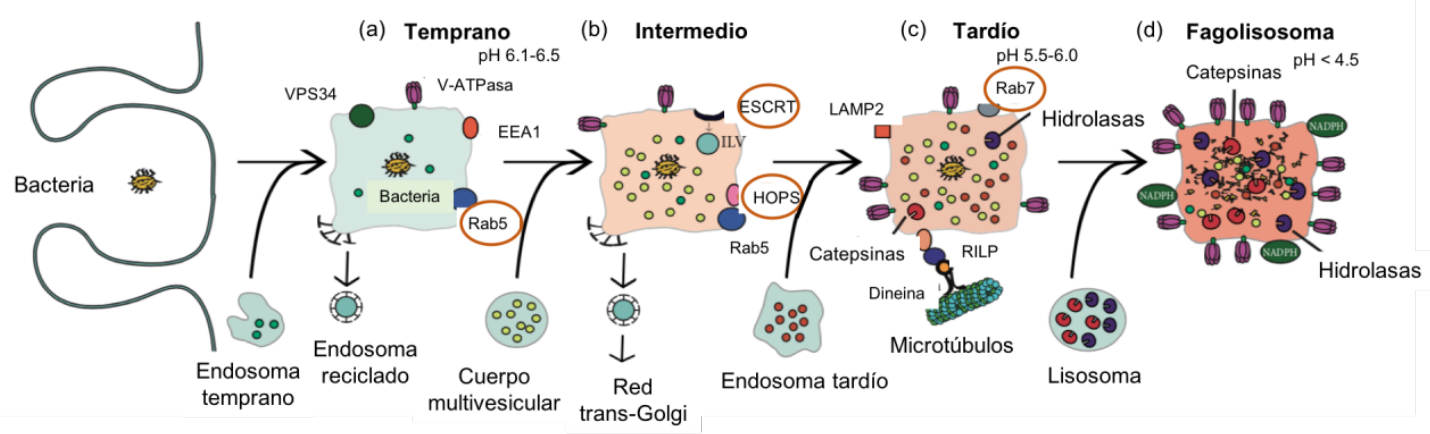

Figura 3. Maduración del fagosoma. Cuatro etapas de maduración: temprano, intermedio, tardío y fagolisosoma. El fagosoma temprano se transforma en una vacuola microbicida, el fagolisosoma, por interacciones secuenciales con vesículas de la vía endocítica. En este proceso, el fagosoma se vuelve cada vez más ácido por la acción de una ATPasa que bombea protones y obtiene diversas enzimas de degradación. La composición de la membrana cambia, como las moléculas GTPasas que controlan la fusión de la membrana. Imagen modificada de Rosales y Uribe-Querol, 2017. EEA1, antígeno endosómico temprano 1; ESCRT, complejo de clasificación endosomal requerido para el transporte; HOPS, complejo de fusión homotípica y organización vacuolar; ILV, vesícula intraluminal; LAMP, proteína de membrana asociada a lisosomas; NADPH, nicotinamida adenina dinucleótido fosfato oxidasa; RILP, proteína lisosómica que interactúa con Rab; vPS34, clasificación de proteínas vacuolares 34. 


\subsection{Mecanismos microbicidas}

Los mecanismos microbicidas pueden ser independientes o dependientes del oxígeno.

\section{- Mecanismos microbicidas independientes del oxígeno}

Los fagocitos median la actividad lítica de los microorganismos mediante una amplia variedad de mecanismos, entre los que se encuentran, como ya hemos mencionado, la acidificación del fagosoma que ocurre mediante la formación de un gradiente de iones $\mathrm{H}^{+}$por la ATPasa de su membrana. La acidificación tiene actividad microbicida directa y facilita la acción de enzimas que funcionan de forma óptima a pH ácido (Male et al., 2013).

Los macrófagos activados también sintetizan varias enzimas hidrolíticas, como las lisozimas, que no requieren oxígeno e hidrolizan los enlaces glicosídicos $\beta(1-4)$ que forman los principales componentes estructurales de macromoléculas como el peptidoglicano. Además, producen un grupo de péptidos antimicrobianos y citotóxicos que se conocen como defensinas. Estas moléculas son péptidos catiónicos ricos en cisteína que contienen de 29 a 35 residuos de aminoácidos, que forman los canales permeables a iones en membranas de la célula bacteriana, destruyendo de esta forma a bacterias como S.aureus y E.coli al crear un desequilibrio osmótico (Male et al., 2013; Flannagan et al., 2012).

Otro mecanismo microbicida de los fagolisosomas es el secuestro de nutrientes esenciales por la lactoferrina, que captura $\mathrm{Fe}^{2+}$ elemento, esencial para el crecimiento de algunas bacterias. El transportador de membrana presente en fagolisosomas NRAMP-1 (Natural Resistance-Associated Macrophage Protein 1; también conocido como SLC11A1, Solute Carrier Family 11 Member 1) exporta los iones $\mathrm{Fe}^{2+}, \mathrm{Zn}^{2+}$ y $\mathrm{Mn}^{2+}$ fuera del fagolisosoma previniendo así el crecimiento microbiano (Male et al., 2013; Uribe-Querol y Rosales, 2017).

\section{- Mecanismos microbicidas dependientes de oxígeno}

Los mecanismos microbicidas dependientes de oxígeno constituyen el principal mecanismo bactericida de las células fagocíticas. Se produce la liberación de ROS y RNS, los cuales actúan directamente sobre los microorganismos o bien mediante la activación de diversos sistemas enzimáticos. Los radicales libres son especies químicas que poseen un electrón desapareado en su orbital más externo, y participan en la defensa frente a microorganismos, en la señalización celular, en el mantenimiento del equilibrio de óxido-reducción y en la activación de las GTPasas. Los radicales libres del oxígeno se producen en la membrana plasmática y otros compartimentos intracelulares, 
proceso catalizado por enzimas como la NADPH oxidasa (NOX), la xantina oxidasa, la citocromo $\mathrm{c}$ reductasa, y en la cadena respiratoria mitocondrial.

Durante la fagocitosis tiene lugar en los macrófagos activados un proceso metabólico que se conoce como "explosión oxidativa", que consiste en la acumulación de los radicales reactivos de oxígeno generados por la reducción parcial del oxígeno molecular que da lugar a los aniones superóxido $\left(\mathrm{O}_{2}{ }^{-}\right)$, el peróxido de hidrógeno $\left(\mathrm{H}_{2} \mathrm{O}_{2}\right)$ y el oxígeno singlete. En la explosión oxidativa se activa la oxidasa unida a la membrana del fagosoma, NADPH oxidasa (NOX2), generando ROS al catalizar la reducción del oxígeno $\left(\mathrm{O}_{2}\right)$ en superóxido $\left(\mathrm{O}_{2}{ }^{-}\right)$. Éste último es un compuesto tóxico para los microorganismos ingeridos al interferir con los sistemas respiratorios de los microorganismos. La superóxido dismutasa (SOD) convierte el superóxido en radicales hidroxilo $(\mathrm{OH})$ y peróxido de hidrógeno $\left(\mathrm{H}_{2} \mathrm{O}_{2}\right)$; éste último puede eliminar los microorganismos, y es convertido por otras enzimas en hipoclorito $\left(\mathrm{OCl}^{-}\right)$y radical hidroxilo $(\mathrm{OH})$. Además, las enzimas peroxidasas, como la mieloperoxidasa (MPO), en presencia del peróxido de hidrógeno $\left(\mathrm{H}_{2} \mathrm{O}_{2}\right)$ e iones cloruro $\left(\mathrm{Cl}^{-}\right)$genera ácido hipocloroso y cloraminas, altamente tóxicos para las bacterias (Levin et al., 2016; Flannagan et al., 2012).

Los radicales libres de nitrógeno (RNS) se producen a partir de la conversión de L-arginina y oxígeno en L-citrulina a través de la enzima óxido-nítrico sintasa inducible (NOS2 o iNOS) formando óxido nítrico que se transforma en peroxinitrato al reaccionar con ROS. Los RNS inactivan las enzimas que contienen hierro y azufre, y dañan el DNA. Los ROS y los RNS pueden interaccionar para producir peroxinitritos, y estas especies reactivas actúan dentro del fagosoma para provocar efectos tóxicos sobre los microorganismos que contienen; también interaccionan con tioles y tirosinas, dañando los ácidos nucleicos, lípidos de membrana y proteínas. De esta forma se ven afectados el metabolismo y la replicación bacterianos.

Los ROS también se producen en la cadena respiratoria mitocondrial. La generación mitocondrial de ROS (mitoROS) es consecuencia de la fosforilación oxidativa, proceso por el cual se genera energía y los electrones derivados de la oxidación del NADH y $\mathrm{FADH}_{2}$ pueden reaccionar directamente con oxígeno y generar mitoROS. Los complejos I y III son las principales fuentes de producción de mitoROS. El complejo I produce $\mathrm{O}_{2}^{-}$cuando el ratio $\mathrm{NADH} / \mathrm{NAD}^{+}$es alto y en presencia de inhibidores, como la rotenona, que interaccionan en el sitio de unión de la ubiquinona. También se puede producir $\mathrm{O}_{2}{ }^{-}$cuando la ubiquinona se encuentra reducida (ubiquinol), el potencial de membrana es alto, y el transporte de electrones ocurre desde el ubiquinol hacia el complejo I (conocido como transporte de electrones reverso); se reduce así el 
$\mathrm{NAD}^{+}$en $\mathrm{NADH}$ y se genera $\mathrm{O}_{2}^{-}$. En el complejo III se produce $\mathrm{O}_{2}^{-}$cuando se inhibe con la antimicina A (Murphy, 2009; Bleier y Dröse, 2013; Lenaz et al., 2006).

\section{La mitocondria en el sistema inmunitario innato}

La mitocondria es un orgánulo esencial para la función celular, incluyendo la generación celular de la energía en forma de ATP a través de la fosforilación oxidativa (OXPHOS) y la oxidación de metabolitos (ciclo de Krebs o ciclo del ácido cítrico y $\beta$ oxidación de ácidos grasos). También es importante en la modulación de la apoptosis celular y los procesos de envejecimiento (Chen et al., 2012), así como en la inmunidad innata y la inflamación (Droge, 2002; Stanley et al., 2014; Weinberg et al., 2015), la producción de ROS, el mantenimiento de la homeostasis intracelular de calcio $\left(\mathrm{Ca}^{2+}\right)$ y procesos metabólicos específicos, como la biosíntesis de colesterol o la producción de hormonas (particularmente la pregnenolona, que actúa como precursora de las hormonas esteroides, como por ejemplo la progesterona) (Cloonan y Choi, 2016; Pellegrino y Haynes, 2015).

La disfunción mitocondrial se asocia con diversas enfermedades, incluyendo el cáncer, trastornos metabólicos y enfermedades neurodegenerativas, como el Alzheimer, el Parkinson y la enfermedad de Huntington, entre otras (He et al., 2013; Chen et al., 2012; Hendrickson et al., 2010).

\subsection{Estructura y composición de la mitocondria}

La forma y número de mitocondrias por célula depende de los requerimientos energéticos celulares. Son orgánulos compuestos de dos membranas: la membrana mitocondrial externa, que separa el espacio intermembrana del citosol y debido a su porosidad carece de potencial de membrana, y la membrana mitocondrial interna, que separa la matriz mitocondrial del espacio intermembrana. La membrana interna presenta una serie de invaginaciones, denominadas crestas que proporcionan una gran superficie, las cuales contienen la mayoría de los complejos de la cadena respiratoria, y es donde tiene lugar la fosforilación oxidativa. El compartimento más interno, rodeado por la membrana interna, es la matriz mitocondrial, y es el sitio de replicación del DNA, la transcripción, la biosíntesis de proteínas y numerosas reacciones enzimáticas, como la oxidación de los aminoácidos; también aquí se localizan algunas reacciones de la síntesis de urea y de los grupos hemo. La matriz tiene un $\mathrm{pH}$ alto y crea un gradiente electroquímico transmembrana que conduce a la síntesis de ATP. Es en la matriz donde se encuentran las enzimas del ciclo del ácido cítrico (TCA, Tricarboxylic Acid Cycle) y de la $\beta$-oxidación de los ácidos grasos, el genoma mitocondrial y los ribosomas mitocondriales (Kühlbrandt, 2015; Mishra y Chan, 2014). 


\subsection{La cadena respiratoria mitocondrial y la fosforilación oxidativa}

La fosforilación oxidativa (OXPHOS) comienza cuando los equivalentes de reducción NADH y $\mathrm{FADH}_{2}$ obtenidos por la descarboxilación del piruvato, $\beta$-oxidación de ácidos grasos y en el ciclo de Krebs se oxidan por las enzimas de la cadena de transporte de electrones con la consiguiente obtención de energía y oxígeno. Dicha energía se utiliza para bombear protones hacia el exterior de la matriz mitocondrial constituyendo así un gradiente de protones (potencial de membrana) a ambos lados de la membrana interna mitocondrial, que se utiliza por la ATP-sintasa (complejo V) para generar ATP. En este proceso intervienen cinco complejos enzimáticos (I-V) entre los que se sitúan dos transportadores móviles: coenzima $Q$ y citocromo $C$ (Figura 4). La translocasa ATP-ADP exporta el ATP hacia el espacio intermembrana, donde se difunde libremente fuera de la membrana externa hacia el citosol (Mishra y Chan, 2014).

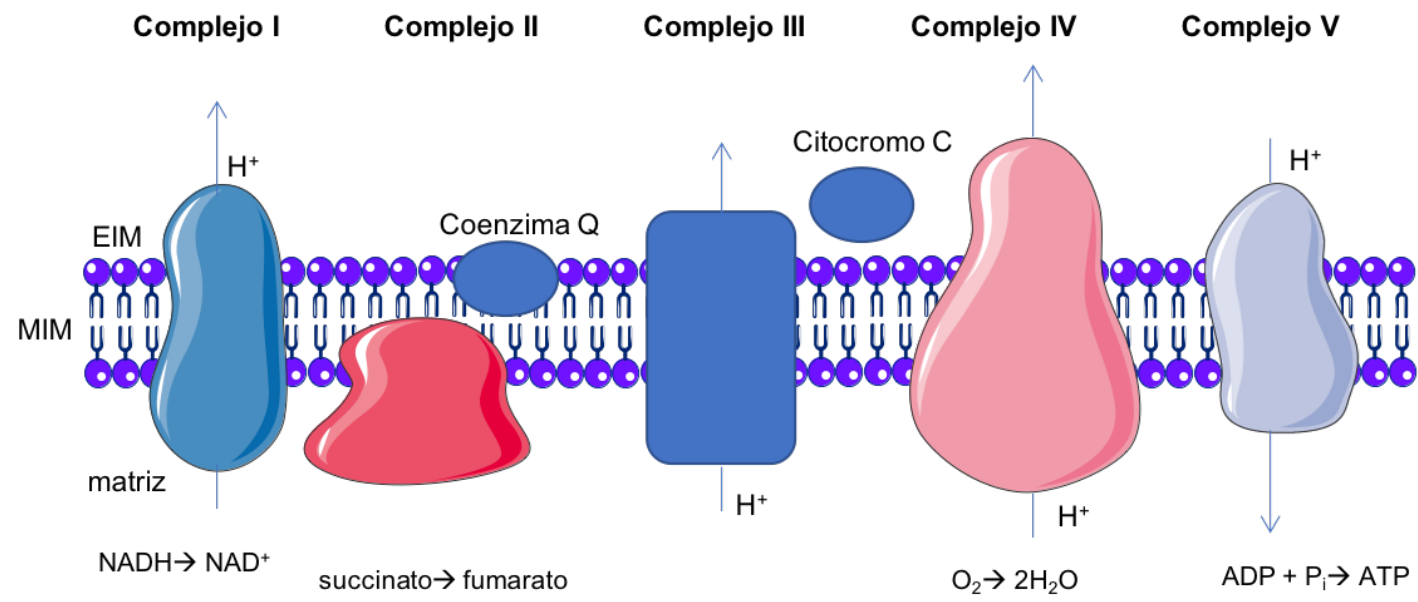

Figura 4. Complejos mitocondriales en la fosforilación oxidativa. Esquema del complejo I al $\mathrm{V}$, se representa la generación del gradiente de protones y la producción de agua y energía. EIM (espacio intermembrana); MIM (membrana interna mitocondrial). Figura de elaboración propia.

- El complejo I ( $\mathrm{Cl}, \mathrm{NADH}$ deshidrogenasa), es el complejo enzimático más grande de la cadena transportadora de electrones (entre 800-900 KDa). Presenta una estructura en forma de "L", con un brazo hidrofílico que contiene la subunidad de unión al NADH y el centro activo de la enzima, constituido por una flavina y 9 centros hierrosulfurados y una región hidrofóbica perpendicular a él (Hoefs et al., 2012). Cataliza la primera etapa de transferencia de electrones desde el NADH a la ubiquinona o coenzima $\mathrm{Q}(\mathrm{CoQ})$, una molécula liposoluble que al reducirse se transforma en ubiquinol $\mathrm{QH}_{2}$. Así que se transfieren dos electrones desde el NADH a la CoQ y cuatro protones son bombeados al espacio intermembrana, generándose así un gradiente de protones (Andrews et al., 2013). Este proceso supone cerca del $40 \%$ del gradiente de protones transmembrana generado en la oxidación del NADH (Herrero y Barja, 2000). La NADH 
deshidrogenasa es un polipéptido compuesto, en mamíferos, por 45 subunidades, de las cuales, catorce son esenciales para la catálisis: NDUFS1, NDUFS2, NDUFS3, NDUFS6, NDUFS7, NDUFS8, NDUFV1-2, MTND1-6 y MTND4L. Mientras que el resto participan en la biogénesis del complejo, la estabilidad estructural, la regulación o protección frente al estrés oxidativo (Vinothkumar et al., 2014; Zhu et al., 2016; Blaza et al., 2018).

- El complejo II (CII, succinato deshidrogenasa; succinato-ubiquinona reductasa), cataliza la reacción de oxidación de succinato a fumarato formando $\mathrm{FADH}_{2}$, que se oxida in situ y cede los electrones a CoQ. Este complejo se compone de 4 péptidos todos ellos codificados en el genoma nuclear. El complejo II representa el punto de encuentro entre el ciclo de Krebs y la cadena de transporte de electrones mitocondrial. Es el único complejo que no participa en la generación del potencial de membrana, no es una bomba de protones, por ello se genera menos ATP en la oxidación del FADH 2 que en la del NADH (Dröse, 2013; Grimm, 2013). La coenzima Q, actúa como lanzadera de electrones desde los complejos I y II al complejo III.

- El complejo III (CIII, ubiquinol:citocromo c oxidorreductasa), presenta una estructura dimérica, está compuesto por 11 subunidades, 3 grupos hemos y un centro Fe-S. Se cataliza aquí la transferencia de electrones desde el ubiquinol o $\mathrm{CoQ}$ al citocromo c, que se encuentra en el espacio intermembrana mitocondrial, y es el aceptor final de los electrones, generando un bombeo de 2 protones hacia el espacio intermembrana, por cada par de electrones transferidos (Bleier y Dröse, 2013).

- El complejo IV (CIV, citocromo c oxidasa), bombea cuatro protones al espacio intermembrana. Tiene 13 subunidades y cataliza la transferencia de cuatro electrones del citocromo c a una molécula de oxígeno, dando lugar a 2 moléculas de $\mathrm{H}_{2} \mathrm{O}$ ( $\mathrm{Li}$ et al., 2006).

- El complejo V (F0-F1 ATPasa ó ATP sintasa), es el responsable de la síntesis de ATP a partir de difosfato de adenosina (ADP), un grupo fosfato (Pi) y la energía suministrada por el gradiente de protones. Por cada 3 protones que fluyen a través del complejo se forma una molécula de ATP. El complejo está formado por 16 proteínas diferentes, que forman dos complejos denominados F0 y F1, conectados entre sí. El componente F1 se localiza en la matriz mitocondrial constituyendo la porción soluble de la enzima y se compone de cinco subunidades distintas, que forman el dominio catalítico de la ATP sintasa. La región FO se encuentra anclada en la membrana interna mitocondrial, es un complejo hidrofóbico y forma el canal de protones. 


\subsection{Metabolismo mitocondrial y señalización de la inmunidad innata}

El metabolismo mitocondrial regula la transcripción, la producción de citoquinas, la polarización de los macrófagos y la fagocitosis. En los últimos años se han descrito datos que relacionan la respuesta inmunitaria innata y las funciones metabólicas mitocondriales, y sugieren que la mayoría de los agonistas para los PRRs producen adaptaciones metabólicas. En respuesta a la señalización de estos receptores, la cadena respiratoria mitocondrial tiene la capacidad de ajustar su arquitectura y actividad induciendo cambios en los flujos metabólicos, el balance redox y los metabolitos intermediarios.

\section{- Adaptaciones de la cadena respiratoria mitocondrial a la exposición} bacteriana: producción de citoquinas, fagocitosis y acción bactericida

La mitocondria es clave para la generación de citoquinas y metabolitos que favorecen la respuesta inmunitaria innata. Por un lado, se ha descrito que la inhibición por métodos genéticos de la subunidad del $\mathrm{Cl}$, NDUFS4, promueve la polarización de los macrófagos hacia un fenotipo proinflamatorio M1 (Jin et al., 2014). Por el contrario, la inhibición farmacológica del $\mathrm{Cl}$ en los macrófagos, con rotenona y metformina, disminuye la secreción de la citoquina proinflamatoria IL-1 $1 \beta$ en presencia de LPS y aumenta la secreción de la citoquina antiinflamatoria IL-10 (Kelly et al., 2015). Estos datos aparentemente contradictorios revelen el papel del $\mathrm{Cl}$ en el fino balance entre el estado pro- y antiinflamatorio. Se conoce que la reducción de la actividad del $\mathrm{Cl}$ en los macrófagos activados produce un aumento de la actividad del Cll, y se ha propuesto que este aumento se requiere para la generación de citoquinas proinflamatorias (Garaude et al., 2016). En este sentido se ha descrito que la inhibición del Cll mediante el uso del ácido 3-nitropropiónico y de dimetilmalonato, produce un aumento en la secreción de la citoquina antiinflamatoria IL-10 y una disminución en la secreción de las citoquinas proinflamatorias IL-1 y TNF $\alpha$ (Garaude et al., 2016). Sin embargo, el succinato, sustrato del Cll, produce la inhibición en la inducción de las citoquinas antiinflamatorias como IL-10 y un aumento en la inducción de IL-1 $\beta$ a través de la activación del factor de transcripción HIF-1 $\alpha$ (hypoxia-inducible factor $1 \alpha$ ), y también se producen mitoROS (Mills y O'Neill, 2014; Mills et al., 2016). Se ha demostrado que el itaconato, metabolito que se genera a partir de citrato, por la enzima cis aconitato descarboxilasa, codificada por la proteína Irg1 (Immunoresponsive Gene 1), inhibe la succinato deshidrogenasa (SDH, Succinate Dehydrogenase) y activa el factor de transcripción antiinflamatorio Nrf2 (Nuclear Factor like 2), aumentando así la expresión de genes con capacidades antiinflamatorias y antioxidantes. Ya que los macrófagos Irg1 $\mathrm{KO}$ no producen itaconato, tienen niveles reducidos de succinato y un aumento de la 
respiración mitocondrial y la producción de citoquinas tras la estimulación con LPS (Mills et al., 2018) (Figura 5). Los IFNs inducen la acumulación de Irg1 en las mitocondrias y es necesario para eliminar las bacterias, como Legionella (Naujoks et al., 2016). Tomados en conjunto, estos estudios sugieren que la manipulación de la cadena transportadora de electrones modula el equilibrio entre la producción de citoquinas proinflamatorias y antiinflamatorias, a pesar de las aparentes contradicciones halladas en la literatura descrita.

Cada vez hay más evidencias que indican que el reconocimiento de bacterias Gram negativas y la exposición a los ligandos de TLR4 por los macrófagos disminuye OXPHOS y aumenta la glucólisis (Tannahill et al., 2013; Lachmandas et al. 2016; Rodríguez-Prados et al., 2010; O’Neill y Pearce, 2016). En los monocitos humanos, y en las células dendríticas, estimulados con P3C (Pam3CysSK4) que activan TLR2, aumenta el consumo de oxígeno y la actividad enzimática mitocondrial (Lachmandas et al., 2016).

Los complejos respiratorios (Cl/ III/ IV ó Cl/ III ó CII/ IV) pueden ensamblarse en supercomplejos. Los supercomplejos organizan el flujo de electrones para optimizar el sustrato disponible que se requiere para la síntesis de ATP y el consumo de oxígeno (Lapuente-Brun et al., 2013; Enríquez et al., 2016). La acumulación de los intermediarios del ciclo TCA puede contribuir directamente a las funciones antibacterianas de los macrófagos. Por ejemplo, los macrófagos estimulados con LPS acumulan citrato, que puede ser metabolizado a ácido itacónico provocando efectos antibacterianos frente a varios patógenos como Salmonella enterica Typhimurium o Legionella pneumophila (Michelucci et al., 2013; Naujoks et al., 2016). La activación de PRRs por componentes bacterianos aumenta el flujo glucolítico y un aumento de los niveles de intermediarios glucolíticos (Everts et al., 2014; Jha et al., 2015). Por ejemplo, en los macrófagos estimulados con diferentes especies bacterianas como Salmonella Typhimurium, Mycobacterium tuberculosis o E.coli se ha observado un aumento de la glucólisis y la producción de lactato (Garaude et al., 2016; Tannahill et al., 2013). En los macrófagos estimulados con LPS, se ha descrito que la vía de las pentosas fosfato también está aumentada, además de la glucólisis (Jha et al., 2015), aunque se desconocen los mecanismos involucrados. El fumarato, metabolito del ciclo TCA y producto enzimático del CII, tiene efectos antibacterianos al impedir el crecimiento de E.coli y S. Typhimurium, mientras que el succinato, otro metabolito del ciclo TCA, no mostraba sin embargo efectos significativos (Garaude et al., 2016) (Figura 5).

Hay nuevos estudios sobre el metabolismo de los ácidos grasos durante la activación de los fagocitos. Se conoce que el reconocimiento de bacterias por los TLRs aumenta la captación de ácidos grasos y su incorporación a los triglicéridos para su 
almacenamiento, reduciendo la oxidación de ácidos grasos y la lipólisis (Huang et al., 2014). Por otra parte, la sintasa de ácidos grasos en macrófagos está inducida a través de un mecanismo que requiere de la proteína mitocondrial Ucp2 (Uncoupling protein 2) (Moon et al., 2015).

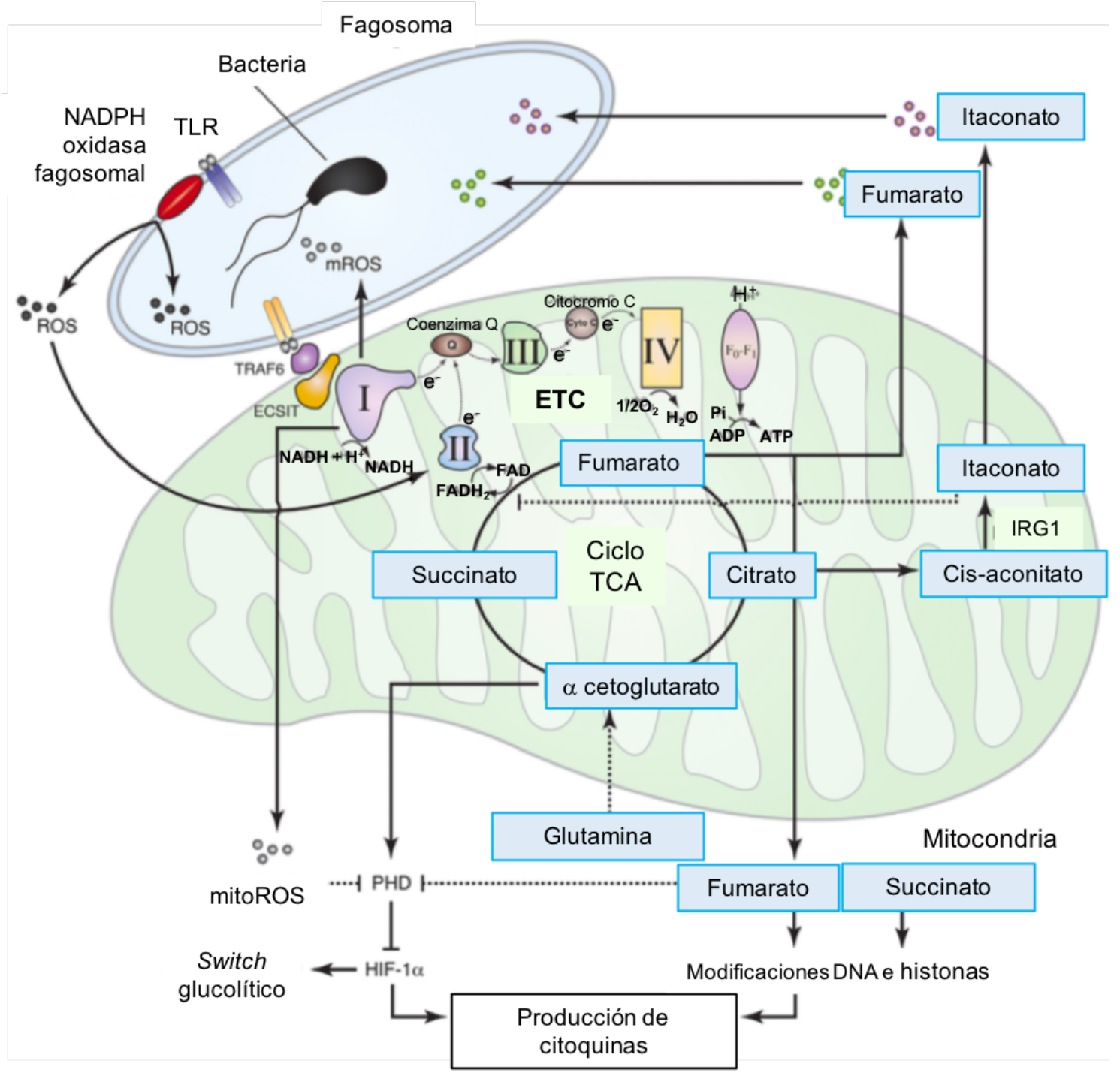

Figura 5. Metabolismo mitocondrial en el macrófago. Imagen adaptada de Sancho et al., 2017.

Los complejos mitocondriales son importantes en los macrófagos al contribuir directamente en el proceso de fagocitosis y en sus funciones bactericidas generando ROS. Los ROS del fagosoma son un componente principal para destruir las bacterias dentro de los macrófagos junto con los mitoROS. En los macrófagos expuestos a bacterias hay una interacción entre los TLRs (TLR1, TLR2 y TLR4) y el Cl mitocondrial 
resultando en la producción de mitoROS. Esta señalización está mediada por la asociación de TRAF6 (TNF Receptor-Associated Factor 6) con ECSIT (Evolutionarily conserved signaling intermediate in Toll pathway), proteína adaptadora de señalización en la vía Toll requerida para el ensamblaje del complejo I mitocondrial. Los macrófagos que carecen de ECSIT o TRAF6 tienen niveles reducidos de mitoROS y por tanto una capacidad alterada para eliminar las bacterias (West et al., 2011b). Los macrófagos deficientes en Ucp2 e infectados con Toxoplasma gondii son más resistentes a la infección al generar más mitoROS en respuesta al parásito (Arsenijevic et al., 2000). Asimismo, estos macrófagos son más resistentes a Listeria monocytogenes (Rousset et al., 2006). Estos datos indican que la abundancia de Ucp2 en la célula regula la generación de mitoROS (Emre et al., 2007). Además, se ha demostrado que la pérdida de la proteína Ucp2 aumenta el potencial de membrana mitocondrial, lo que afecta de forma negativa a la capacidad fagocítica (Park et al., 2011). Los macrófagos deficientes en el factor transcripcional ERR $\alpha$ (Estrogen-Related Receptor $\alpha$ ), clave en la $\beta$-oxidación de ácidos grasos, o en el regulador transcripcional PGC1 $\beta$ (Peroxisome ProliferatorActivated Receptor Gamma (PPARy) Coactivator-1 $\beta$ ), producen menos mitoROS frente a Listeria monocytogenes mostrando una capacidad reducida en la eliminación de bacterias (Sonoda et al., 2007).

3. Familia de proteínas mitocondriales FASTK y su papel en el sistema inmunitario innato

En el laboratorio en el que se ha desarrollado mi trabajo de investigación se identificó y caracterizó una familia de proteínas mitocondriales llamada FASTK (FasActivated Serine/Threonine Kinase). Esta familia está compuesta por seis miembros: FASTK, el miembro fundador, y sus homólogos FASTKD1-FASTKD5 (Simarro et al., 2010a). Los estudios posteriores que se han realizado junto con los de otros grupos de investigación han estudiado el papel de estas proteínas en la regulación posttranscripcional de la mitocondria. La familia FASTK representa una de las familias más grandes de reguladores de la expresión génica mitocondrial descritas hasta ahora.

\subsection{Reguladores de la expresión génica mitocondrial y de su función}

En humanos el DNA mitocondrial (mtDNA) codifica 37 genes que se requieren para OXPHOS (Pearce et al., 2017). El mtDNA codifica 2 rRNA (subunidades $12 \mathrm{~s}$ y 16S), 22 RNA de transferencia (tRNA) necesarios para la síntesis de proteínas mitocondriales, y 13 genes codifican polipéptidos que forman parte de los complejos respiratorios mitocondriales I-IV (Fernández-Silva et al., 2003). Estos péptidos 
corresponden a 7 subunidades del complejo I (ND1, ND2, ND3, ND4, ND4L, ND5, ND6), una subunidad del complejo III (Citocromo b), tres subunidades del complejo IV (COX1, COX2, COX3), y dos subunidades del complejo V (ATP6 y ATP8) (Tuppen et al., 2010; Weigl et al., 2013; Schon et al., 2012). El resto de los polipéptidos componentes de estos complejos, así como el complejo II completo, están codificados por el DNA nuclear. El DNA mitocondrial está formado por dos cadenas distintas, la cadena pesada $(H)$ y la cadena ligera (L) (Temperley et al., 2010). Al contrario que el genoma nuclear, el mtDNA apenas tiene regiones no codificantes, los genes se encuentran situados uno a continuación del otro (Schapira, 2006). La única zona del mtDNA que no codifica ningún gen es la región del bucle de desplazamiento (D-loop), donde se localizan el origen de replicación de la cadena pesada $(\mathrm{OH})$, además de los promotores de la transcripción (LSP y HSP) y los elementos reguladores de la expresión génica (Figura 6).

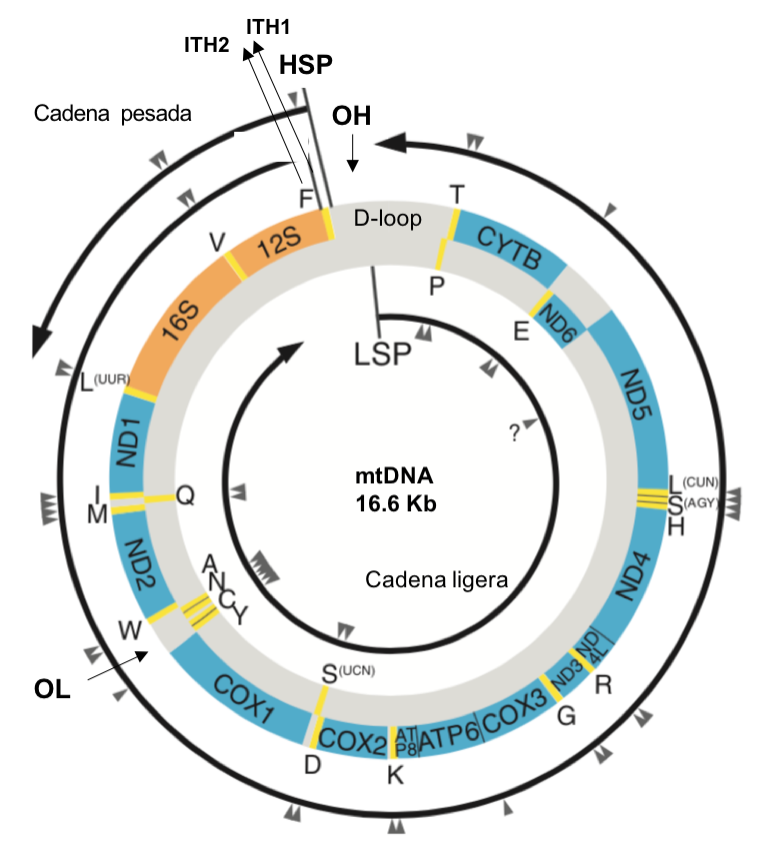

Figura 6. Genoma mitocondrial. Representación esquemática del genoma mtDNA de 16.6 kilobases $(k b)$ circular, de doble cadena. Se representan la cadena pesada $(H)$ y el círculo interior es la cadena ligera (L), con los promotores de transcripción (ITH1, ITH2 y LSP) que indican la dirección de la transcripción. El mtDNA codifica genes que codifican 2 mt-rRNAs (naranja), 22 mt-tRNAs (amarillo) y 13 polipéptidos esenciales (azul) que forman parte de los complejos respiratorios mitocondriales I-IV. Imagen adaptada de Chujo et al., 2012.

En la replicación del mtDNA se necesitan dos orígenes (OH y $\mathrm{OL}$ ) para cada cadena. La síntesis del DNA se inicia en la cadena pesada $(\mathrm{OH})$ y la replicación continúa hasta alcanzar la cadena ligera $(\mathrm{OL})$, momento en el cual comienza la síntesis de la segunda cadena del DNA (Bonawitz et al., 2006). La transcripción del mtDNA se inicia a partir de 3 promotores localizados en el D-loop, uno para la cadena ligera $(L)$ y dos para la cadena pesada $(\mathrm{H} 1$ y $\mathrm{H} 2)$. Debido a la naturaleza policistrónica de la 
transcripción mitocondrial, los mecanismos de regulación post-transcripcionales son especialmente importantes en la mitocondria. Cada hebra de mtDNA da lugar a moléculas policistrónicas que se procesan para producir RNAs individuales. Esto se logra, en la mayoría de los casos, con el modelo del procesamiento del mtRNA conocido como "puntuación por los tRNAs", que implica el plegamiento de los tRNAs y su procesamiento a través de la escisión endonucleolítica de la RNasa P y RNasa Z, y dando lugar a los mRNAs y rRNAs independientes a partir del precursor policistrónico (Rossmanith, 2011; Brzezniak et al., 2011). Los rRNAs y la mayoría de los mRNAs están flanqueados por tRNAs que actúan como señales de procesamiento. Tanto la naturaleza policistrónica del tránscrito como la presencia de tRNAs flanqueantes definen este modelo de "puntuación por los tRNAs". Sin embargo, este modelo no explica el procesamiento de los mRNAs no canónicos, aquellos que no están flanqueados por tRNAs, como COX3, COX1, CYTB, ND6, ND5, ATP8/6. Así pues, se han identificado importantes proteínas en la regulación post-transcripcional de unión al RNA (RBPs, $R N A$-binding proteins) en la mitocondria para el procesamiento de los mRNAs no canónicos. Entre estas proteínas destacan las de la familia de proteínas FASTK, y otras como: GRSF1 (G-Rich RNA Sequence Binding Factor 1), necesaria para la expresión de mtRNA y la síntesis de proteínas en la mitocondria; LRPPRC (Leucine-Rich Pentatricopeptide Repeat-Containing protein), promueve la transcripción y la estabilidad de los mt-mRNAs; SLIRP (SRA stem-Loop-Interacting RNA-binding Protein) necesaria para el mantenimiento de los mtRNAs que codifican para proteínas; PTCD1 (Pentatricopeptide repeat Domain 1), importante en el procesamiento de tRNAs; PTCD2 (Pentatricopeptide repeat Domain 2), involucrado en la expresión del citocromo b y el ensamblaje del complejo III; PTCD3 (Pentatricopeptide repeat Domain 3), se une al rRNA mitocondrial 12S, necesario para la síntesis correcta de proteínas mitocondriales; y MRPS27 (Mitochondrial Ribosomal Protein S27), importante para la traducción al asociarse con rRNA 12S (Mootha et al., 2003; Baughman et al., 2009). LRPPRC y SLRIP forman un complejo encargado de la maduración y estabilización de los mRNAs facilitando la poliadenilación de mRNA, que está mediada por MTPAP (Mitochondrial Poly(A) Polymerase) y la PNPasa (Polynucleotide Phosphorylase; es una exonucleasa con actividad 3'-5') (Chujo et al., 2012; Nagaike et al., 2005). Por todo esto, las RBPs tienen un papel importante en el metabolismo mitocondrial y como consecuencia en la síntesis de proteínas mitocondriales, ya que regulan el splicing, la poliadenilación, el transporte y la localización del RNA, la estabilización del RNA y la traducción. Recientemente se ha descrito que los gránulos de RNA mitocondrial (MRGs, Mitochondrial RNA Granules) concentran los factores clave de procesamiento de la transcripción y maduración del RNA, incluyendo las subunidades RNasa P, RNasa Z y 
GRSF1, así como parte del complejo hSuv3p-PNPasa o degradosoma (Antonicka et al., 2013; Jourdain et al., 2013; Jourdain et al., 2016).

La identificación de los miembros de la familia FASTK ha permitido conocer más sobre los mecanismos moleculares que controlan el procesamiento post-transcripcional y la traducción del RNA mitocondrial. Una de las características de las proteínas FASTK es que tienen varias funciones, a veces opuestas, en la biología del RNA mitocondrial, como explicaremos en este capítulo en un apartado posterior (Tabla 5).

\subsection{Características estructurales de las proteínas FASTK}

Todos los miembros de esta familia, FASTKDs, se caracterizan por tener una señal de localización mitocondrial (MTS, Mitochondria-Targeting Sequence) en el extremo amino terminal (N-terminal) (Simarro et al., 2010a), y la presencia de tres dominios conservados (FAST_1, FAST_2 y RAP) situados en el extremo carboxilo. FAST_1 (aproximadamente de 70 aminoácidos) y FAST_2 (aproximadamente de 90 aminoácidos) son ricos en leucinas y de función desconocida. RAP (acrónimo de RNAbinding domain abundant in Apicomplexans) es un dominio de unión al RNA (Figura 7A), y está compuesto de aproximadamente 60 aminoácidos (Lee et al., 2004; Simarro et al., 2010a).

Los modelos estructurales de las proteínas FASTK indican que los dominios FAST_1, FAST_2 y RAP comparten una arquitectura global similar a las proteínas PPR (Pentatricopeptide Repeat), incluyendo repeticiones de los motivos $\alpha$-hélice. Estructuralmente, los dominios PPR contienen una serie de repeticiones PPR, y cada repetición PPR forma un par de $\alpha$-hélices antiparalelas de repetición de aproximadamente 35 aminoácidos. Estas repeticiones de $\alpha$-hélices antiparalelas en la proteína producen una superhélice con una ranura central capaz de reconocer una secuencia específica de cadena de RNA (Hall, 2016). Hay estudios anteriores que sugieren que los dominios de las proteínas FASTK pueden estar relacionados con dominios de repeticiones octatricopéptidos de plantas (OPR, Octatricopeptide Repeat), y se asemejan a los dominios PPR en plantas en estructura y función (Jourdain et al., 2015; Hall et al., 2016; Kleinknecht et al., 2014), y en relación a las 44 proteínas OPR que presenta Chlamydomonas reinhardtii, 16 de éstas contienen un dominio FAST (Eberhard et al., 2011).

La familia de proteínas FASTK es específica del reino Metazoa. Su análisis filogenético sugiere que apareció temprano en la evolución de los organismos multicelulares. El ancestral placozoo Trichoplax adhaerens, expresa tres homólogos FASTK, mientras que las proteínas FASTK están ausentes en levaduras y plantas (Figura 7B) (Finn et al., 2017). Durante la evolución, los genes han sufrido duplicaciones 
y mutaciones, y la mayoría de los genomas de vertebrados codifican para los seis miembros de la familia, a excepción de Drosophila melanogaster que solo codifica dos de ellos. Se predice que, en esta especie, ambas proteínas de la familia FASTK (CG31643 y CG13850) están localizadas en las mitocondrias, lo que sugiere que son homólogos verdaderos de las proteínas humanas FASTK (Jourdain et al., 2017) (Figura 7B). Las proteínas FASTK tienen baja homología de secuencia entre sí, siendo esta homología mayor entre los dominios FAST_1, FAST_2 y RAP que la observada en el extremo amino terminal (N-terminal) (Simarro et al., 2010a). Además, los tres dominios se pueden encontrar por separado. RAP es el dominio más ancestral y más ampliamente distribuido entre especies, presente en algunas eubacterias, arqueas, virus y plantas. La estructura particular del dominio C-terminal en las proteínas FASTK se conserva a lo largo de la evolución. El dominio FAST_1 existe en plantas y animales, pero no está presente en procariotas, mientras que el dominio FAST_2 es exclusivo de animales (Jourdain et al., 2017).

A

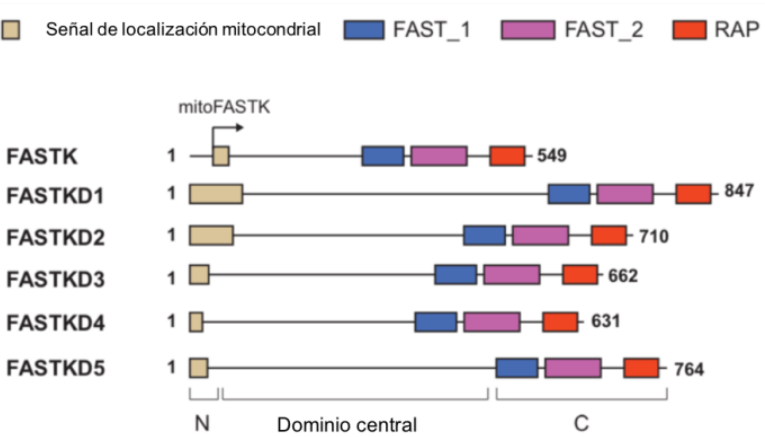

B

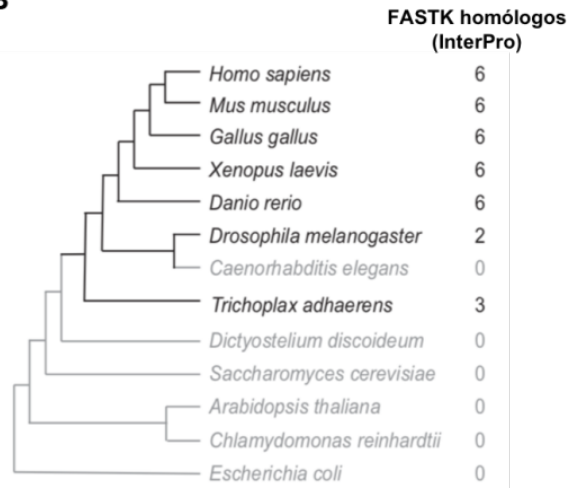

Figura 7. A. Representación esquemática de las proteínas de la familia FASTK. B. Conservación de la familia de proteínas FASTK en la evolución según InterPro. Imagen tomada de Jourdain et al., 2017.

\subsection{Localización de las proteínas FASTK}

FASTK es el miembro fundador de la familia de proteínas mitocondriales descrita. Está compuesto por 515 aminoácidos. FASTK puede localizarse en diferentes compartimentos celulares: citoplasma, núcleo y mitocondria. Inicialmente, FASTK se propuso que actuaba como una proteína quinasa, pero el dominio con acción quinasa no se conserva dentro de la familia y esta actividad no se acepta en la actualidad (Simarro et al., 2007).

Todos los miembros de la familia FASTK (FASTKD1-FASTKD5) se localizan en la mitocondria (Figura 8), y se expresan de forma ubicua, aunque son más abundantes en tejidos enriquecidos en mitocondrias como el músculo esquelético, el corazón y el tejido adiposo marrón (también conocido como grasa parda). El $50 \%$ de la proteína 
FASTK endógena reside en la mitocondria (mitoFASTK), mientras que el resto se distribuye entre el núcleo y el citosol (cytoFASTK). La isoforma mitocondrial de FASTK se sintetiza a través de un sitio alternativo de iniciación de la traducción y carece de los primeros 34 aminoácidos presentes en el extremo N-terminal de la proteína FASTK, mostrando un MTS (Jourdain et al., 2015; Simarro et al., 2010a). Algunos de los miembros de la familia FASTK, incluyendo a FASTK, FASTKD1, FASTKD2 y FASTKD5 se localizan y se relacionan con los gránulos de RNA mitocondriales (MRGs) (Jourdain et al., 2017).

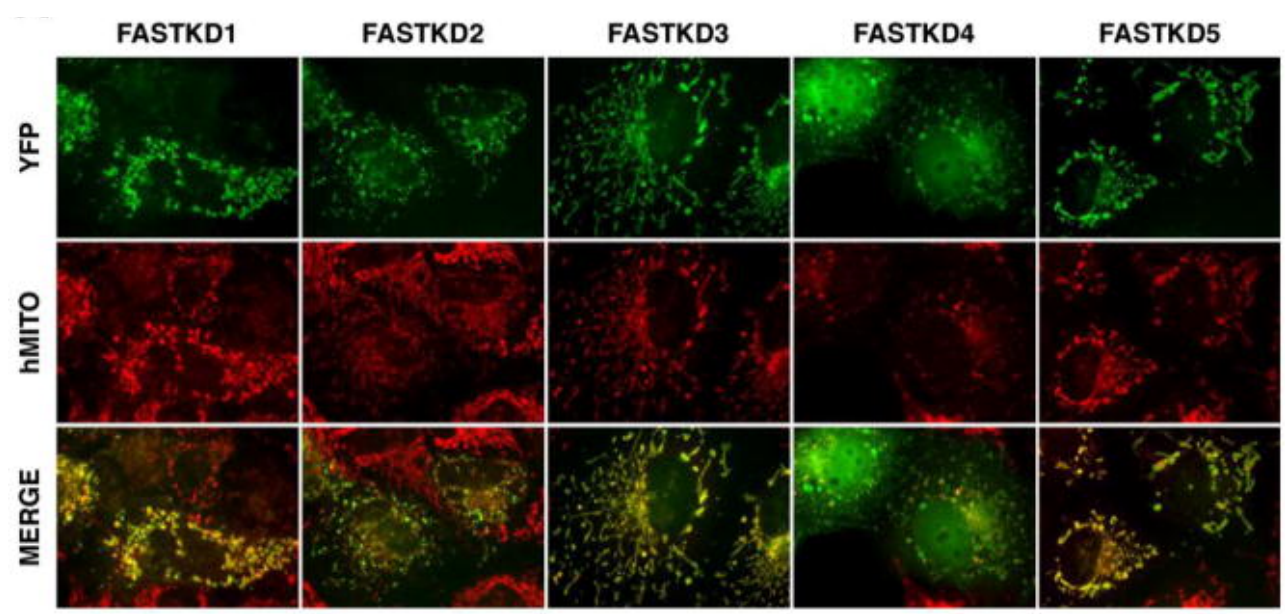

Figura 8. Localización celular de los miembros de la familia FASTKD1-5. Todos ellos se localizan en la mitocondria. Las células fueron teñidas con anticuerpos antimitocondriales de suero humano y analizados por inmunofluorescencia. Imagen adaptada de Simarro et al., 2010a.

Los genes que codifican a los miembros de la familia FASTK en humanos, se localizan en diferentes cromosomas como se indica en la tabla 4.

Tabla 4. Localización cromosómica de todos los miembros de la familia FASTK en la especie humana.

\begin{tabular}{|c|c|}
\hline $\begin{array}{c}\text { Miembros de la } \\
\text { familia FASTK }\end{array}$ & $\begin{array}{c}\text { Localización } \\
\text { cromosómica }\end{array}$ \\
\hline FASTK & $7 \mathrm{q} 35$ \\
\hline FASTKD1 & $2 \mathrm{q} 31$ \\
\hline FASTKD2 & $2 \mathrm{q} 33.3$ \\
\hline FASTKD3 & $5 \mathrm{p} 15.31$ \\
\hline FASTKD4 & $7 \mathrm{p} 15.31$ \\
\hline FASTKD5 & $20 \mathrm{p} 13$ \\
\hline
\end{tabular}




\subsubsection{Papel de FASTK en el citoplasma}

En el citoplasma (cytoFASTK) se localiza en los gránulos de estrés, que son agregados citoplasmáticos de mRNAs que no se traducen (stalled), asociados a factores de iniciación de la traducción, a la subunidad ribosomal $40 S$ y a varias proteínas de unión a RNA. También se localiza en estructuras asociadas a otros gránulos de estrés denominados cuerpos de procesamiento o $P$ bodies, que son gránulos de RNA citosólicos y cuyos componentes participan en la degradación de ciertos mRNAs. Estos dos tipos de gránulos tienen un papel en el almacenamiento y el recambio (turnover) de ciertos mRNAs en el citoplasma (Kedersha et al., 2005; Simarro et al., 2007).

\subsubsection{Papel de FASTK en el núcleo}

En el núcleo FASTK regula el corte y empalme (splicing) alternativo de exones flanqueados por secuencias de reconocimiento de corte y empalme (splicing). El splicing alternativo es un proceso de regulación de la expresión génica permitiendo obtener a partir de un tránscrito primario de mRNA o pre-mRNA distintas moléculas de mRNA maduras y proteínas (Bonomi et al., 2013). Se han utilizado plásmidos portadores de minigenes para el estudio de splicing: el receptor del factor de crecimiento de fibroblasto 2 (FGFR2, Fibroblast Growth Factor Receptor-2) para el estudio de la inclusión del exón IIlb, y del receptor Fas para el estudio de la inclusión del exón 6. FASTK modula la inclusión del exón 6 del receptor Fas a través de efectos sinérgicos con TIA-1 ( $T$-cell Intracelular Antigen 1) /TIAR (TIA-1-Related) así como los factores de splicing adicionales. El tránscrito de Fas que incluye el exón 6 da lugar a un receptor transmembrana que promueve la apoptosis, mientras que el tránscrito que no presenta el exón 6 da lugar a un receptor soluble que inhibe la apoptosis (Izquierdo et al., 2007). También se ha descrito que FASTK es un regulador del splicing que se recluta por IAS1 (Intronic Activator Sequence 1, potenciador intrónico de splicing que posee regiones ricas en uridina), para promover la inclusión del exón Illb de FGFR2. Sin embargo, a diferencia de TIA1, FASTK no se une a la secuencia IAS1, pero permite a U1-snRNP (U1-Small Nuclear Ribonucleoprotein) unirse en el sitio de empalme 5' ya que interactúa con otros factores de unión a IAS1. Se ha demostrado que los últimos 188 aminoácidos de FASTK, son indispensables para la inclusión del exón IIlb en el tránscrito de FGFR2. También se ha descrito que FASTK se une a otros reguladores de splicing como HNRPK (Heterogeneous Nuclear Ribonucleoprotein K), KHDRBS1 (KH Domain-containing, RNA-Binding, Signal transduction-associated protein 1, también conocido como Sam68), TIAL1 (también conocido como TIAR) y SF3B4 (Splicing Factor 3b subunit 4, 
también conocido como SAP49), necesarios para la activación del exón Illb (Simarro et al., 2007).

Hay poca literatura sobre cómo el splicing alternativo del mRNA afecta a la función de las proteínas que participan en la fagocitosis (Yamaguchi et al., 2010; Malik et al., 2013). Hasta ahora no se han identificado alteraciones tras estudiar el perfil de expresión de exones en macrófagos peritoneales de ratones FASTK KO en el proceso de fagocitosis (Simarro et al., 2007).

\subsubsection{Papel de FASTK en la mitocondria}

La isoforma mitocondrial de FASTK (mitoFASTK), como se ha mencionado anteriormente, se localiza en gránulos de RNA mitocondriales (MRGs), se sintetiza desde un sitio de iniciación de traducción alternativo y se inicia en la metionina 35. Esta isoforma, mitoFASTK, interactúa con mRNA del ND6 (MT-ND6), es el único mRNA codificado por la cadena ligera, que codifica una subunidad esencial para la actividad del Cl. A través de esta interacción, FASTK protege al mRNA del ND6 de la degradación por el degradosoma, a través de la unión de FASTK al precursor del RNA de la hebra ligera en varios lugares de la región codificante del ND6, manteniendo la forma madura del mRNA de ND6 (Jourdain et al., 2015).

Se ha demostrado que la deficiencia de FASTK tanto en la línea celular 143B como en diferentes tejidos de ratón en músculo esquelético y cardíaco, produce una reducción del 50 \% en la actividad del complejo I (figura 9). Se confirmó que había una disminución del MT-ND6 en cerebro, corazón, músculo e hígado en los ratones deficientes de FASTK, demostrando que mitoFASTK es esencial para la biogénesis normal del MT-ND6 (Jourdain et al., 2015). 
A

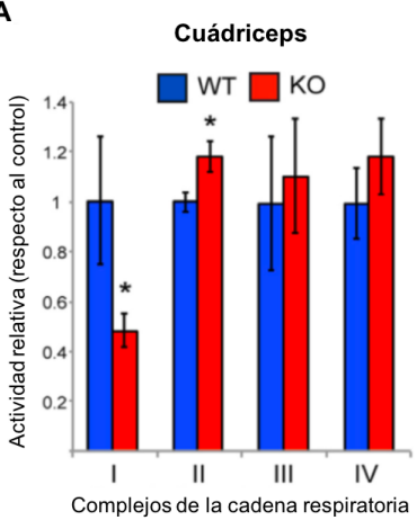

B

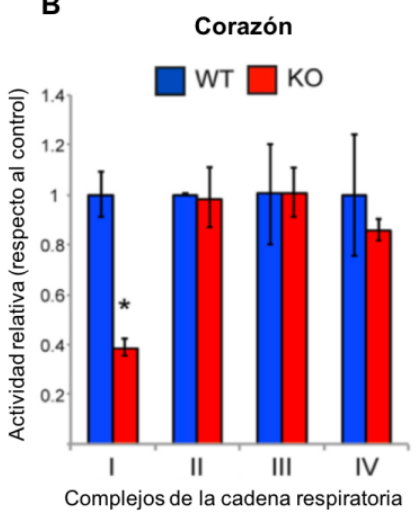

Figura 9. Análisis de la actividad enzimática mitocondrial relativa de los diferentes complejos que forman la cadena respiratoria en diferentes tejidos en ratones FASTK silvestres (WT) y knockout (KO): $\boldsymbol{A}$. En cuádriceps y B. En corazón. Imagen tomada y modificada de Jourdain et al., 2015.

3.4. Miembros de la familia de proteínas FASTK: características, funciones y relación con patologías humanas

Todos los miembros de la familia FASTK (FASTK y los homólogos FASTKD1FASTKD5) son proteínas de unión al RNA, y están relacionados estructuralmente pero cada uno de ellos tiene una función distinta en la regulación de la biología del RNA mitocondrial (se detalla en tabla 5). La familia de proteínas FASTK están implicadas en casi todos los procesos del metabolismo del RNA en la mitocondria. Estas funciones incluyen el procesamiento de tRNA, uniones a los tránscritos tRNA, la estabilidad del RNA, la pseudouridilación del rRNA 16S, el ensamblaje del ribosoma y la traducción mitocondrial (Figura 10), que se detallan a continuación: 
Estabilidad RNA y generación 3'

(ej.: FASTK)

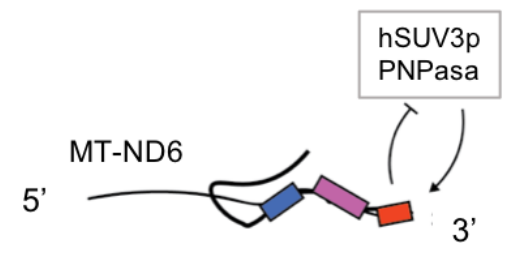

$3^{\prime}$
Procesamiento pre-RNA

(ej.: FASTKD4)

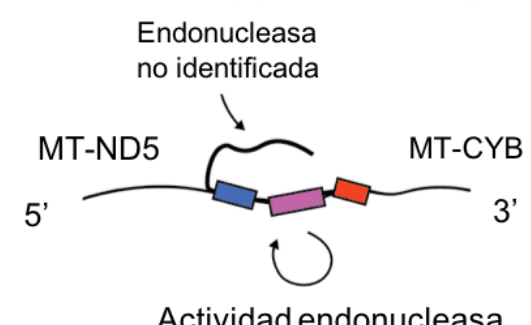

Regulación traducción

(ej.: FASTKD3)
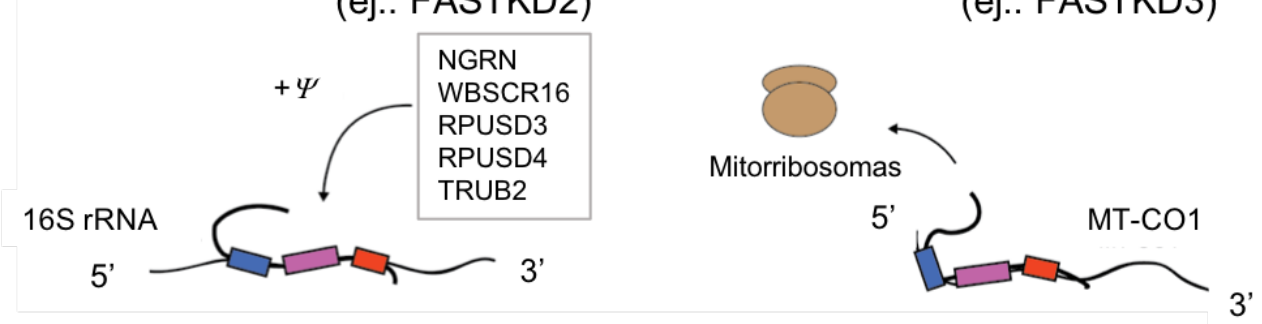

Figura 10. Mecanismo de acción propuesto de la familia de proteínas FASTK. ч:pseudouridina. Imagen adaptada de Jourdain et al., 2017.

FASTK interactúa con uno de los precursores de la transcripción que no está flanqueado por tRNAs, como el mRNA no canónico del ND6, codificado por la cadena ligera, puesto que hay ausencia de tRNA en el extremo 3' de su secuencia codificante. A través de esta interacción, FASTK protege al mRNA del ND6 de la degradación por hSuv3p-PNPasa, manteniendo la forma madura del mRNA del ND6 (Jourdain et al., 2015). Otros miembros de la familia FASTK, están involucrados en la estabilidad del RNA (como FASTKD1, FASTKD3 y FASTKD4) (Figura 10). Por ejemplo, FASTKD1 colocaliza con mtDNA e interacciona con RNAs mitocondriales (Boehm et al., 2017). Estas proteínas pueden estar involucradas también en la metilación, poliadenilación o pseudouridilación como es el caso de FASTKD2, que interacciona con sintasas pseudouridina mitocondriales. Se ha identificado que FASTKD2 interacciona con GRSF1, y las proteínas de unión al RNA: NGRN (Neugrin, neurit outgrowth associated) y WB-SCR16 (Williams-Beuren Syndrome Chromosal Region); así como tres pseudouridinas sintasas mitocondriales: RPUSD3 (RNA pseudouridine synthase D3), RPUSD4 (RNA pseudouridine synthase D4), y TRUB2 (TruB pseudouridine synthase family member 2); por lo que desempeña un papel en la pseudouridilación y estabilidad del rRNA 16S, el ensamblaje del ribosoma y la traducción mitocondrial (Jourdain et al., 2015; Antonicka et al., 2015; Popow et al., 2015). FASTKD3 identifica proteínas involucradas en el procesamiento de RNA y traducción mitocondrial. Por ejemplo, se requiere para la síntesis eficiente de la proteína COX1 (Boehm et al., 2016) (Tabla 5). 
Se plantea que ciertos miembros de la familia no solo actúan como adaptadores a secuencias de RNA codificadas por el genoma mitocondrial, sino que también tienen un dominio catalítico con actividad endonucleasa, como por ejemplo FASTKD4. También están implicados en el procesamiento de RNA (FASTKD4, FASTKD5) que pueden reclutar una endonucleasa no identificada para realizar el procesamiento de las uniones de RNA sin tRNA como MT-CYB+MT-ND5 o MT-ATP8/6+MT-CO3 (Antonicka et al., 2017; Antonicka y Shoubridge, 2015; Boehm et al., 2017; Boehm et al., 2016; Han et al., 2017; Popow et al., 2015; Wolf y Mootha, 2014; Jourdain et al., 2015). Aunque todavía no se conocen de forma precisa los mecanismos por los cuales las proteínas FASTK ejercen sus funciones.

Por otra parte, se conoce aún poco sobre el papel de FASTK en la patogénesis de enfermedades humanas. En cáncer de páncreas y cáncer epitelial de ovario hay sobreexpresión de FASTK (Bauer et al., 2009; Yoon et al., 2010). Se ha descrito en la línea celular de cáncer de ovario SKOV-3 la sobreexpresión de FASTK, como uno de los genes responsables de la apoptosis tras el tratamiento con el fármaco cisplatino (Yoon et al., 2010). Curiosamente la ausencia de FASTK en las neuronas primarias y en la línea celular de neuroblastoma humano SH-SY5Y, aumenta la formación de las neuritas (Loh et al., 2008). Se ha estudiado que FASTK se sobreexpresa en los tumores pancreáticos, afectando a la expresión de los tránscritos que codifican las proteínas implicadas en la proliferación celular, la adhesión y la motilidad. También se sobreexpresa en la micosis fungoide (van Doorn et al., 2009). Además, se ha identificado el gen FASTK como posible protector en la retinopatía diabética (Shtir et al., 2016). 
Tabla 5. Miembros de la familia FASTK (FASTKD1-5): características, funciones y relación con patologías humanas.

\begin{tabular}{|c|c|c|c|c|c|c|}
\hline $\begin{array}{l}\text { Miembro } \\
\text { FASTKD }\end{array}$ & $\begin{array}{l}N^{\circ} \text { de } \\
\text { amino } \\
\text { ácidos }\end{array}$ & $\begin{array}{l}\text { Expresión mRNA en } \\
\text { tejidos humanos }\end{array}$ & $\begin{array}{l}\text { Localización } \\
\text { celular }\end{array}$ & Funciones & $\begin{array}{l}\text { Relación con patogénesis de } \\
\text { enfermedades }\end{array}$ & Referencias \\
\hline FASTKD1 & $\begin{array}{l}847 \\
\text { aa }\end{array}$ & $\begin{array}{l}\text { Corazón, } \\
\text { cerebro, } \\
\text { testículos, } \\
\text { tiroides }\end{array}$ & MRGs & $\begin{array}{l}\text { - Estabilidad del mRNA } \\
\text { mitocondrial } \\
\text { - Depleción de FASTKD1 produce } \\
\text { acumulación de mRNA MT-ND3 } \\
\text { y aumento de la actividad del Cl }\end{array}$ & $\begin{array}{l}\text { - Sobreexpresión en pacientes } \\
\text { con cáncer de endometrio y } \\
\text { en leucemia linfoblástica con } \\
\text { peor pronóstico }\end{array}$ & $\begin{array}{l}\text { Simarro et al., 2010a } \\
\text { Boehm et al., } 2017 \\
\text { Han et al., } 2017 \\
\text { Colas et al., } 2011 \\
\text { Wang et al., } 2015\end{array}$ \\
\hline FASTKD2 & $\begin{array}{l}710 \\
\text { aa }\end{array}$ & $\begin{array}{l}\text { Tiroides, grasa } \\
\text { parda, corazón, } \\
\text { ovario }\end{array}$ & MRGs & $\begin{array}{l}\text { - Ensamblaje del ribosoma } \\
\text { mitocondrial (síntesis de rRNA } \\
16 \mathrm{~S} \text { mitocondrial) y traducción } \\
\text { mitocondrial } \\
\text { - Biogénesis y actividad de los } \\
\text { complejos OXPHOS en células } \\
\text { osteosarcoma } 143 \mathrm{~B} \text { y células } \\
\text { endoteliales HEK293. Su } \\
\text { deficiencia resulta en un defecto } \\
\text { en el ensamblaje de los } \mathrm{CI} \text {, CIII, } \\
\mathrm{CIV}, \mathrm{CV}\end{array}$ & $\begin{array}{l}\text { - Mutaciones homocigotas en el } \\
\text { gen en dos hermanos con } \\
\text { encefalomiopatía mitocondrial } \\
\text { asociado a deficiencia del CIV } \\
\text { - Mutaciones heterocigotas de } \\
\text { FASTKD2 en paciente con } \\
\text { síndrome de MELAS } \\
\text { - Puede inducir la apoptosis de } \\
\text { líneas celulares de mama y } \\
\text { próstata } \\
\text { - Disminuye la expresión de } \\
\text { FASTKD2 en astrocitos de } \\
\text { pacientes con Alzheimer } \\
\text { - Modulación de la } \\
\text { neurodegeneración para } \\
\text { pérdida de memoria en el } \\
\text { envejecimiento cognitivo } \\
\text { normal y demencia } \\
\text { - Ataxias hereditarias } \\
\text { - Sobreexpresados en células } \\
\text { madre derivadas de cordón } \\
\text { umbilical humano }\end{array}$ & $\begin{array}{l}\text { Simarro et al., 2010a } \\
\text { Jourdain et al., 2015 } \\
\text { Antonicka et al., } 2015 \\
\text { Popow et al., } 2015 \\
\text { Antonicka et al., } 2017 \\
\text { Guezzi et al., } 2008 \\
\text { Yoo et al., } 2017 \\
\text { Yeung et al., } 2011 \\
\text { Sekar et al., } 2015 \\
\text { Das et al., 2014 } \\
\text { Ramanan et al., } \\
\text { 2015a y 2015b } \\
\text { Pyle et al., 2015 } \\
\text { Garzón et al., } 2012\end{array}$ \\
\hline FASTKD3 & $\begin{array}{l}662 \\
\text { aa }\end{array}$ & $\begin{array}{l}\text { Hígado, tiroides, } \\
\text { cerebro, bazo, } \\
\text { testículos y } \\
\text { ovario }\end{array}$ & Mitocondria & $\begin{array}{l}\text { - Estabilidad mRNA, traducción } \\
\text { MT-CO1 } \\
\text { - Procesamiento y traducción RNA } \\
\text { mitocondrial (control post- } \\
\text { transcripcional) } \\
\text { - Necesario para la respiración } \\
\text { celular } \\
\text { - Síntesis eficiente de la proteína } \\
\text { COX1, por consiguiente para la } \\
\text { actividad y ensamblaje CIV } \\
\text { - Modula la vida media de varios } \\
\text { tránscritos mitocondriales (MT- } \\
\text { ND2, MT-ND3, MT-CYB, MT- } \\
\text { CO2, MT-ATP8/6) }\end{array}$ & $\begin{array}{l}\text { - No se conocen estudios sobre } \\
\text { FASTKD3 en patogénesis de } \\
\text { enfermedades humanas }\end{array}$ & $\begin{array}{l}\text { Simarro et al., 2010a } \\
\text { Boehm et al., } 2016\end{array}$ \\
\hline FASTKD4 & $\begin{array}{l}631 \\
\text { aa }\end{array}$ & $\begin{array}{l}\text { Grasa parda, } \\
\text { corazón, } \\
\text { testículos, } \\
\text { cerebro, higado }\end{array}$ & $\begin{array}{l}\text { Matriz } \\
\text { mitocondrial }\end{array}$ & $\begin{array}{l}\text { - Estabilidad y procesamiento del } \\
\text { mRNA mitocondrial } \\
\text { - Unión a la mayoría de tránscritos } \\
\text { codificados por la cadena } \\
\text { pesada } \\
\text { - Regulación de la estabilidad de } \\
\text { los tránscritos MT-CO1, MT-ND3 } \\
\text { y MT-CO2 } \\
\text { - Su silenciamiento disminuye los } \\
\text { niveles de MT-ATP8/6, MT-CO1, } \\
\text { MT-CO2, MT-CO3, MT-ND3, MT- } \\
\text { CYB. MT-ND5 }\end{array}$ & $\begin{array}{l}\text { - Gen afectado en pacientes } \\
\text { con síndrome de Sezary } \\
\text { - Diagnóstico de glioblastoma } \\
\text { - Mieloma múltiple extramedular }\end{array}$ & $\begin{array}{l}\text { Wolf y Mootha, } 2014 \\
\text { Simarro et al., 2010a } \\
\text { Boehm et al., 2017 } \\
\text { Prasad et al., 2016 } \\
\text { Varghese et al., } 2016 \\
\text { Sevcikova et al., } 2015 \\
\text { Sarasquete et al., } \\
2013 \\
\text { Shtir et al., } 2016\end{array}$ \\
\hline FASTKD5 & $\begin{array}{l}764 \\
\text { aa }\end{array}$ & $\begin{array}{l}\text { Grasa parda, } \\
\text { corazón }\end{array}$ & MRGs & $\begin{array}{l}\text { - Procesamiento de los mRNA: } \\
\text { MT-CO1, MT-CO3. } \\
\text { - Proliferación celular } \\
\text { - Maduración de los mRNAs no } \\
\text { flanqueados por tRNA (COX1, } \\
\text { ATP8/6, COX3, ND5-CytB) } \\
\text { - Se une a rRNA 12S y a todos los } \\
\text { mRNA mitocondriales excepto } \\
\text { ND3 } \\
\text { - El silenciamiento de FASTKD5 } \\
\text { produce un defecto en la } \\
\text { traducción de COX1, y por tanto } \\
\text { en la actividad del CIV. También } \\
\text { un defecto en la traducción de } \\
\text { ND2, ND1, CytB, COX2 y COX3 }\end{array}$ & $\begin{array}{l}\text { - No se conocen estudios sobre } \\
\text { FASTKD5 en patogénesis de } \\
\text { enfermedades humanas }\end{array}$ & Antonicka et al., 2015 \\
\hline
\end{tabular}




\subsection{Papel de FASTK en el sistema inmunitario innato}

FASTK es un componente clave en la respuesta inmunitaria innata. Se conoce que FASTK se sobreexpresa en células mononucleares de sangre periférica de pacientes con enfermedades inflamatorias mediadas por el sistema inmunitario, incluyendo la artritis reumatoide, el lupus eritematoso, la diabetes tipo I, la esclerosis múltiple, el asma y la atopia (Brutsche et al., 2001; Maas et al., 2002). Se ha estudiado el papel de FASTK en el sistema inmunitario mediante la generación de ratones modificados genéticamente que carecen de FASTK (FASTK KO). En el primer estudio realizado se demuestra que FASTK regula el reclutamiento de los neutrófilos en dos modelos de inflamación pulmonar. En el modelo de inflamación pulmonar alérgica mediante la exposición a extractos de ácaros de polvo, se observó una reducción de la acumulación de los neutrófilos en el pulmón. En un modelo de daño pulmonar agudo mediante la exposición a lipopolisacárido, los ratones FASTK KO mostraron una reducción en la infiltración de los neutrófilos y en las concentraciones de citoquinas y quimioquinas (IL-6, IL-23, TNF- $\alpha$, MIP-2, KC) en el lavado broncoalveolar como se representa en la figura 11 (Simarro et al., 2010b). Por consiguiente, FASTK se requiere para una respuesta inmunitaria innata eficiente en los pulmones de ratón, y es necesario para el reclutamiento de los neutrófilos en los pulmones inflamados.

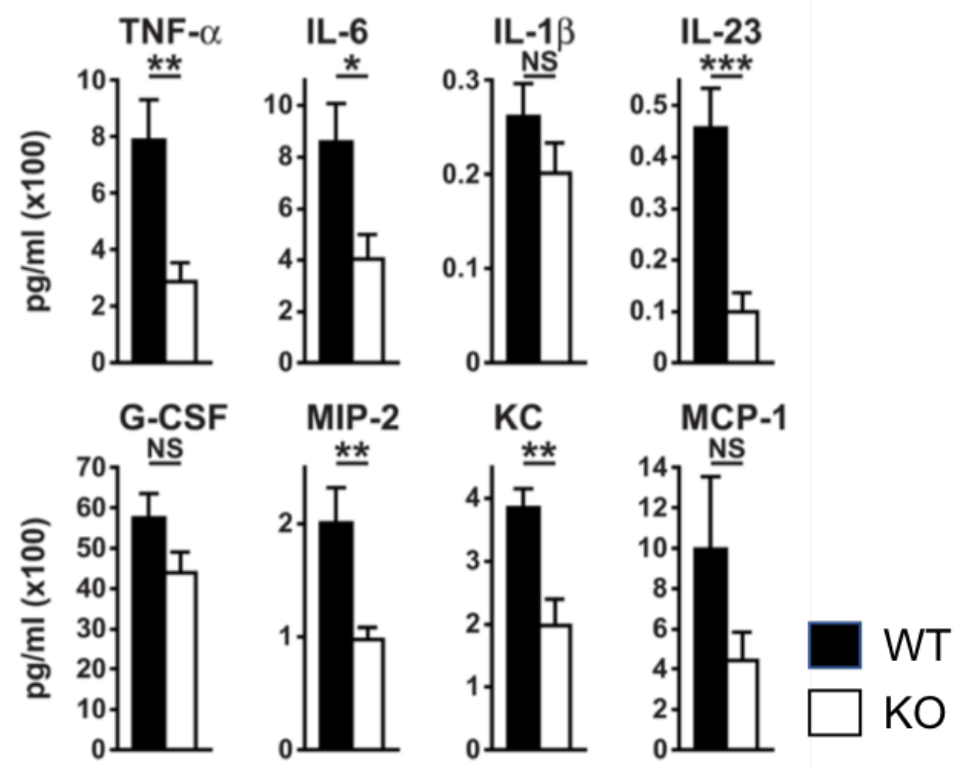

Figura 11. Representación de los niveles de citoquinas y quimioquinas (TNF $\alpha$, IL-6, IL-1 $\beta$, IL-23, G-CSF, MIP-2 y MCP-1) en el fluido del lavado broncoalveolar. Se representan en color negro los ratones de tipo salvaje (WT) y en blanco los ratones deficientes de FASTK (KO). Imagen tomada de Simarro et al., $2010 \mathrm{~b}$. 
Se ha identificado en un modelo de inflamación articular $\mathrm{K} / \mathrm{BxN}$, que los ratones FASTK KO desarrollaban una artritis menos severa en comparación con los ratones de tipo salvaje (WT). Luego FASTK es coadyuvante de la inflamación articular en este modelo K/BxN (Simarro et al., 2016).

Debido a la importancia de FASTK en el sistema inmunitario innato, en nuestro laboratorio se han llevado a cabo ensayos en otras funciones macrofágicas como la fagocitosis opsónica y no opsónica, y sobre la eliminación intracelular de bacterias. Mediante un estudio previo se han explorado ambos tipos de fagocitosis, y se determinó que la ausencia de FASTK provoca un aumento en la capacidad fagocítica no opsónica de las bacterias Gram positivas (S.aureus) y Gram negativas (E.coli), mientras que la fagocitosis opsónica no estaba alterada (Figura 12A) (García del Río et al., 2018). También se demostró que la actividad bactericida en los macrófagos estimulados con las bacterias E.coli y S.aureus no estaba alterada en los macrófagos FASTK KO. A las 6 y 24 horas post-infección, el número de bacterias que sobreviven es similar en los macrófagos FASTK KO y WT (Figura 12B).

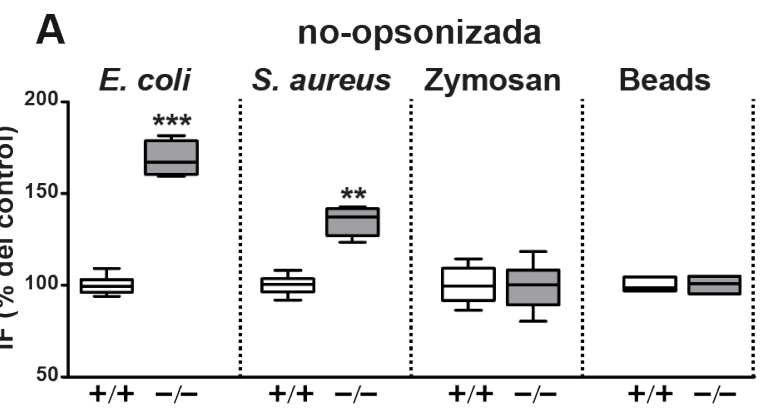

Ig-opsonizada

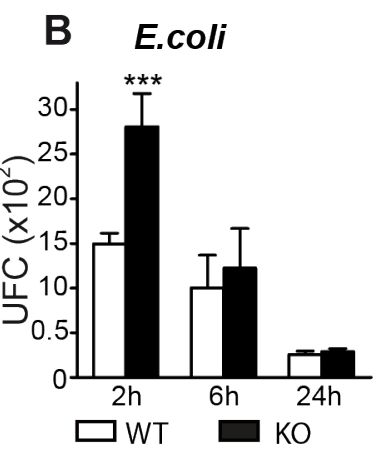

S.aureus
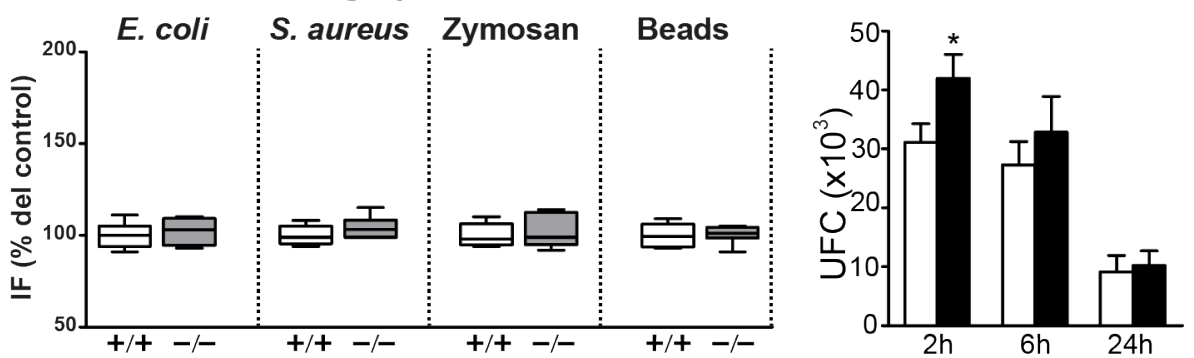

Figura 12. FASTK en la fagocitosis y actividad bactericida en macrófagos peritoneales WT y FASTK KO. A. La ausencia de FASTK provoca un aumento de la fagocitosis no opsónica en macrófagos peritoneales. Se utilizaron partículas inertes de látex (Beads) como control en la fagocitosis. B. La actividad bactericida de los macrófagos es independiente de FASTK. Imagen modificada de García del Río et al., 2018. 
Recientemente se ha analizado la actividad de los complejos de la cadena respiratoria mitocondrial en diferentes tejidos de ratón, en particular, en el músculo esquelético y cardíaco delecionados en la proteína FASTK, así como en la línea celular 143B deficiente en FASTK, y se ha observado, como ya hemos mencionado anteriormente, una reducción de la actividad del complejo I del 50 \% (Jourdain et al., 2015). En nuestro laboratorio se ha investigado que en los macrófagos murinos peritoneales FASTK KO tienen una disminución del $41.1 \%$ en la actividad del complejo I mitocondrial, mientras que la actividad de los otros complejos no se mostró alterada (Figura 13). Por consiguiente, la ausencia de la proteína FASTK induce un defecto en la actividad del complejo I mitocondrial, es decir, FASTK se requiere para la correcta actividad de este complejo de la cadena de transporte de electrones en los macrófagos, y por ello para una capacidad respiratoria normal (García del Río et al., 2018).

\begin{tabular}{lccl}
\multicolumn{4}{c}{ Actividad de los complejos mitocondriales (normalizados a la citrato sintasa) } \\
\hline \multicolumn{3}{c}{ WT } & FASTK KO \\
\hline Complejo I & $28.9 \pm 4.49(n=4)$ & $17.0 \pm 3.46(n=4)$ & $p=0.03$ \\
Complejo II & $49.5 \pm 13.54(n=3)$ & $52.0 \pm 13.04(n=3)$ & $n s$ \\
Complejo III & $188.9 \pm 6.68(n=3)$ & $192.9 \pm 5.47(n=3)$ & $n s$ \\
Complejo IV & $181.1 \pm 13.5(n=3)$ & $197.4 \pm 10.5(n=3)$ & $n s$
\end{tabular}

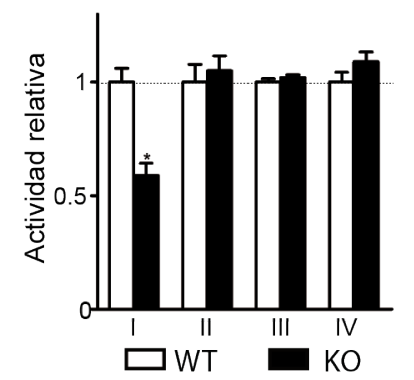

Figura 13. Análisis de la actividad enzimática mediante espectrofotometría mitocondrial en macrófagos peritoneales murinos WT y FASTK KO. En el gráfico de la derecha se representa la actividad relativa de los complejos mitocondriales en células WT y FASTK KO. Se representa el \% de cambio del KO respecto al WT, donde la media del WT es significativamente diferente de la media del $K O(p<0.05)$. En el panel de la izquierda se representan las actividades enzimáticas específicas del complejo I, II, III y IV que se normalizaron a la actividad citrato sintasa, y se expresan como ( $\mathrm{nmol} / \mathrm{min} / \mathrm{mg}$ de proteína) / (actividad especifica de citrato sintasa) $x$ 100. Los datos se representan como media \pm desviación estándar. Se indican el número de experimentos independientes y el valor $p$ utilizando la prueba de Mann Whitney. Imagen modificada de García del Río et al., 2018. 

OBJETIVOS 

En las secciones anteriores se han descrito las funciones de la proteína FASTK en la respuesta inmunitaria innata, gracias a la generación de ratones deficientes en esta proteína. En el trabajo previo realizado en el laboratorio se ha investigado la implicación que tienen los macrófagos deficientes en FASTK en la fagocitosis y la actividad bactericida. Por otro lado, se confirmó que FASTK regula la actividad del complejo I, tal y como lo hace en otros tejidos. Hemos tenido en cuenta estos hallazgos y nos planteamos estudiar el papel regulador del complejo I en la fagocitosis no opsónica de bacterias.

\section{OBJETIVOS}

El objetivo general de la presente tesis es estudiar si la función de FASTK sobre la actividad del complejo I es responsable de su papel en la fagocitosis no opsónica.

Para lograr este objetivo, se han propuesto los siguientes objetivos específicos:

1. Estudiar la fagocitosis no opsónica y la actividad bactericida mediante la inhibición farmacológica y genética del complejo I de la mitocondria, en los macrófagos estimulados con la bacteria Gram negativa Escherichia coli y la bacteria Gram positiva Staphylococcus aureus:

a. Inhibición farmacólogica con rotenona en los macrófagos peritoneales murinos de tipo salvaje.

b. Inhibición farmacológica con rotenona en la línea celular de macrófagos murina RAW 264.7.

c. Inhibición genética mediante la generación de dos líneas celulares deficientes en las subunidades del complejo I mitocondrial, NDUFS3 y NDUFS4, y de la línea celular deficiente para FASTK, a través del uso de shRNA en la línea celular RAW 264.7.

2. Realizar los ensayos de rescate mediante la readministración de la isoforma mitocondrial de FASTK como responsable de la fagocitosis no opsónica de la bacteria Gram negativa Escherichia coli y la bacteria Gram positiva Staphylococcus aureus.

3. Identificar los mecanismos moleculares por los que FASTK modula la fagocitosis no opsónica a través de la función alterada del complejo I. 

MATERIAL Y MÉTODOS 



\section{MATERIAL Y MÉTODOS}

\section{Líneas celulares y animales de experimentación}

La línea celular 293FT deriva de células embrionarias primarias de riñón humano, transformadas con el antígeno T grande del virus SV40 (SV40 large T antigen). Cuando un vector de expresión viral se cotransfecta en las células 293FT se producen altos niveles de RNA viral y de proteínas Rev y Gag/Pol necesarias para el encapsulamiento viral. Estas células expresan de manera estable el gen de resistencia a neomicina del pCMVSPORT6TAg.neo y deben ser mantenidas en un medio que contenga geneticina. La expresión de este gen de resistencia está controlada por el promotor SV40. Esta línea es de crecimiento rápido y presenta una morfología epitelial y propiedades adherentes en cultivo. Fue obtenida de la compañía Life Technologies.

La línea celular murina RAW 264.7 proviene de macrófagos murinos transformados con virus de leucemia murina de Abelson. Fue proporcionada por el laboratorio del Dr. Andrés Alonso (Instituto de Biología y Genética Molecular, Valladolid). Esta línea celular es fácil de cultivar, de alta eficiencia para la transfección de DNA, y sensible a la interferencia RNA. Las células tienen los receptores para la inmunoglobulina (FcRs) y complemento, y producen lisozima. Se utilizan en estudios metabólicos, de inflamación y apoptosis, entre otros, y para el estudio de la internalización y supervivencia de bacterias. Estas características hacen que sea una línea celular adecuada para el estudio de la fagocitosis.

Los macrófagos peritoneales de ratones C57BL/6J de tipo salvaje (WT) y deficientes en la proteína FASTK (KO), se obtuvieron tal y como se detalla en el apartado número 6 de Material y Métodos. Los ratones fueron alimentados y mantenidos en jaulas estériles en una habitación del animalario de la Facultad de Medicina de Valladolid con un ciclo de luz/oscuridad estándar (12 horas de luz/12 horas de oscuridad). Los ratones utilizados en el estudio fueron de 8 a 12 semanas de edad con un promedio de peso de 18-20 g. Todos los experimentos se llevaron a cabo tras la aprobación del Comité de Ética en Experimentación y Bienestar Animal (CEEBA) de la Universidad de Valladolid. Los ratones deficientes de la proteína FASTK (KO) fueron generados previamente en el laboratorio (Simarro et al., 2010b).

Las líneas celulares y los macrófagos peritoneales murinos fueron cultivados en medio de cultivo DMEM (Dulbecco's Modified Eagle Medium) (LONZA) suplementado con $10 \%$ de suero fetal bovino (FBS, Fetal Bovine Serum) (LONZA) inactivado por calor, 1X de Glutamax I (concentración final $2 \mathrm{mM}$ ) (Gibco), 1 \% de penicilina-estreptomicina (Gibco; concentración final de $100 \mathrm{U} / \mathrm{ml}$ y $100 \mu \mathrm{g} / \mathrm{ml}$, respectivamente). Nos referimos a este medio, como medio completo. 
La línea 293FT fue cultivada en medio completo al que se le añadió $1 \%$ de aminoácidos no esenciales (NEAA, Non-Essential Amino Acid) (Gibco) y geneticina a una concentración de $500 \mu \mathrm{g} / \mathrm{ml}$ (Gibco).

Las condiciones estándares de cultivo para todas las líneas celulares son de $37^{\circ} \mathrm{C}$ en atmósfera con $5 \%$ de $\mathrm{CO}_{2}$.

La viabilidad celular se evaluó por exclusión con azul de tripán al 0.4 \% (Gibco) y las células se contaron con la cámara de Neubauer utilizando el microscopio óptico.

\section{Cepas bacterianas}

- Escherichia coli DH5a, esta cepa bacteriana se obtuvo de Invitrogen (LifeTechnologies, Carlsbad, CA). Su genotipo es $\lambda-F-\Phi 80 l a c Z \Delta M 15$ $\Delta$ (lacZYA-argF) U169 recA1 endA1 hsdR17 (rK-, mK+) phoA supE44 $\lambda$ - thi1 gyrA96 relA1.

- Staphylococcus aureus Cowan 1, esta cepa bacteriana se obtuvo de la American Type Culture Collection (número de identificación ATCC 12598).

- Escherichia coli (DH5-alpha) y Staphylococcus aureus recombinante. Se obtuvieron introduciendo un plásmido pUC que lleva el gen de la proteína verde fluorescente o GFP (Green Fluorescence Protein) (resistente a cloranfenicol) en una bacteria competente. El plásmido fue proporcionado por el laboratorio de la Dra. Ana Abadía Molina (Universidad de Granada).

\section{Plásmidos}

Plásmido pGreen Puro: es un vector lentiviral de tercera generación derivado del HIV (Human Immunodeficiency Virus), de 7.861 bp. Se ha obtenido de System Biosciences. Se caracteriza por un casete génico de expresión de H1 que permite la transcripción constitutiva y eficiente por RNA polimerasa III de tránscritos de shRNA (short hairpain RNA) en una gama amplia de líneas celulares. También tiene un promotor CMV que permite niveles altos de expresión tanto del gen copGFP como del gen de resistencia a la puromicina (Figura 14) que codifica la enzima $\mathrm{N}$-acetil transferasa para seleccionar las células cuya transfección haya sido satisfactoria. $Y$ contiene también un promotor híbrido de RSV-5'LTR que proporciona niveles de expresión altos del constructo viral en las células 293FT, y se requiere para el empaquetamiento viral y la transcripción. Este vector necesita elementos genéticos para el empaquetamiento, la transducción y la integración estable en el genoma del huésped. Además, contiene un gen de resistencia a la ampicilina para su amplificación en bacterias. 


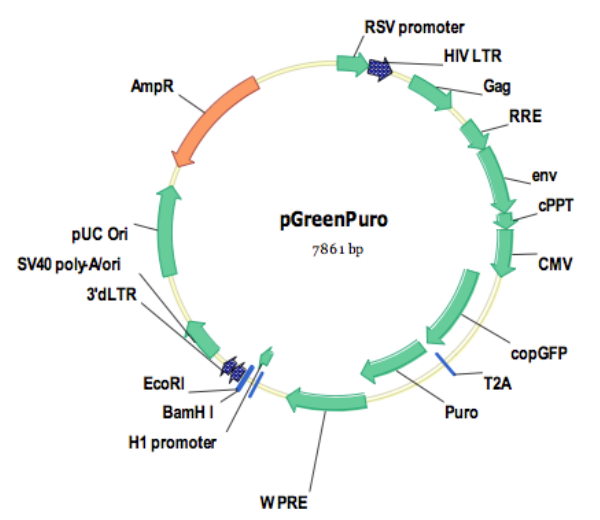

Figura 14. Mapa y características del vector (RSV/5'LTR, promotor; gag, señal de empaquetamiento; cPPT; promotor CMV; copGFP; T2A; Puro; WPRE; 3'ALTR; promotor H1 RNA; SV40 Poly-A, SV40 Ori, pUC Ori, AmpR).

Plásmido pMD2.G: es un plásmido de 5.824 bp, que se utiliza en la producción de lentivirus ya que posee un gen que codifica para la glicoproteína del virus de la estomatitis vesicular, VSV-G (Vesicular Stomatitis Virus Glycoprotein), una proteína involucrada en la formación de la envoltura viral. Además, posee un casete de resistencia a ampicilina que permite su selección para propagación en bacterias (Figura 15). Este plásmido fue desarrollado por el laboratorio del Dr. Didier Trono y obtenido de Addgene (Addgene plasmid \#12259).

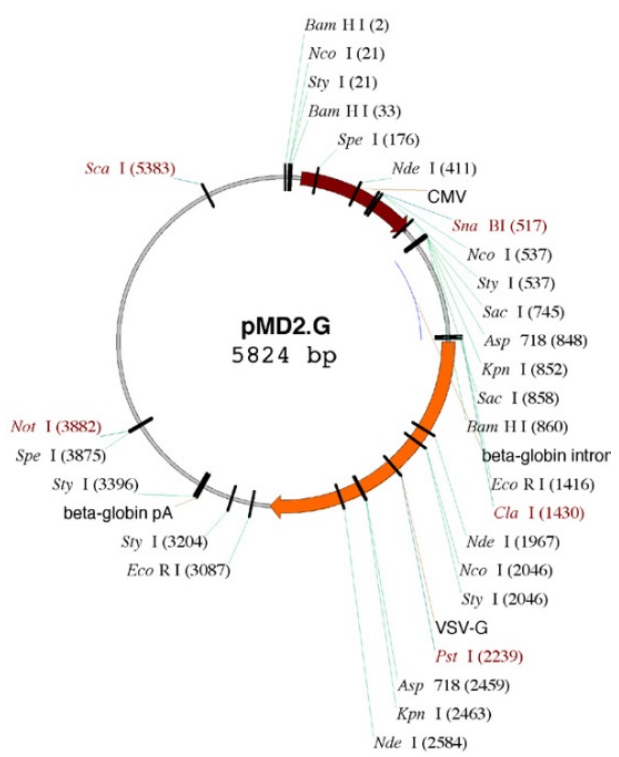

Figura 15. Representación del vector pMD2.G.

Plásmido psPAX2: Es un plásmido de 10.703 bp, que se utiliza en la producción de lentivirus de segunda generación. Tiene el promotor híbrido CAG que combina elementos de los promotores de citomegalovirus (CMV), de la $\beta$-actina de pollo y de la 
ß-globina de conejo que aumenta la eficiencia en la expresión de las proteínas de Gag, Pol, Tat y Rev del HIV-1, que también son codificadas por este plásmido y son necesarias para que se produzca el empaquetamiento de los lentivirus (Figura 16). Este plásmido fue desarrollado por el laboratorio del Dr. Didier Trono y obtenido de Addgene (Addgene plasmid \#12260).

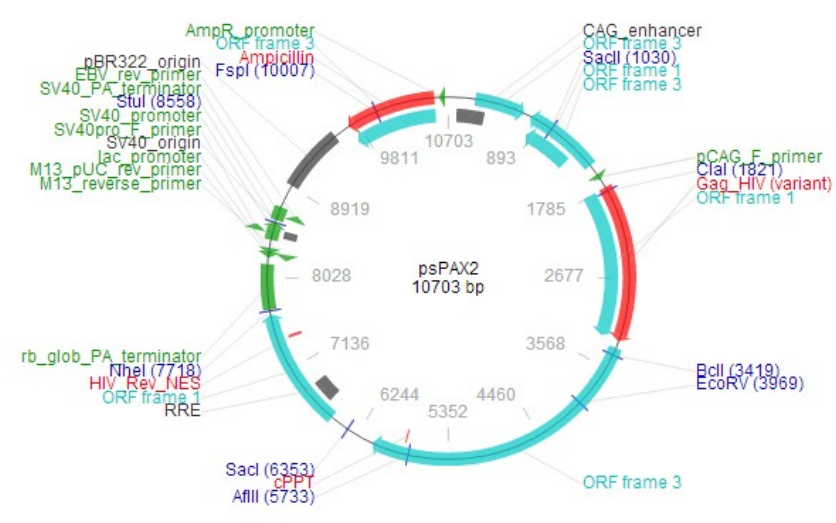

Figura 16. Representación del vector psPAX2.

Plásmido pDsRed1-RFP N1: es un vector de $4.7 \mathrm{~kb}$, que codifica una proteína fluorescente roja (RFP). Esta proteína RFP se aisló de una anémona de mar Discosoma sp. El MCS (Multiple Cloning Site) se encuentra entre el promotor temprano inmediato de CMV y la codificación de la secuencia DsRed1. El vector tiene un casete de resistencia a la neomicina, lo que permite que las células eucariotas transfectadas de manera estable se seleccionen utilizando geneticina, y un casete que confiere resistencia a la kanamicina $(30 \mu \mathrm{g} / \mathrm{ml})$ para su amplificación en E.coli. Este plásmido fue cedido por la Dra. Nancy Kedersha (Universidad de Harvard, Boston, MA).

\section{Oligonucleótidos}

\section{- Oligonucleótidos para la clonación en el vector pGreenPuro:}

Los oligonucleótidos diseñados para la clonación en el vector pGreenPuro se representan en la tabla 6 . Se utilizaron las enzimas de restricción BamHI y EcoRI. Los genes de interés utilizados para la interferencia de RNA en el presente estudio de investigación se especifican en la tabla 6, y el número de acceso a la secuencia asignada (Refseq) en los registros de secuencia de NCBI Reference Sequence (Refseq) fueron los siguientes: FASTK mouse (número de acceso Refseq NM_023229, https://www.ncbi.nlm.nih.gov/nuccore/NM 023229), NDUFS4 mouse (número de acceso Refseq NM_010887, https://www.ncbi.nlm.nih.gov/nuccore/NM 010887), NDUFS3 mouse (número de acceso Refseq NM_026688, 
https://www.ncbi.nlm.nih.gov/nuccore/NM 026688) y para 5'UTR Fastk (número de acceso Refseq NM_023229, https://www.ncbi.nlm.nih.gov/nuccore/NM 023229).

Tabla 6. Oligonucleótidos diseñados para la clonación en el vector pGreenPuro. En la tercera columna se representa en negrita la secuencia diana (target sequence).

\begin{tabular}{|l|l|l|l|}
\hline \multicolumn{1}{|c|}{ Gen } & Nombre de la secuencia & \multicolumn{1}{|c|}{ Secuencia (5' $\rightarrow$ 3') } & \multicolumn{1}{|c|}{$\begin{array}{c}\text { Secuencia } \\
\text { de inicio } \\
\text { del gen }\end{array}$} \\
\hline FASTK & FASTK mouse sense & $\begin{array}{l}\text { GATCC GTCAGCTCATCATCCGAAA } \\
\text { CTTCCTGTCAGA TTTCGGATGATGAGCTGAC } \\
\text { TTTTTG }\end{array}$ & 416 \\
\hline FASTK & FASTK mouse antisense & $\begin{array}{l}\text { AATTCAAAAA GTCAGCTCATCATCCGAAA } \\
\text { TCTGACAGGAAG TTTCGGATGATGAGCTGACG }\end{array}$ & 416 \\
\hline NDUFS4 & NDUFS4 mouse sense & $\begin{array}{l}\text { GATCC GCTATGATGTGGAAGAGAA } \\
\text { CTTCCTGTCAGA } \\
\text { TTCTCTTCCACATCATAGCTTTTTG }\end{array}$ & 431 \\
\hline NDUFS4 & NDUFS4 mouse antisense & $\begin{array}{l}\text { AATTCAAAAA GCTATGATGTGGAAGAGAA } \\
\text { TCTGACAGGAAG TTCTCTTCCACATCATAGCG }\end{array}$ & 431 \\
\hline NDUFS3 & NDUFS3 mouse sense & $\begin{array}{l}\text { GATCC GAGAGTATGTGGCTGAAAT } \\
\text { CTTCCTGTCAGA ATTTCAGCCACATACTCTC } \\
\text { TTTTTG }\end{array}$ & 182 \\
\hline NDUFS3 & NDUFS3 mouse antisense & $\begin{array}{l}\text { AATTCAAAAA GAGAGTATGTGGCTGAAAT } \\
\text { TCTGACAGGAAG ATTTCAGCCACATACTCTCG }\end{array}$ & 182 \\
\hline 5'UTR Fastk & 5' UTR Fastk mouse sense & $\begin{array}{l}\text { gatcCCTGGACTGCGATTGGCGTCTCttcctgtcagaA } \\
\text { GACGCCAATCGCAGTCCAGCttttg }\end{array}$ & 18 \\
\hline 5' UTR Fastk & $\begin{array}{l}\text { 5' UTR Fastk mouse } \\
\text { antisense }\end{array}$ & $\begin{array}{l}\text { gCGACCTGACGCTAACCGCAGAgaaggacagtctTCT } \\
\text { GCGGTTAGCGTCAGGTCGaaaaacttaa }\end{array}$ & 18 \\
\hline
\end{tabular}

\section{- Oligonucleótidos para el screening de pGreenPuro:}

Con los oligonucleótidos que se representan en la tabla 7 se comprobó que el inserto se había incorporado en el vector pGreenPuro.

Tabla 7. Oligonucleótidos utilizados para secuenciar por PCR.

\begin{tabular}{|l|l|l|}
\hline \multicolumn{1}{|c|}{ Gen } & Nombre de la secuencia & \multicolumn{1}{|c|}{ Secuencia $\left(\mathbf{5}^{\prime} \rightarrow \mathbf{3}^{\prime}\right)$} \\
\hline pGreenPuro & Seq pGreenPuro sense & AATGTCTTTGGATTTGGGAATCTTAT \\
\hline pGreenPuro & Seq pGreenPuro antisense & TGGTCTAACCAGAGAGACCCAGTA \\
\hline
\end{tabular}

\section{- Oligonucleótidos para qRT-PCR:}

En la tabla 8 se indican las secuencias de los genes FASTK, NDUFS3 y NDUFS4, y de los genes normalizadores $\beta$-actina y $18 \mathrm{~S}$ utilizados como control (housekeeping). El número de acceso a la secuencia asignada (Refseq) en los registros de secuencia de NCBI Reference Sequence (Refseq) para los genes $\beta$-actina y $18 \mathrm{~S}$ fueron los siguientes: $\beta$-actina mouse (número de acceso Refseq NM_007393, https://www.ncbi.nlm.nih.gov/nuccore/NM 007393) y para 18S ribosomal RNA mouse (número de acceso Refseq NR_003278, https://www.ncbi.nlm.nih.gov/nuccore/NR 003278). 
Tabla 8. Oligonucleótidos empleados para realizar la amplificación mediante qRT-PCR en las células RAW 264.7 transfectadas.

\begin{tabular}{|l|l|l|}
\hline \multicolumn{1}{|c|}{ Gen } & \multicolumn{1}{|c|}{ Nombre de la secuencia } & \multicolumn{1}{c|}{ Secuencia $\left(\mathbf{5}^{\prime} \rightarrow \mathbf{3}^{\prime}\right)$} \\
\hline FASTK & pRT-FASTK mouse sense & CTGGAAGCCATTGCTCATTTC \\
\hline FASTK & pRT-FASTK mouse antisense & CTCTCAAGGCAGGGCATAAA \\
\hline NDUFS4 & pRT-NDUFS4 mouse sense & TCTGACCTTCAGTGCCAAAG \\
\hline NDUFS4 & pRT-NDUFS4 mouse antisense & GTAGCCAGCTCCAACCTATTT \\
\hline NDUFS3 & pRT-NDUFS3 mouse sense & GATGAGCTGACACCCATTGA \\
\hline NDUFS3 & pRT-NDUFS3 mouse antisense & ATGTCCCTCGAAGCCATAATC \\
\hline $\boldsymbol{\beta}$-actina & pRT- $\beta$-actina mouse sense & $\begin{array}{l}\text { ACCAACTGGGACGACATGGAG } \\
\text { AAA }\end{array}$ \\
\hline $\boldsymbol{\beta}$-actina & pRT- $\beta$-actina mouse antisense & $\begin{array}{l}\text { TAGCACAGCCTGGATAGCAAC } \\
\text { GTA }\end{array}$ \\
\hline $\mathbf{1 8 S}$ & pRT-18S mouse sense & $\begin{array}{l}\text { TCAACTTTCGATGGTAGTCGC } \\
\text { CGT }\end{array}$ \\
\hline $\mathbf{1 8 S}$ & pRT-18S mouse antisense & $\begin{array}{l}\text { TCCTTGGATGTGGTAGCCGTT } \\
\text { TCT }\end{array}$ \\
\hline
\end{tabular}

\section{Genotipado de los ratones}

En primer lugar, se extrajo el DNA a partir de un fragmento pequeño (de 0.4 a $0.6 \mathrm{~cm}$ ) de las colas de los ratones C57BL/6J recién destetados. Para ello, las colas se incubaron en tampón de lisis (Tris $10 \mathrm{mM}$ a pH 7.5, EDTA $10 \mathrm{mM}, \mathrm{NaCl} 10 \mathrm{mM}, 0.5 \%$ de SDS y $300 \mu \mathrm{g} / \mathrm{ml}$ de proteinasa $\mathrm{K}$ ) durante 12 horas a $55^{\circ} \mathrm{C}$. El DNA se precipitó añadiendo al lisado $600 \mu \mathrm{l}$ de etanol absoluto y $20 \mu \mathrm{l}$ de $\mathrm{NaCl}$ a $5 \mathrm{M}$. Después se incubó la mezcla durante 20 minutos a $-20^{\circ} \mathrm{C}$ y se centrifugaron los viales a $14.000 \mathrm{rpm}$ durante 20 minutos. Se retiró el sobrenadante y el DNA genómico precipitado se lavó con etanol al $70 \%$. Las muestras se volvieron a centrifugar, se eliminó el sobrenadante y se dejaron secar los pellets durante 3-5 minutos a temperatura ambiente. Finalmente, el pellet de DNA se resuspendió en $100 \mu \mathrm{l}$ TE (Tris $10 \mathrm{mM}$ a pH 7.5 y EDTA $1 \mathrm{mM}$ ).

Para el genotipado de los ratones se realizó una PCR convencional empleando $2 \mu \mathrm{l}$ (generalmente entre 30-100 nanogramos) de DNA genómico en un volumen final de $25 \mu \mathrm{l}$. El DNA se amplificó mediante PCR con las siguientes condiciones para la amplificación: un ciclo de 2 minutos a $94^{\circ} \mathrm{C}$; y 32 ciclos de 15 segundos a $94^{\circ} \mathrm{C}, 30$ segundos a $58^{\circ} \mathrm{C}, 1$ minuto a $72^{\circ} \mathrm{C}$. Los oligonucleótidos utilizados se representan en la tabla 9. 
Tabla 9. Oligonucleótidos utilizados para el genotipado de los ratones de tipo salvaje (WT) y deficientes de FASTK (FASTK KO), para amplificar el alelo WT y FASTK KO.

\begin{tabular}{|c|c|}
\hline Nombre de la secuencia & Secuencia $\left(\mathbf{5}^{\prime} \rightarrow \mathbf{3}^{\prime}\right)$ \\
\hline WT sentido & GTGAATGACCTCAGGCTTAAC \\
\hline WT antisentido & AGAGAGCAGGATTCGAAGCAT \\
\hline KO sentido & CTCGAGGTCGACGGTATCGATA \\
\hline KO antisentido & AATCTTCACTGAGCGAGAAATG \\
\hline
\end{tabular}

El resultado de las amplificaciones se analizó en geles de agarosa al $1 \%(p / v$, peso/volumen), empleando $12 \mu \mathrm{l}$ de reacción junto con $3 \mu \mathrm{l}$ de loading buffer $6 \mathrm{X}$ (ver figura 17).

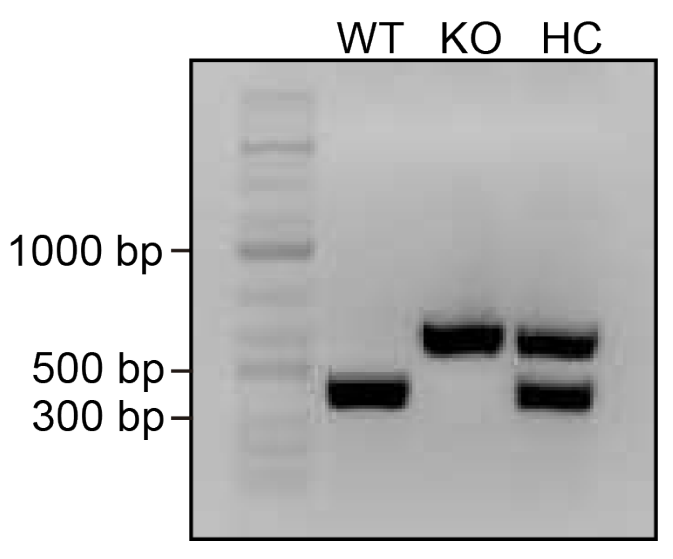

Figura 17. Imagen que muestra los resultados obtenidos de la comprobación del genotipo de ratones mediante PCR. Se utilizaron los oligonucleótidos que se indican en la tabla 9. Esperando obtener un amplificado de 669 bp para los ratones deficientes en la proteína FASTK (KO) y de 384 bp para los ratones de tipo salvaje (WT), mientras que en el heterocigoto (HC) se observan las dos bandas descritas amplificadas.

\section{Obtención de macrófagos peritoneales}

Los ratones se estimularon con $2 \mathrm{ml}$ del medio tioglicolato de Brewer estéril al $3 \%$ por vía intraperitoneal. Al quinto día de la inyección de tioglicolato, se anestesiaron con isofluorano y se sacrificaron por dislocación cervical. Posteriormente se recogió el exudado de células por lavado de la cavidad peritoneal con $8 \mathrm{ml}$ de medio completo a $4^{\circ} \mathrm{C}$. El exudado que se obtuvo se centrifugó a $1.200 \mathrm{rpm}$ durante 4 minutos. El pellet obtenido se resuspendió en $20 \mathrm{ml}$ de medio completo.

A continuación, la viabilidad celular se evaluó por exclusión con azul de tripán (Gibco) y las células se contaron con la cámara de Neubauer utilizando el microscopio óptico. La concentración de las células se ajustó a $5 \times 10^{5}$ macrófagos $/ \mathrm{ml}$ antes de realizar los experimentos (figura 18). 


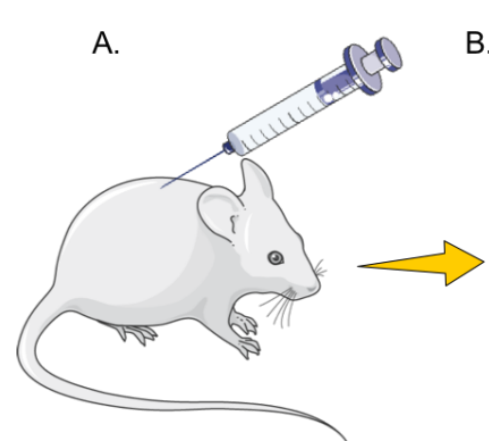

B.

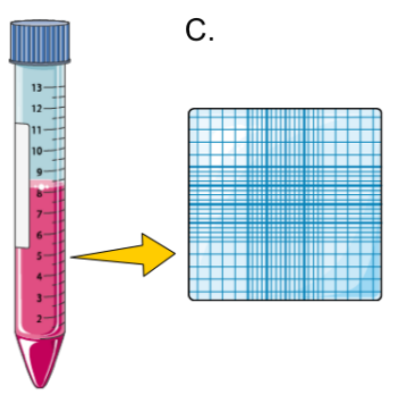

D.

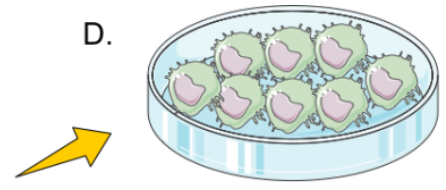

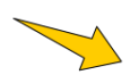

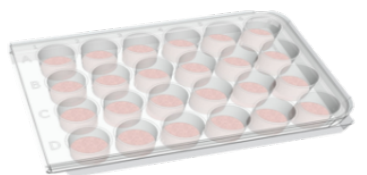

Figura 18. Esquema de la obtención de macrófagos peritoneales murinos. $\boldsymbol{A}$. Recogida del exudado de células por lavado de la cavidad peritoneal. B. Células resuspendidas en medio completo. C. Contaje de células en cámara de Neubauer para visualizar al microscopio.

D. Plaqueo de células en placas.

\section{Ensayo de fagocitosis in vitro en macrófagos}

Para estudiar la capacidad fagocítica in vitro de los macrófagos, se sembraron $5 \times 10^{5}$ células por pocillo sobre cubreobjetos de $12 \mathrm{~mm}$ en placas de 24 pocillos. Las cepas bacterianas que se emplearon fueron Escherichia coli $\mathrm{DH} 5 \alpha$ y Staphylococcus aureus Cowan 1, y Escherichia coli (DH5 $)$ y Staphylococcus aureus recombinante que expresan la proteína GFP. Las partículas inertes de látex (yellow-green FluoSpheres beads) (Molecular Probes, Thermo Fisher Scientific) (2.0 $\mu \mathrm{m}$ de diámetro) marcadas con fluoresceína se utilizan como control. También empleamos en este ensayo el zymosán (Sigma-Aldrich, número de producto Z4250). El zymosán es una preparación insoluble y particulada de la pared celular de la levadura Saccharomyces cerevisae. Se compone principalmente de $\beta(1-3)$ y $\beta(1-6)$ glucanos y $\alpha$-mananos, y de cantidades menores de quitina, proteínas y lípidos.

En primer lugar, se preparó la suspensión bacteriana, para ello se inocularon las bacterias durante 16 horas a $37^{\circ} \mathrm{C}$ en una placa de LB-agar sin antibiótico, mientras que las bacterias recombinantes que expresan GFP en una placa con cloranfenicol (10 $\mu \mathrm{g} / \mathrm{ml}$ ). Se tomaron colonias individuales de las cepas bacterianas mencionadas anteriormente, se cultivaron en agitación en $3 \mathrm{ml}$ de medio líquido LB a $37^{\circ} \mathrm{C}$ durante 12 horas a 200 rpm. Tras la incubación se midió la densidad óptica (DO) a 600 nm de una dilución del cultivo bacteriano. Una densidad óptica de 1 equivale aproximadamente a $10^{9}$ unidades formadoras de colonias (UFC)/ml en la cepa bacteriana de Staphylococcus aureus Cowan 1 , y a $8 \times 10^{8} \mathrm{UFC} / \mathrm{ml}$ para la cepa bacteriana de Escherichia coli $\mathrm{DH} 5 \alpha$.

En segundo lugar, se realizó la inactivación y tinción de las bacterias. Se transfirió el equivalente a $10^{9}$ UFC de cada cepa de bacterias y se centrifugó cada suspensión a $1.700 \mathrm{~g}$ durante 2 minutos a $4^{\circ} \mathrm{C}$. Se lavaron las bacterias dos veces en solución salina por centrifugación y después se eliminó el sobrenadante y se resuspendió cada cepa bacteriana en solución salina. Las bacterias se sometieron a 
$80^{\circ} \mathrm{C}$ durante 15 minutos para inactivarlas, se centrifugaron dos veces ( 2 minutos a $12.000 \mathrm{~g}$ ) con lavados en PBS, y se incubaron con $0.1 \mathrm{mg} / \mathrm{ml}$ de solución de fluorocromo en PBS, FITC (Fluorescein-5-(6) isothiocyanate) (Sigma-Aldrich) ó TRITC (Tetramethylrhodamine-5 (and-6)-isothiocyanate) (Thermo Fischer Scientific), protegiéndolo de la luz, a $37^{\circ} \mathrm{C}$ durante 30 minutos. Finalmente se lavaron tres veces con PBS antes de utilizarlas.

Las bacterias inactivadas teñidas se resuspendieron en DMEM, sin fetal ni penicilina/estreptomicina, a una concentración de $1 \times 10^{8} / \mathrm{ml}$ para el ensayo de fagocitosis.

A continuación se incubaron los macrófagos con las bacterias en una relación 50:1 bacterias:macrófago, durante 60 minutos, se lavaron 3 veces los pocillos con PBS frío y se añadió $500 \mu \mathrm{l}$ de una solución azul de tripán al $0.4 \%(0.2 \mathrm{mg} / \mathrm{ml})$ (Gibco) para eliminar la señal fluorescente de las bacterias extracelulares. Las células se fijaron con paraformaldehído al $3.7 \%$ en PBS durante 10 minutos a temperatura ambiente y se lavaron tres veces con PBS. Los cubres se montaron sobre portaobjetos con medio de montaje. Finalmente, las bacterias fagocitadas se contaron en un microscopio de fluorescencia.

La cuantificación de la fagocitosis se caracteriza midiendo manualmente sobre el campo de observación en el microscopio, y se cuantifican alrededor de 100 macrófagos elegidos al azar por condición. Se calculó el índice fagocítico (IF) multiplicando el porcentaje de células que han fagocitado por la media de bacterias fagocitadas por célula.

Este ensayo se realizó para los macrófagos peritoneales murinos de tipo salvaje, macrófagos de tipo salvaje con la adición de rotenona (30 nM) (Sigma-Aldrich), macrófagos FASTK KO, la línea celular murina RAW 264.7, la línea celular murina RAW 264.7 tratada con rotenona, y las células silenciadas en FASTK (shFASTK), y en las dos subunidades del complejo I generadas: NDUFS3 (shNDUFS3) y NDUFS4 (shNDUFS4).

\section{Ensayos de la actividad bactericida}

La actividad bactericida de los macrófagos se midió usando el ensayo de protección con gentamicina (Laroux et al., 2005). Es un ensayo de supervivencia bacteriana dentro del macrófago. Los macrófagos se sembraron en placas de 24 pocillos a una concentración de $5 \times 10^{5}$ células por pocillo por triplicado para condición y punto de tiempo. Las células se incubaron con bacterias en una relación 10:1 de bacterias:macrófago durante 1 hora a $37^{\circ} \mathrm{C}$ para permitir la fagocitosis. Después de este tiempo de incubación las bacterias extracelulares no adherentes se eliminaron mediante 
lavados con PBS, y se añadió la gentamicina al medio $(100 \mu \mathrm{g} / \mathrm{ml})$ durante 1 hora para eliminar las bacterias extracelulares adherentes. A las 2 horas, el medio se reemplazó por medio nuevo que contenía $10 \mu \mathrm{g} / \mathrm{ml}$ de gentamicina. A las 2, 6 y 24 horas, las células se lavaron con PBS para eliminar los residuos de gentamicina y se lisaron con agua estéril durante 15 minutos a temperatura ambiente. Se plaquearon varias diluciones del lisado celular en placas de agar Luria Bertani (Lennox) y se contaron las colonias crecidas (bacterias intracelulares viables) después de la incubación durante la noche a $37^{\circ} \mathrm{C}$.

En este experimento, los recuentos bacterianos en los puntos tempranos del ensayo ( 2 horas) reflejan la capacidad fagocítica. Mientras que los recuentos bacterianos en los tiempos 6 y 24 horas reflejan la capacidad bactericida.

\section{Determinación de los radicales libres de oxígeno}

\subsection{Quimioluminiscencia (reacción del luminol)}

Para determinar la producción de radicales libres de oxígeno, se utilizó el ensayo con luminol. El luminol es una sustancia permeable a las células que detecta los radicales dentro y fuera de la célula. En presencia de un oxidante, en este caso los iones de oxígeno y peróxidos que se generan durante el estallido oxidativo, el luminol se oxida por la adición de la peroxidasa de rábano picante (HRP, horseradish peroxidase). La quimioluminiscencia se detectó en $323 \mu$ de muestra que contenían $2 \times 10^{5}$ macrófagos, $200 \mu \mathrm{M}$ luminol (Thermo Fisher Scientific) y $16 \mathrm{U}$ de HRP (Sigma-Aldrich) en una placa del luminómetro (Appliskan, Thermo Fisher Scientific). Las sustancias estimulantes fueron zymosán, E.coli y S.aureus, en una proporción bacteria ó zymosán a célula 100:1. Se realizó una preincubación durante 30 minutos a $37^{\circ} \mathrm{C}$ en las situaciones en las que se empleaba el inhibidor rotenona (30 nM) (Sigma-Aldrich), y una incubación de 10 minutos a $37^{\circ} \mathrm{C}$ con luminol y HRP antes de iniciar la lectura en el luminómetro. Posteriormente se añadieron las bacterias y el zymosán, y se realizó la lectura cada cinco minutos durante 45 minutos.

\subsection{Citometría de flujo (MitoSoX Red)}

Los niveles $\mathrm{O}_{2}^{-}$mitocondriales se determinaron empleando la sonda fluorescente Mitosox Red (Molecular Probes, Thermo Fisher Scientific). Es un colorante fluorógeno, derivado de hidroetidina, que se incorpora a las células vivas, y produce fluorescencia roja cuando se oxida con el anión superóxido dentro de la mitocondria. Para ello las células se incubaron en presencia de $2.5 \mu \mathrm{M}$ de MitoSOX Red y fueron estimuladas con las bacterias durante 15 minutos a $37^{\circ} \mathrm{C}$. 
La fluorescencia se determinó mediante citometría de flujo utilizando el citómetro Gallios Beckman Coulter en el Servicio de Citometría de Flujo del Instituto de Biología y Genética Molecular. MitoSOX Red se excitó a 488 nm y la emisión de fluorescencia se midió a $575 \mathrm{~nm}$. La intensidad de la fluorescencia se expresó en escala logarítmica. Fueron analizadas un mínimo de 10.000 células.

\section{Clonación en vectores de expresión}

\subsection{Digestión del vector y anillamiento de oligonucleótidos}

Se llevó a cabo la digestión de $2 \mu \mathrm{g}$ del plásmido pGreenPuro siguiendo el protocolo de la casa comercial del vector, con $0.5 \mu \mathrm{l}$ de las enzimas de restricción EcoRI y BamHI (20U/ $\mu \mathrm{l}$, NEB), $33.8 \mu \mathrm{l}$ de $\mathrm{H}_{2} \mathrm{O}, 5 \mu \mathrm{l}$ 10x NEB 3 buffer y $0.2 \mu \mathrm{l}$ 100x BSA (Bovine Serum Albumin), durante dos horas a $37^{\circ} \mathrm{C}$. A partir de la electroforesis en gel de agarosa se cortó la banda obtenida, se purificó utilizando el kit de purificación QIAquick PCR (Qiagen) y se cuantificó mediante el espectrofotómetro de microvolúmenes (NanoDrop, Thermo Fisher Scientific).

Los oligonucleótidos se disolvieron en $\mathrm{H}_{2} \mathrm{O}$ hasta una concentración final de $20 \mu \mathrm{M}$, y se realizó la reacción de anillamiento o annealing, reacción mediante la cual las secuencias complementarias del DNA o RNA de cadena simple se unen mediante enlaces puentes de hidrógeno, formando una cadena doble. Para ello se llevó a cabo la reacción de anillamiento en un volumen final de $20 \mu$ l: se empleó $1 \mu \mathrm{l}$ de cada uno de los oligonucleótidos sentido y antisentido (concentración final de $1 \mu \mathrm{M}$ cada oligonucleótido) y $18 \mu \mathrm{l}$ del tampón de anillamiento (10 mM Tris, $50 \mathrm{mM}$ de $\mathrm{NaCl}, 1 \mathrm{mM}$ EDTA). Se desnaturalizó la mezcla de reacción durante 2 minutos a $95^{\circ} \mathrm{C}$ y se dejó enfriar lentamente a temperatura ambiente durante 30 minutos. Una vez que finalizó la reacción, la muestra se diluyó 1:20 en tampón 1X TE (10 mM Tris-HCl y 1 mM EDTA) o $\mathrm{H}_{2} \mathrm{O}$ libre de nucleasas para continuar con la reacción de ligación.

\subsection{Reacción de ligación}

Para realizar una ligación, se usó el DNA del vector digerido e inserto/s. La relación molar del DNA vector con respecto al DNA del inserto fue de 1:3. Se utilizó el kit de ligación Rapid DNA Dephos and Ligation Kit de Roche.

Para llevar a cabo la reacción de ligación, en el primer paso se mezclaron el DNA del vector y el DNA del inserto en el tampón de dilución (5X DNA dilution buffer). Esto se llevó a cabo en un volumen final de $10 \mu \mathrm{l}$, que se ajustó con $\mathrm{H}_{2} \mathrm{O}$ ultrapura. A continuación, se añadieron $10 \mu$ del tampón de ligación (2X T4 DNA ligation buffer) y se mezcló. Por último, se añadió $1 \mu$ de la enzima ligasa (T4 DNA ligase) y se incubó 
durante $15 \min$ a temperatura ambiente. La reacción de ligación se utilizó inmediatamente para transformar en bacterias termocompetentes, o bien, se almacenó a $-20^{\circ} \mathrm{C}$ hasta su uso.

\subsection{Preparación de bacterias Escherichia coli DH5 $\alpha$ químicamente competentes}

A partir de la cepa comercial, se obtuvieron en el laboratorio bacterias Escherichia coli $\mathrm{DH} 5 \alpha$ químicamente competentes. En primer lugar, se sembraron las bacterias comerciales en una placa de LB-agar sin antibiótico, incubándose durante 16 horas a $37^{\circ} \mathrm{C}$. Después se picó una colonia aislada y se cultivó en $2 \mathrm{ml}$ de medio líquido LB durante 16 horas a $37^{\circ} \mathrm{C}$ en agitación. Una vez transcurrido este tiempo se inoculó 1 $\mathrm{ml}$ de este cultivo en $50 \mathrm{ml}$ de LB líquido y se incubó de nuevo a $37^{\circ} \mathrm{C}$ en agitación hasta obtener una densidad óptica (DO) a 600 nm de 0.4 a 0.6. A continuación, se centrifugó el cultivo bacteriano a $4.000 \mathrm{rpm}$ durante 5 minutos a $4^{\circ} \mathrm{C}$. Se descartó el sobrenadante y se resuspendió el pellet de bacterias en $15 \mathrm{ml}$ de tampón CMG (50 mM CaCl 2 y 50 $\mathrm{mM} \mathrm{MgCl} 2$ ), y se incubó durante 15 minutos en hielo. Tras la incubación, la suspensión bacteriana se centrifugó en las mismas condiciones mencionadas anteriormente. Se descartó el sobrenadante y el pellet bacteriano se resuspendió en $3.6 \mathrm{ml}$ de tampón CMG y se incubó de nuevo en hielo durante 5 minutos. Finalmente se añadieron $250 \mu \mathrm{l}$ de DMSO y se incubó por última vez en hielo durante 5 minutos. Las bacterias competentes obtenidas se almacenaron en alícuotas a $-80^{\circ} \mathrm{C}$.

\subsection{Transformación bacteriana}

Para realizar la transformación bacteriana, se descongelaron las bacterias Escherichia coli DH5 $\alpha$ químicamente competentes en hielo. Se añadieron $50 \mathrm{ng}$ de plásmido o $2 \mu \mathrm{l}$ del producto de ligación (10-30 ng) a $50 \mu \mathrm{l}$ de bacterias competentes. Se dejó la mezcla en hielo 20 minutos. Pasado este tiempo de incubación, la mezcla se sometió a un choque térmico de 55 segundos a $43^{\circ} \mathrm{C}$. Luego se incubó la muestra otros 2 minutos en hielo, se añadió $1 \mathrm{ml}$ de LB líquido y se incubó 1 hora a $37^{\circ} \mathrm{C}$ en agitación. Posteriormente, se centrifugó la muestra 2 minutos a $12.000 \mathrm{rpm}$ y se retiraron $850 \mu \mathrm{l}$ del sobrenadante. Se resuspendió el pellet bacteriano, que se sembró en placa de LB agar en presencia del antibiótico de selección: ampicilina $(50 \mu \mathrm{g} / \mathrm{ml})$ cloranfenicol $(10 \mu \mathrm{g} / \mathrm{ml})$ o kanamicina $(30 \mu \mathrm{g} / \mathrm{ml})$. Las placas de cultivo se incubaron a $37^{\circ} \mathrm{C}$ durante 12-16 horas. 


\subsection{Purificación de plásmidos a pequeña escala (miniprep)}

Se tomaron colonias aisladas de una placa de LB agar en presencia del antibiótico de selección, se cultivaron en $2 \mathrm{ml}$ de medio LB líquido en presencia del mismo antibiótico durante toda la noche a $37^{\circ} \mathrm{C}$ en agitación. El pellet bacteriano obtenido mediante la centrifugación del cultivo se resuspendió en $100 \mu \mathrm{l}$ de buffer de resuspensión (50 mM Tris y 10 mM EDTA, pH 8.0). Luego, se añadieron $100 \mu$ lde buffer de lisis $(0,1 \mathrm{M} \mathrm{NaOH}$ y $1 \% \mathrm{SDS})$, se mezclaron los viales por inversión para mezclar las soluciones y se incubaron 4 minutos a temperatura ambiente. Transcurrido este tiempo, se añadieron $100 \mu \mathrm{l}$ de buffer neutralizador (1.5 M de acetato potásico, $\mathrm{pH} 5.5$ ), se mezcló nuevamente por inversión y se centrifugó 5 minutos a 15.000 rpm. Se recogió el sobrenadante y se añadieron $900 \mu \mathrm{l}$ de etanol absoluto (100 \%) frío para precipitar el DNA plasmídico. Se invirtieron los viales para mezclar las soluciones y se incubaron durante 10 minutos a $-20^{\circ} \mathrm{C}$. Finalmente, se centrifugaron los viales a $15.000 \mathrm{rpm}$ durante 10 minutos, tras lo cual se retiró el sobrenadante y se añadió sobre el pellet 700 $\mu \mathrm{l}$ de etanol al $70 \%$. Se centrifugaron de nuevo los viales a $15.000 \mathrm{rpm}$ durante 5 minutos, se retiró el sobrenadante y se dejó secar el pellet durante 5 minutos a temperatura ambiente. Por último, se resuspendió el DNA plasmídico en $50 \mu \mathrm{l}$ de TE 1X y se empleó el espectrofotómetro NanoDrop (Thermo Fischer) para su cuantificación.

\subsection{Purificación de plásmidos a mediana escala (midiprep)}

La extracción de plásmido a mediana escala se realizó utilizando el kit comercial PureLink $^{\mathrm{TM}}$ HiPure Plasmid Filter Midiprep Kit (Invitrogen). El principio de este kit se basa en la lisis alcalina de las bacterias, seguido por la adsorción del DNA a una membrana de sílica presente en una columna. Esta columna separa el DNA del resto de la muestra.

Las bacterias procedentes de $100 \mathrm{ml}$ de cultivo se resuspendieron en $4 \mathrm{ml}$ de tampón R3 (tampón de resuspensión). A continuación, se añadieron $4 \mathrm{ml}$ de tampón L7 (tampón de lisis), se mezclaron las soluciones mediante inversión y se incubaron 5 minutos a temperatura ambiente. Después se añadieron $4 \mathrm{ml}$ de tampón N3 (tampón neutralizador), se invirtieron los viales de nuevo para mezclar las soluciones. Posteriormente se centrifugaron a $12.000 \mathrm{rpm}$ durante 10 minutos a $4^{\circ} \mathrm{C}$. Se añadió el sobrenadante a una columna de sílica previamente equilibrada con $10 \mathrm{ml}$ de tampón EQ1 (tampón equilibrador). Cuando el líquido atravesó la membrana, la columna se lavó con $10 \mathrm{ml}$ de tampón W8 (tampón de lavado). El DNA se eluyó con $5 \mathrm{ml}$ de tampón E4 (tampón de elución), se precipitó añadiendo $3.5 \mathrm{ml}$ de isopropanol, y se centrifugó 30 minutos a $9.500 \mathrm{rpm}$. El precipitado obtenido se lavó con etanol al 70 \%, y se volvió a 
centrifugar para eliminar los restos del alcohol. Finalmente, se resuspendió el DNA en $\mathrm{TE}$, se cuantificó y almacenó a $-20^{\circ} \mathrm{C}$.

\section{RNA de interferencia}

Para reducir la expresión específica de ciertas proteínas se emplearon shRNAs en las células RAW 264.7 (ver secuencias en tabla 6). Los insertos se clonaron en el vector pGreenPuro (System Biosciences), en los sitios de restricción BamHI/EcoRI de acuerdo a las instrucciones del fabricante, y como se ha detallado en el apartado 10 de Material y Métodos. Se comprobaron los insertos de shRNA a través de PCR y mediante el análisis por secuenciación de los productos de PCR positivos con los oligonucleótidos especificados en la tabla 7. El programa de PCR que se utilizó: un ciclo a $94^{\circ} \mathrm{C}, 4 \mathrm{~min}$; 25 ciclos a $94^{\circ} \mathrm{C}, 0.5 \mathrm{~min}$ y $68^{\circ} \mathrm{C}, 1 \mathrm{~min}$; y 1 ciclo a $68^{\circ} \mathrm{C}, 2 \mathrm{~min}$. El producto de PCR se visualizó en un gel de agarosa al $3 \%$ de agarosa.

\subsection{Producción y transducción de lentivirus}

Se produjeron los lentivirus a través de una co-transfección en la línea celular 293FT (Thermo Fisher Scientific) con el plásmido lentiviral de interés (los shRNAs diseñados se indican en la tabla 6) y los plásmidos de empaquetamiento (psPAX2 y pMD2.G), mediante el uso de TransIT X2 (Mirus Bio LLC). Se cambió el medio de cultivo a las células cultivadas en placas de seis pocillos $\left(9.5 \mathrm{~cm}^{2}\right)$ con una confluencia del $80 \%$ media hora antes de la transfección por medio completo sin antibiótico. Se formó el complejo de transfección utilizando $500 \mu \mathrm{l}$ de Opti-MEM mezclándolo con $22.5 \mu \mathrm{g}$ de DNA total $(5 \mu \mathrm{g}$ de pMD2.G, $7.5 \mu \mathrm{g}$ de psPAX-2 y $10 \mu \mathrm{g}$ del plásmido de transferencia que hemos generado), con $45 \mu$ de TransIT X2 de acuerdo a las instrucciones del fabricante, y se dejó incubando la mezcla durante 20 minutos a temperatura ambiente para la formación de los complejos. A continuación, se añadió la mezcla a las células $293 \mathrm{FT}$ en cultivo y se incubaron durante toda la noche a $37^{\circ} \mathrm{C}$ a $7 \% \mathrm{CO}_{2}$. Tras la incubación, se cambió el medio de las placas por DMEM suplementado con NEAA y las células se mantuvieron en cultivo 48 horas más para facilitar la acumulación del lentivirus en el sobrenadante. Se recogieron los sobrenadantes virales a las 48-72 horas después de la transfección, se centrifugaron a $1.500 \mathrm{rpm}$ durante 5 minutos y luego se pasaron a través de un filtro de $0.45 \mu \mathrm{m}$.

El título lentiviral obtenido osciló según los diferentes experimentos entre $10^{6}-10^{8}$ partículas virales/ml lo que coincide con el rendimiento obtenido por otros autores (Kutner et al., 2009; Tang et al., 2015).

Las células diana RAW 264.7 se transdujeron cuando estaban a una confluencia del $80 \%$ y en presencia de polibreno $(5 \mu \mathrm{g} / \mathrm{ml})$. La selección en las células RAW 264.7 
fue con puromicina $(7 \mu \mathrm{g} / \mathrm{ml})$ durante dos semanas. La integración de los vectores lentivirales que codifican para shRNAs se monitorizó mediante el microscopio de fluorescencia, ya que coexpresan GFP, y también a través de la separación celular por citometría (o cell sorting) con el citómetro FACS Aria (BD Biosciences). Se midió el nivel de silenciamiento para cada uno de los shRNA mediante qRT-PCR (utilizando los oligonucleótidos especificados en la tabla 8).

\subsection{Rescate del fenotipo}

Los experimentos de silenciamiento se habían hecho con shRNAs dirigidos a la región 5' no traducida de FASTK (Tabla 6) en las células RAW 264.7 y se expresaron en vectores lentivirales, como se ha explicado en el apartado anterior. El silenciamiento del mRNA de FASTK se verificó mediante RT-qPCR. Tras la generación de las células silenciadas en FASTK mediante shRNA contra la región UTR, se realizaron las transfecciones para sobreexpresar FASTK (el cDNA sobreexpresado no posee la región 5'UTR por lo que no es afectado para los shRNA) con TransIT X2, cada DNA plasmídico y Opti-MEM. Esta mezcla de transfección se incubó en las células durante 24 horas. Los DNA plasmídicos utilizados en esta transfección transitoria fueron: el vector RFP (pDsRed1-N1, Clontech), FASTK WT fusionado con RFP y FASTK delecionado en los primeros 34 aminoácidos y que comienza en la metionina interna posición 35 (M35) cedidos por la Dra. Nancy Kedersha (Universidad de Harvard, Boston, MA). Las células transfectadas se seleccionaron con $1 \mathrm{mg} / \mathrm{ml}$ de G418 (Sigma-Aldrich) y la expresión de RFP se comprobó utilizando el microscopio de fluorescencia.

\section{Aislamiento de RNA, síntesis de cDNA y PCR cuantitativa a tiempo real (qRT- PCR)}

\subsection{Extracción de RNA}

La extracción de RNA total se llevó a cabo empleando el reactivo TRIzol (Life Technologies). El TRIzol es un reactivo a base de fenol e isotiocianato de guanidina que mantiene la integridad del RNA mientras se lisan las células y se disuelven el resto de componentes celulares. Se añadió $1 \mathrm{ml}$ de TRIzol a las células (aproximadamente por cada $5-10 \times 10^{6}$ células), se pipetearon las muestras y se incubaron durante 5 minutos a temperatura ambiente para permitir la disociación completa de los complejos nucleoproteicos. Se añadieron $200 \mu$ de cloroformo por cada mililitro de TRIzol, se agitaron los tubos durante 15 segundos y se incubaron durante 2 ○ 3 minutos. Posteriormente se centrifugaron las muestras a $12.000 \mathrm{~g}$ durante 15 minutos a $4^{\circ} \mathrm{C}$, observando dos fases: la fase superior o fase acuosa donde se encuentra el RNA, la inferior roja que pertenece al fenol y cloroformo, y una interfase entre ambas que 
contiene el DNA y las proteínas. Se transfirieron cada una de las fases acuosas a tubos nuevos. El RNA se precipitó mezclándolo con isopropanol (500 $\mu \mathrm{l})$, se incubaron las muestras a temperatura ambiente durante 10 minutos y se centrifugaron a $12.000 \mathrm{~g}$ durante 10 minutos a $4^{\circ} \mathrm{C}$. El precipitado de RNA formó un pellet, se lavó con $1 \mathrm{ml} \mathrm{de}$ etanol al $75 \%$ y se dejó secar unos 5-10 minutos. EI RNA total se resuspendió en agua libre de ribonucleasas, con DNasa (Ambion) para eliminar posibles restos de DNA contaminante y se almacenó a $-80^{\circ} \mathrm{C}$ para su posterior uso. La concentración y pureza del RNA fueron determinadas con el Nanodrop (Thermo Scientific), utilizando la relación de absorbancias A260/280.

\subsection{Síntesis de cDNA}

La reacción de transcripción inversa, retrotranscripción del mRNA a cDNA, se llevó a cabo partiendo de $0.5 \mu \mathrm{g}$ de RNA total, con el kit de síntesis iScript cDNA (Bio-Rad) siguiendo las instrucciones del fabricante. En el tubo de PCR mezclamos el RNA, $4 \mu \mathrm{l}$ de buffer $5 \mathrm{X}$ (incluye los oligonucleótidos poli-dT que hibridan con las secuencias poli(A) de los mRNAs y hexanucleótidos degenerados), $1 \mu \mathrm{l}(200 \mathrm{U} / \mu \mathrm{l})$ de transcriptasa reversa (retrotranscriptasa) del virus de la leucemia murina de Moloney (MMLV, Moloney Murine Leukemia Virus) y $\mathrm{H}_{2} \mathrm{O}$ hasta completar $10 \mu \mathrm{l}$. Los tubos se incubaron primero a $25^{\circ} \mathrm{C}$ durante 5 minutos, y luego a $42^{\circ} \mathrm{C}$ durante 30 minutos para permitir la transcripción inversa del RNA, seguido de $85^{\circ} \mathrm{C}$ durante 5 minutos para desnaturalizar la enzima retrotranscriptasa. El cDNA se conserva a $-80^{\circ} \mathrm{C}$ hasta su uso.

\section{3. $P C R$ cuantitativa a tiempo real (qRT-PCR)}

La determinación de los niveles de expresión de mRNA se realizó mediante la técnica de qRT-PCR. Para ello se utilizó el kit comercial SYBR Green Supermix (Bio-Rad) siguiendo las especificaciones del fabricante. Las amplificaciones se hicieron en un volumen final de $25 \mu$ por pocillo en placas de 96 pocillos: $5 \mu$ del cDNA (10 ng de RNA/ $\mu \mathrm{l}), 12.5 \mu \mathrm{l}$ de la mezcla SYBR Green, $1 \mu \mathrm{l}$ de la mezcla de cebadores sentido y antisentido (cada uno a una concentración de $10 \mathrm{pmol} / \mu \mathrm{l}$ ) y $\mathrm{H}_{2} \mathrm{O}$ hasta completar el volumen de $25 \mu \mathrm{l}$.

Las condiciones que se siguieron fueron 1 ciclo de 1 minuto a $95^{\circ} \mathrm{C}$ y 40 ciclos de 15 segundos a $95^{\circ} \mathrm{C}, 30$ segundos a $60^{\circ} \mathrm{C}$ y 40 segundos a $72^{\circ} \mathrm{C}$. Los experimentos se diseñaron para comparar los niveles relativos de cada tránscrito. Los cambios en la expresión génica relativos se determinaron usando el método $2^{-\Delta \Delta C T}$, y las cuantificaciones se han referido a la expresión de los genes $18 \mathrm{~S}$ o $\beta$-actina (housekeeping genes ó genes normalizadores) (Tabla 8). Se llevaron a cabo tres 
réplicas de PCR independientes para todos los genes de interés en el aparato LightCycler 480 (Roche). Los análisis de la curva de fusión se realizaron al final de cada lectura para garantizar que solo se amplificara un producto.

\section{Ensayos de apoptosis y viabilidad celular}

Para analizar la fragmentación del DNA celular se empleó la técnica TUNEL (Terminal deoxyribonucleotidyl transferase mediated dUTP Nick End Labeling). Es un método basado en detectar la aparición de los extremos 3'-OH libres, como consecuencia de la fragmentación del DNA celular durante la apoptosis, con nucleótidos dUTP (Deoxyuridine Triphosphate) fluoresceinados por medio de la enzima desoxirribonucleotidil transferasa terminal (TdT, Terminal deoxynucleotidyl transferase).

Se llevó a cabo con el kit comercial In situ Cell Death Detection Kit (Roche) según las instrucciones del fabricante. En este ensayo se partió de los macrófagos peritoneales murinos de tipo salvaje. Estas células fueron tratadas con rotenona ( $30 \mathrm{nM}, 24$ horas), y para inducir la apoptosis los macrófagos se irradiaron a $100 \mathrm{~mJ} / \mathrm{cm}^{2}$ utilizando un Stratalinker 2400 (Stratagene), y se incubaron durante 4 horas. Una vez concluido el experimento, las células cultivadas sobre cubres de vidrio se fijaron con la solución de fijación con paraformaldehído al $4 \%$ durante 20 minutos a $15-25^{\circ} \mathrm{C}$. Posteriormente las muestras se lavaron durante 30 minutos con PBS, y se permeabilizaron en la solución de $0.1 \%$ Tritón X-100 en $0.1 \%$ citrato de sodio (solución de permeabilización) durante 2 minutos en hielo. A continuación, previo a los procedimientos de marcaje, los controles positivos se incubaron con la DNasa I recombinante $(3 \mathrm{U} / \mathrm{ml}$ en $50 \mathrm{mM}$ Tris- $\mathrm{HCl}, \mathrm{pH} 7.5$, $1 \mathrm{mg} / \mathrm{ml} \mathrm{BSA}$ ) durante 10 minutos para inducir la rotura de las hebras del DNA. Posteriormente, las células se lavaron con PBS y se añadió en las muestras problemas y en los controles positivos $50 \mu \mathrm{l} /$ pocillo de la mezcla de reacción TUNEL, que contenía la enzima desoxirribonucleotidil transferasa terminal y los nucleótidos fluoresceinados. Mientras que los controles negativos se incubaron con $50 \mu \mathrm{l}$ de la solución del kit denominada label solution que contenía solo la mezcla de nucleótidos dUTP. Las muestras se incubaron durante 60 minutos a $37^{\circ} \mathrm{C}$ en oscuridad. Finalmente se realizaron tres lavados con PBS y se llevó a cabo la tinción de los núcleos con Hoechst 33258 ( $0.5 \mu \mathrm{g} / \mathrm{ml}$ concentración final) (Sigma-Aldrich), durante 5-10 minutos y se lavaron con PBS. Los cubres se montaron sobre portaobjetos con medio de montaje, y se analizaron las muestras en el microscopio de fluorescencia (Leica DMI3000 B). Para el análisis se seleccionaron tres campos al azar y se cuantificaron 200-300 células por muestra, en tres experimentos independientes. La viabilidad celular se determinó contabilizando las células muertas y se normalizaron frente al número total de células. 
14. Análisis de proteínas

\subsection{Obtención de extractos proteicos}

Para la extracción de proteínas partimos de macrófagos peritoneales murinos sometidos a la estimulación establecida en el estudio. Estas células se lavaron dos veces con PBS y se centrifugaron. El pellet obtenido se resuspendió en $1 \mathrm{ml}$ de buffer RIPA (20 mM Tris-HCl pH 7.4, 150 mM NaCl, 1 mM EDTA, 0.1 ácido deoxicólico, 1 \% Nonidet P-40, $0.1 \%$ SDS) suplementado con $10 \mu \mathrm{l}$ del cocktail de inhibidores de proteasas (Sigma-Aldrich) y se incubó durante 30 minutos en hielo. Los lisados se centrifugaron a $10.000 \mathrm{~g}$ durante 10 minutos a $4^{\circ} \mathrm{C}$. Posteriormente se cuantificaron las proteínas en cada uno de los sobrenadantes mediante el método de Bradford (Bio-Rad).

Se cogieron alícuotas de $20 \mu \mathrm{g}$ de proteínas de cada muestra y se mezclaron con tampón de carga Laemmli (50 mM Tris- $\mathrm{HCl}$ pH=6.8; 2 \% SDS; $10 \%$ glicerol; $1 \%$ azul de bromofenol; $25 \mathrm{nM}$ ditiotreitol). Se utilizaron las proteínas para separarlas en un gel de poliacrilamida o se congelaron a $-80^{\circ} \mathrm{C}$ para su posterior uso.

\subsection{Electroforesis en gel de poliacrilamida (SDS-PAGE)}

Para la separación de las proteínas, las muestras se sometieron a electroforesis. Las proteínas fueron desnaturalizadas, se hirvieron a $95^{\circ} \mathrm{C}$ durante 5 minutos en presencia del tampón de carga Laemmli. Las muestras se cargaron en un gel de poliacrilamida (10 \%) (Tabla 10), y también se añadió el marcador de peso molecular (Fisher Scientific), de tal forma que se separaron en función de su tamaño por migración hacia el polo positivo.

La electroforesis se realizó utilizando el tampón Tris-Glicina (2.5 mM Tris, 19.2 $\mathrm{mM}$ de glicina, $0.01 \%$ de SDS, $\mathrm{pH}=8.3$ ), durante 15 minutos a $50 \mathrm{~V}$, seguido de aproximadamente 60 minutos a $150 \mathrm{~V}$, hasta que el frente alcanzó la parte inferior del gel. 
Tabla 10. Preparación de los geles de poliacrilamida, el gel separador y el gel concentrador. (TEMED, N,N,N 'N '-tetrametiletilenediamina)

\begin{tabular}{|c|c|c|c|}
\hline Reactivos (mL) & $\begin{array}{l}\text { Gel separador } \\
\text { (stacking) }\end{array}$ & Reactivos (mL) & $\begin{array}{l}\text { Gel concentrador } \\
\text { (running)(4\%) }\end{array}$ \\
\hline $\mathrm{dd}_{2} \mathrm{O}$ & $4,84 \mathrm{ml}$ & $\mathrm{ddH}_{2} \mathrm{O}$ & $4,5 \mathrm{ml}$ \\
\hline $\begin{array}{l}40 \% \text { Acrilamida } 1,5 \mathrm{M} \\
\text { Tris (pH 6,8) }\end{array}$ & $2,5 \mathrm{ml}$ & $\begin{array}{l}40 \% \text { Acrilamida } 1,5 \mathrm{M} \\
\text { Tris }(\mathrm{pH} 6,8)\end{array}$ & $0,6 \mathrm{ml}$ \\
\hline 1,5 M Tris $(\mathrm{pH} 8,8)$ & $2,5 \mathrm{ml}$ & 1,5 M Tris $(\mathrm{pH} 8,8)$ & - \\
\hline 1,5 M Tris $(\mathrm{pH} 6,8)$ & - & 1,5 M Tris $(\mathrm{pH} \mathrm{6,8)}$ & $0,8 \mathrm{ml}$ \\
\hline $20 \%$ SDS & $0,05 \mathrm{ml}$ & $20 \%$ SDS & $0,03 \mathrm{ml}$ \\
\hline $\begin{array}{l}10 \% \text { APS (persulfato } \\
\text { amónico ) }\end{array}$ & $0,1 \mathrm{ml}$ & $\begin{array}{l}10 \% \text { APS (persulfato } \\
\text { amónico ) }\end{array}$ & $0,06 \mathrm{ml}$ \\
\hline TEMED & $0,01 \mathrm{ml}$ & TEMED & $0,006 \mathrm{ml}$ \\
\hline
\end{tabular}

\subsection{Análisis mediante Western blot: transferencia e inmunodetección}

Finalizada la electroforesis los geles fueron utilizados para realizar un Western blot. Se realizó la transferencia de los geles SDS-poliacrilamida a membranas de PVDF (Polyvinylidene Fluoride) previamente tratadas con metanol y lavadas con agua. La transferencia se realizó durante 60 minutos a $110 \mathrm{~V}$ en el aparato semi-seco Trans-Blot SD Semi-Dry Transfer Cell (Bio-Rad) usando un tampón de transferencia 1X (Tris 25 mM, glicina $192 \mathrm{mM}$, metanol $10 \%$ ). Posteriormente, la membrana se bloqueó con una solución de bloqueo TTBS 1X (20 mM Tris base; $150 \mathrm{mM} \mathrm{NaCl} ; 0.1 \%$ Tween20; $\mathrm{pH}=7.6$ ) al $5 \%$ de leche en polvo y $5 \%$ de BSA durante 60 minutos a temperatura ambiente. Tras el bloqueo, se realizaron lavados con TTBS e incubamos la membrana en presencia del anticuerpo monoclonal de conejo anti-AMPK $\alpha$ (Cell Signaling, \#2532) diluido 1:1.000 en solución con 1\% de leche en polvo en TTBS 1X durante toda la noche a $4^{\circ} \mathrm{C}$ en agitación. El otro anticuerpo monoclonal de conejo que se utilizó fue anti-phospho-AMPK $\alpha$ Thr172 (Cell Signaling, \#2531) y la actina (Sigma-Aldrich) como control de carga.

Al día siguiente se realizaron tres lavados de 10 minutos cada uno con TTBS 1X, con el fin de eliminar completamente el anticuerpo primario no adherido específicamente a la membrana, y se incubó la membrana en presencia del anticuerpo secundario anti-conejo conjugado marcado con peroxidasa de rábano (Amersham) diluido 1:5.000 en TTBS 1X durante 60 minutos a temperatura ambiente en agitación. Tras la incubación con el anticuerpo secundario, se realizaron tres lavados de 10 minutos cada uno con TTBS 1X, para eliminar el anticuerpo secundario no adherido específicamente a la 
membrana. Por último, se realizó la detección de las proteínas mediante quimioluminiscencia. Para ello se utilizó el kit de revelado Pierce ECL Western Blotting Substrate (Thermo Scientific), empleando el líquido de revelado. Se incubó a temperatura ambiente en agitación durante 1 minuto, se quitaron los restos del reactivo y se reveló la membrana. La película fotográfica y la membrana fueron enfrentadas a diferentes tiempos hasta encontrar aquel en el que se apreciaron mejor las proteínas en el estudio. Las películas fotográficas se revelaron con un equipo Curix-60 (AGFA).

La intensidad de las bandas se determinó mediante análisis densitométricos utilizando el software ImageJ.

\section{Análisis estadístico}

Los datos se expresaron como medias \pm error estándar de la media (SEM). Para el análisis estadístico se usó la prueba t de Student pareada (paired) y no pareada (unpaired) para la comparación de dos grupos, de al menos tres experimentos independientes. En experimentos con comparaciones múltiples, se utilizó la prueba de ANOVA con Bonferroni.

Se consideraron diferencias estadísticamente significativas cuando $\left.p<0.05 \quad{ }^{*}\right)$, $p<0.01\left(^{* *}\right)$ y cuando $\left.p<0.001{ }^{* * *}\right)$.

Los gráficos se realizaron utilizando el software GraphPad Prism versión 5, Adobe Photoshop 6.0 y Adobe Illustrator CS3. 


RESULTADOS 



\section{RESULTADOS}

El trabajo de esta tesis representa el análisis del papel de la proteína mitocondrial FASTK en el sistema inmunitario innato, en particular en la regulación de la fagocitosis no opsónica y los mecanismos que subyacen al fenotipo estudiado. La generación de los ratones deficientes en la proteína FASTK en el laboratorio nos ha permitido realizar el estudio de investigación en el que se desarrolla parte de esta tesis doctoral.

\section{Papel del complejo I en la capacidad fagocítica de los macrófagos} peritoneales murinos

Se ha descrito que la deficiencia de FASTK tanto en la línea celular 143B como en diferentes tejidos de ratón, como músculo esquéletico y cardíaco, resulta en la disminución de la actividad del complejo I del $50 \%$, demostrando que mitoFASTK es esencial para la biogénesis del mRNA ND6 (Jourdain et al., 2015). Además, los estudios previos realizados en nuestro laboratorio muestran una disminución del $41.1 \%$ en la actividad del complejo I de la cadena respiratoria mitocondrial en los macrófagos murinos peritoneales deficientes en la proteína FASTK (KO), mientras que las actividades de los otros complejos no se muestran alteradas. También sabemos que en los macrófagos murinos deficientes en la proteína FASTK hay un aumento de la fagocitosis no opsónica de bacterias.

Teniendo en cuenta estos antecedentes, nos planteamos estudiar si la disminución de la actividad del complejo I es responsable de la fagocitosis no opsónica. Para ello se emplea la inhibición química usando rotenona, flavonoide de origen vegetal que ha sido tradicionalmente empleado como pesticida, y que es un inhibidor específico del complejo I mitocondrial (NADH deshidrogenasa).

\subsection{Efecto de la rotenona en la viabilidad celular}

En primer lugar, en el laboratorio se ha determinado la concentración de rotenona que se requiere para una inhibición del $50 \%$ (IC50, inhibitory concentration 50) en la actividad del complejo I en los macrófagos peritoneales murinos, que resultó ser de $30 \mathrm{nM}$. Este resultado concuerda con los datos descritos en la literatura (Emmrich et al., 2013; Zhou et al., 2012; Chang et al., 2011) que utilizan dosis similares. Además, esta inhibición del 50 \% es similar a la observada en la actividad del Cl mitocondrial en los macrófagos peritoneales murinos deficientes en FASTK, como se ha descrito anteriormente.

Inicialmente planteamos realizar ensayos de viabilidad celular en los macrófagos peritoneales de tipo salvaje (WT) en presencia de rotenona, antes de llevar a cabo los ensayos de fagocitosis. Para ello, las células fueron expuestas a rotenona (30 nM) 
durante 24 horas, y se evaluó la viabilidad celular mediante la técnica de exclusión del colorante azul de tripán y la apoptosis con ensayos de TUNEL. La técnica TUNEL marca los extremos 3 'OH que quedan libres durante la fragmentación del DNA nuclear con nucleótidos dUTP fluoresceinados por medio de la enzima desoxirribonucleotidil transferasa terminal, de manera que es posible detectar in situ por técnicas de microscopia de fluorescencia en qué células están teniendo lugar los procesos de muerte.

Como se observa en la figura 19A-B, los resultados obtenidos mediante el ensayo de TUNEL, mostraron que la rotenona a $30 \mathrm{nM}$ no tenía un efecto en la viabilidad celular ni en la fragmentación del DNA nuclear en las células después de 24 horas de tratamiento, mientras que en las células sometidas a radiación ultravioleta $(100 \mathrm{~mJ}$, control positivo) sí que se observó una fragmentación del DNA (Figura 19A).

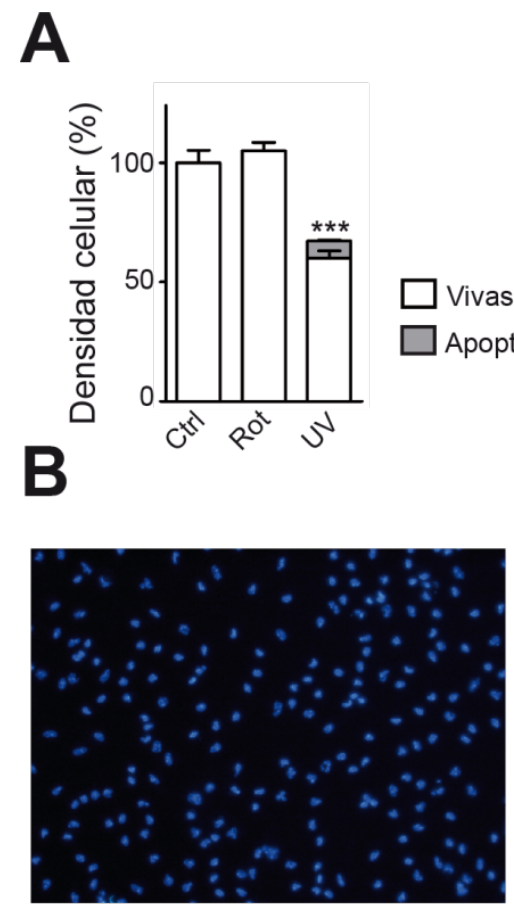

Control

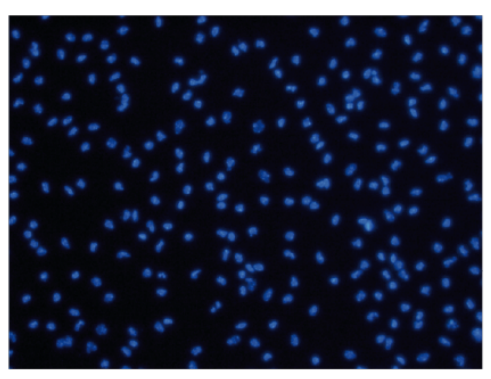

Rotenona

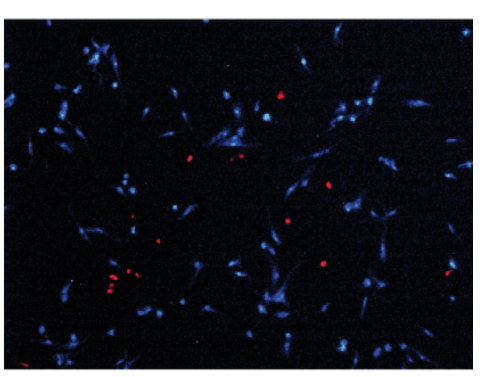

UV

Figura 19. Evaluación de la toxicidad del inhibidor específico del complejo I mitocondrial, la rotenona, en macrófagos peritoneales murinos. (A) La viabilidad y la apoptosis en macrófagos peritoneales murinos tratados con rotenona (30 nM) durante 24 horas. La viabilidad celular se determinó mediante tinción por exclusión con azul de tripán al $0.2 \%$ en tampón fosfato (PBS) y contaje con la cámara de Neubauer. Las células apoptóticas se detectaron con el ensayo de TUNEL. Los núcleos se tiñeron con Hoeschst 33342. Se representan los datos normalizados al control no tratado, de tres experimentos independientes $(n=3)$ como medias \pm error estándar. Test $t$ de student. (B) Imágenes representativas del ensayo de muerte celular mediante TUNEL (rojo) y Hoechst (azul) en macrófagos WT (control), células WT tratadas con rotenona y células sometidas a UV (control positivo) (aumento 20x). ${ }^{* \star *} p<0.001$ 


\subsection{Efecto de la rotenona en la fagocitosis no opsónica}

Una vez hubimos comprobado que la rotenona no afecta a la viabilidad celular, se llevaron a cabo los ensayos de fagocitosis en presencia de esta droga para determinar si la inhibición farmacológica del complejo I mitocondrial regula la capacidad fagocítica de los macrófagos. Se emplearon los macrófagos murinos peritoneales de tipo salvaje (WT), en presencia de las bacterias no opsonizadas E.coli y S.aureus, inactivadas con calor y marcadas con FITC, en una relación de 50:1 bacterias por célula durante una hora. Después de la incubación y tras varios lavados con PBS, las células se incubaron con azul de tripán con el fin de eliminar la señal fluorescente (quenching) de las bacterias extracelulares. Posteriormente, las células se lavaron con PBS y se fijaron añadiendo paraformaldehído a una concentración final del $4 \%$. Las células se lavaron de nuevo con PBS y los cubres se montaron sobre portaobjetos con medio de montaje. La fagocitosis se midió por microscopia de fluorescencia, mediante el índice fagocítico (IF), que se calcula multiplicando el porcentaje de macrófagos que habían fagocitado por la media de bacterias fagocitadas por macrófago. Como se muestra en la figura 20, el IF frente a E.coli está aumentado de forma significativa en los macrófagos tratados con rotenona (148.4 $\pm 4 \%$ ) respecto a los controles de tipo salvaje (WT) $(100 \pm 1.95 \%, p=0.002)$. De forma similar, el IF frente a S.aureus está aumentado en los macrófagos WT tratados con rotenona (123.4 $\pm 3.5 \%$ ) en comparación con los controles WT (103.1 $\pm 7.5 \%, p=0.035)$, aunque en este caso el aumento observado en la fagocitosis es menos significativo respecto al IF frente a la bacteria E.coli (Figura 20 y 21).

Estos resultados se compararon con el índice fagocítico de los macrófagos expuestos a partículas inertes de látex (beads) y a zymosán. El IF para las partículas inertes de látex marcadas con fluoresceína (beads, $2.0 \mu \mathrm{m}$ ), utilizadas como control de la ingesta, es similar en ambos grupos de macrófagos $(100 \pm 4.33 \%$ versus $100 \pm 3.21 \%, p=1)$. También se cuantificó la captación de partículas de zymosán, comparando el IF de los macrófagos WT y las células WT tratadas con rotenona. Como se puede observar en la figura 20 , no hay diferencias significativas en el IF entre los dos grupos de células (100 $\pm 2.35 \%$ versus $99.37 \pm 3.4 \%, p=0.88)$. En las gráficas representamos el valor del IF en \% respecto al grupo control que se considera el $100 \%$. 


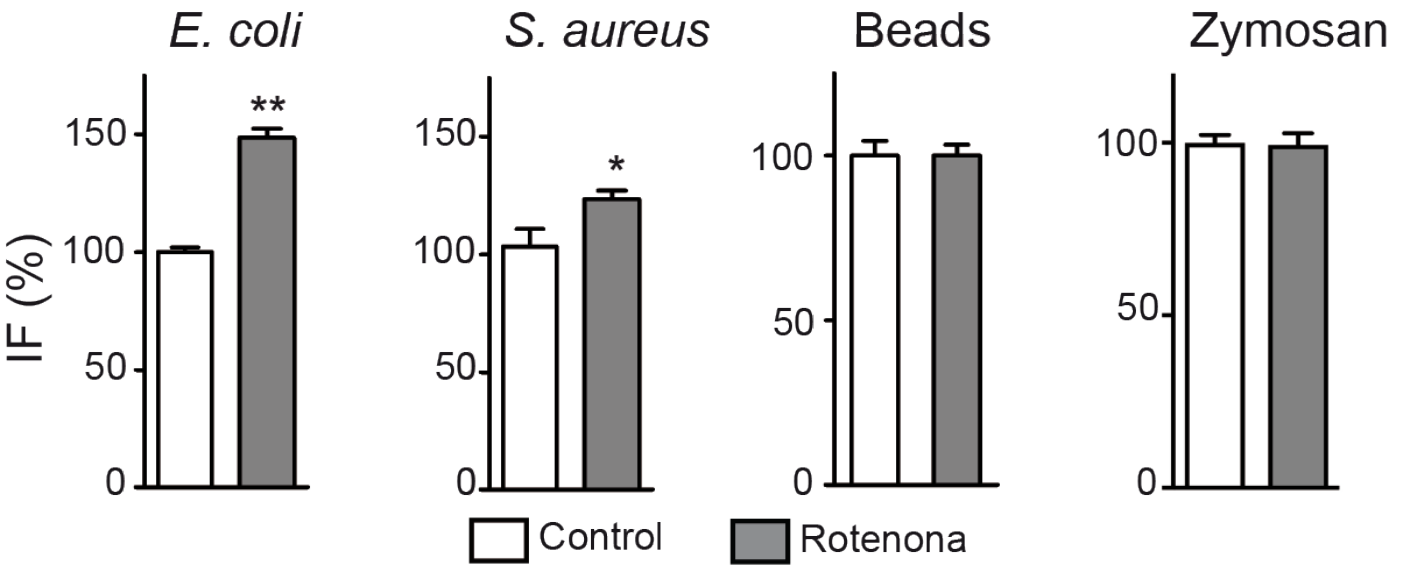

Figura 20. Índice fagocítico (IF) de E.coli, S.aureus, Beads (látex beads) y zymosán, en macrófagos peritoneales murinos tratados con el inhibidor específico del complejo I, rotenona. Los macrófagos salvajes (WT) tratados con el inhibidor específico del complejo I mitocondrial, la rotenona (30 nM) durante 24 horas, y no tratados con rotenona se incubaron con bacterias marcadas con fluoresceína (FITC), partículas inertes de látex (beads) y zymosán a una concentración aproximadamente de cincuenta bacterias o partículas por célula para provocar la fagocitosis en las células. Se representa en blanco las células WT, frente a las barras grises que representan las células tratadas con rotenona. Se representa la media \pm error estándar ( $n>7$ experimentos independientes). ${ }^{*} p<0.05,{ }^{* *} p<0.01$ (test $t$ de Student).

Por lo tanto, los macrófagos tratados farmacológicamente con rotenona presentan un aumento del índice fagocítico para las bacterias no opsonizadas, mientras que el IF frente a las partículas de zymosán y a las partículas inertes de látex (beads) no opsonizadas no muestran cambios en los macrófagos tratados con rotenona. Estos resultados se correlacionan con los obtenidos en los macrófagos deficientes en la proteína FASTK (estudio previo realizado en nuestro laboratorio). Los experimentos también se han llevado a cabo con otras dosis diferentes de rotenona, 10 y 100 nM (no se muestran los datos), obteniendo resultados muy similares a los macrófagos inhibidos con la dosis de rotenona ( $30 \mathrm{nM}$ ) empleada en el estudio.

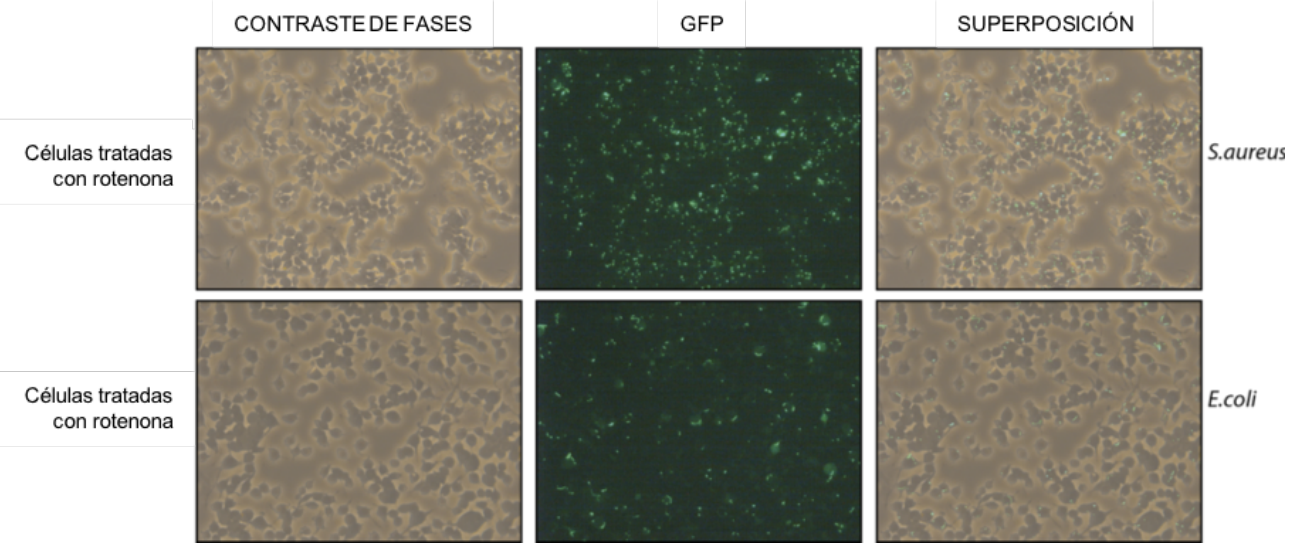

Figura 21. Imagen representativa de microscopia de la fagocitosis en macrófagos tratados con rotenona. En la parte superior de la figura se muestra la fagocitosis de la bacteria S.aureus marcada con FITC, mientras que en el panel inferior se representa la bacteria E.coli marcada con FITC. Las imágenes se presentan con un aumento de 20x. 


\subsection{Efecto de la rotenona en los macrófagos sobre la actividad bactericida}

A la vista de los hallazgos experimentales previos, se determinó la actividad bactericida mediante el ensayo de protección con gentamicina de los macrófagos WT tratados con rotenona. Durante este ensayo se emplearon bacterias vivas con el objetivo de estudiar la supervivencia bacteriana dentro del macrófago. Así pues, antes de comenzar con los ensayos de protección con gentamicina fue importante validar si la rotenona tiene un efecto en el crecimiento de las bacterias. Para ello se calculó la velocidad media de crecimiento (k) (Prescott et al., 2008) de los microorganismos empleados durante el estudio, en presencia y ausencia del inhibidor. Desde el punto de vista microbiológico un organismo muere cuando pierde la capacidad de dividirse, y no puede formar una colonia sobre un medio de cultivo. La velocidad media de crecimiento para E.coli es k=0.35 \pm 0.009 generación/hora en presencia de rotenona y $\mathrm{k}=0.37 \pm 0.001$ generación/hora en ausencia de rotenona (control) en medio de cultivo. La velocidad media de crecimiento para $S$.aureus es $k=0.45$ generación/hora en presencia de rotenona y $\mathrm{k}=0.45 \pm 0.0006$ generación/hora en ausencia de rotenona. Como se observa en la figura 22, pudimos comprobar que no hay diferencias significativas en la velocidad de crecimiento en presencia de rotenona en comparación con el control para los dos tipos de bacterias $(p=0.9358$ para E.coli y $p=0.9632$ para S.aureus), es decir, la rotenona no tiene un efecto en el crecimiento bacteriano.

A

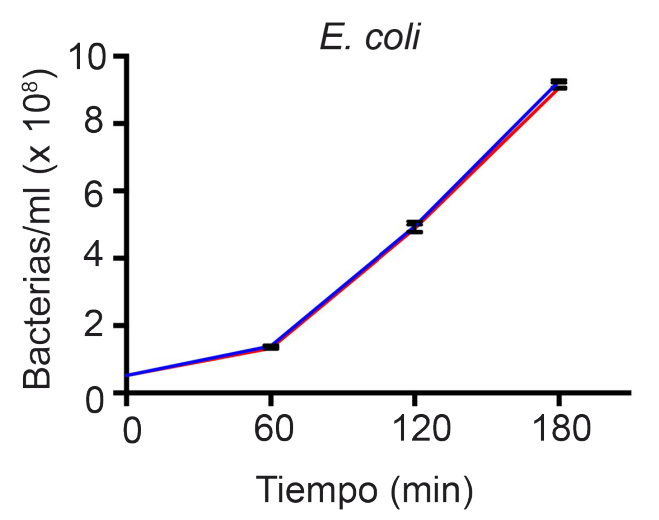

B

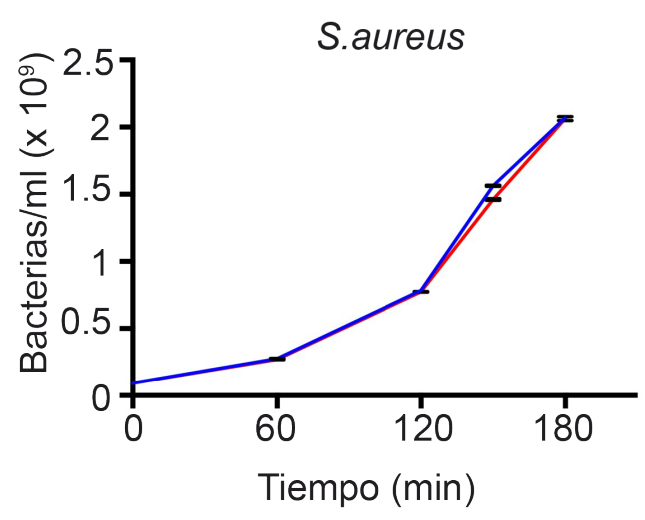

- Rotenona - Control

Figura 22. Velocidad de crecimiento de las bacterias en presencia del inhibidor. A. Velocidad de crecimiento de la bacteria Gram negativa en presencia y ausencia de la rotenona. B. Velocidad de crecimiento de la bacteria Gram positiva en presencia y ausencia de la rotenona. Se representan los datos de tres experimentos independientes ( $n=3)$ (test $t$ de Student).

Una vez que comprobamos que la rotenona no afecta al crecimiento bacteriano, se realizaron los ensayos de la actividad bactericida. En primer lugar, las células se 
expusieron a bacterias durante 1 hora y tras este periodo de incubación el medio se reemplazó por medio que contenía gentamicina.

Como se muestra en la figura $\mathbf{2 3}$, el número de bacterias que sobreviven en el ensayo de protección con gentamicina es similar en los macrófagos tratados con rotenona y en los que no están tratados a las 6 y 24 horas tras la infección. A las 6 horas las diferencias no son estadísticamente significativos en las células WT (controles) respecto a las células tratadas con rotenona frente a E.coli (855 \pm 1.38 UFC/pocillo versus $1275 \pm 1.20$ UFC/pocillo, $p>0.05$ ) y frente a S.aureus (19175 \pm 11.07 UFC/pocillo versus $21550 \pm 30.50$ UFC/pocillo, $p>0.05)$, ni a las 24 horas en E.coli $(780 \pm 1.58$ UFC/pocillo versus $820 \pm 0.5$ UFC/pocillo, $p>0.05)$ y en S.aureus (14337 \pm 12.37 UFC/pocillo versus $15375 \pm 12.60$ UFC/pocillo, $p>0.05$ ).

Mientras que, a las 2 horas tras la infección, el número de bacterias E.coli y S.aureus que sobreviven en el ensayo de protección con gentamicina es estadísticamente significativo en las células tratadas con rotenona respecto a los controles WT para E.coli (4837 \pm 1.80 UFC/pocillo versus $2827 \pm 0.98$ UFC/pocillo, $\mathrm{p}<0.001)$ y para S.aureus (38487 \pm 25.56 UFC/pocillo versus $27725 \pm 19.94$ UFC/pocillo, $\mathrm{p}<0.01)$. Este resultado era esperado dado que el número de bacterias que se recuperan a las 2 horas en el ensayo de protección a la gentamicina se correlaciona con la capacidad fagocítica ya estudiada. Estos datos demuestran que la actividad bactericida no está alterada en los macrófagos tratados con rotenona.

$$
\text { E. coli }
$$

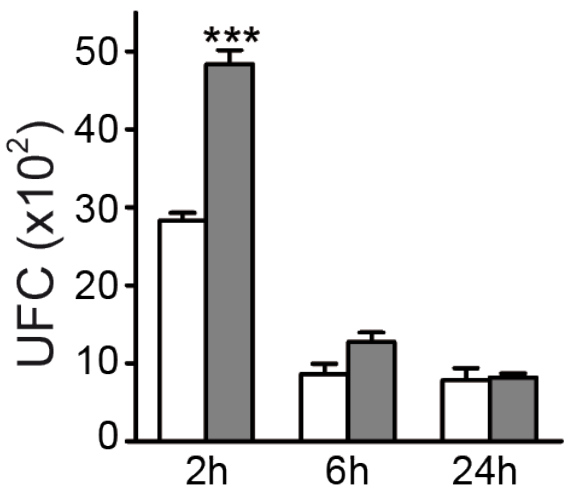

\section{S. aureus}

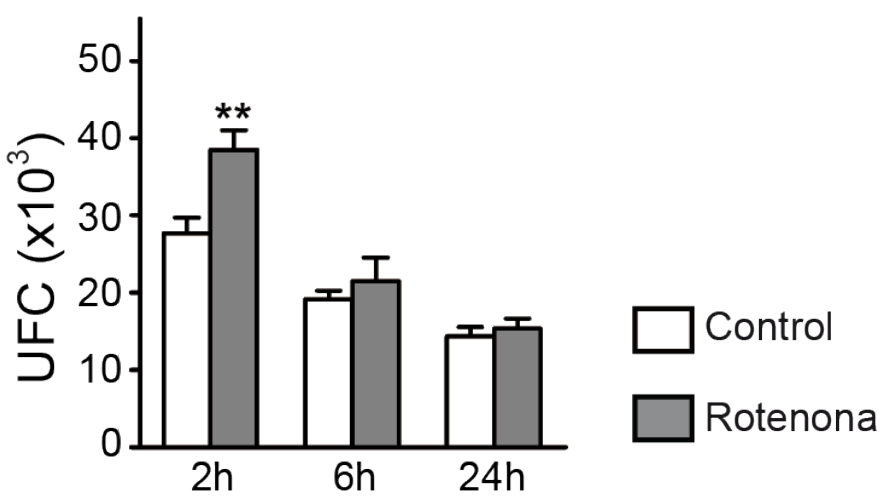

Figura 23. Capacidad fagocítica y actividad bactericida en los macrófagos peritoneales murinos de tipo salvaje y los tratados con rotenona en E.coli y S.aureus. Los macrófagos salvajes (WT) (en blanco) y macrófagos tratados con el inhibidor específico del complejo I mitocondrial, la rotenona (30 nM) (en gris) durante 2, 6 y 24 horas, se incubaron con bacterias a una concentración aproximadamente de diez bacterias por célula para provocar la fagocitosis en las células. La actividad bactericida se determinó por el ensayo de protección con gentamicina. Se muestran los números de unidades formadoras de colonias por pocillo (UFC/pocillo) en E.coli $\left(\times 10^{2}\right)$ y en S. aureus $\left(\times 10^{3}\right)$ obtenidos a las 2,6 y 24 horas después de la infección. Se muestra la media \pm error estándar ( $n>7$ experimentos independientes). ${ }^{* *} p<0.01,{ }^{* * *} p<0.001$, (ANOVA two way. Post-test Bonferroni). 
En paralelo a estos experimentos descritos y teniendo en cuenta que los radicales de oxígeno son importantes en la actividad bactericida (muerte bacteriana o killing), también se estudió la producción de radicales reactivos de oxígeno, como el radical superóxido $\mathrm{O}_{2}^{-}$y el oxígeno singlete, producidos principalmente por las enzimas unidas al fagosoma como la NADPH oxidasa. Para ello, se determinaron mediante el ensayo de quimioluminiscencia con luminol. El luminol es una sustancia permeable a las células que detecta los radicales intracelulares y extracelulares, especialmente el radical superóxido, el peróxido de hidrógeno, y el radical hidroxilo (Mahfouz et al., 2009). La presencia de un oxidante, en este caso los iones de oxígeno y los peróxidos que se generan durante la explosión oxidativa, permite que el luminol se oxide. Esta reacción se puede catalizar mediante la adición de la peroxidasa de rábano picante (HRP, horseradish peroxidase), y el luminol experimenta un cambio de conformación que a su vez conduce a la emisión de luz (Brungs et al., 2015). Los macrófagos WT, FASTK KO, y WT tratados con rotenona (30 nM), se expusieron a las bacterias E.coli, S.aureus y partículas de zymosán, en presencia del luminol y la HRP. La señal de luminiscencia se cuantificó cada cinco minutos en el luminómetro (Appliskan, Thermo Fisher Scientific).

El análisis que se llevó a cabo confirmó que los macrófagos WT, los macrófagos deficientes de FASTK (KO), y los macrófagos WT tratados con rotenona no muestran diferencias significativas en los niveles de ROS en el ensayo del luminol (Figura 24). Estos datos se correlacionan con los datos anteriores obtenidos en el ensayo de protección con gentamicina a las 6 horas y 24 horas. Estos resultados demuestran que la producción de ROS intracelulares en las células estimuladas con bacterias no está alterada en las tres situaciones evaluadas en el ensayo. 
A

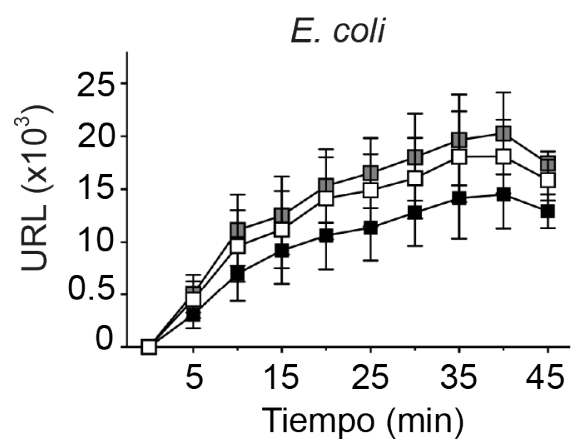

B

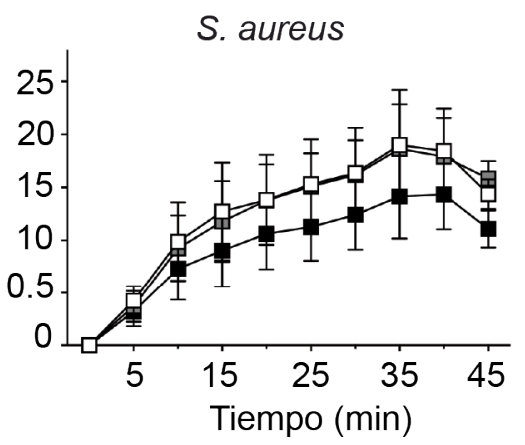

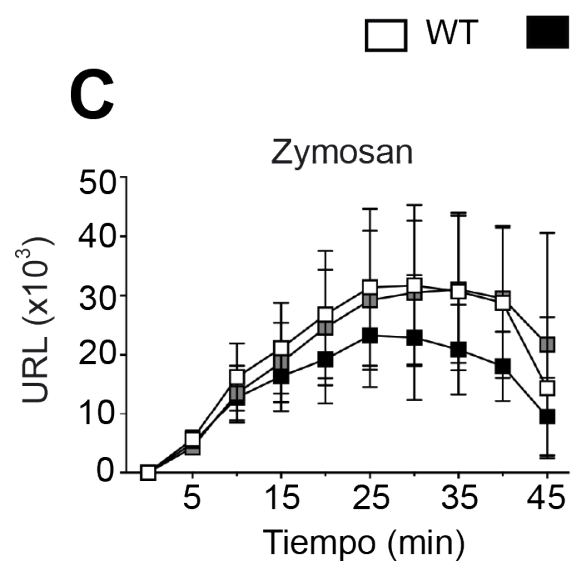

Figura 24. Producción de especies reactivas de oxígeno (ROS) en el ensayo de quimioluminiscencia basado en luminol. Producción total de ROS intracelular en presencia de las bacterias indicadas y de zymosán durante 45 minutos. Se analizaron por quimioluminiscencia con el ensayo de luminol en presencia de horseradish peroxidase (HRP) como se describe en la sección de Material y Métodos. Los datos se expresan en unidades relativas de luz (URL)/min ( $\times 10^{3}$ células). Se muestran la media \pm SEM ( $n>6$ experimentos independientes), $p>0.99$ (Two way ANOVA).

En conjunto, los resultados obtenidos indican que la capacidad intracelular de eliminar bacterias es independiente del complejo I mitocondrial, debido a que la actividad bactericida está inalterada en los macrófagos peritoneales murinos WT tratados con rotenona y las células deficientes en FASTK (KO) en comparación con el control (WT). Precisamente estos hallazgos concuerdan con el hecho previamente descrito en el laboratorio, mediante el ensayo de protección a la gentamicina en los macrófagos FASTK KO, de que la capacidad intracelular para eliminar bacterias era independiente de FASTK. 


\section{Análisis de la función del complejo I en la fagocitosis no opsónica en la línea celular RAW 264.7}

Una vez se estudió la inhibición química en los macrófagos peritoneales murinos, se llevó a cabo la inhibición genética de las subunidades del complejo I: NDUFS3 y NDUFS4, con el fin de estudiar el papel del complejo I en la regulación de la fagocitosis no opsónica. Para realizar el silenciamiento de cada una de las subunidades indicadas se ha utilizado la línea celular de macrófagos murinos RAW 264.7, establecida a partir de un tumor inducido por el virus de la leucemia murina de Abelson.

En el estudio de Vogel et al., se ha demostrado que NDUFS3 es una subunidad catalítica que tiene un papel vital en el ensamblaje correcto del complejo I (Vogel et al., 2007), pues codifica uno de los componentes de la proteína hierro-azufre de este complejo. Mientras que la subunidad NDUFS4 no está directamente involucrada en el transporte de electrones, sino que está implicada en la estabilidad del complejo I (Kruse et al., 2008; Kahlhöfer et al., 2017). Las mutaciones en estos dos genes están asociadas con el síndrome de Leigh que resulta de la deficiencia del complejo I mitocondrial.

En todos los experimentos de la fagocitosis no opsónica se han empleado como controles positivos para valorar el modelo, el silenciamiento de la proteína FASTK y la inhibición química con rotenona en esta línea celular. Debido a las siguientes evidencias halladas recientemente en nuestro laboratorio se silenció FASTK en la línea celular RAW 264.7 para emplearlo como control positivo: (i) la ausencia de la proteína mitocondrial FASTK en los macrófagos peritoneales murinos produce un aumento en la fagocitosis no opsónica de bacterias, y (ii) se ha descrito en estos macrófagos una disminución del $41.1 \%$ en la actividad del $\mathrm{Cl}$.

\subsection{Diseño, síntesis de los oligonucleótidos y clonación de los shRNA en el vector pGreenPuro}

Para la generación de la línea celular RAW 264.7 deficiente para NDUFS3, NDUFS4 y para FASTK (control positivo) se silenciaron estas subunidades utilizando vectores lentivirales que codificaban para los constructos shRNA. Las secuencias completas de cada uno de los genes a silenciar se obtuvieron de la base de datos de secuencias proporcionados por NCBI (National Center for Biotechnology Information) (RefSeq). Una vez identificadas las secuencias, se diseñaron los oligonucleótidos (entre 3 a 5 secuencias diana) de 19 pares de bases (19-mer) para cada gen de interés. Para ello se ha utilizado el programa online (http://cancan.cshl.edu/RNAi central/RNAi.cgi?type=shRNA) del laboratorio de Gregory Hannon (Hannon Lab), recomendado por el Manual del vector pGreenPuro que se ha empleado para la clonación. Se han seguido los criterios generales para el diseño de 
los oligonucleótidos que indicaba el Manual que incluyen la adición de una secuencia loop (de bucle) entre la cadena sentido y antisentido; una secuencia de terminación TTTTT para la RNA polimerasa III, y secuencias para los sitios de restricción BamHI y EcoRI flanqueando los oligonucleótidos para la clonación direccional de los mismos en el vector pGreenPuro.

Se llevó a cabo la clonación de los insertos shRNA en el vector pGreenPuro. En primer lugar, se linearizó el vector pGreenPuro por digestión con las enzimas de restricción BamHI y EcoRI, situadas cerca del promotor $\mathrm{H} 1$, mediante una digestión durante dos horas, y se purificó el plásmido.

En segundo lugar, los oligonucleótidos diseñados se anillaron y se realizó la ligación con el vector linearizado. Posteriormente, se transformó el producto de la ligación para cada shRNA en bacterias E.coli competentes siguiendo el protocolo descrito en Material y Métodos. Las colonias que se obtuvieron del producto de la ligación eran resistentes a ampicilina $(50 \mu \mathrm{g} / \mathrm{ml})$, y se utilizaron para la extracción del DNA plasmídico mediante mini y midiprep. Se comprobó su pureza y se analizaron mediante PCR con los primers indicados en Material y Métodos (Tabla 7) para verificar la correcta ligación de los insertos en el vector. El tamaño esperado de los clones sin el inserto fue un producto de $105 \mathrm{bp}$, mientras que el de los clones amplificados con el inserto shRNA fue entre 150-170 bp (Figura 25). Por último, se confirmaron si los plásmidos obtenidos tenían el inserto correctamente clonado mediante secuenciación (Anexo I) de los productos positivos de PCR con los primers indicados en la sección de Material y Métodos (Tabla 7).

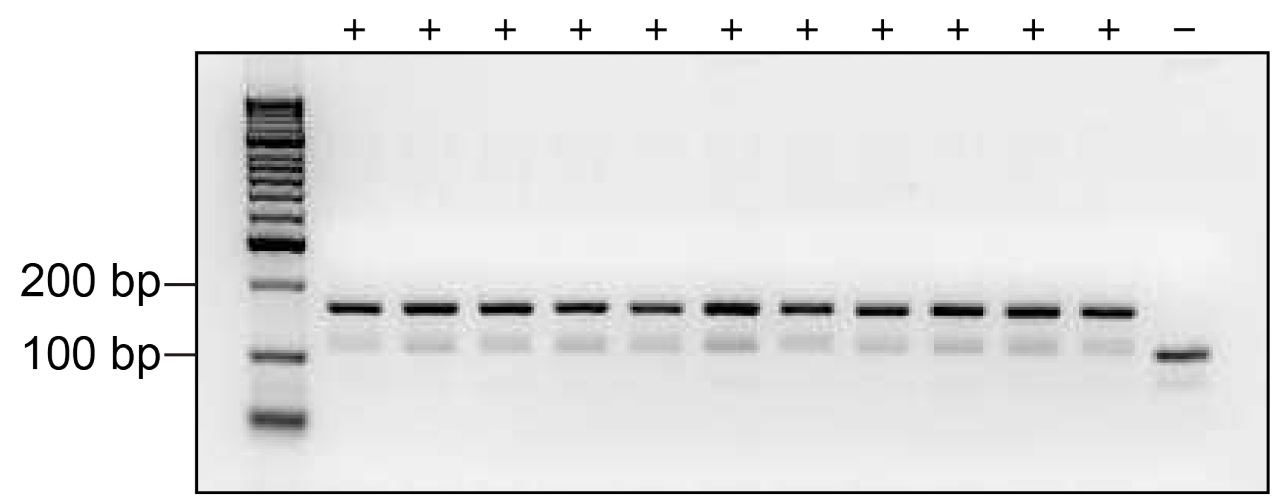

Figura 25. Análisis por PCR utilizando los primers del screening para shRNAs en el vector pGreenPuro. Los clones sin el inserto dan un producto de $105 \mathrm{bp}$. El tamaño esperado para los clones amplificados con un inserto es de 150-170 bp. 


\subsection{Producción de partículas virales shRNA y transducción en células}

Una vez que se realizó la clonación, se procedió a la transfección en las células empaquetadoras 293FT utilizando TransIT X2. Para ello se utilizaron dos plásmidos comerciales (psPAX2 y pMD2.G) y cada uno de los plásmidos "silenciadores" (NDUFS3, NDUFS4, ó FASTK). El plásmido psPAX2 posee los genes que codifican para las proteínas Gag, Pol, que forman las proteínas de la envuelta, Tat que es una proteína que regula el aumento de la eficiencia de la transcripción viral y Rev que es una proteína que permite la exportación desde el núcleo al citoplasma de los fragmentos de mRNA que contienen el elemento RRE para producir el genoma viral. El plásmido pMD2.G contiene el gen que codifica para la glicoproteína del virus de estomatitis vesicular y es una proteína involucrada en la formación de la envoltura viral. Tras la transfección, a las 48 horas se obtuvieron los lentivirus, como se explica en la sección de Material y Métodos, por ultracentrifugación del sobrenadante del cultivo celular. Para el cálculo del título viral se utilizó qRT-PCR del cDNA obtenido a partir del vector lentiviral, y fue de entre $10^{6}-10^{8}$ partículas virales $/ \mathrm{ml}$.

En los experimentos de transducción se sembraron 100.000 células RAW 264.7 en una placa de 24 pocillos y se realizó la transducción en las células un día después. Los lentivirus se dejaron incubar durante 12 horas, tras este tiempo se retiró el medio y se sustituyó por medio completo en presencia de puromicina como antibiótico de selección. Dado que la resistencia a la puromicina puede variar dependiendo del tipo celular, se realizaron curvas de dosis-respuesta a diferentes concentraciones de puromicina $(0.25$ a $10 \mu \mathrm{g} / \mathrm{ml})$ en una placa de 24 pocillos. De esta forma se determinó la concentración más baja de antibiótico que es capaz de matar al $100 \%$ de las células no transducidas, que resultó ser de $7 \mu \mathrm{g} / \mathrm{ml}$. De esta forma las células infectadas que contenían el casete de resistencia a puromicina se seleccionan mediante resistencia al antibiótico.

El vector pGreenPuro a parte de contener un gen de resistencia a la puromicina para permitir la selección de las células diana que expresan shRNA, tiene un gen copGFP. El gen copGFP codifica para una proteína fluorescente verde derivada del plancton copépodo (Panalina sp.) que es similar a EGFP (enhanced green fluorescent protein), pero tiene un color más brillante. Este gen sirve como un indicador fluorescente para las células transducidas. Así pues, se monitorizaron las células infectadas por microscopía de fluorescencia a las 72 horas de la transducción, y se confirmó que expresaban copGFP (Figura 26). También se analizó la expresión de copGFP mediante citometría de flujo, obteniendo $90 \%$ de las células positivas para copGFP. Estos resultados confirman que las células estables se generaron correctamente. 
A

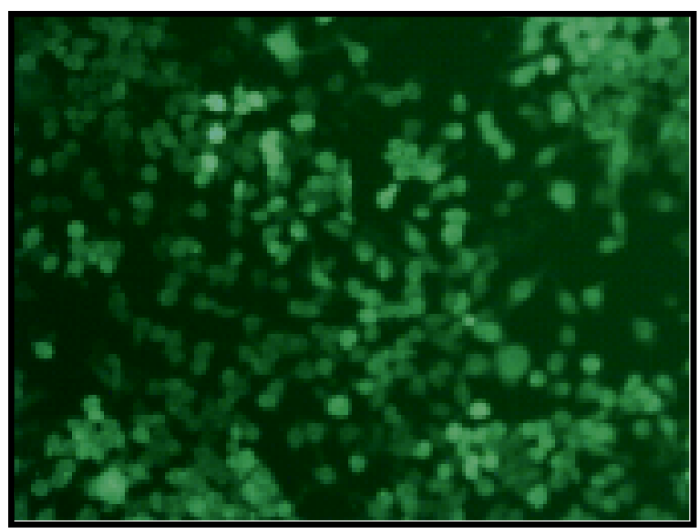

shNDUFS4
B

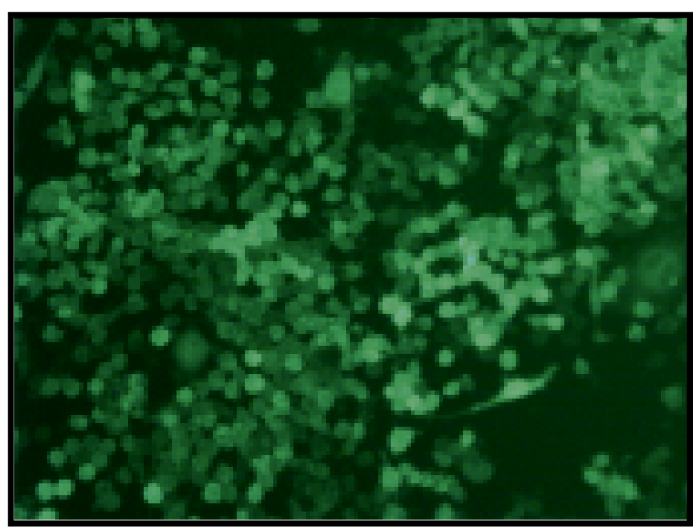

shNDUFS3

Figura 26. Imágenes de las células RAW 264.7 silenciadas en las subunidades del complejo I, NDUFS3 y NDUFS4 que expresan el gen copGFP.Se demuestra que han incorporado las partículas virales shRNA de NDUFS4 y NDUFS3. En la imagen de la derecha se representan las células silenciadas en NDUFS4, mientras que en la imagen de la izquierda se representan las células silenciadas en NDUFS3.

Las células se mantuvieron en placas de 24 pocillos hasta que los clones alcanzaron el $90 \%$ de la superficie del pocillo para ser analizados.

\subsection{Comprobación de la ausencia de NDUFS3, NDUFS4 y FASTK en la línea celular de macrófagos murinos RAW 264.7 mediante qRT-PCR}

Se analizó la ausencia de mRNA de NDUFS3, NDUFS4 y FASTK en las líneas celulares modificadas RAW 264.7, mediante qRT-PCR con los primers indicados en la sección de Material y Métodos (Tabla 8). El método de cuantificación utilizado fue $2^{-\Delta \Delta C t}$, para comparar los $\Delta \mathrm{Ct}$ de los genes testados y el gen normalizador ( $\beta$-actina) para cada muestra.

Mediante este experimento se observó una eficacia de silenciamiento del $73.5 \%$ en el mRNA de NDUFS3, del $66.6 \%$ en el mRNA de NDUFS 4 y del $57.7 \%$ en el mRNA de FASTK (Figura 27). Se comprobó la ausencia de la expresión relativa del mRNA normalizado a la expresión $\beta$-actina en NDUFS3 de $0.26 \pm 0.09(p=0.0002)$, en NDUFS4 de $0.33 \pm 0.14(p=0.0027)$ y en FASTK de $0.42 \pm 0.01(p<0.0001)$ respecto al control $(1 \pm 0.0008)$. 


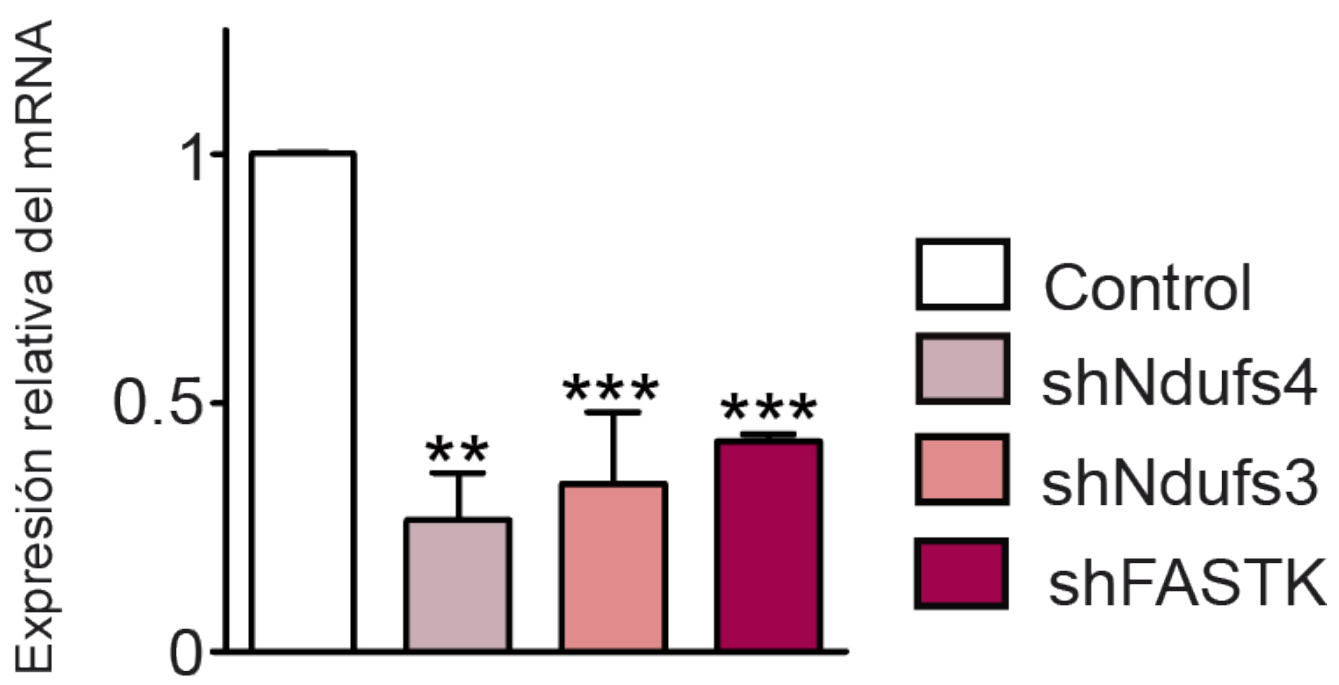

Figura 27. Gráfico en el que se muestra la cuantificación relativa del mRNA de los genes NDUFS4, NDUFS3 y FASTK, analizados mediante $q R T-P C R$ en la línea celular RAW 264.7 aplicando el método $2^{-\Delta \Delta C t}$. El control empleado fue el vector vacio (shpGreenPuro). El gen $\beta$-actina ha sido utilizado como normalizador. Análisis estadístico $t$ de student. Media \pm error estándar ( $n=3$ experimentos independientes). ${ }^{* *} p<0.01,{ }^{* * *} p<0.001$ (t de Student).

\subsection{Estudio de la fagocitosis no opsónica en los macrófagos murinos silenciados en NDUFS3, NDUFS4, FASTK, y las células inhibidas farmacológicamente con rotenona}

Generadas las herramientas de trabajo se procedieron a realizar los experimentos de fagocitosis propuestos en el estudio, para investigar de qué forma afecta el silenciamiento de estas subunidades NDUFS3 y NDUFS4 a la capacidad fagocítica de los macrófagos.

Para los experimentos de fagocitosis se sembraron 500.000 células por triplicado por condición en una placa de 24 pocillos. Se emplearon como control negativo las células RAW 264.7 y las células RAW 264.7 transducidas con el vector vacío (shpgreen). Se obtuvieron resultados muy similares en los dos controles y los datos que se representan en este estudio como control negativo son respecto a las células infectadas con el vector vacío (shpgreen).

En la línea celular RAW 264.7 se empleó la misma dosis de rotenona (30 nM) que se ha utilizado anteriormente con los macrófagos peritoneales murinos, dado que en el laboratorio se había determinado, por la curva dosis-respuesta, que una concentración de 30 nM inhibía un 50 \% la actividad del complejo I. Además, se evaluó la viabilidad de las células RAW 264.7 expuestas a rotenona (30 nM) del modo usual, mediante tinción por exclusión con azul de tripán al $0.2 \%$ en tampón fosfato (PBS) y 
contaje al microscopio con la cámara de Neubauer, demostrando que la rotenona no afecta la viabilidad celular en esta línea celular de macrófagos, como se confirmó previamente en los macrófagos peritoneales murinos.

Dado nuestro interés en estudiar la función del complejo I en la regulación de la fagocitosis no opsónica, se realizaron los ensayos de fagocitosis exponiendo los macrófagos RAW 264.7 silenciados para las subunidades NDUFS3, NDUFS4 y FASTK, y los macrófagos RAW 264.7 tratados con el inhibidor rotenona, a las bacterias E.coli y S.aureus no opsonizadas, inactivadas con calor y marcadas con TRITC (Figura 28), y a las partículas inertes de látex (beads) y de zymosán. CONTRASTE DE FASES
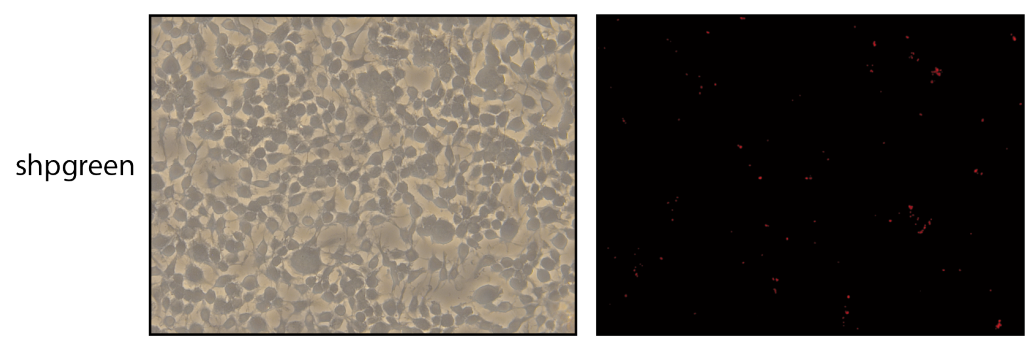
SUPERPOSICIÓN
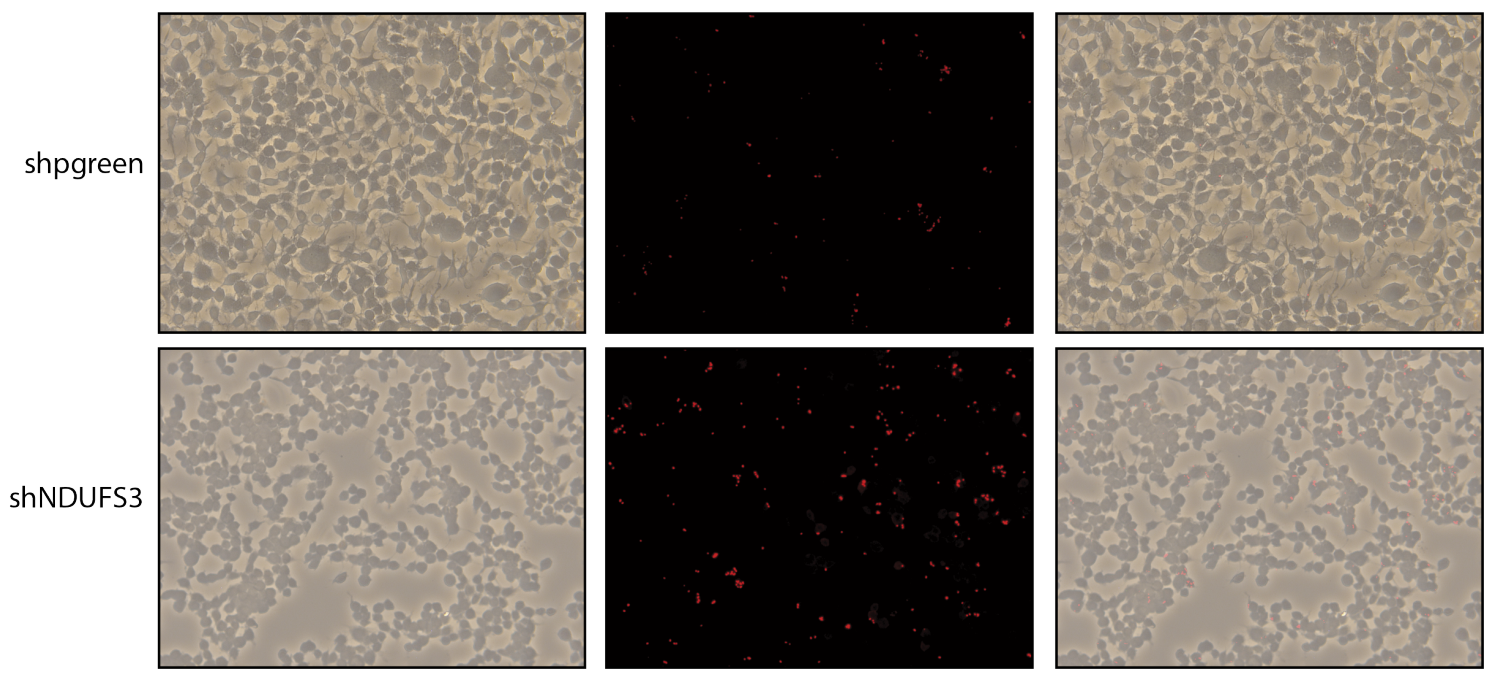

Figura 28. Imágenes representativas durante la fagocitosis bacteriana. En el panel superior se visualizan las células control shpgreen (el vector pGreenPuro vacío), mientras que en el panel inferior se representan las células shNDFUS3. Las bacterias que se representan son S. aureus-TRITC. Las imágenes se presentan con un aumento de 20x.

Las células se incubaron durante 1 hora y se cuantificó el índice fagocítico multiplicando el porcentaje de células que han fagocitado por la media de las bacterias fagocitadas por célula. Los resultados del índice fagocítico para cada cepa bacteriana se muestran en la figura 29. Se observa que hubo un aumento significativo en el índice fagocítico frente a la bacteria E.coli en los macrófagos shNDUFS3 respecto al control $(199.3 \pm 11.58 \%$ versus $100 \pm 4.65 \%, p=0.0013)$ y en los macrófagos shNDUFS4 en comparación con el control $(177.7 \% \pm 13.52$ versus $100 \% \pm 4.65, p=0.0056)$. De forma similar, el IF para S.aureus estaba incrementado en los macrófagos shNDUFS3 respecto al control $(148.4 \% \pm 9.05$ versus $100 \% \pm 3.03, p=0.0003)$ y en los macrófagos shNDUFS4 el IF también estaba aumentado en comparación con el control $(135.1 \% \pm 4.06$ versus $100 \% \pm 3.03, p=0.0003)$. 
En los controles positivos también se observó en el porcentaje de fagocitosis de ambas cepas bacterianas un aumento significativo. EI IF frente a E.coli en los macrófagos shFASTK respecto al control presentan diferencias significativas (190.1 \pm $5.168 \%$ versus $100 \pm 4.65 \%, p=0.0002$ ). Como se muestra en la Figura 29, también se observó un aumento en el IF frente a E.coli en los macrófagos tratados con rotenona (30 $\mathrm{nM}$ ) respecto al control (166.4 $\pm 7.9 \%$ versus $100 \pm 4.65 \%, p=0.002)$. El IF frente a la bacteria S.aureus resultó en un aumento en los macrófagos shFASTK respecto a las células control $(150.2 \pm 3.19 \%$ versus $100 \pm 3.03 \%$, p<0.0001). En la línea celular RAW 264.7 tratada con rotenona y expuesta a S. aureus también resultó en un aumento en el índice fagocítico $(128.2 \pm 0.40 \%$ versus $100 \pm 3.03 \%, p=0.0004)$, como esperábamos.

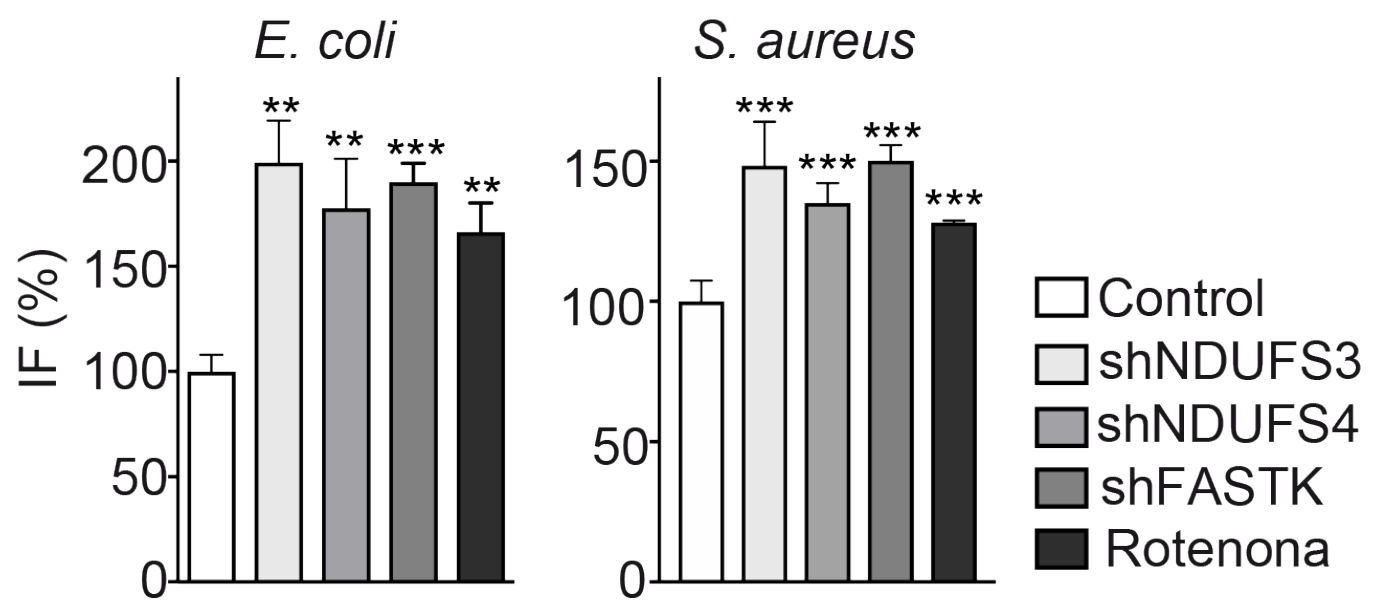

Figura 29. Índice fagocítico de E.coli y S.aureus en las células control (vector vacío), shNDUFS3 CDS, shNDUFS4 CDS, shFASTK CDS y macrófagos tratados con rotenona ( $30 \mathrm{nM}, 24$ horas). El IF de E.coli y S.aureus se representa como el porcentaje de macrófagos que han fagocitado por la media de bacterias fagocitadas por célula. La concentración de bacterias expuestas fue aproximadamente de cincuenta bacterias por macrófago (50:1). Los valores del índice fagocítico fueron normalizados frente al control, de manera que los valores medios de los controles negativos (vector vacío transfectado en la línea celular RAW 264.7) se fijaron en $100 \%$. Se representa la media \pm error estándar ( $n=3$ experimentos independientes). ${ }^{*} p<0.05,{ }^{* *} p<0.01,{ }^{* * *} p<0.001$. Análisis estadístico t de Student, unpaired t test, two-tailed.

El siguiente paso fue cuantificar la fagocitosis de partículas inertes látex y zymosán marcado con TRITC, en ausencia de suero fetal bovino, a través de la observación con el microscopio de fluorescencia. Las bolas o microesferas de látex (2.0 $\mu \mathrm{m}$ de diámetro) marcadas con fluoresceína se utilizaron como control de la ingesta de partículas inertes y también se utilizó el zymosán (3.0 $\mu \mathrm{m}$ de diámetro) sin opsonizar como partícula fagocitable. Se incubaron con las células durante 1 hora y se realizó la cuantificación de las partículas fagocitadas, como se ha detallado previamente.

Se demostró que la fagocitosis no opsónica de las partículas mencionadas era similar entre los macrófagos control y las células en las que se había silenciado 
NDUFS3, NDUFS4 y FASTK (shNDUFS3, shNDUFS4 y shFASTK, respectivamente) así como en las células inhibidas con rotenona. En la figura $\mathbf{3 0}$ se representa una comparación del IF de los macrófagos shNDUFS3 y shNDUFS4 frente a las partículas de látex y zymosán respecto a los macrófagos control. Esta comparación muestra que el índice fagocítico para las partículas inertes de látex (beads) era similar entre los macrófagos shNDUFS3 y control $(101.2 \pm 2.55 \%$ versus $100 \pm 5.13 \%, p>0.05)$, también se muestra que no había diferencias significativas entre los macrófagos shNDUFS4 y control ( $97.63 \pm 3.04 \%$ versus $100 \pm 5.13 \%$, p>0.05). Asimismo, tampoco había diferencias significativas en el índice fagocítico para zymosán entre los macrófagos shNDUFS3 y el control $(99.60 \pm 5.11 \%$ versus $100.0 \pm 2.98 \%, p>0.05) \mathrm{ni}$ en los macrófagos shNDUFS4 respecto al control (93.31 $\pm 3.72 \%$ versus $100.0 \pm 2.98 \%$, $p>0.05)$.

En los controles positivos se observaron resultados similares en el IF para las partículas inertes de látex en los macrófagos shFASTK respecto a los macrófagos control (99.87 $\pm 4.264 \%$ versus $100 \pm 5.13 \%, p>0.05)$. El IF para las partículas inertes látex (beads) era similar en las células control y las tratadas con rotenona (100 $\pm 5.13 \%$ versus $99.39 \pm 3.86 \%, p=0.929$ ). Tampoco hay diferencias significativas en los índices fagocíticos cuantificados para el zymosán entre los macrófagos shFASTK y las células control (109.2 $\pm 2.71 \%$ versus $100 \pm 2.98 \%, p>0.05)$. Asímismo, el IF de las células incubadas con rotenona y expuestas a zymosán no presentan diferencias significativas entre ambos grupos de macrófagos $(90.12 \pm 3.89 \%$ versus $100 \pm 2.98 \%, p=0.06)$ (Figura 30).

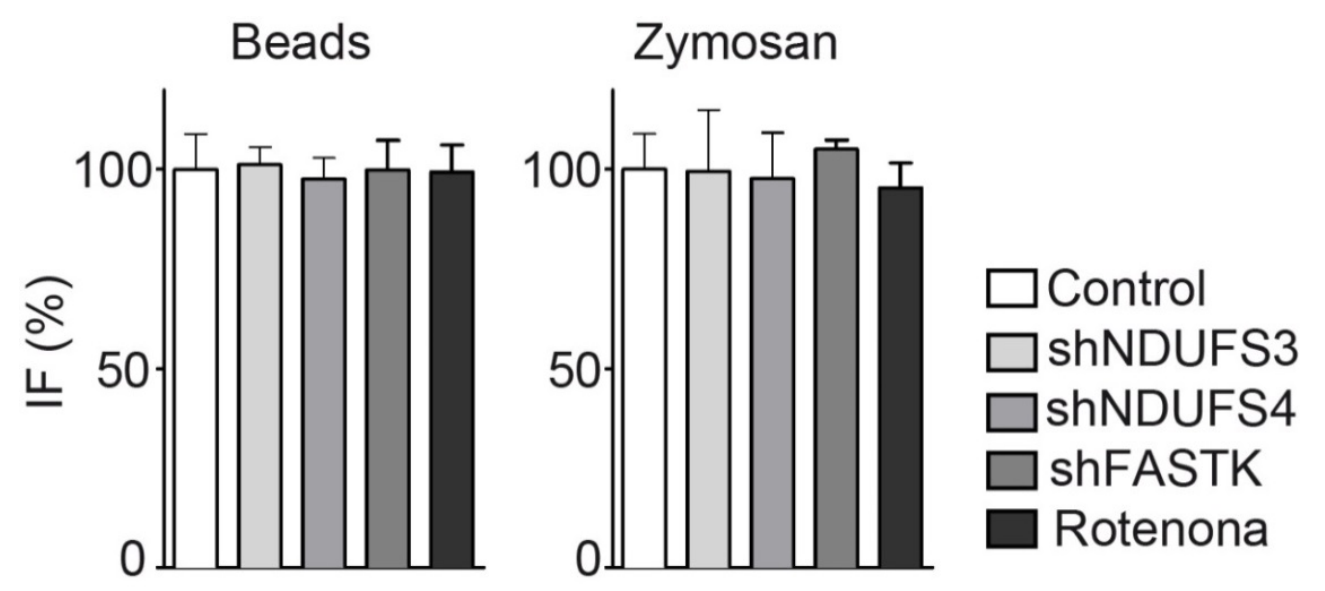

Figura 30. Índice fagocítico (IF) para las partículas de látex (beads) y zymosán, en las células control (vector vacío), shNDUFS3 CDS, shNDUFS4 CDS, shFASTK y macrófagos tratados con rotenona (30 nM, 24 horas). Los valores del índice fagocítico fueron normalizados frente al control. Se representa la media \pm error estándar ( $n=3$ experimentos independientes) (t de Student). 
Por otro lado, se llevaron a cabo los ensayos de protección con gentamicina a la hora post-infección, en presencia de bacterias E.coli y S.aureus vivas. En este ensayo las células se incubaron con bacterias en una relación 10:1 bacterias:macrófago durante una hora, y después se añadió la gentamicina al medio $(100 \mu \mathrm{g} / \mathrm{ml})$ durante una hora para eliminar las bacterias extracelulares adherentes. En los experimentos que se llevaron a cabo, el número de bacterias E.coli y S.aureus que sobreviven al ensayo fue más elevado en los macrófagos silenciados (shNDUFS3, shNDUFS4, shFASTK) y las células incubadas con rotenona en comparación con los macrófagos control (Figura 31). El número de colonias que se recuperaron de E.coli en los macrófagos shNDUFS3 en comparación con el control fue significativamente mayor (3510 \pm 3.2 UFC/pocillo versus $967 \pm 1.54$ UFC/pocillo, $p<0.0001)$ y de S.aureus (29560 \pm 17.74 UFC/pocillo versus $20000 \pm 23$ UFC/pocillo, $p=0.0053$ ). De forma similar, el número de las bacterias vivas que sobreviven muestra un aumento significativo en los macrófagos shNDUFS4 respecto al control: E.coli (3737 \pm 4.16 UFC/pocillo versus $967 \pm 1.54$ UFC/pocillo, p<0.0001) y S.aureus $(29750 \pm 17.08$ UFC/pocillo versus $20000 \pm 23$ UFC/pocillo, $\mathrm{p}=0.0043)$.

En los controles positivos del experimento, se demostró que el número de bacterias que sobreviven de E.coli fue superior en los macrófagos shFASTK en comparación con las células control (shpGreen) (3270 \pm 2.43 UFC/pocillo versus $967 \pm$ 1.54 UFC/pocillo, $p=0.0001$ ). El número de colonias de S.aureus fue superior en los macrófagos shFASTK respecto a los macrófagos control (33700 \pm 22.52 UFC/pocillo versus $20000 \pm 23$ UFC/pocillo, $p=0.0038$ ) (Figura 31). De forma similar, el número de E.coli y S.aureus que sobreviven al ensayo de protección con gentamicina es estadísticamente significativo en las células tratadas con rotenona respecto a los controles: con la bacteria E.coli (3696 \pm 2.74 UFC/pocillo versus $967 \pm 1.54$ UFC/pocillo, $\mathrm{p}<0.0001)$ y con S.aureus $(29800 \pm 18.96$ UFC/pocillo versus $20000 \pm 23$ UFC/pocillo, $\mathrm{p}=0.0054)$. Estos datos se correlacionan con los índices fagocíticos cuantificados previamente. 


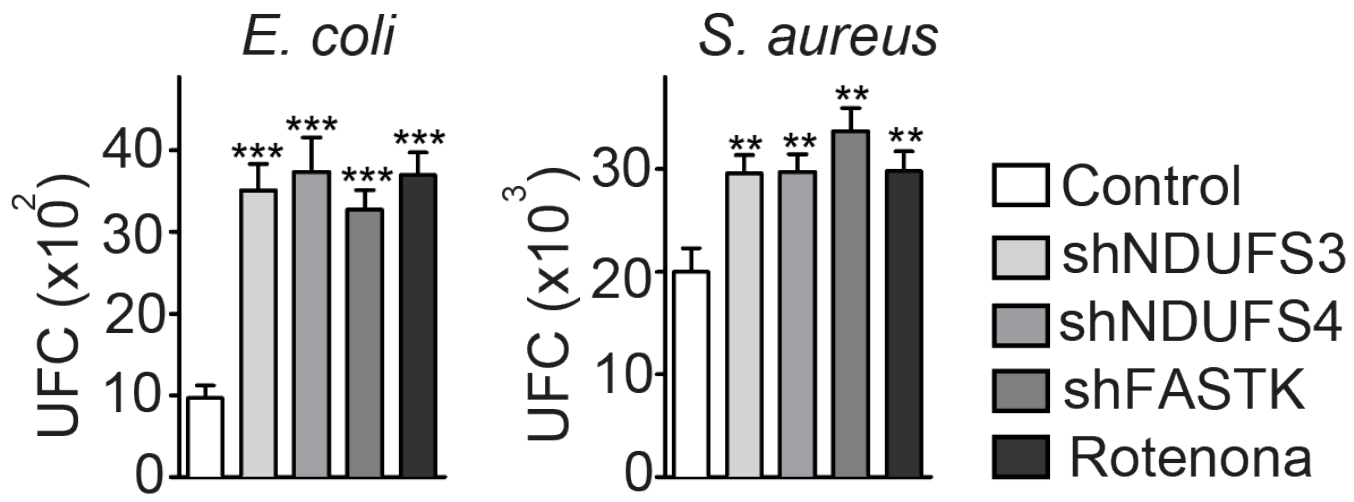

Figura 31. Capacidad de los macrófagos para fagocitar E.coli y S.aureus en los macrófagos deficientes en dos subunidades del complejo I (NDUFS3 y NDUFS4), macrófagos deficientes en FASTK y en los macrófagos tratados con rotenona (30 nM). La capacidad fagocítica se determinó con el ensayo de protección a la gentamicina. Se muestran los números de unidades formadoras de colonias por pocillo (UFC/pocillo) en E.coli y S.aureus $\left(\times 10^{2}\right)$ obtenidos a la hora después de la infección (post-infección). Los macrófagos se incubaron con bacterias a una concentración aproximadamente de diez bacterias por célula para provocar la fagocitosis en las células. Media \pm error estándar ( $n=4$ experimentos independientes). ${ }^{* *} p<0.01,{ }^{* * *} p<0.001$ (t de Student, Unpaired $t$ test, two-tailed).

En conjunto, estos resultados constatan que el silenciamiento de las dos subunidades del complejo I mitocondrial, NDUFS3 y NDUFS4, dan lugar al mismo fenotipo que los macrófagos RAW 264.7 tratados con el inhibidor rotenona y las células silenciadas en la proteína FASTK (que se han tomado como controles positivos de la investigación), y que los macrófagos murinos tratados con rotenona (resultado del apartado anterior), y que los macrófagos murinos deficientes en la proteína FASTK (KO) (resultado obtenido en estudios anteriores realizados en nuestro laboratorio mencionado anteriormente). Los datos indican que el defecto del complejo I aumenta la capacidad de fagocitar bacterias.

\section{Rescate del fenotipo fagocítico de las células RAW 264.7 en las que se ha}

silenciado FASTK mediante la reexpresión de la isoforma mitocondrial de FASTK

Como ya se ha explicado antes el $50 \%$ de la proteína FASTK se localiza en la mitocondria (mitoFASTK) mientras que el resto se distribuye entre el núcleo y el citosol (cytoFASTK). La isoforma mitocondrial de FASTK se sintetiza a través de un sitio alternativo de iniciación de la traducción (metionina 35) y carece de los primeros 34 aminoácidos presentes en el extremo $\mathrm{N}$-terminal de la proteína FASTK, mostrando una señal de localización mitocondrial (Jourdain et al., 2015).

Para conocer si la isoforma mitocondrial de FASTK es la responsable del fenotipo fagocítico que hemos observado en los resultados descritos anteriormente, se llevaron a cabo experimentos de rescate. Para ello, se generaron con lentivirus células 
RAW 264.7 que expresaban shRNA contra la región 5'UTR de FASTK. En primer lugar, se diseñaron tres oligonucleótidos diferentes (shUTR57, shUTR18-1, shUTR18-2) contra esta región de FASTK. Se llevó a cabo la clonación de los insertos shRNA en el vector pGreenPuro, y se realizó la transfección en las células empaquetadoras 293FT como se detalla en la sección de Material y Métodos, y posteriormente se realizó la transducción en las células RAW 264.7. Las células silenciadas en la región 5'UTR de FASTK fueron seleccionadas en presencia de puromicina $(7 \mu \mathrm{g} / \mathrm{ml})$ y monitorizadas mediante microscopia de fluorescencia y qRT-PCR. Estos shRNA mostraron una disminución en la expresión del gen, como se muestra en la figura 32 . En los experimentos del estudio planteado se empleó el knockdown shUTR 18-2, a partir de ahora denominado shUTR.

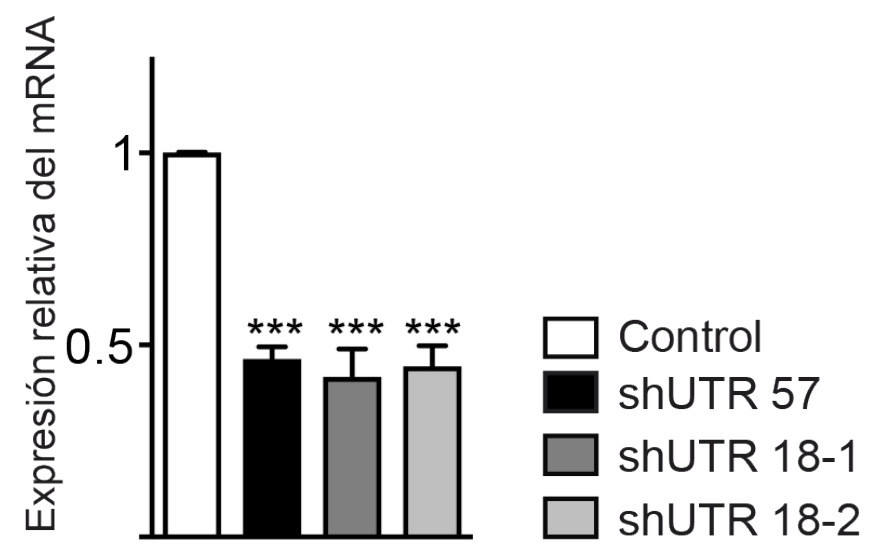

Figura 32. Gráfico en el que se muestra la expresión relativa de los diferentes ShRNA (shUTR57, shUTR 18-1 y shUTR 18-2) contra la región 5'UTR de FASTK obtenidos en la línea celular RAW 264.7 mediante $q R T-P C R$, aplicando la fórmula $2^{-4 \Delta C t}$. El control empleado fue el vector vacio (shpGreenPuro). El gen $\beta$-actina ha sido utilizada como normalizador. Análisis estadístico $t$ de Student, unpaired t test, two-tailed. Los resultados se representan como la media \pm error estándar de 3 experimentos independientes. ${ }^{* * *}$ indica $p<0.001$.

Se empleó un shRNA contra la región 5'UTR porque la expresión puede ser rescatada con vectores que expresan la región codificante de FASTK (y no poseen la 5' UTR). Las células que expresaban shUTR se transfectaron con los siguientes constructos: el constructo que codificaba solo la proteína roja fluorescente RFP (RFP), el constructo que contenía dos sitios de iniciación de la traducción y codifica la isoforma mitocondrial y citoplasmática de FASTK (FASTK WT RFP), y el constructo FASTK delecionado que comienza en la metionina interna en la posición 35 , mitoFASTK, (FASTK $\triangle 1$ 1-34). Todos ellos expresan RFP en la terminación carboxilo y fueron cedidos gentilmente por la Dra. Nancy Kedersha y el Dr. Paul Anderson (Universidad de Harvard, Boston, MA). Se llevó a cabo la digestión de los dos constructos (FASTK WT RFP y FASTK $\Delta 1-34$ ) con las enzimas de restricción Kpnl/HindIII (Figura 33). 


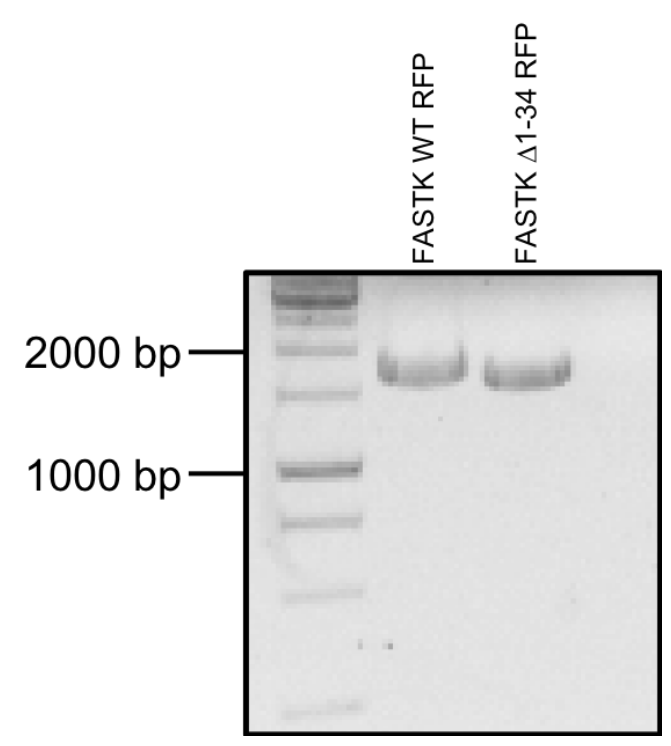

Figura 33. Imagen en la que se muestra el resultado obtenido mediante digestión con las enzimas de restricción Kpnl/HindIII de los constructos FASTK WT RFP (1649bp) y FASTK $\Delta 1-34$ (1547 bp), en el orden descrito.

Las células RAW 264.7 silenciadas en la región 5'UTR (shUTR) fueron transfectadas con RFP (como control), FASTK WT RFP, y FASTK $\Delta 1-34$.

Se realizaron curvas de respuesta a diferentes dosis de G418 (0.1 a $2 \mathrm{mg} / \mathrm{ml})$, con el fin de determinar la concentración más baja de antibiótico capaz de matar al $100 \%$ de las células no transfectadas en el transcurso de una semana, que resultó ser de $1 \mathrm{mg} / \mathrm{ml}$. Las células transfectadas se seleccionaron con $1 \mathrm{mg} / \mathrm{ml} \mathrm{G} 418$ durante 15 días, y en presencia de puromicina $(7 \mu \mathrm{g} / \mathrm{ml})$ ya que el vector donde se silenció FASTK para la región 5'UTR tenía un gen de resistencia a la puromicina, como ya se ha indicado. La expresión de los constructos RFP se evaluó utilizando el microscopio de fluorescencia (Texas-Red).

Una vez que obtuvimos las células para los experimentos de rescate, se realizaron los ensayos de fagocitosis. Las bacterias fueron marcadas con TRITC y el índice fagocítico se evaluó como se ha descrito en la figura 29. Como se muestra en la figura 34, la re-expresión de FASTK $\Delta 1$-34, fue capaz de rescatar el fenotipo fagocítico de las células delecionadas en FASTK. EI IF de los macrófagos shUTR frente a E.coli está aumentado respecto a las células control $(232.4 \pm 10.13 \%$ versus $100 \pm 0.77 \%$, $\mathrm{p}<0.0001)$ y el IF frente a E.coli está disminuido en las células shUTR + WT-RFP en comparación con los macrófagos shUTR (112.3 $\pm 10.86 \%$ versus $232.4 \pm 10.13 \%$, $\mathrm{p}<0.0001$ ). Como se puede observar (Figura 34), hay una mayor disminución en el índice fagocítico de E.coli en los macrófagos shUTR $+\Delta 1-34-R F P$ frente a las células 
shUTR $(71.70 \pm 4.38 \%$ versus $232.4 \pm 10.13 \%, p<0.0001)$. Asímismo, se confirma el mismo fenotipo descrito con la bacteria S.aureus, dado que el IF para S.aureus está aumentado en las células shUTR respecto a las células control (174.8 $\pm 8.63 \%$ versus $100 \pm 1.30 \%, p<0.0001)$, sin embargo el IF para S.aureus está disminuido en los macrófagos shUTR + WT-RFP en comparación con los macrófagos shUTR $(92.49 \pm 3.71 \%$ versus $174.8 \pm 8.63 \%, p<0.0001)$. Precisamente, se observa una mayor disminución en el índice fagocítico para S.aureus en las células shUTR $+\Delta 1-34-R F P$ respecto a las células shUTR $(63.93 \pm 4.57 \%$ versus $174.8 \pm 8.63 \%, p<0.0001)$.

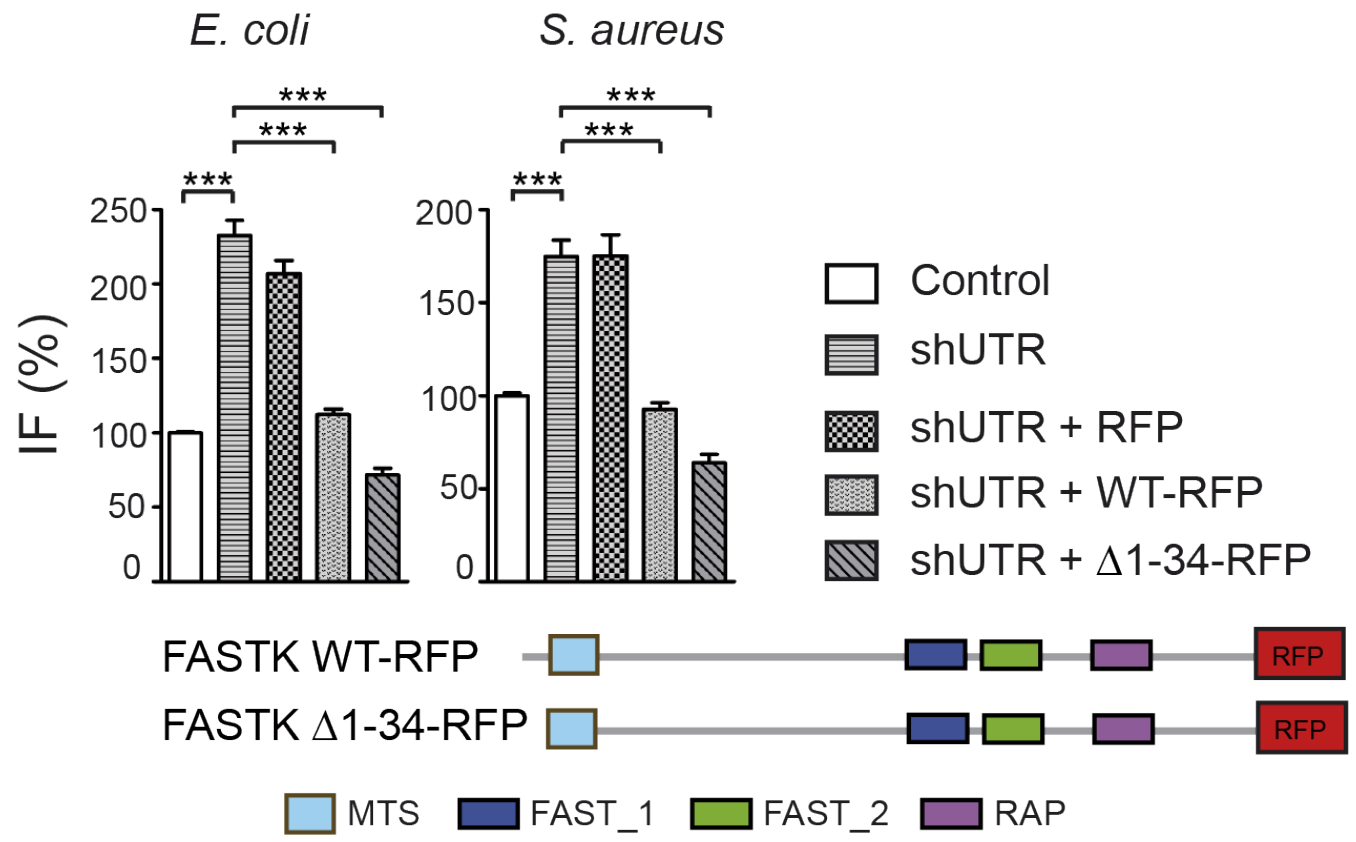

Figura 34. Índice fagocítico de E.coli y S.aureus en las células RAW 264.7 en las que se ha silenciado FASTK y los constructos de rescate. Las células que expresan shUTR se transfectaron con RFP, FASTK WT RFP y FASTK $\triangle 1-34$ RFP. El control es el vector vacio (shpGreenPuro). En la imagen inferior se representa de forma esquemática los contructos empleados en el estudio: FASTK WT-RFP y FASTK $41-34$. MTS, señal de localización mitocondrial; tres dominios conservados de los miembros de la familia FASTK: FAST_1, FAST_2 y RAP. Media \pm error estándar ( $n>6$ experimentos independientes), ${ }^{* * *} p<0.001$ (t de Student).

De nuevo, se llevaron a cabo los experimentos de fagocitosis con el ensayo de protección a la gentamicina a la hora de la infección con E.coli y S.aureus. El número de colonias de E.coli y S.aureus en los macrófagos shUTR $+\Delta 1-34-R F P$ muestran una disminución en el número de colonias en comparación con los macrófagos shUTR. En E.coli se obtuvieron $192.5 \pm 15.88$ UFC/pocillo versus $585.8 \pm 250.3$ UFC/pocillo, $p<0.05$. Mientras que en S.aureus se obtuvieron $7317 \pm 526.9$ UFC/pocillo versus $18183 \pm 1674$ UFC/pocillo, $p=0.0035$ (Figura 35). 


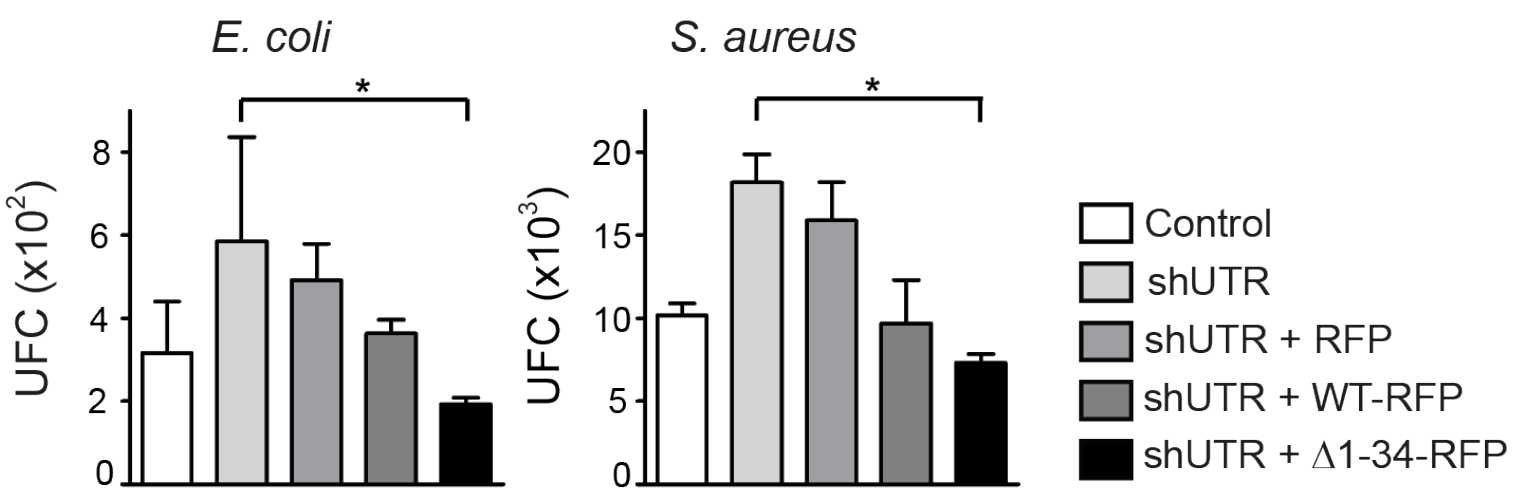

Figura 35. Capacidad fagocítica en E.coli y S.aureus en las células RAW 264.7 en las que se ha silenciado FASTK y los constructos de rescate. Se representa la media \pm error estándar $(n=3)$. ${ }^{*} p<0.05$, Análisis estadístico $t$ de Student, unpaired test, twotailed.

Estos resultados demostraron que mitoFASTK es un regulador de la fagocitosis de bacterias en los macrófagos a través de la regulación de la actividad del complejo I de la mitocondria.

\section{Estudio de la activación de AMPK en la fagocitosis no opsónica de bacterias en los macrófagos}

La proteína quinasa activada por monofosfato de adenosina (AMPK) es un complejo heterotrimérico compuesto por una subunidad catalítica $\alpha$ y dos subunidades reguladoras $\beta$ y $\gamma$. Mantiene la homeostasis energética limitando la utilización de energía y/o promoviendo la producción de energía, y se expresa en las células inmunitarias, como las células dendríticas, los macrófagos, los linfocitos y los neutrófilos. Está activado por la fosforilación de la treonina 172 (Thr172) dentro de la subunidad catalítica $\alpha$ (Carling et al., 2017). La activación de AMPK reorganiza el citoesqueleto, incluyendo la formación de microtúbulos y actina durante la fagocitosis (Distelmaier et al., 2009; Bae et al., 2011).

Existen evidencias previas de que la disfunción del complejo I desencadena cambios transitorios y sostenidos en el metabolismo y está acompañado por la fosforilación de AMPK $\alpha$, un sensor energético celular crucial. Se ha demostrado que el suministro de glucosa y la subunidad AMPK $\alpha$ son importantes para la supervivencia celular durante la disfunción del complejo I (Distelmaier et al., 2009), y AMPK $\alpha$ mejora la capacidad fagocítica de los macrófagos y los neutrófilos (Bae et al., 2011). Esto nos llevó a preguntarnos si una disminución en la actividad del complejo I aumentaría la fagocitosis bacteriana mediada por los macrófagos a través de la activación de AMPK.

Para verificar esta hipótesis, se examinó el estado de fosforilación de AMPK $\alpha$ (Thr172) y los niveles de AMPK totales en los macrófagos peritoneales WT y FASTK 
KO. Los macrófagos peritoneales de estos ratones fueron expuestos a las bacterias E.coli y S.aureus, y estimulados con AICAR (5-aminoimidazol-4-carboxamida-1- $\beta$ - $D$ ribofuranosida) (1mM) durante 30 minutos. Los lisados celulares se emplearon para realizar el Western blot utilizando los anticuerpos específicos fosfo-AMPK $\alpha$ (Thr172) $(\mathrm{pAMPK} \alpha), \mathrm{AMPK} \alpha$ y actina. Curiosamente, el nivel basal de fosforilación de AMPK $\alpha$ (pAMPK $\alpha$ ) estaba aumentado dos veces en los macrófagos FASTK KO en comparación con las células WT (Figura 36A y Figura 37). Y los niveles totales de AMPK $\alpha$ no mostraron cambios (Figura 36B).

La estimulación con AICAR se utilizó como control positivo en la fosforilación de AMPK. Dado que AICAR, análogo de adenosina, es captado en las células a través de los transportadores de adenosinas, y se fosforila en AICAR monofosfato (ZMP, 5-aminoimidazole-4-carboxamide-1- $\beta$-D-ribofuranosyl 5'-monophosphate) por la adenosina quinasa. El ZMP es un análogo del AMP celular que se une a la subunidad AMPK $\gamma$ y de esta forma AICAR activa AMPK (Kim et al., 2016).

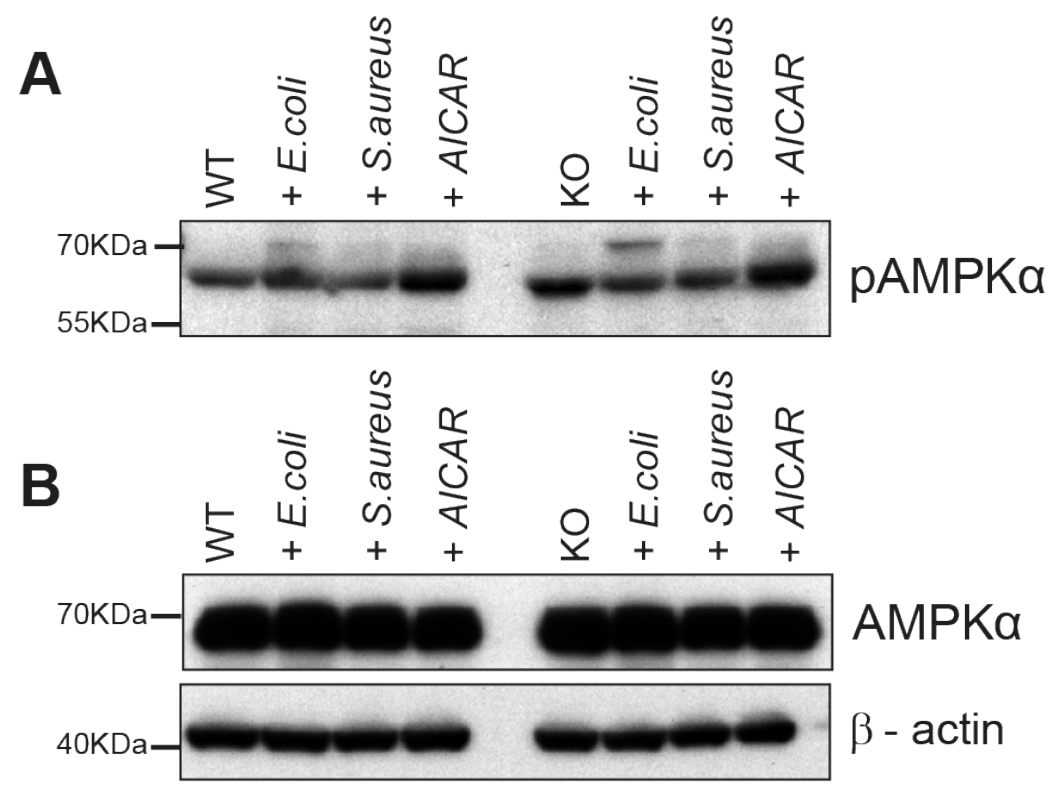

Figura 36. AMPK $\alpha$ tiene un papel importante en la modulación de FASTK en la fagocitosis bacteriana. A. Western blot representativo con los lisados celulares de los macrófagos FASTK KO y WT expuestos a las bacterias y estimulados con AICAR (1 mM) durante $30 \mathrm{~min}$, utilizando el anticuerpo fosfo-AMPK $\alpha$ (Thr172). B. Western blot representativo de los lisados celulares de los macrófagos FASTK KO y WT expuestos a las bacterias y estimulados con AICAR (1 mM) utilizando los anticuerpos AMPK $\alpha$ y actina. La banda de AMPK y pAMPK tiene un peso de 62KDa.

La exposición de bacterias conduce a un aumento en la fosforilación de AMPK $\alpha$ que fue significativo en los macrófagos WT. Sin embargo, en el caso de los macrófagos FASTK KO, el aumento que se observa no resultó significativo tras la estimulación con 
las bacterias, probablemente debido a que AMPK $\alpha$ está más fosforilado en condiciones basales (Figura $\mathbf{3 8}$ ).

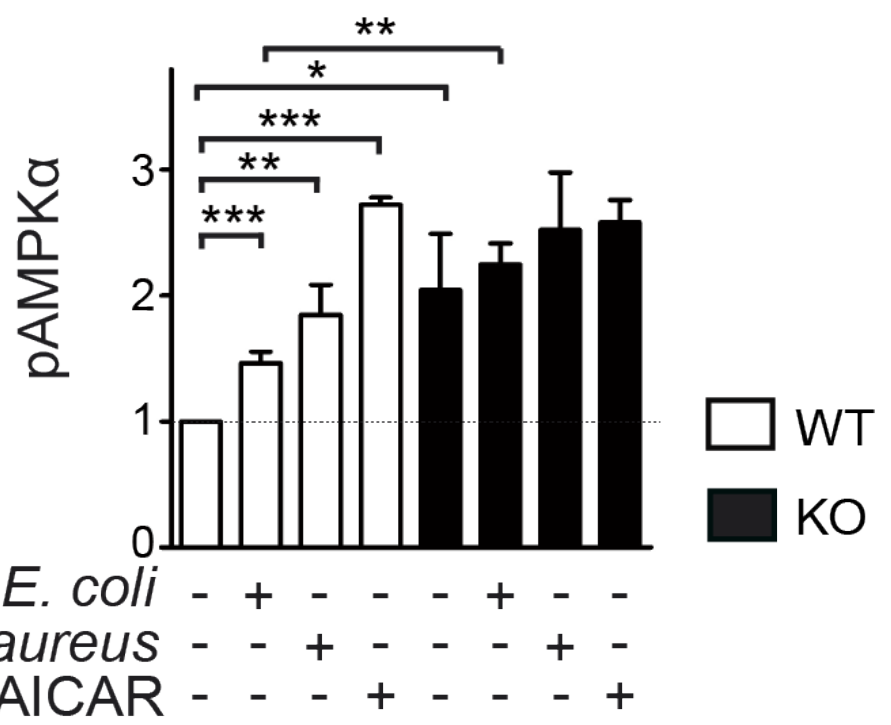

Figura 37. Cuantificación de fosfo-AMPK $\alpha$ (Thr172) en las señales obtenidas por Western blot. Los valores fueron normalizados a los macrófagos WT no tratados (control). Se representan los valores como media \pm SEM de $n=4$ experimentos independientes. ${ }^{*} p<0.05$, ${ }^{* *} p<0.01,{ }^{* * *} p<0.001$ (t de Student). Se utilizó el programa ImageJ para la cuantificación.

Este experimento demuestra que AMPK $\alpha$ tiene un papel clave en la modulación de la fagocitosis bacteriana mediado por FASTK. La activación de AMPK se relaciona con el aumento en la fagocitosis no opsónica de E.coli y S.aureus en los macrófagos peritoneales de ratón.

\subsection{Efecto del inhibidor de AMPK durante la fagocitosis no opsónica en los macrófagos}

Estudios previos han demostrado que el compuesto $C$ (compound $C$ ) inhibe de forma específica la activación de AMPK en varias poblaciones celulares, incluyendo macrófagos y neutrófilos (Zhao et al., 2008; Jeong et al., 2009).

Tras observar que AMPK está activado en las células deficientes en FASTK que expresan un fenotipo de aumento en la actividad fagocítica de bacterias, nos propusimos estudiar el fenotipo fagocítico en los macrófagos delecionados y silenciados en FASTK, examinando los efectos del inhibidor de AMPK, compuesto C.

Antes de comenzar con los experimentos se verificó la viabilidad celular en presencia del compuesto $C$ por exclusión de azul de tripán. Al menos 100 células de cuatro campos diferentes se contaron, demostrando que el inhibidor no era tóxico para las células. 
El siguiente paso fue incubar los macrófagos primarios peritoneales murinos en ausencia o presencia del inhibidor de AMPK, compuesto $\mathrm{C}(10 \mu \mathrm{M}, 30 \mathrm{~min})$ antes de los ensayos de fagocitosis. Se expusieron a las células durante 60 minutos en presencia de bacterias no opsonizadas E.coli y S.aureus marcadas con TRITC e inactivadas con calor. Tras la incubación con bacterias en presencia o ausencia del compuesto $C$, se cuantificaron los índices fagocíticos, a través de la observación en el microscopio de fluorescencia.

Los datos fueron normalizados a la media del índice fagocítico de las células WT. Tal como se puede observar en la figura 38, el índice fagocítico fue significativamente mayor en las células FASTK KO frente a los controles WT, como se demostró en experimentos previos del laboratorio. Cuando está presente el inhibidor de AMPK, compuesto $\mathrm{C}$, se produjo una disminución significativa en la fagocitosis de bacterias E.coli y S.aureus entre las células FASTK KO y los controles WT tratadas con el compuesto $\mathrm{C}$ en comparación con el índice fagocítico de los macrófagos FASTK KO y WT no tratados (Figura 38). Observamos que el IF para E.coli está disminuido de forma significativa en los macrófagos FASTK KO tratados con compuesto $\mathrm{C}$ respecto a los macrófagos FASTK KO (87.04 $\pm 3.99 \%$ versus $160.7 \pm 2.86 \%, p<0.0001)$. De forma similar, el IF para S.aureus también está disminuido en los macrófagos de los ratones FASTK KO tratados con el compuesto C respecto a los macrófagos KO (101.5 $\pm 2.53 \%$ versus $171.5 \pm 6.61 \%, p<0.0001)$.

Estos resultados demuestran que los macrófagos FASTK KO revirtieron el fenotipo fagocítico WT mediante la adición del compuesto C. 


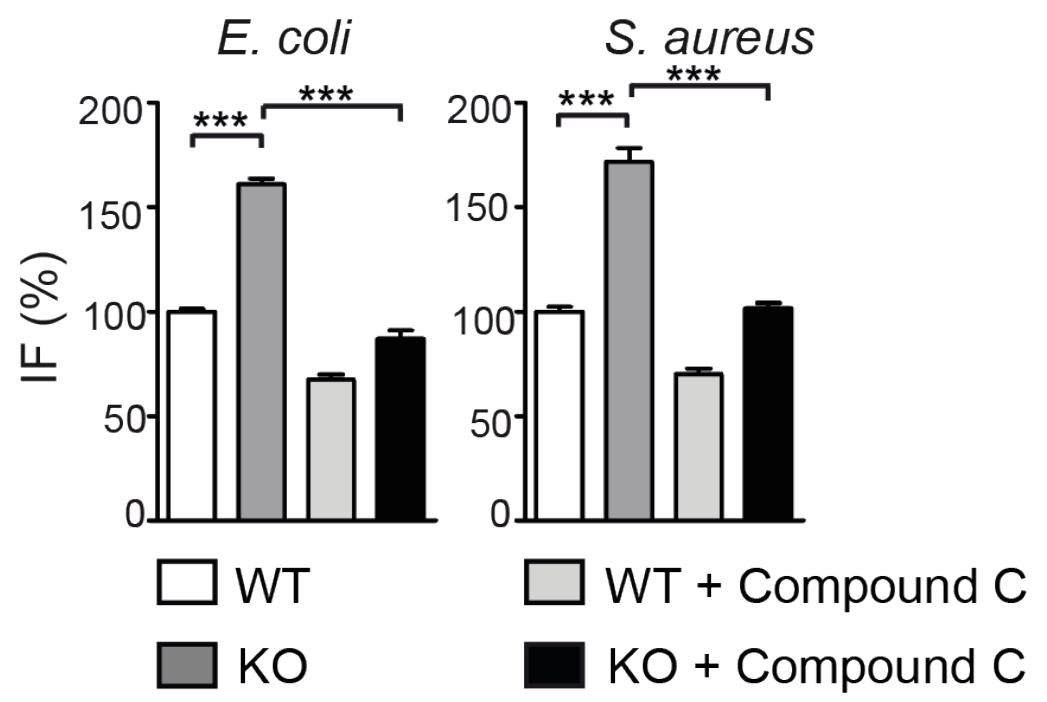

Figura 38. Índice fagocítico con el inhibidor compuesto $\mathrm{C}$ (compound $\mathrm{C}$ ) en los macrófagos peritoneales murinos FASTK KO y WT. Estas células se incubaron en presencia y ausencia del compuesto $C(10 \mu \mathrm{M}, 30 \mathrm{~min})$ antes de ser estimuladas con las bacterias E.coli y S. aureus. $n=3$ experimentos independientes. ${ }^{* *} p<0.001$. Se empleó la prueba estadística $t$ de student, unpaired $t$ test, two-tailed. Se utilizó como control positivo de la fagocitosis las células FASTK KO en ausencia del inhibidor.

Teniendo en cuenta los resultados obtenidos, quisimos validarlos en otro modelo. Se ensayó este inhibidor en la línea celular estable RAW 264.7 silenciada en FASTK. Se examinó la fagocitosis utilizando bacterias no opsonizadas E.coli y S.aureus marcadas con TRITC e inactivadas con calor. Los datos fueron normalizados a la media del índice fagocítico de las células RAW 264.7 que expresaban el vector vacío pGreenPuro shRNA (shpgreen o control). Como se puede observar en la figura 39, se obtuvieron resultados similares con las líneas celulares estables. Pudimos comprobar que la inhibición de la señalización de AMPK por el compuesto $C$ disminuye la capacidad de fagocitosis en las células silenciadas en FASTK. El IF frente a E.coli está disminuido de forma significativa en los macrófagos shFASTK tratados con el compuesto $\mathrm{C}$ respecto a los macrófagos shFASTK (100.8 $\pm 8.40 \%$ versus $190.1 \pm 5.16 \%, p=0.0008)$. De forma similar, el IF frente a S.aureus también está disminuido en los macrófagos de los ratones shFASTK tratados con compuesto $C$ respecto a los macrófagos shFASTK $(95.46 \pm 1.77 \%$ versus $150.2 \pm 3.19 \%, p=0.0001)$.

Estos experimentos confirmaron que en el modelo shFASTK, el índice fagocítico frente a las dos cepas bacterianas en presencia del compuesto $C$ también disminuyó de forma significativa. Así pues, el compuesto $C$ es capaz de revertir el fenotipo de la fagocitosis en la línea celular RAW 264.7 silenciada en FASTK. 
E. coli

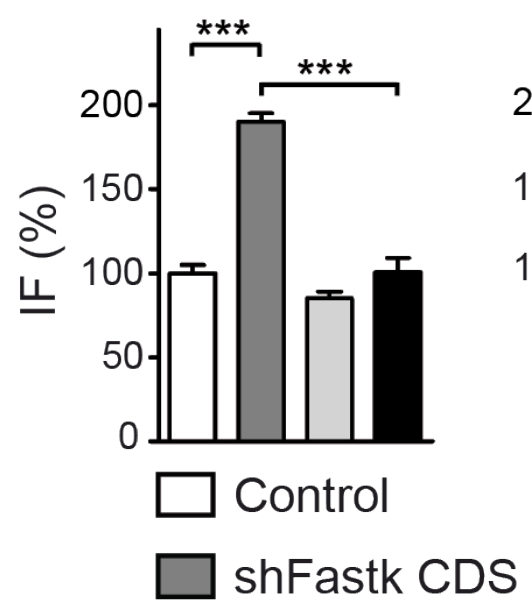

S. aureus

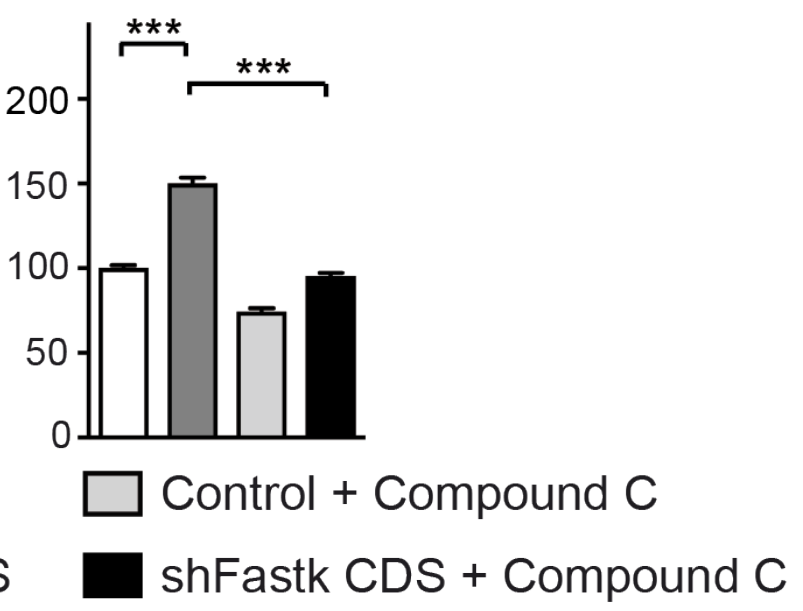

Figura 39. Índice fagocítico con el inhibidor compuesto $C$ (compound $C$ ) en células RAW 264.7 silenciadas en FASTK. Las líneas celulares se incubaron en presencia y ausencia del compuesto C (10 $\mu \mathrm{M}, 30 \mathrm{~min})$ antes de ser estimuladas con las bacterias E.coli y S.aureus. La relación célula:bacterias fue 1:50. El índice fagocítico se calculó multiplicando el porcentaje de macrófagos que habían fagocitado por la media de bacterias fagocitadas por macrófago. El control empleado fue el vector vacio (shpGreenPuro) y se utilizó como control positivo de la fagocitosis las células shFASTK en ausencia del inhibidor. $n=3$ experimentos independientes. ${ }^{* * *} p<0.001$. Se empleó la prueba estadística $t$ de student, unpaired t test, twotailed.

En conjunto, estos resultados demuestran que AMPK es un modulador clave en el papel de FASTK en la fagocitosis no opsónica. Se ha demostrado que el tratamiento con el compuesto $\mathrm{C}$ revierte el fenotipo fagocítico en los macrófagos primarios deficientes en la proteína FASTK y en los macrófagos RAW 264.7 silenciados en FASTK (shFASTK).

\section{Análisis de la generación de los radicales libres de oxígeno mitocondriales en los macrófagos FASTK KO}

La disfunción del complejo I, principal generador de ROS mitocondriales, está relacionado con un aumento en los niveles de las especies reactivas de oxígeno mitocondriales (mitoROS) (Koopman et al., 2005).

Los ROS son importantes como mensajeros intracelulares y curiosamente, se ha demostrado que mitoROS se requiere para la activación de AMPK (Sena y Chandel, 2012). Algunos trabajos presentes en la literatura han demostrado que AMPK puede ser activada por ROS (Rabinovitch et al., 2017; Mackenzie et al., 2013), y se ha demostrado que el peroxinitrito es una señal clave para que aumente la fosforilación de AMPK (An et al., 2007). Del mismo modo, otros autores han observado una activación de AMPK en condiciones de estrés oxidativo (Zou et al. 2004), y se ha evidenciado que la activación de AMPK coincide con el aumento de ROS (Anneda et al., 2008). Tras 
observar en nuestro estudio que AMPK se encontraba activada durante la fagocitosis no opsónica de E.coli y S.aureus, nos planteamos examinar la generación de los radicales libres de oxígeno mitocondriales en la fagocitosis.

Se evaluó la generación de mitoROS utilizando la sonda Mitosox Red $(2.5 \mu \mathrm{M})$, colorante fluorógeno que se dirige a las mitocondrias de células vivas, y produce fluorescencia roja cuando se oxida con el anión superóxido dentro de la mitocondria. Se añadió Mitosox Red al medio de cultivo en los macrófagos WT y FASTK KO, así las células fueron pre-tratadas antes de ser estimuladas con las bacterias.

Durante la fagocitosis de E.coli y S.aureus, los mitoROS adquiridos por citometría de flujo se han analizado como la intensidad media de fluorescencia (MFI, median fluorescence intensity) y normalizados frente al control WT.

Los niveles basales en los macrófagos WT muestran una intensidad media de fluorescencia de $0.50 \pm 0.06$, sin embargo, los macrófagos FASTK KO muestran una intensidad media de fluorescencia de $0.80 \pm 0.30(p=0.30)$ (Figura 40).

Los resultados obtenidos en los macrófagos de tipo salvaje (WT) (Figura 40A) expuestos con E.coli tienen una intensidad media de fluorescencia de $2.20 \pm 0.47$ frente al control $0.50 \pm 0.06 \mathrm{MFI}(\mathrm{p}=0.011)$, y en los macrófagos incubados con S.aureus muestran un aumento significativo en la intensidad media de fluorescencia de $2.90 \pm 0.20 \mathrm{MFI}$ frente al control $0.50 \pm 0.06 \mathrm{MFI}(p<0.0001)$. Por lo tanto, encontramos que los macrófagos primarios WT incubados en presencia de bacterias muestran un aumento significativo en el MFI para E.coli y S.aureus.

En paralelo se analizaron los resultados de los macrófagos primarios deficientes en la proteína FASTK (KO) (Figura 41B) expuestos a E.coli, y se observó que muestran una intensidad media de fluorescencia de $3.60 \pm 0.57 \mathrm{MFI}$ frente al control $0.80 \pm 0.30$ MFI $(p=0.011)$, mientras que en los macrófagos FASTK KO expuestos a S.aureus se observó un aumento significativo en la intensidad media de fluorescencia de $4.30 \pm 0.44$ MFI frente al control $0.80 \pm 0.30 \mathrm{MFI}(p=0.0027)$. Estos resultados son preliminares pero muestran que los macrófagos que se exponen a bacterias E.coli y S.aureus producen un aumento significativo en la intensidad media de fluorescencia (generación de mitoROS), que es mayor en los macrófagos FASTK KO en comparación con los macrófagos WT control. 
A
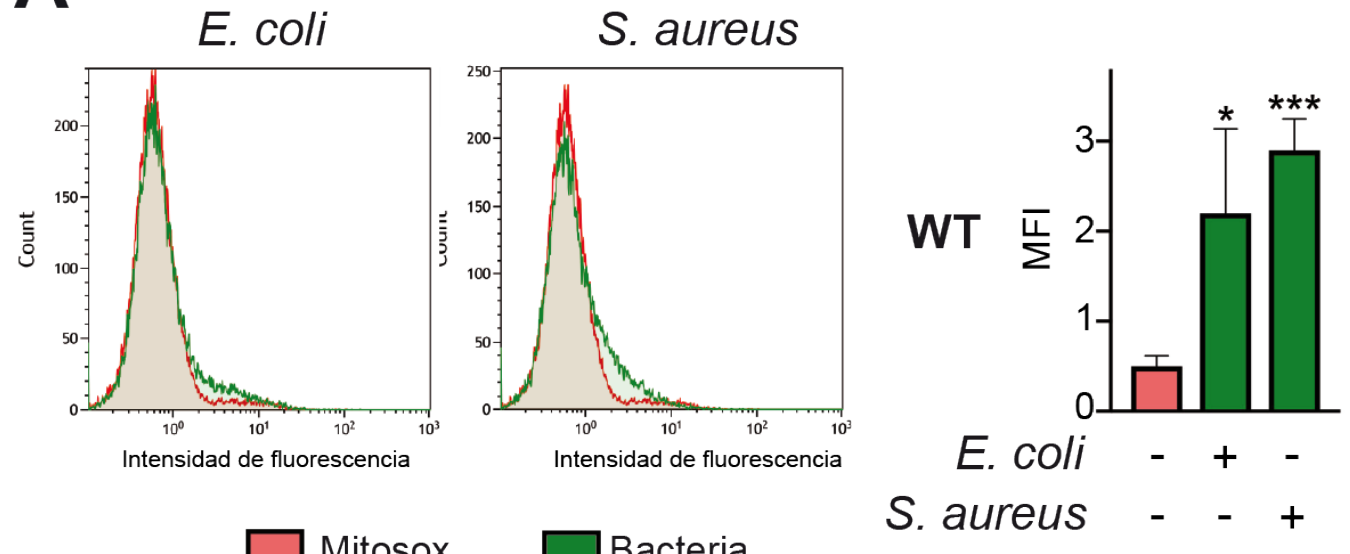

B

Mitosox

Bacteria

E. coli

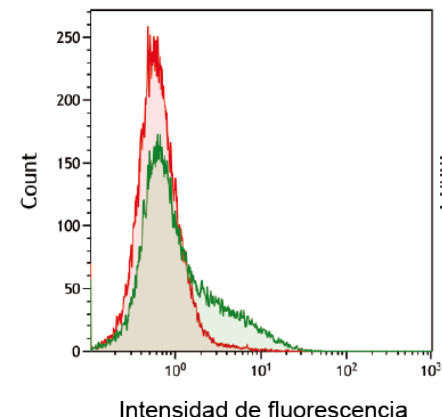

S. aureus

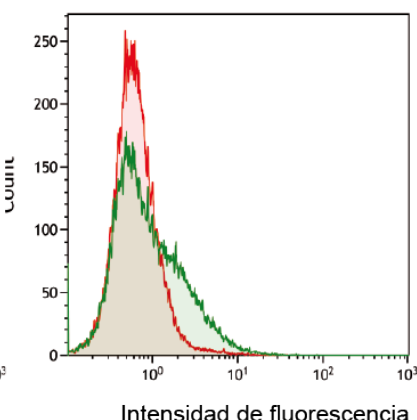

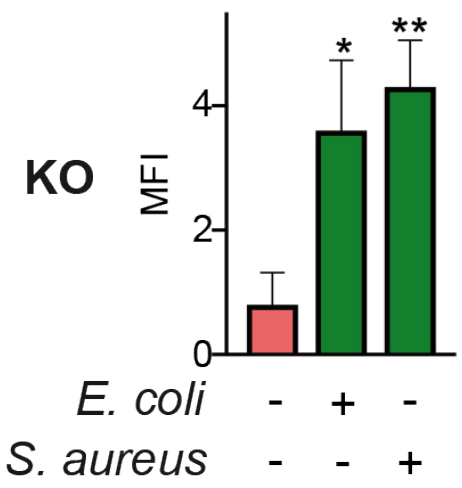

Figura 40. Generación de los radicales libres de oxígeno mitocondriales en los macrófagos FASTK KO. Análisis de la generación de los ROS mitocondriales en ratones FASTK KO y de tipo salvaje (WT). Los macrófagos peritoneales de los ratones FASTK KO y WT se incubaron en presencia y ausencia de bacterias E.coli y S.aureus durante 15 minutos a $37^{\circ} \mathrm{C}$. Las células fueron marcadas con $2.5 \mu \mathrm{M}$ de MitoSOX, y posteriormente se analizaron por citometría de flujo (FL2). A. Se muestran los contajes de la intensidad de fluorescencia y los histogramas representativos de citometría de flujo en los macrófagos de tipo salvaje. B. Se muestran los contajes de la intensidad de fluorescencia y los histogramas representativos de citometría de flujo en los macrófagos peritoneales murinos FASTK KO. $n=3$ experimentos independientes. ${ }^{*} p<0.05,{ }^{* *} p<0.01,{ }^{* * *} p<0.001$ ( $t$ de Student, Unpaired $t$ test, two-tailed). La intensidad de fluorescencia se normalizó frente al control WT. 

DISCUSIÓN 



\section{DISCUSIÓN}

El estudio realizado en esta Tesis Doctoral muestra nuevas evidencias in vitro del papel de la isoforma mitocondrial de FASTK (mitoFASTK) en la regulación de la fagocitosis no opsónica de bacterias por los macrófagos.

En este trabajo demostramos que los mecanismos moleculares responsables del aumento de la fagocitosis de bacterias en ausencia de FASTK son: la disminución de la actividad del complejo I y la activación de AMPK. Esto se demuestra porque: a) el bloqueo del complejo I con rotenona y el silenciamiento de las subunidades del complejo I, NDUFS3 y NDUFS4, mediante shRNA, aumentan la captación no opsónica de bacterias; mientras que la reexpresión de mitoFASTK restablece la fagocitosis no opsónica de los macrófagos, es decir, rescata el fenotipo; b) los macrófagos de los ratones FASTK KO muestran un aumento en la fosforilación de AMPK y la inhibición de la fosforilación de AMPK revierte el fenotipo fagocítico. Por tanto, se ha demostrado la importancia de la mitocondria, en concreto, la actividad del complejo I en la regulación de la fagocitosis no opsónica en ausencia de FASTK.

En esta tesis se definen vías de señalización que pueden ser importantes para la regulación de las funciones fagocíticas del macrófago.

A continuación, discutimos algunos de los puntos clave de esta tesis.

\section{El complejo I mitocondrial en la regulación de la fagocitosis no opsónica}

La fagocitosis es un proceso crítico de las células del sistema inmunitario innato para eliminar las bacterias, que utiliza receptores fagocíticos que pueden ser opsónicos o no opsónicos. Los receptores fagocíticos opsónicos incluyen el receptor Fc y los receptores del complemento que reconocen anticuerpos o partículas opsonizadas por el complemento, respectivamente, lo que lleva a la internalización del microorganismo o partícula. En la fagocitosis no opsónica (o independiente de opsoninas), los fagocitos reconocen y fagocitan microorganismos a través de los receptores de reconocimiento de patrones que detectan directamente los componentes de la pared celular bacteriana o fúngica (PAMPs) (Lim et al., 2018; Goodridge et al., 2012). Los receptores scavenger son los principales receptores de macrófagos implicados en la fagocitosis independiente de opsoninas de las bacterias Gram negativas y Gram positivas (Peruń et al., 2017).

En este trabajo de investigación, se ha estudiado la captación fagocítica no opsónica de bacterias mediada por los macrófagos. Este proceso complejo de ingestión está mediado por receptores que reconocen adhesinas en la superficie microbiana, y es 
importante como mecanismo de defensa del huésped contra patógenos extracelulares y como un medio de supervivencia en el huésped para patógenos intracelulares (Ofek et al., 1995). A diferencia de la fagocitosis basada en la opsonización, este tipo de fagocitosis no opsónica depende de la clase de partículas que se internalizan, y la heterogeneidad, expresión, complejidad y señalización del receptor, y la especificidad del ligando bacteriano. Esta fagocitosis es crítica en las fases iniciales de la infección, antes de la llegada del plasma al sitio de infección, y en ciertos lugares anatómicos, como los pulmones (Heale et al., 2001), espacio cerebroespinal y tracto urinario, donde los niveles de opsoninas son bajos. Cuando hay una exposición a un pequeño número de microorganismos o antes de que ocurra la inflamación generalizada en respuesta a la invasión bacteriana, se promueve el aclaramiento de las bacterias, y se puede determinar la eficacia de la colonización al inicio de la infección (Webster et al., 2008). Las interacciones no opsónicas, -que producen y liberan citoquinas, producción de superóxido, polimerización de actina, y la fagocitosis-, son importantes en la respuesta inmunitaria de algunos microorganismos como E.coli, Pseudomonas aeruginosa, Neisseria meningitidis, micobacterias y levaduras (Mork y Hancock, 1993; Ohman et al., 1982; Stokes et al., 1998; Zaffran et al., 1998).

Es importante destacar que la fagocitosis de algunas bacterias (como Pseudomonas aeruginosa) ocurre cuando la opsonización está ausente o no es eficaz. Por lo tanto, la fagocitosis no opsónica es un método muy eficiente de ingestión microbiana y parece estar bien conservada entre fagocitos humanos y murinos (Heale et al., 2001).

El mecanismo por el cual las bacterias son fagocitadas por los macrófagos en ausencia de componentes séricos está poco definido. Los procesos no opsónicos difieren en una serie de aspectos de los mecanismos opsónicos. Se ha descrito que las GTPasas Rac y RhoA se activan durante la captación de partículas no opsonizadas, mientras que durante la captación de las partículas opsonizadas solo se activa una de ellas (Rac solo se activa durante la captación mediada por FcR, y RhoA solo se activa durante la captación mediada por CR3). En ambos mecanismos de fagocitosis se genera una respuesta de $\mathrm{PI}(3,4,5) \mathrm{P}_{3}$ y F-actina en el sitio de unión de la partícula (Gilberti y Knecht, 2014).

En este trabajo se investiga la disminución de la actividad del complejo I mitocondrial en la fagocitosis no opsónica de bacterias por los macrófagos murinos peritoneales deficientes en la proteína FASTK. Los resultados obtenidos evidencian que la inhibición del complejo I con el inhibidor rotenona y el silenciamiento mediante shRNA 
contra dos subunidades del complejo I (NDUFS3 y NDUFS4), conducen a un aumento significativo en la fagocitosis bacteriana mediada por los macrófagos peritoneales y también en la línea celular RAW 264.7. Sin embargo, observamos que en presencia de zymosán y partículas inertes de látex (beads) no hay diferencias en el índice fagocítico entre los dos tipos de macrófagos y los controles. Nuestros datos han sido comparados con los obtenidos por otros estudios realizados recientemente. Está descrito que la disminución en la actividad del complejo I también está relacionada con otros procesos que comparten algunos mecanismos comunes a la fagocitosis como la eferocitosis y la autofagia. Por ejemplo, en la autofagia las NADPH oxidasas tienen un papel central en su regulación a través de la generación de ROS (Huang et al., 2009). La fagocitosis está involucrada en una variedad de patologías cerebrales. En un modelo de enfermedad de Parkinson demuestran que, al emplear la rotenona en un cultivo de neuronas, se induce una activación de la microglia, lo que lleva al aumento de la actividad fagocítica de neuronas apoptóticas y partículas inertes (Emmrich et al., 2013), y se acompaña de una disminución de la respiración mitocondrial y reducción del potencial mitocondrial (Palorini et al., 2013). De forma similar, el silenciamiento de GRIM-19, una subunidad del complejo I mitocondrial, en células HeLa induce un aumento en la autofagia (Yue et al., 2016). Además, se conoce que el fármaco antidiabético metformina inhibe el complejo I y se ha descrito que aumenta la fagocitosis en la microglia (Labuzek et al., 2010).

Como hemos comentado anteriormente, el complejo I (NADH deshidrogenasa) es un complejo multiproteico, compuesto por 45 subunidades de proteínas diferentes y representa el punto de entrada de la mayoría de electrones de la cadena de transporte de electrones. El ensamblaje de este complejo está influenciado por el medio oxidativo dentro de la cadena de transporte de electrones o por el ensamblaje de otros componentes de la cadena, incluyendo el complejo III o citocromo c oxidasa (Enríquez et al., 2016; Acín-Pérez et al., 2004; Diaz et al., 2006).

Es importante mencionar que cuando decidimos generar los shRNAs para disminuir la actividad del complejo I de la mitocondria en la línea celular RAW 264.7, seleccionamos las subunidades NDUFS3 y NDUFS4. NDUFS3 es una subunidad catalítica, integral del módulo $Q$ y se conoce porque tiene un papel importante en el ensamblaje del complejo I (Janssen et al., 2006; Koopman et al., 2010; Vogel et al., 2007), mientras que NDUFS4 es una subunidad accesoria que se requiere para la estabilidad del mismo (Kruse et al., 2008; Kahlhöfer et al., 2017). La deficiencia del complejo I de la cadena respiratoria ocurre en una serie de enfermedades genéticas debidas a mutaciones de alguno de sus componentes. Distintas mutaciones que afectan 
a varios de estos genes dan lugar al síndrome de Leigh (o encefalomielopatía necrotizante subaguda), una enfermedad neurodegenerativa que se caracteriza por una pérdida progresiva de las capacidades mentales y de movimiento y, por lo general, produce la muerte en un plazo de 2 a 3 años desde el inicio de los síntomas, generalmente debido a una insuficiencia respiratoria (Benit et al., 2004; Jaokar et al., 2013; Ortigoza-Escobar et al., 2016; Pagniez-Mammeri et al., 2012).

El papel de FASTK y el complejo I en la regulación de la fagocitosis de bacterias mediada por los macrófagos representa un hallazgo importante que requiere más investigación. Hay que destacar que la deficiencia del complejo I no conduce a un aumento en la fagocitosis del zymosán ni de las partículas inertes de látex (beads), como ya hemos mencionado. Esto sugiere que el estímulo de este aumento está asociado con las propias bacterias que producen la disminución de la actividad del complejo I en la fagocitosis no opsónica. El efecto se ha demostrado mayor en las bacterias Gram negativas que en las Gram positivas. Esta diferencia en la capacidad fagocítica en ausencia de opsoninas entre las dos cepas bacterianas podría explicarse por las diferencias en la composición de la superficie de ambas cepas bacterianas. Cabe destacar que la estructura de la pared celular en las bacterias Gram positivas está compuesta principalmente de peptidoglicano con ácidos teicoicos, lipoproteínas y polisacáridos. Mientras que las bacterias Gram negativas tienen una pared celular más compleja, la capa de peptidoglicano es delgada y está rodeada de una membrana externa, que es una bicapa lipídica formada por LPS en la zona externa y por fosfolípidos en la zona interna. También hay un espacio periplásmico que contiene enzimas líticas y factores de virulencia (Aderem y Ulevitch, 2000). EI LPS activa la respuesta inmunitaria innata a través del receptor TLR4 y su correceptor MD-2 (Ohto et al., 2012; Tissières y Pugin, 2009), y hay evidencia de que las lipoproteínas tienen un papel importante en la activación de los receptores TLR2 (Fournier, 2013).

Estas diferencias en los mecanismos de señalización asociados a cada estímulo explican por qué el LPS, zymosán y partículas inertes de látex son capaces de inducir respuestas muy diferentes en las células inmunitarias estudiadas, y tener unas rutas de señalización distintas para generar las respuestas.

Sería interesante profundizar más en el mecanismo de reclutamiento y analizarlo con otras bacterias Gram negativas y positivas, o incluso con otros microorganismos intracelulares como Salmonella typhimurium o Mycobacterium tuberculosis. Este es uno de los objetivos que se plantea nuestro laboratorio como continuación de este trabajo. 
Los resultados presentados aquí permiten afirmar la implicación del complejo I en la modulación de la fagocitosis no opsónica de bacterias por los macrófagos. Hemos observado que la inhibición de la actividad del complejo I con rotenona, y con shRNA contra las subunidades NDUFS3 y NDFUS4, inducen todos ellos en macrófagos efectos similares a los encontrados cuando la proteína FASTK está ausente. Podemos considerar el complejo I como un sensor y efector en la regulación de la fagocitosis de bacterias, y esto podría ser el resultado de una adaptación evolutiva de los macrófagos para combatir la invasión bacteriana.

El aumento en la fagocitosis de bacterias en los macrófagos FASTK KO es un resultado de potencial importancia translacional, ya que ofrece una nueva diana para aplicar estrategias farmacológicas con el fin de aumentar la captación y la eliminación de bacterias, por ejemplo, en la sepsis. La sepsis es una respuesta inflamatoria sistémica inducida por una infección, que conduce a una disfunción orgánica grave y es causa de gran mortalidad. Es un problema de salud que afecta a millones de personas en todo el mundo cada año. Induce defectos en la inmunidad que causan inflamación prolongada, supresión inmunitaria (como la disminución en la producción de citoquinas y se reduce la fagocitosis, entre otras características), con susceptibilidad a las infecciones y la muerte. La neumonía es el origen más común de sepsis, seguido de las infecciones del tracto urinario y de las intraabdominales (Delano y Ward, 2016; Angus et al., 2013).

En la primera versión del manuscrito enviado a Journal of Immunology no se definió cuál de las etapas del proceso fagocítico estaba regulada por la proteína FASTK durante la fagocitosis: unión receptor-ligando, internalización de la partícula, fusión fagolisosomal o destrucción de las partículas o bacterias ingeridas. En este estudio, se observó un aumento en la fagocitosis a los 60 minutos después de la exposición de partículas fagocíticas en los macrófagos FASTK KO en comparación con los macrófagos WT. Se demostró que el número de bacterias E.coli y S.aureus (dos horas después de la infección) que sobrevivían era mayor en los macrófagos FASTK KO que en los controles WT. El comentario crítico más importante de los revisores de esa versión del artículo era identificar si la ausencia de FASTK conducía a un retraso en la fusión fagolisosomal. Hay que tener en cuenta que un aumento de la actividad bactericida a las dos horas en nuestro ensayo podría significar un retraso en la fusión fagolisosomal. Tras revisar la literatura (Blander y Medzhitov, 2004; Viegas et al., 2012; Maselli et al., 2002; Sokolovska et al., 2013; Wang et al., 2008; Santarino et al., 2017), decidimos llevar a cabo la fagocitosis en presencia de partículas no opsonizadas a tiempos cortos, 15 y 30 minutos. En primer lugar, los ensayos de fagocitosis no opsónica 
se han realizado reduciendo los tiempos de incubación con bacterias (E.coli, S.aureus), zymosán y partículas inertes de látex (beads) en los protocolos de fagocitosis y ensayos de protección con gentamicina utilizados. Los resultados obtenidos en la versión final del manuscrito (para el tiempo de incubación de 30 minutos, ver figura 1A, figura $\mathbf{3 A}$, figura 4B, figura 5C, panel inferior; y para el tiempo de incubación de 15 minutos, ver figura suplementaria $1 \mathrm{~B}$, figura suplementaria $3 \mathrm{C}$ y figura suplementaria $4 \mathrm{~A}$ en el Anexo II) muestran a los 15 y 30 minutos después de añadir las bacterias un aumento en la captación bacteriana en los macrófagos FASTK KO. En segundo lugar, se estudió la unión (binding) de las bacterias a los macrófagos durante la fagocitosis, para ello se incubaron los macrófagos FASTK KO y WT con bacterias no opsonizadas marcadas con FITC y sin antibiótico ni FBS, a $4^{\circ} \mathrm{C}$ durante 30 minutos y se cuantificó la adherencia de bacterias por citometría de flujo. No se observaron diferencias en la unión de las bacterias entre los macrófagos WT y los macrófagos FASTK KO. En tercer lugar, se empleó el ensayo de protección con gentamicina para estudiar la actividad bactericida (killing) a diferentes tiempos de incubación (0,15, 30, 45, 60, 90 y 120 minutos). Las bacterias no opsonizadas se expusieron a los macrófagos durante 15 minutos seguido de los diferentes tiempos de incubación con gentamicina especificados hasta las 2 horas. El tiempo 0 corresponde a 15 minutos después de añadir la gentamicina. En este experimento se plaquearon las diluciones seriadas de los lisados celulares en placas de LB agar y se contaron las bacterias (UFC) a las 24 horas de crecimiento a $37^{\circ} \mathrm{C}$. Se confirmó así que la actividad bactericida no estaba alterada en los macrófagos FASTK KO en ningún tiempo de la cinética, y se correlacionaban las UFC en los macrófagos FASTK KO con el aumento observado en la captación bacteriana. En el último tiempo de la cinética (120 minutos) los macrófagos FASTK KO y WT habían eliminado el $\sim 60 \%$ de E.coli ingerido y el $\sim 50 \%$ de S.aureus ingerido. En conjunto, estos datos demuestran que la fase de la fagocitosis que estaba aumentada en los macrófagos FASTK KO es la internalización de bacterias. Estos experimentos también se llevaron a cabo en los macrófagos WT y los macrófagos tratados con rotenona, mostrando una actividad bactericida normal a tiempo 120 minutos. Se observó el mismo fenotipo en las células RAW 264.7 silenciadas en las subunidades NDUFS3 y NDUFS4. Además, los experimentos de fagocitosis a tiempos cortos se llevaron a cabo en las células a las que se reintrodujo FASTK, y en las células pretratadas con el compuesto $\mathrm{C}$ (compound $\mathrm{C}$ ) (ver Figura 5C, Figura 6C, Figura suplementaria 4A del Anexo II).

También se analizó la fusión fagolisosomal con la bacteria E.coli que expresaba GFP. Los fagosomas contienen las bacterias fagocitadas que maduran en fagolisosomas. El compuesto LysoTracker marca selectivamente los endosomas tardíos 
y lisosomas, y colocaliza con la proteína LAMP. Se evaluó la maduración de los fagosomas que contenían E.coli-GFP por su capacidad de colocalizar con Lysotracker. Se realizó de forma similar al ensayo de protección con gentamicina, introduciendo el Lysotracker Red DND-99 (500 nM) durante los últimos cinco minutos de cada periodo de incubación para observar la colocalización de E.coli (verde) con el LysoTracker (rojo). Se demostró que no había un retraso en la fusión, ya que los macrófagos FASTK KO y WT muestran porcentajes similares de colocalización entre los dos marcadores verde y rojo. Se observó que alcanzaban $\sim 50 \%$ de colocalización en 120 minutos (ver Figura suplementaria 2B del Anexo II). Luego las cinéticas de la maduración de los fagosomas que contenían E.coli en los dos tipos de macrófagos eran similares y no estaban alteradas.

Los experimentos llevados a cabo muestran que la unión receptor-ligando (binding), la fusión fagolisosomal (phagolysosomal fusion) y la eliminación bacteriana (killing) están intactos en las células deficientes en FASTK o en las que se induce inhibición del $\mathrm{Cl}$ mitocondrial.

\section{El complejo I y el metabolismo mitocondrial en la inmunidad innata}

Los macrófagos murinos peritoneales tratados con rotenona y expuestos a las bacterias Gram negativas (E.coli), así como con las bacterias Gram positivas (S.aureus), mostraron una capacidad fagocítica aumentada. En consonancia con este hecho, la activación de los macrófagos con el componente de la pared celular de bacterias Gram negativas, el lipopolisacárido, a través del receptor TLR4 induce una reprogramación metabólica, que consiste en la disminución de la respiración mitocondrial (OXPHOS) y en el aumento de la glucólisis, mientras que la glutamina repone el ciclo del ácido tricarboxilico a través de la glutaminólisis (Tannahill et al., 2013; Lachmandas et al., 2016; Rodríguez-Prados et al., 2010; O’Neill y Pearce, 2016). Dependiendo del tipo de receptor TLR estimulado existen diferentes vías metabólicas en los monocitos. Cuando el complejo I se inhibe farmacológicamente hay una disminución en la producción de citoquinas y de la fagocitosis, y un aumento en la producción de oxígeno y en la actividad enzimática mitocondrial solo en los monocitos estimulados con P3C (lipopéptido que activa el heterodímero TLR1/TLR2), pero ésto no ocurre después de la estimulación con LPS (Lachmandas et al., 2016).

La mitocondria regula el flujo de electrones como adaptación de las señales inmunitarias innatas. El metabolismo mitocondrial y la ETC regulan la señalización, transcripción y epigenética en esta respuesta inmunitaria innata. La señalización de los receptores induce cambios en los flujos metabólicos y el balance redox (Sancho et al., 2017). 
En la fagocitosis, los macrófagos son dependientes de varias vías metabólicas, como la oxidación de ácidos grasos. El cambio del metabolismo que provoca el LPS de las bacterias Gram negativas está relacionado con el estudio de Garaude et al., que han identificado adaptaciones de la ETC como un punto metabólico-inmunológico que ajusta la respuesta inmunitaria innata a la infección de bacterias. Si bien confirman la disminución en el ensamblaje del complejo I que resulta en la disminución de la actividad de este complejo y en las adaptaciones metabólicas celulares tras el reconocimiento de bacterias Gram negativas vivas. Además, estos autores describen que el reconocimiento de bacterias Gram negativas a través del receptor TLR y vías dependientes del inflamasoma NLRP3 disminuyó transitoriamente la abundancia de los supercomplejos dentro de la mitocondria del macrófago. Este estudio muestra que la fagocitosis de bacterias vivas en los macrófagos, desestabiliza el ensamblaje del complejo I de la ETC reduciendo su actividad, pero aumentando la actividad del complejo II. Estos cambios dependen de la NADPH oxidasa del fagosoma (NOX) y la tirosina quinasa Fgr dependiente de la producción de ROS (Garaude et al., 2016), en consonancia con el estudio de Acín-Pérez et al. En este estudio se demuestra que la activación de la glicerol-3-fosfato deshidrogenasa y el complejo II, aumentan en la respuesta a bacterias vivas o al RNA bacteriano mediado por TLR. La actividad del CII produce ROS fagosomal, que activa la tirosina quinasa Fgr (Acín-Pérez et al., 2014).

El cambio metabólico con depresión de OXPHOS y aumento de la glucólisis aeróbica depende de la ruta fosfatidil inositol 3'-quinasa/Akt, ruta que es inhibida por la proteína quinasa activada por adenosina monofosfato (AMPK). Este cambio ha sido descrito en células dendríticas tras la activación de los receptores TLR2, TLR4 y TLR9 y es bloqueado por la citoquina antiinflamatoria IL-10 y AMPK (Krawczyk et al., 2010). Por lo tanto, las adaptaciones de la cadena respiratoria mitocondrial contribuyen a la defensa frente a bacterias, y ocurre después de la activación de los receptores inmunitarios innatos.

El perfil metabólico de los macrófagos durante la infección por ciertas bacterias puede deberse a una alteración en la organización de los complejos respiratorios mitocondriales. Aún hay pocos estudios sobre el impacto de la reprogramación metabólica y la importancia de ciertas disfunciones mitocondriales en la función de la respuesta inmunitaria.

Hay estudios que muestran los cambios metabólicos durante la fagocitosis, por ejemplo, la activación mediante LPS lleva a la acumulación de citrato en los macrófagos que puede ser metabolizado a ácido itacónico, ejerciendo éste efectos antibacterianos frente a varios patógenos, como Salmonella enterica Typhimurium o Legionella 
pneumophila (Michelucci et al., 2013; Naujoks et al., 2016). Las enzimas pueden formar grandes complejos, y proporcionan evidencia de la existencia de supercomplejos respiratorios mitocondriales, identificando el ensamblaje dinámico como un mecanismo a través del cual las células pueden adaptarse a la cadena de transporte de electrones. Se ha descrito una proteína de ratón (SCAFI) que modula el ensamblaje de los complejos respiratorios en supercomplejos (Lapuente-Brun et al., 2013). Se ha propuesto que el ensamblaje dinámico de los complejos respiratorios dentro de los supercomplejos, puede conferir ventajas funcionales para las células potenciando el flujo de electrones dentro de la cadena de transporte de electrones, y previniendo así la generación de ROS o estabilizando los complejos respiratorios individuales (Enríquez et al., 2016). Un cambio en el sustrato del ciclo de los ácidos tricarboxílicos modifica la relación $\mathrm{NADH} / \mathrm{FADH}$, que puede saturar la capacidad de oxidación de la coenzima $Q$ y por tanto inducir una transferencia de electrones reversa hacia el complejo I. Esto aumenta los superóxidos que oxidan las proteínas específicas del complejo I y por lo tanto conduce a un desensamblaje de este complejo (Guarás et al., 2016). Después del acoplamiento de los TLRs de superficie, la expresión de ROS dentro de la ETC aumenta y esto constituye una fuente de ROS desestabilizadores del complejo I (West et al., 2011a). Utilizando la metfomina como inhibidor del metabolismo mitocondrial se reduce la producción de interferón- $\gamma$, sugiriendo que esta inhibición podría ser una nueva estrategia terapéutica prometedora para ciertas enfermedades autoinmunes como por ejemplo el lupus eritematoso sistémico. Se ha descrito también una relación entre la glucólisis y el metabolismo oxidativo mitocondrial en las funciones inflamatorias en las células T CD4 ${ }^{+}$(Yin et al., 2015).

Todos estos datos señalan al complejo I como un regulador importante de la fagocitosis bacteriana mediada por los macrófagos. La disminución de la actividad del complejo I puede generar cambios en el metabolismo oxidativo, como el consumo de oxígeno, la glucólisis, los niveles de lactato, la relación entre NAD $/ \mathrm{NADH}$. Por este motivo, nuestro laboratorio planea llevar a cabo ensayos para conocer qué impacto tiene la inhibición del $\mathrm{Cl}$ mitocondrial en el perfil metabólico del macrófago, ya que no hay evidencia que relacione directamente la reprogramación metabólica de los macrófagos con un aumento en la fagocitosis no opsónica de bacterias. Se estudiarán las actividades de los complejos OXPHOS, el perfil bioenergético y los perfiles glucolíticos, como las tasas de consumo de oxígeno (OCR, Oxygen Consumption Rates) y las tasas de acidificación extracelular (ECAR, Extracellular Acidification Rates), en los macrófagos peritoneales murinos WT y FASTK KO, así como en las células RAW 264.7 silenciadas en las subunidades NDUFS3 y NDUFS4, incubándolas con bacterias (vivas 
y muertas): E.coli y S.aureus. Los resultados esperados serían un aumento en ECAR en los macrófagos FASTK KO y células RAW 264.7 silenciadas en NDUFS3 y NDUFS4, y una disminución en la actividad del complejo I y OCR. Podría haber un aumento en la actividad del complejo II al añadir bacterias Gram negativas durante la infección bacteriana según el estudio de Garaude et al., por los cambios descritos en la estabilidad de los supercomplejos (Garaude et al., 2016).

También se cuantificarán los niveles intracelulares de algunos metabolitos del ciclo de Krebs, como el succinato, itaconato y citrato, y de la expresión de enzimas glicolíticas como hexoquinasa 2 (HK2), fosfofructoquinasa-1 (PFK1) y lactato deshidrogenasa (LDHA). Los resultados esperados serán un incremento en algunos de los metabolitos involucrados en el aumento de la fagocitosis no opsónica de bacterias en los macrófagos FASTK KO, y células RAW 264.7 silenciadas en NDUFS3 y NDUFS4. Como se ha descrito anteriormente algunos de estos metabolitos tienen funciones en la señalización inflamatoria (Kelly et al., 2015; Mills et al., 2018). También sería interesante explorar el efecto de la inhibición de AMPK en el metabolismo de los macrófagos FASTK $\mathrm{KO}$ en presencia o no de bacterias.

\section{Mecanismos moleculares en la regulación de la fagocitosis}

\subsection{AMPK como vía de señalización de la fagocitosis}

Como mencionamos anteriormente, AMPK es una quinasa heterotrimérica compuesta por una subunidad catalítica $\alpha$ y dos subunidades reguladoras, $\beta$ y $\gamma$. Los vertebrados tienen varias isoformas de cada subunidad, codificado por diferentes genes. En humanos hay dos isoformas $\alpha$ ( $\alpha 1$ y $\alpha 2)$, dos $\beta$ ( $\beta 1$ y $\beta 2)$, y tres $\gamma(\gamma 1, \gamma 2$ y $\gamma 3$ ) (Herzig y Shaw, 2018). La subunidad $\alpha$ contiene un dominio quinasa y un residuo crítico, Thr172, cuya fosforilación activa AMPK. La quinasa AMPK se considera como una diana potencial para el tratamiento de enfermedades asociadas con un cambio metabólico. Esto incluye la diabetes, la obesidad y el hígado graso y también el cáncer, que está a menudo asociado a cambios en el metabolismo (Herzig y Shaw, 2018; Carling et al., 2017).

Con objeto de explicar el mecanismo de acción de la proteína FASTK en la regulación de la capacidad fagocítica de bacterias mediada por los macrófagos, en primer lugar, se estudió la fosforilación de AMPKa. Está descrito que las células sometidas a inhibición del complejo I dependían de glucosa y tenían una mayor fosforilación de AMPK $\alpha$, por lo que la disfunción del complejo I desencadena una 
respuesta metabólica y una adaptación que depende de la activación de AMPK (Distelmaier et al., 2015).

De acuerdo con esto, nos preguntamos si la fosforilación de AMPK $\alpha$ estaría afectada en los macrófagos de ratón deficientes en la proteína FASTK, debido a que mostraban una disminución en la actividad del complejo I. Después de llevar a cabo este experimento, se obtuvieron los resultados esperados, es decir, observamos que los macrófagos FASTK KO muestran un aumento en los niveles basales de la fosforilación de AMPK $\alpha$. Tras la estimulación con las bacterias el aumento de la fosforilación de AMPK $\alpha$ sólo es significativo en los macrófagos de tipo salvaje, mientras que en los macrófagos FASTK KO no se observó un aumento significativo en la fosforilación de AMPK $\alpha$. La activación de AMPK puede ser importante en la defensa del huésped a través del aumento en la captación (uptake) y en el aclaramiento de bacterias.

Nuestros datos han sido comparados con los obtenidos en estudios que han demostrado que la activación de AMPK tiene efectos antiinflamatorios y aumenta la capacidad fagocítica de neutrófilos o macrófagos para ingerir bacterias. En un estudio sobre el papel de AMPK en la fagocitosis se ha descrito que la ingestión de E.coli o de células apoptóticas por los macrófagos aumentan la actividad de AMPK (Bae et al., 2011). También está descrito que el tratamiento con AICAR, metformina o berberina puede activar AMPK y aumentar la capacidad para ingerir bacterias, mientras que el compuesto $C$ (compound $C$ ) inhibe la activación de AMPK en poblaciones celulares, incluyendo los macrófagos y neutrófilos (Bae et al., 2011; Zhao et al., 2008; Jeong et al., 2009). Estos datos se correlacionan con los resultados que hemos obtenido con el inhibidor de AMPK, al demostrar que los macrófagos FASTK KO y las células silenciadas en FASTK tratadas con el compuesto $\mathrm{C}$ revierten el fenotipo estudiado.

La activación de AMPK por AICAR o metformina aumenta también la eferocitosis (Bae et al., 2011). Otros estudios muestran que el mecanismo de acción de la metformina está involucrado en la activación de AMPK en los hepatocitos, induce estrés energético a través de la inhibición del complejo I en la mitocondria, y esto conduce a un cambio en la proporción ATP a AMP y la activación de AMPK (Zhou et al., 2001). Se ha descrito que bajas concentraciones de metformina activan AMPK por un aumento de la fosforilación de AMPK $\alpha$, suprimiendo la producción de glucosa en los hepatocitos. El mecanismo que subyace al aumento de la fosforilación de AMPK $\alpha$ y la activación mediante metformina es desconocido (Meng et al., 2014). El tratamiento en neutrófilos con metformina o AICAR mejoran la fagocitosis y la muerte bacteriana, incluyendo una mayor erradicación de bacterias en ratones con sepsis por peritonitis. AICAR aumentó 
la actividad de AMPK y la captación de células apoptóticas (Quan et al., 2015). No está determinado el mecanismo responsable que muestra la activación de AMPK en la regulación de la fagocitosis.

La vía de señalización de AMPK coordina el crecimiento celular, la autofagia y el metabolismo. AMPK se activa cuando los niveles de AMP y ADP aumentan en las células debido a una variedad de factores fisiológicos, como el estrés, inhibidores mitocondriales como las biguanidas, el resveratrol, y AICAR, entre otros (Mihaylova y Shaw, 2011). Jenkins et al. observan que tras inhibir el complejo I con R419 (N-(1-(4cyanobenzyl) piperidin-4-yl)-6-(4-(4-methoxybenzoyl) piperidine-1-carbonyl) nicotinamida; inhibidor del $\mathrm{Cl}$ ) en hepatocitos de ratón, hay una activación de AMPK (Jenkins et al., 2013). En otro estudio confirman que la rotenona induce fosforilación de AMPK a través de la supresión del complejo I mitocondrial, reduciendo la relación $\mathrm{NAD} / \mathrm{NADH}$ y el consumo de oxígeno, en hepatocitos. Otros inhibidores mitocondriales del complejo I, el amobarbital, y el silenciamiento de NDUFA13, subunidad del complejo I, tienen efectos similares (Hou et al., 2018).

La activación de AMPK disminuye la producción de citoquinas proinflamatorias, incluyendo TNF- $\alpha$, por el receptor TLR4 en neutrófilos y macrófagos (Zhao et al., 2008). Asimismo, estudios en un modelo de lesión pulmonar aguda en ratones inducido por LPS han demostrado que la activación de AMPK así como el aumento de especies reactivas de oxígeno tienen propiedades antiinflamatorias, disminuyendo la gravedad de la lesión pulmonar aguda (Zmijewski et al., 2009; Zmijewski et al., 2008). En el estudio de Mounier et al. se demostró que la deficiencia de AMPK $\alpha 1$ condujo a una disminución en la actividad fagocítica de los macrófagos, y a un bloqueo en la transición fenotípica de los macrófagos M1 a M2. En relación con esto, se descubrió que la AMPK fosforilada se asociaba solo con los macrófagos que llevaban a cabo la fagocitosis de miofibrillas necróticas en la regeneración muscular (Mounier et al., 2013). En la misma línea, el estudio de Carroll et al. proporciona evidencia de que AMPK $\alpha 1$ actúa como un regulador negativo de la función inflamatoria inducida por TLR, demostrando que los macrófagos y células dendríticas deficientes en AMPK $\alpha 1$ muestran una respuesta inflamatoria aumentada (Carroll et al., 2013).

Todos estos estudios demuestran que la inhibición del complejo I activa AMPK. El papel del complejo I es crítico, podría subrayar el equilibrio y la especificidad de las vías de señalización que regulan la fagocitosis de las bacterias y su relación con las mitocondrias en los macrófagos, ya que por un lado la disminución del $\mathrm{Cl}$ aumenta la fosforilación de AMPK $\alpha$ en la fagocitosis no opsónica de bacterias (García del Río et al., 
2018), y la inflamación (datos preliminares del estudio), y por otro lado, la activación de AMPK disminuye la inflamación y su subunidad $\alpha$ es necesaria para el establecimiento del patrón antiinflamatorio de los macrófagos M2 (Mounier et al., 2013). Es importante estudiar si las citoquinas están afectadas durante el aumento observado en la fagocitosis no opsónica en nuestro modelo.

\subsection{AMPK y la implicación del citoesqueleto en la fagocitosis}

La activación de AMPK resulta en una reorganización del citoesqueleto, incluyendo un aumento en la formación de redes de actina y microtúbulos durante la fagocitosis (Bae et al., 2011). Tras la adición a los cultivos celulares del compuesto C, un inhibidor de AMPK, o de citocalasina, se observa un bloqueo en el ensamblaje de actina y una inhibición de la fagocitosis (Bae et al., 2011; DeFife et al., 1999; Sulahin et al., 2008). Además, metformina y AICAR inducen polimerización de actina, y activan a AMPK. Esto demuestra que la activación farmacológica de AMPK aumenta la capacidad fagocítica, que en este caso se propuso que estaba relacionada con un aumento en la polimerización de actina y microtúbulos. Por lo que podría facilitar la erradicación bacteriana en sepsis y otras condiciones inflamatorias, mientras que la activación de AMPK no se observó en los macrófagos derivados de médula ósea expuestos a células apoptóticas (Park et al., 2013). Lo que plantea la posibilidad de que haya efectos diferenciales, en la digestión de la partícula ingerida, en función del estado de activación de los fagocitos.

Un sustrato directo de AMPK, CLIP-170, está involucrado en la dinámica de los microtúbulos durante la fagocitosis (Binker et al., 2007). Se ha demostrado que AMPK regula la dinámica de los microtúbulos a través de la fosforilación de CLIP-170. Además, se ha estudiado que el inhibidor de AMPK, compuesto $C$, reduce los niveles de fosforilación de CLIP-170, mientras que el activador de AMPK, AICAR, no afecta a la fosforilación de CLIP-170 (Nakano et al., 2010). Es posible que AMPK pueda afectar a otras proteínas del citoesqueleto asociadas con la fagocitosis como Rac1 y las proteínas efectoras de Rac: PAKs ( $p 21$-activated kinases) y WAVE (WASp family verprolinhomologous protein), ya que hay evidencias de que la adición de AICAR en los macrófagos aumenta la fosforilación de PAK1/2 y WAVE2 (Bae et al., 2011). Uno de los objetivos para la continuación de este trabajo de investigación es explorar los niveles de fosforilación de PAK1/2 y WAVE durante la fagocitosis no opsónica en los macrófagos FASTK KO.

En el estudio Quan et al. también observan un aumento de la fagocitosis de células apoptóticas mediado por macrófagos utilizando AICAR a través de la activación 
de la vía p38 MAPK, sugiriendo que es independiente de AMPK y está asociado con la reorganización del citoesqueleto (Quan et al., 2015). En consonancia con estos estudios discutidos, nuestra investigación profundizará en el estudio y la cuantificación del contenido de F-actina durante la fagocitosis de bacterias, ya que se ha observado un aumento en el contenido de la proteína F-actina durante la fagocitosis de E.coli en los macrófagos FASTK KO. Este hecho pone de manifiesto la necesidad de llevar a cabo otras aproximaciones experimentales para que podamos revelar los mecanismos moleculares discutidos en detalle.

AMPK es sensible al nivel celular de las especies reactivas de oxígeno. En muchos casos el estrés oxidativo resulta en la supresión intracelular de ATP. Sin embargo, estudios recientes han revelado que ROS puede estimular la actividad de AMPK incluso sin una disminución del ATP celular (Zmijewski et al., 2008; Quintero et al., 2006; Zmijewski et al., 2010). La inhibición del complejo I con rotenona o metformina se asocia con niveles intracelulares aumentados de superóxido y peróxido de hidrógeno,

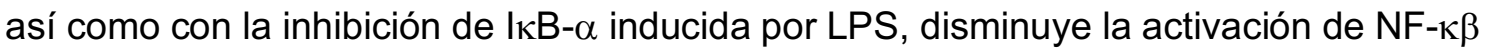
y la producción de citoquinas proinflamatorias en los neutrófilos estimulados con LPS. También se demostró que la rotenona y metformina disminuyen la gravedad en un modelo de lesión pulmonar en ratón. Aunque generalmente se cree que la mayor formación de las especies reactivas de oxígeno se asocia con situaciones fisiopatológicas que conducen a la lesión celular y la disfunción orgánica, se han demostrado efectos beneficiosos de ROS en la modulación de la inflamación, incluida la lesión pulmonar aguda asociada a LPS (Zmijewski et al., 2008).

\subsection{El aumento de ROS mitocondrial en la fagocitosis}

Como ya hemos mencionado, los fagocitos son células especializadas del sistema inmunitario que fagocitan microorganismos patógenos y los destruyen en fagosomas. El proceso de eliminación eficiente de bacterias depende principalmente de la producción de especies reactivas de oxígeno, dado que los ROS son tóxicos para los microorganismos y además actúan como segundos mensajeros activando otros mecanismos microbicidas. Las especies reactivas de oxígeno están implicadas en enfermedades inflamatorias crónicas incluyendo la artritis reumatoide y la esclerosis múltiple, entre otras. Se generan en la membrana del fagosoma a través de NOX como un subproducto de la cadena de transporte de electrones mitocondrial (Lambeth, 2004; Pavia y Boza, 2014), y las NADPH oxidasas son críticas en la defensa del huésped al producir superóxido. Cabe destacar que la disfunción mitocondrial está asociada con un aumento en la producción de ROS (Murphy et al., 2013; Koopman et al., 2005). Los 
mitoROS contribuyen de forma directa en la producción de citoquinas proinflamatorias y la respuesta inmunitaria innata, considerándose importantes en la actividad bactericida de los macrófagos, y funcionan como intermediarios de señalización para facilitar la adaptación de la célula al estrés (Sena y Chandel., 2012).

Así pues, nos planteamos si la actividad microbicida estaría afectada en los ratones deficientes en la proteína FASTK. A través de la sonda sensible a ROS, MitoSOX, para medir el superóxido (mitoROS) por citometría de flujo, se ha identificado una señalización de mitoROS involucrada en la defensa del huésped demostrando que los macrófagos deficientes de FASTK durante la fagocitosis producen un aumento en la producción de ROS mitocondriales en comparación con las células WT. Mientras que la cantidad basal de los mitoROS era prácticamente la misma. En cambio, los ROS intracelulares, medidos a través de quimioluminiscencia no mostraron cambios en los macrófagos murinos deficientes de la proteína, ni en los macrófagos tratados con rotenona en comparación con los de tipo salvaje, durante la fagocitosis de bacterias y zymosán.

Por lo tanto, el mecanismo por el cual ROS elimina a los patógenos sigue siendo un tema de debate y está aún por definir. Desde el punto de vista de los fagocitos, es crítico producir cantidades suficientes de ROS para eliminar al patógeno antes de que pueda dar una respuesta eficaz al estrés oxidativo. En cambio, la producción de ROS insuficiente no sólo no elimina a los patógenos, también induce una respuesta de estrés que permite al patógeno resistir a mayores concentraciones de ROS. Por lo tanto, en determinadas circunstancias, los niveles bajos de ROS podrían provocar más daño que beneficio para el huésped (Dupré-Crochet et al., 2013).

Otros estudios han demostrado que la producción de mitoROS es esencial para múltiples vías iniciadas por receptores TLR. La activación de los receptores TLR asociados a la membrana de macrófagos (TLR1, TLR2 y TLR4) en respuesta a bacterias mediante la señalización del complejo I mitocondrial, está mediado por la asociación de TRAF6 con ECSIT. La interacción entre las dos moléculas conduce a una ubiquitinación de ECSIT, resultando en el aumento en la producción de mitoROS. Por lo que se demuestra una comunicación directa entre los receptores TLR de macrófagos y la mitocondria. Sin embargo, esta señalización de la mitocondria al fagosoma del macrófago por la cual ECSIT controla la generación de mitoROS permanece sin definir. Los macrófagos de ratón que carecen de ECSIT o TRAF6 muestran niveles disminuidos de ROS y la capacidad bactericida intracelular está disminuida. Además, la reducción de los niveles de mitoROS de los macrófagos de ratón da como resultado una 
eliminación bacteriana defectuosa, lo que confirma el papel de los mitoROS en la actividad bactericida (West et al., 2011a).

Los resultados obtenidos sobre la producción de mitoROS podrían interpretarse que son causados como consecuencia de la disminución de uno de los complejos, el complejo I mitocondrial, puesto que observamos un aumento en los mitoROS tras la infección con bacterias en los macrófagos FASTK KO en comparación con los macrófagos WT. Este dato se correlaciona con el estudio de West et al. (West et al., 2011a) que demuestran la liberación de mitoROS en el fagosoma como consecuencia del tráfico mitocondrial para mejorar el aclaramiento de bacterias intracelulares.

En este contexto la activación de la inmunidad innata de los fagocitos a través de la señalización TLR en respuesta a las bacterias, conduce a una activación de las quinasas Mst1 y Mst2 que se requiere para la producción óptima de ROS y la actividad bactericida de los fagocitos, por la activación de la GTPasa Rac, y a través del tráfico mitocondrial y la asociación de TRAF6 con ECSIT (Geng et al., 2015). Por tanto, la señalización del eje TLR-Mst1-Mst2-Rac es crítica para una función efectiva fagosomamitocondria y la inducción de mitoROS (Geng et al., 2015). En esta línea, se ha estudiado la regulación de la vía TLR/mitoROS en las células de pacientes con síndrome periódico asociado a defectos del receptor del factor de necrosis tumoral (TRAPS), trastorno autoinflamatorio autosómico dominante que se caracteriza por fiebres recurrentes, dolor abdominal, erupción migratoria, mialgia y artralgia. Se ha observado que las células de estos pacientes tienen mayor capacidad de respuesta a LPS debido al aumento de la producción de mitoROS. Una nueva estrategia para disminuir los síntomas de este trastorno autoinflamatorio es bloquear la producción de ROS mitocondriales (Bulua et al., 2011). Opuesto a estos datos, nos encontramos que la infección intracelular de Brucella abortus en células HeLa o macrófagos peritoneales, conduce a una activación de AMPK que inhibe la producción de especies reactivas de oxígeno en las células al suprimir la NADPH oxidasa, lo que contribuye a la supervivencia del patógeno bacteriano (Liu et al., 2016). Los macrófagos y neutrófilos de ratones deficientes en la proteína adaptadora MyD88 se ven afectados en su capacidad para destruir bacterias. Esto se debe a una función alterada del complejo NADPH oxidasa que conlleva a la producción reducida de ROS (Laroux et al., 2005). Esto podría indicar una relación entre las moléculas adaptadoras que intervienen en el reconocimiento del microorganismo y la producción de mitoROS.

NOX2 es una isoforma de la NADPH oxidasa, cuya subunidad catalítica es gp91phox (Bedard y Krause, 2007). Se ha demostrado que los macrófagos que carecen 
de gp91phox, producen niveles significativamente más bajos de IL-6. Esta pérdida está relacionada con la incapacidad de los macrófagos para producir ROS, mostrando una relación directa entre la producción de ROS mediada por NOX2 y la producción de citoquinas inflamatorias (Franchini et al., 2013).

Se ha descrito que los macrófagos deficientes en Ucp2, miembro de la familia de proteínas localizadas en la membrana mitocondrial interna que pueden desacoplar el gradiente electroquímico de la generación de ATP, generan más ROS en respuesta a Toxoplasma gondii regulando la respuesta inmunitaria frente al parásito y mejorando la capacidad bactericida (Arsenijevic et al., 2000). En el estudio de Rousset et al. observan un fenotipo similar: los ratones deficientes en Ucp2 eran más resistentes a Listeria monocytogenes con la producción de niveles altos de ROS (Rousset et al., 2006). La pérdida de Ucp2 dio como resultado un aumento en el potencial de membrana mitocondrial que afectó de forma negativa a la capacidad fagocítica. Los ratones deficientes en Ucp2 mostraron defectos in vivo en la eliminación de células apoptóticas en el timo y los testículos. Además, los fagocitos que engloban las células apoptóticas, pero no las partículas sintéticas, tienen una mayor tasa de oxidación de ácidos grasos (Park et al., 2011). Otro estudio investiga que los macrófagos deficientes en Ucp2 producen más mitoROS en condiciones basales que las células normales control, mientras que los macrófagos que tienen Ucp2 estimulados con LPS durante una hora aumentan la producción de mitoROS a diferencia de los macrófagos deficientes en Ucp2 estimulados con LPS que no modifican la generación de mitoROS. Esto indica que la ausencia de esta proteína en la célula induce la producción de mitoROS (Emre et al., 2007).

Los defectos mitocondriales están implicados en una variedad de problemas clínicos. Recientemente se ha informado que algunas proteínas mitocondriales son esenciales para la inmunidad innata, pero la función de la cadena respiratoria mitocondrial en la inmunidad innata es en gran parte desconocida. En el estudio de Chen et al. estudian una proteína de la subunidad del complejo I de la cadena respiratoria mitocondrial, GRIM-19 (gene associated with retinoid-IFN-induced mortality19), encontrando que los ratones heterocigotos GRIM-19+/ son propensos a la infección espontánea del tracto urinario, principalmente por Staphylococcus saprophyticus. Demuestran que los macrófagos derivados de estos ratones tienen una actividad reducida del complejo I mitocondrial, un aumento en los niveles de ROS, una disminución en la capacidad de eliminar bacterias y la producción de citoquinas proinflamatorias (como IL-1, IL-12, IL-6, IFN- $\gamma$ ). Inhibidores mitocondriales como la rotenona y la oligomicina, reducen la producción de estas citoquinas, y concluyen que 
la cadena respiratoria mitocondrial tiene un papel importante en la defensa contra las bacterias (Chen et al., 2012). La rotenona es un inhibidor efectivo de la cadena de transporte de electrones, aunque se ha demostrado que aumenta y disminuye la producción de ROS mitocondrial en una variedad de tipos celulares ( $\mathrm{Li}$ et al., 2003; Thompson et al., 2007). La rotenona fue capaz de inducir la producción mitocondrial de ROS en las células HL-60 (Human promyelocytic leukemia cells), sugiriendo que es capaz de inducir apoptosis a través de la producción mitocondrial de especies reactivas de oxígeno ( $\mathrm{Li}$ et al., 2003). La rotenona aumenta la producción de ROS en presencia de una concentración elevada de NADH. Sin embargo, en otro estudio se ha demostrado que el inhibidor metformina disminuye la producción de ROS relacionado con el flujo reverso pero no aumenta la producción de ROS relacionado con el flujo normal en presencia de glutamato-malato. Esta inhibición con metformina no afecta a la producción de ROS (Batandier et al., 2006).

Hay algunos estudios que relacionan los mitoROS con la activación de AMPK y el metabolismo, por ejemplo, se ha demostrado que mitoROS es un activador fisiológico de AMPK y que AMPK se une a mitoROS regulando la homeostasis y el balance metabólico celular (Rabinovitch et al., 2017). Hay autores que han propuesto que el peroxinitrito activa AMPK sin modificar el ratio ATP/AMP (An et al., 2007). De forma similar, otros autores observan que la inhibición del complejo I con rotenona, así como con metformina, conduce a la generación de radicales $\mathrm{O}_{2}^{-}$, involucrados en la activación de AMPK en células endoteliales aórticas bovinas vía ONOOO-, oxidante formado por óxido nítrico (NO) y aniones superóxido $\left(\mathrm{O}_{2}{ }^{-}\right)$(Zou et al., 2004). En el estudio de Mackenzie et al., observaron que la producción de ROS mitocondriales en el endotelio de pacientes con enfermedad coronaria y diabetes tipo 2 aumentaba la activación de AMPK, demostrando el papel de la quinasa en la defensa contra el estrés oxidativo (Mackenzie et al., 2013). Además, la disfunción mitocondrial inducida por el silenciamiento de la subunidad del complejo I NDUFS3, en células de riñón embrionario humano (HEK-293T), aumenta la glucólisis aeróbica regulada por el desequilibrio de ROS (Suhane et al., 2013).

Los metabolitos mitocondriales contribuyen a las funciones bactericidas del macrófago. Algunos metabolitos mitocondriales y el uso de inhibidores del complejo I y complejo II pueden modular la producción de citoquinas. Por ejemplo, la inhibición del complejo II aumenta la producción de IL-1RA y de IL-10 que promueven la respuesta antiinflamatoria previniendo la generación de mitoROS y la oxidación del succinato. El succinato conduce al aumento de la actividad del Cll que promueve la producción de 
mitoROS para estabilizar el factor de transcripción HIF-1 $\alpha$, promoviendo la expresión de la citoquina proinflamatoria IL-1 $\beta$ (Mills y O’Neill, 2016; Tannahill et al., 2013). En otros estudios se ha demostrado que los macrófagos activados por LPS inducen la producción de ROS, mientras que al utilizar inhibidores mitocondriales como la rotenona y la metformina disminuye la producción de mitoROS, reduciendo la producción de IL-1 $\beta$ y aumentando la producción de IL-10 (Kelly et al., 2015). Esto está respaldado por evidencias que demuestran que la deleción de la subunidad NDUFS4 del complejo I promueve un fenotipo de macrófago proinflamatorio (M1), lo que sugiere que la actividad del complejo I amortigua la activación de los macrófagos. La respuesta de los macrófagos a bacterias se caracteriza por un ensamblaje del complejo I reducido en los supercomplejos y una disminución de la actividad de este complejo. Curiosamente, la deleción de TLR2/4 en ratones deficientes en NDUFS4 atenuó el fenotipo inflamatorio (Jin et al., 2014).

Además, los metabolitos como el fumarato o itaconato y mitoROS muestran un efecto directo microbicida (Garaude et al., 2016; West et al., 2011b). El succinato también contribuye a un aumento en el transporte de electrones reverso y la producción de ROS desde el $\mathrm{Cl}$ (Chouchani et al., 2014). Del mismo modo, la succinato deshidrogenasa (SDH) metaboliza el succinato a fumarato en el ciclo TCA, y el fumarato inhibe las desmetilasas de histonas KDM5 (Arts et al., 2016). En este proceso, el complejo II acepta los electrones del $\mathrm{FADH}_{2}$, y al portar electrones impulsa la modulación de la señalización de ROS (Mills y O’Neill, 2016). Estos estudios establecen cómo los ROS conducen a la expresión de citoquinas proinflamatorias que caracterizan a los macrófagos M1, pero el mecanismo por el cual el succinato inhibe la expresión de genes antiinflamatorios es una cuestión abierta.

En cualquier caso, los datos nos sugieren que los mitoROS contribuyen a la actividad bactericida en macrófagos, aunque el mecanismo que relaciona la señalización inmunitaria innata con la mitocondria durante la generación de mitoROS no está claro. Este hecho hace reflexionar si las especies reactivas de oxígeno aumentan o disminuyen la activación de AMPK durante la fagocitosis, ya que hay controversia y es una vía de señalización aún por investigar en detalle.

\subsection{Mecanismo molecular de acción propuesto}

Hasta donde conocemos, este estudio es el primero en describir el papel de FASTK y el complejo I en la modulación de la fagocitosis no opsónica de bacterias por los macrófagos, ya que la función de FASTK en la fagocitosis no opsónica se debe a una deficiencia específica del complejo I de la cadena respiratoria. 
Este estudio proporcionará información molecular que ayudará en el diseño de agentes terapéuticos antiinfecciosos. Este trabajo ha identificado que la molécula FASTK activa AMPK a través del complejo I, evidenciando el mecanismo de activación de AMPK y su relación con las especies reactivas de oxígeno mitocondriales. En la Figura 41 se propone un modelo en función de los datos presentados, aunque se requieren estudios más detallados, a lo que se dedica actualmente nuestro laboratorio. Estudios adicionales de los mecanismos que subyacen a la fagocitosis contribuirían enormemente a nuestra comprensión de cómo el sistema inmunitario innato resuelve la infección bacteriana y también sentaría las bases para el desarrollo de estrategias terapéuticas que mejoren la captación y la eliminación de bacterias en las infecciones incipientes, antes del inicio de la respuesta inflamatoria o en infecciones en sitios anatómicos con un número limitado de opsoninas. Esto es importante en pacientes que tienen un riesgo mayor de aspirar las secreciones orofaríngeas, por ejemplo, y desarrollar neumonías.

Se requieren estudios más detallados y específicos para poder caracterizar de manera clara los efectos de la rotenona y el silenciamiento de las subunidades del complejo I, NDUFS3 y NDUFS4, en la fagocitosis no opsónica en los macrófagos. Además, es necesario trasladarlo a modelos in vivo, pero en función de los datos presentados podemos proponer un modelo que se esquematiza en la figura 41B. 


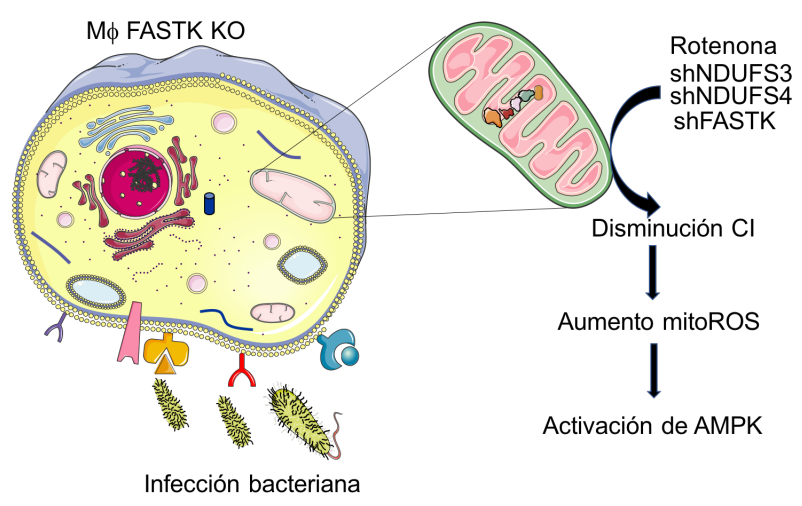

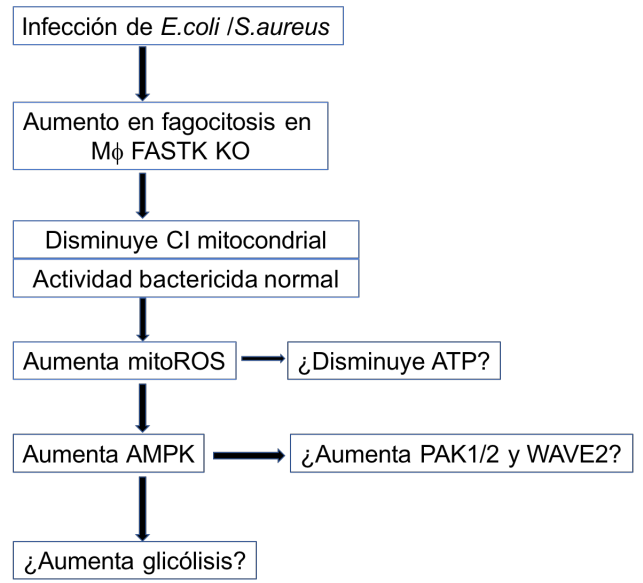

Figura 41. Posible mecanismo de acción propuesto para la fagocitosis no opsónica de bacterias. A. Se ha evidenciado que los niveles de mitoROS aumentan y se fosforila la proteína AMPK: en los macrófagos FASTK KO, a través de la disminución de la actividad del complejo l; en los macrófagos tratados con el inhibidor del complejo I, rotenona; y en los macrófagos silenciados en las subunidades del complejo I, NDUFS3 y NDUFS4. B. En los macrófagos FASTK KO durante la exposición de las bacterias E.coli y S.aureus no opsonizadas, aumenta la fagocitosis no opsónica, disminuye la actividad del complejo I (Cl) mitocondrial y la actividad bactericida no está alterada. Este aumento induce un aumento en los mitoROS y la activación de AMPK. Al mismo tiempo, está aún por estudiar si disminuye el ATP celular probablemente a través de la inhibición de la respiración mitocondrial. Es posible que la glucólisis esté aumentada ya que se ha observado una disminución en el $\mathrm{Cl}$ y posiblemente en la actividad OXPHOS (OCR disminuida y ECAR aumentada). Probablemente PAK1/2 y WAVE2 estén fosforiladas, aumentando la polimerización de actina durante la fagocitosis no opsónica.

Se propone que AMPK es activada por los mitoROS. Se observa un aumento de la fagocitosis no opsónica de bacterias en los macrófagos FASTK KO y una hiperfosforilación ( $\mathrm{y}$ por tanto una activación) de AMPK, así como el aumento de mitoROS. Así en nuestro caso, en este trabajo, se ha intentado esclarecer la posible vía de señalización en la fagocitosis no opsónica de bacterias. Independientemente de los niveles de mitoROS, es posible que la activación de AMPK se deba además a otra señal mediada por el complejo y/o las partículas fagocitadas a las que se exponen los macrófagos, como el aumento de AMP celular y que la glucólisis compense la disminución de ATP u otros tipos de ROS. 

CONCLUSIONES 



\section{CONCLUSIONES}

A partir de los resultados contenidos en el presente trabajo de investigación se extraen las siguientes conclusiones:

1. En ausencia de la proteína FASTK se observa una disminución de la actividad del complejo I mitocondrial, y un incremento en la fagocitosis no opsónica de bacterias (E.coli y S.aureus) en los macrófagos murinos primarios y en la línea celular murina RAW 264.7.

2. La ausencia de FASTK no altera sin embargo la fagocitosis de partículas de zymosán o de partículas inertes de látex, demostrando que el fenotipo es específico de la fagocitosis de bacterias.

3. La reexpresión de mitoFASTK en los macrófagos previamente silenciados en FASTK, restablece a la normalidad su función fagocítica de las bacterias mencionadas. Esto sugiere que la isoforma mitocondrial de FASTK funciona como un regulador negativo de la fagocitosis no opsónica en macrófagos.

4. La rotenona, inhibidor del complejo I mitocondrial, aumenta la capacidad fagocítica de los macrófagos de las bacterias E.coli y S.aureus, sin alterar su capacidad bactericida.

5. También se observa un aumento de la fagocitosis no opsónica de las mismas bacterias tras el silenciamiento mediante shRNA de las subunidades del complejo I, NDUFS3 y NDUFS4.

6. La ausencia de FASTK se acompaña de un aumento en los niveles basales de la fosforilación de la enzima AMPKa.

7. El tratamiento con el compuesto $C$, un inhibidor de la enzima AMPK, revierte el fenotipo fagocítico inducido por la ausencia de FASTK en los macrófagos primarios murinos y en la línea celular de macrófagos RAW 264.7.

8. Los macrófagos FASTK KO expuestos a bacterias muestran un aumento en la generación de las especies reactivas de oxígeno mitocondriales.

Es decir, los datos presentados en este trabajo demuestran que la disminución de la actividad del complejo I, sea por la ausencia de la proteina FASTK, o por la inhibición del complejo I mediante métodos genéticos o químicos, se traduce en un aumento de la fagocitosis no opsónica de bacterias; que se acompaña de la hiperfosforilación de la enzima AMPKa, y el aumento de la generación de las especies reactivas de oxígeno en la mitocondria. 

BIBLIOGRAFÍA 



\section{BIBLIOGRAFÍA}

Acín-Pérez R, Bayona-Bafaluy MP, Fernández-Silva P, Moreno-Loshuertos R, PérezMartos, Bruno C, Moraes CT, Enríquez JA. Respiratory complex III is required to maintain complex I in mammalian mitocondria. Mol Cell. 2004;13(6):805-15.

Acín-Pérez R, Carrascoso I, Baixauli F, Roche-Molina M, Latorre-Pellicer A, FernándezSilva P, Mittelbrunn M, Sanchez-Madrid F, Pérez-Martos A, Lowell CA, Manfredi G, Enríquez JA. ROS-triggered phosphorylation of complex II by Fgr kinase regulates celular adaptation to fuel use. Cell Metab. 2014;19(6):1020-33.

Aderem A, Ulevitch RJ. Toll-like receptors in the induction of the innate immune response. Nature. 2000;406(6797):782-7.

Akira S, Uematsu S, Takeuchi O. Pathogen recognition and innate immunity. Cell 2006;124:783-801.

An Z, Wang H, Song P, Zhang M, Geng X, Zou MH. Nicotine-induced activation of AMPactivated protein kinase inhibits fatty acid synthase in 3T3L1 adipocytes: a role for oxidant stress. J Biol Chem. 2007;282(37):26793-801.

Andrews B, Carroll J, Ding S, Fearnlwy IM, Walker JE. Assembly factors for the membrane arm of human complex I. Proc Natl Acad Sci U S A. 2013;110(47):18934-9.

Angus DC, van der Poll T. Severe sepsis and septic shock. $\mathrm{N}$ Engl J Med. 2013;369(9):840-51.

Anneda A, Rial E, González-Barroso MM. Metformin induces oxidative stress in white adipocytes and raises uncoupling protein 2 levels. J Endocrinol. 2008;199(1):3340.

Antonicka H, Choquet K, Lin ZY, Gingras AC, Kleinman CL, Shoubridge EA. A pseudouridine synthase module is essential for mitocondrial protein synthesis and cell viability. EMBO Rep. 2017;18(1):28-38.

Antonicka H, Sasarman F, Nishimura T, Paupe V, Shoubridge EA. The mitochondrial RNA-binding protein GRSF1 localizes to RNA granules and is required for posttranscriptional mitochondrial gene expression. Cell Metab. 2013;17(3):386-98.

Antonicka H, Shoubridge EA. Mitochondrial RNA granules are center for posttranscriptional RNA processing and ribosome biogenesis. Cell Rep. 2015;S2211-1247(15)00055-8.

Arango Duque G, Descoteaux A. Macrophage cytokines: involvement in immunity and infectious diseases. Front Immunol. 2014;5:491.

Areschoug T,Gordon S. Scavenger receptors: role in innate immunity and microbial pathogenesis. Cell Microbiol. 2009;11(8)1160-9.

Arsenijevic D, Onuma H, Pecqueur C, Raimbault S, Manning BS, Miroux B, Couplan E, Alves-Guerra MC, Goubern M, Surwit R, Bouillaud F, Richard D, Collins S, Ricquier D. Disruption of the uncoupling protein-2 gene in mice reveals a role in immunity and reactive oxygen species production. Nat Genet. 2000;26(4):435-9. 
Arts RJ, Novakovic B, Ter Horst R, Carvalho A, Bekkering S, Lachmandas E, Rodrigues F, Silvestre R, Cheng SC, Wang SY, Habibi E, Gonçalves LG, Mesquita I, Cunha C, van Laarhoven A, van de Veerdonk FL, Williams DL, van der Meer JW, Logie C, O'Neill LA, Dinarello CA, Riksen NP, van Crevel R, Clish C, Notebaart RA, Joosten LA, Stunnenberg HG, Xavier RK, Netea MG. Glutaminolysis and fumarate accumulation integrate immunometabolism and epigenetic programs in trained immunity. Cell Metab. 2016;24(6):807-819.

Bae HB, Zmijewski JW, Deshane JS, Tadie JM, Chaplin DD, Takashima S, Abraham E. AMP-activated protein kinase enhances the phagocytic ability of macrophages and neutrophils. FASEB J. 2011;25(12):4358-68.

Barkhausen T, Tschernig T, Rosenstiel P, van Griensven M, Vonberg RP, Dorsch M, et al. Selective blockade of interleukin- 6 trans-signaling improves survival in a murine polymicrobial sepsis model. Crit Care Med (2011) 39(6):1407-13.

Batandier C, Guigas B, Detaille D, El-Mir MY, Fontaine E, Rigoulet M, Leverve XM. The ROS production induced by a reverse-electron flux at respiratory-chain complex 1 is hampered by metformin. J Bioenerg Biomembr. 2006;38(1):33-42.

Bauer A, Kleeff J, Bier M, Wirtz M, Kayed H, Esposito I, Korc M, Hafner M, Hoheisel JD, Friess $\mathrm{H}$. Identification of malignancy factors by analyzing cystic tumors of the pancreas. Pancreatology. 2009;9(1-2):34-44.

Bedard K, Krause KH. The NOX family of ROS-generating NADPH oxidases: physiology and pathophysiology. Physiol Rev. 2007;87(1):245-313.

Ben-Sasson SZ, Hu-Li J, Quiel J, Cauchetaux S, Ratner M, Shapira I, et al. IL-1 acts directly on CD4 $T$ cells to enhance their antigen-driven expansion and differentiation. Proc Natl Acad Sci U S A (2009) 106(17):7119-24.

Benit P, Slama A, Cartault F, Giurgea I, Chretien D, Lebon S, Marsac C, Munnich A, Rötig A, Rustin P. Mutant NDUFS3 subunit of mitochondrial complex I causes Leigh syndrome. J Med Genet. 2004;41(1):14-7.

Beutler BA. The role of tumor necrosis factor in health and disease. J Rheumatol Suppl (1999) 57:16-21.

Binker MG, Zhao DY, Pang SJ, Harrison RE. Cytoplasmic linker protein-170 enhances spreading and phagocytosis in activated macrophages by stabilizing microtubules. J Immunol. 2007;179(6):3780-91.

Blander JM, Medzhitov R. Regulation of phagosome maturation by signals from toll-like receptors. Science. 2004;304(5673):1014-8.

Blaza JN, Vinothkumar KR, Hirst J. Structure of the deactive state of mammalian respiratory complex I. Structure. 2018;26(2):312-319.e3.

Bleier L, Dröse S. Superoxide generation by complex III: from mechanistic rationales to functional consequences. Biochim Biophys Acta. 2013; 1827(11-12):1320-31.

Boehm E, Zaganelli S, Maundrell K, Jourdain AA, Thore S, Martinou JC. FASTKD1 and FASTKD4 have opposite effects on expression of specific mitochondrial RNAs, depending upon their endonuclease-like RAP domain. Nucleic Acids Res. 2017;45(19):6135-6146. 
Boehm E, Zornoza M, Jourdain AA, Delmiro Magdalena A, García-Consuegra I, Torres Merino R, Orduña A, Martín MA, Martinou JC, De la Fuente MA, Simarro M. Role of FAST Kinase domains 3 (FASTKD3) in post-transcriptional regulation of mitochondrial gene expression. J Biol Chem. 2016;291(50):25877:25887.

Bonawitz ND, Clayton DA, Shadel GS. Initiation and beyond: multiple functions of the human mitochondrial transcription machinery. Mol Cell. 2006;24(6):813-25.

Bonomi S, Gallo S, Catillo M, Pignataro D, Biamonti G, Ghigna C. Oncogenic alternative splicing switches: role in cancer progression and prospects for therapy. Int J Cell Biol. 2013;2013:962038.

Brown GD. Dectin-1: a signalling non-TLR pattern-recognition receptor. Nat Rev Immunol. 2006;6(1):33-43.

Brungs S, Kolanus W, Hemmersbach R. Syk phosphorylation - a gravisensitive step in macrophage signaling. Cell Commun Signal. 2015;13:9.

Brutsche MH, Brutsche IC, Wood P, Brass A, Morrison N, Rattay M, Mogulkoc N, Simler N, Craven M, Custovic A, Egan JJ, Woodcock A. Apoptosis signals in atopy and asthma measured with cDNA arrays. Clon Exp Immunol. 2001;123(2):181-7.

Brzezniak LK, Bijate M, Szczesny RJ, Stepien PP. Involvement of human ELAC2 gene product in 3' end processing of mitochondrial tRNAs. RNA Biol. 2011;8(4):616-26.

Bulua AC, Simon A, Maddipati R, Pelletier M, Park H, Kim KY, Sack MN, Kastner DL, Siegel RM. Mitochondrial reactive oxygen species promote production of proinflammatory cytokines and are elevated in TNFR1-associated periodic syndrome (TRAPS). J Exp Med. 2011:208(3):519-33.

Canton J. Phagosome maturation in polarized macrophages. J Leukoc Biol. 2014;96(5):729-38.

Carling D. AMPK signalling in health and disease. Curr Opin Cell Biol. 2017;45:31-37.

Carmi Y, Voronov E, Dotan S, Lahat N, Rahat MA, Fogel M, et al. The role of macrophage-derived $\mathrm{IL}-1$ in induction and maintenance of angiogenesis. $\mathrm{J}$ Immunol (2009) 183(7):4705-14.

Carroll KC, Viollet B, Suttles J. AMPK $\alpha 1$ deficiency amplifies proinflammatory myeloid APC activity and CD40 signaling. J Leukoc Biol. 2013;94(6):1113-21.

Chadban SJ, Tesch GH, Foti R, Lan HY, Atkins RC, Nikolic-Paterson DJ. Interleukin-10 differentially modulates MHC class II expression by mesangial cells and macrophages in vitro and in vivo. Immunology (1998) 94(1):72-8.

Chang CY, Song MJ, Jeon SB, Yoon HJ, Lee DK, Kim IH, Suk K, Choi DK, Park EJ. Dual functionality of myeloperoxidase in rotenone-exposed brain-resident immune cells. Am J Pathol. 2011;179(2):964-79.

Chen Y, Lu H, Liu Q, Huang G, Lim CP, Zhang L, Hao A, Cao X. Function of GRIM-19, a mitochondrial respiratory chain complex I protein, in innate immunity. J Biol Chem. 2012;287(32):27227-35. 
Chouchani ET, Pell VR, Gaude E, Aksentijevic D, Sundier SY, Robb EL, Logan A, Nadtochiy SM, Ord ENJ, Smith AC, Eyassu F, Shirley R, Hu CH, Dare AJ, James AM, Rogarri S, Hartley RC, Eaton S, Costa ASH, Brookes PS, Davidson SM, Duchen MR, Saeb-Parsy K, Shattock MJ, Robinson AJ, Work LM, Frezza C, Krieg T, Murphy MP. Ischaemic accumulation of succinate controls reperfusion injury through mitochondrial ROS. Nature. 2014;515(7527):431-435.

Chujo T, Ohira T, Sakaguchi Y, Goshima N, Nomura N, Nagao A, Suzuki T. LRPPRC/SLIRP suppresses PNPase-mediated mRNA decay and promotes polyadenylation in human mitochondria. Nucleic Acids Res. 2012;40(16):8033-47.

Cloonan SM, Choi AM. Mitochondria in lung disease. J Clin Invest. 2016;126(3):809-20.

Colas E, Perez C, Cabrera S, Pedrola N, Monge M, Castellvi J, Eyzaguirre F, Gregorio J, Ruiz A, Llaurado M, Rigau M, Garcia M, Ertekin T, Montes M, Lopez-Lopez R, Carreras R, Xercavins J, Ortega A, Maes T, Rosell E, Doll A, Abal M, Reventos J, Gil-Moreno A. Molecular markers of endometrial carcinoma detected in uterine aspirates. Int J Cancer. 2011;129(10):2435-44.

Cox D, Berg JS, Cammer M, Chinegwundoh JO, Dale BM, Cheney RE, Greenberg S. Myosin $\mathrm{X}$ is a downstream effector of $\mathrm{PI}(3) \mathrm{K}$ during phagocytosis. Nat Cell Biol. 2002;4(7):469-77.

Dambuza IM, Brown GD. C-type lectins in immunity: recent developments. Curr Opin Immunol. 2015;32:21-7.

Das S, Yeung KT, Mahajan MA, Samuels HH. Fas Activated Serine-Threonine Kinase Domains 2 (FASTKD2) mediates apoptosis of breast and prostate cancer cells through its novel FAST2 domain. BMC Cancer. 2014;14:852.

DeFife KM, Jenney CR, Colton E, Anderson JM. Disruption of filamentous actin inhibits human macrophage fusion. FASEB J. 1999;13(8):823-32.

Delano MJ, Ward PA. Sepsis-induced immune dysfunction: can immune therapies reduce mortality? J Clin Invest. 2016;126(1):23-31.

Diaz F, Fukui H, Garcia S, Moraes CT. Cytochrome c oxidase is required for the assembly/stability of respiratory complex I in mouse fibroblasts. Mol Cell Biol. 2006;26(13):4872-81.

Distelmaier F, Koopman WJ, van den Heuvel LP, Rodenburg RJ, Mayatepek E, Willems $\mathrm{PH}$, Smeitink JA. Mitochondrial complex I deficiency: from organelle dysfunction to clinical disease. Brain. 2009;132(Pt 4):833-42.

Distelmaier F, Valsecchi F, Liemburg-Apers DC, Lebiedzinska M, Rodenburg RJ, Heil S, Keijer J, Fransen J, Imamura H, Danhauser K, Seibt A, Viollet B, Gellerich FN, Smeitink JA, Wieckowski MR, Willems PH, Koopman WJ. Mitochondrial dysfunction in primary human fibroblasts triggers an adaptive cell survival program that requires AMPK- $\alpha$. Biochim Biophys Acta. 2015;1852(3):529-40.

Droge W. Free radicals in the physiological control of cell function. Physiol Rev. 2002;82:47-95.

Dröse S. Differential effects of complex II on mitochondrial ROS production and their relation to cardioprotective pre- and postconditioning. Biochim Biophys Acta. 2013; 1827(5):578-87. 
Dupré-Crochet S, Erard M, Nüße O. ROS production in phagocytes: why, when, and where? J Leukoc Biol. 2013;94(4):657-70.

Eberhard S, Loiselay C, Drapier D, Bujaldon S, Girard-Bascou J, Kuras R, Choquet Y, Wollman FA. Dual functions of the nucleus-encoded factor TDA1 in trapping and translation activation of atpA transcripts in Chlamydomonas reinhardtii chloroplasts. Plant J. 2011;67(6):1055-66.

Emmrich JV, Hornik TC, Neher JJ, Brown GC. Rotenone induces neuronal death by microglial phagocytosis of neurons. FEBS J. 2013;280(20):5030-8.

Emre Y, Hurtaud C, Nübel T, Criscuolo F, Ricquier D, Cassard-Doulcier AM. Mitochondria contribute to LPS-induced MAPK activation via uncoupling protein UCP2 in macrophages. Biochem J. 2007;402(2):271-8.

Enríquez JA. Supramolecular Organization of Respiratory Complexes. Annu Rev Physiol. 2016;78:533-61.

Everts B, Amiel E, Huang SC, Smith AM, Chang CH, Lam WY, Redmann V, Freitas TC, Blagih J, van der Windt GJ, Artyomov MN, Jones RG, Pearce EL, Pearce EJ. TLRdriven early glycolytic reprogramming via the kinases TBK1-IKKE supports the anabolic demands of dendritic cell activation. Nat Immunol. 2014;15(4):323-32.

Fernández-Silva P, Enriquez JA, Montoya J. Replication and transcription of mammalian mitochondrial DNA. Exp Physiol. 2003;88(1):41-56.

Finn RD, Attwood TK, Babbitt PC, Bateman A, Bork P, Bridge AJ, Chan HY Dosztányi Z, Fraser M, Gough J, Haft D, Holliday GL, Huang H, Huang X, Letunic I, Lopez R, Lu S, Marchler-Bauer A, Mi H, Mistry J, Natale DA, Necci M, Nuka G, Orengo CA, Park Y, Pesseat S, Piovesan D, Potter SC, Rawlings ND, Redaschi N, Richardson L, Rivoire C, Sangrador-Vegas A, Sigrit C, Sillitoe I, Smithers B, Squizzato S, Sutton G, Thanki N, Thomas PD, Tosatto SC, Wu CH, Xenarios I, Yeh LS, Young SY, Mitchell AL.. InterPro in 2017-beyond protein family and domain annotations. Nucleic Acids Res. 2017;45(D1):D190-D199.

Fiorentino DF, Zlotnik A, Mosmann TR, Howard M, O'Garra A. IL-10 inhibits cytokine production by activated macrophages. J Immunol (1991) 147(11):3815-22.

Flannagan RS, Jaumouillé V, Grinstein S. The cell biology of phagocytosis. Annu Rev Pathol. 2012;7:61-98.

Fournier B. The function of TLR2 during staphylococcal diseases. Front Cell Infect Microbiol. 2013;2:167.

Franchini AM, Hunt D, Melendez JA, Drake JR. FCyR-driven release of IL-6 macrophages requires NOX2-dependent production of reactive oxygen species. $\mathrm{J}$ Biol Chem. 2013;30;288(35):25098-108.

Galluci S, Matzinger P. Danger signals: SOS to the immune system. Curr Opin Immunol 2001;13:114-119. 
Garaude J, Acín-Pérez R, Martínez-Cano S, Enamorado M, Ugolini M, Nistal-Villán E, Hervás-Stubbs S, Pelegrín P, Sander LE, Enríquez JA, Sancho S. Mitochondrial respiratory-chain adaptations in macrophages contribute to antibacterial host defense. Nat Immunol. 2016; 17(9);1037-1045.

García Del Río A, Delmiro A, Martín MA, Cantalapiedra R, Carretero R, Durántez C, Menegotto F, Morán M, Serrano-Lorenzo P, De la Fuente MA, Orduña A, Simarro $M$. The mitochondrial isoform of FASTK modulates nonopsonic phagocytosis of bacteria by macrophages via regulation of respiratory complex I. J Immunol. 2018;201(10):2977-2985.

Garzón I, Pérez-Köhler B, Garrido-Gómez J, Carriel V, Nieto-Aguilar R, Martín-Piedra MA, García-Honduvilla N, Buján J, Campos A, Alaminos M. Evaluation of the cell viability of human Wharton's jelly stem cells for use in cell therapy. Tissue Eng Part C Methods. 2012;18(6):408-19.

Gatti S, Beck J, Fantuzzi G, Bartfai T, Dinarello CA. Effect of interleukin-18 on mouse core body temperature. Am J Physiol Regul Integr Comp Physiol (2002) 282(3):R702-9.

Geissmann F, Manz MG, Jung S, Sieweke MH, Merad M, Ley K. Development of monocytes, macrophages, and dendritic cells. Science. 2010;327(5966):656-61.

Geng J, Sun X, Wang P, Zhang S, Wu H, Hong L, Xie C, Li X, Zhao H, Liu Q, Jiang M, Chen Q, Zhang J, Li Y, Song S, Wang HR, Zhou R, Johnson RL, Chien KY, Lin SC, Han J, Avruch J, Chen L, Zhou D. Kinases Mst1, and Mst2 positively regulate phagocytic induction of reactive oxygen species and bactericidal activity. Nat Immunol. 2015;16(11):1142-52.

Gilberti RM, Knecht DA. Macrophages phagocytose nonopsonized silica particles using a unique microtubule-dependent pathway. Mol Biol Cell. 2015;26(3):518-29.

Goodridge HS, Underhill DM, Touret N. Mechanisms of Fc receptor and dectin-1 activation for phagocytosis. Traffic. 2012;13(8):1062-71.

Gordon S. Pattern recognition receptors: doubling up for the innate immune response. Cell. 2002;111(7):927-30.

Gordon S, Taylor PR. Monocyte and macrophage heterogeneity. Nat Rev Immunol. 2005;5(12):953-64.

Gordon S. Phagocytosis: An Immunobiologic Process. Immunity. 2016;44(3):463-475.

Griffin GK, Newton G, Tarrio ML, Bu D-X, Maganto-Garcia E, Azcutia V, et al. IL-17 and TNF- $\alpha$ sustain neutrophil recruitment during inflammation through synergistic effects on endothelial activation. J Immunol (2012) 188(12):6287-99.

Grimm S. Respiratory chain complex II as general sensor for apoptosis. Biochim Biophys Acta. 2013;1827(5):565-72.

Guarás A, Perales-Clemente E, Calvo E, Acín-Pérez R, Loureiro-Lopez M, Pujol C, Martínez-Carrascoso I, Nuñez E, García-Marqués F, Rodríguez-Hernández MA, Cortés A, Diaz F, Pérez-Martos A, Moraes CT, Fernández-Silva $P$, Trifunovic $A$, Navas P, Vazquez J, Enríquez JA. The CoQH2/CoQ Ratio Serves as a Sensor of Respiratory Chain Efficiency. Cell Rep. 2016;15(1):197-209. 
Guezzi D, Saada A, D’Adamo P, Fernandez-Vizarra E, Gasparini P, Tiranti V, Elpeleg O, Zeviani M. FASTKD2 nonsense mutation in an infantile mitochondrial encephalomyopathy associated with cytochrome c oxidase deficiency. Am J Hum Genet. 2008;83(3):415-23.

Hall TM. De-coding and re-coding RNA recognition by PUF and PRR repeat protein. Curr Opin Struct Biol. 2016;36:116-21.

Han S, Udeshi ND, Deerinck TJ, Svinkina T, Ellisman MH, Carr SA, Ting AY. Proximity biotinylation as a method for mapping proteins associated with mtDNA in living cells. Cell Chem Biol. 2017;24(3):404-414.

Hanson PI, Roth R, Lin Y, Heuser JE. Plasma membrane deformation by circular arrays of ESCRT-II protein filaments. J Cell Biol. 2008;180(2):389-402.

He X, Zhou A, Lu H, Chen Y, Huang G, Yue X, Zhao P, Wu Y. Suppression of mitochondrial complex I influences cell metastatic properties. PLoS One. 2013;8(4):e61677.

Heale JP, Pollard AJ, Stokes RW, Simpson D, Tsang A, Massing B, Speert DP. Two distinct receptors mediate nonopsonic phagocytosis of different strains of Pseudomonas aeruginosa. J Infect Dis. 2001;183(8):1214-20.

Hendrickson SL, Lautenberger JA, Chinn LW, Malasky M, Sezgin E, Kingsley LA, Goedert JJ, Kirk GD, Gomperts ED, Buchbinder SP, Troyer JL, O'Brien SJ. Genetic variants in nuclear-encoded mitochondrial genes influence AIDS progression. PLos One. 2010;5(9):e12862.

Herre J, Marshall AS, Caron E, Edwards AD, Williams DL, Schweighoffer E, Tybulewicz V, Reis e Sousa C, Gordon S, Brown GD. Dectin-1 uses novel mechanisms for yeast phagocytosis in macrophages. Blood. 2004;104(13):4038-45.

Herrero A, Barja G. Localization of the site of oxygen radical generation inside the complex I of heart and nonsynaptic brain mammalian mitochondria. J Bioenerg Biomembr. 2000;32(6):609-15.

Herzig S, Shaw RJ. AMPK: guardian of metabolism and mitochondrial homeostasis. Nat Rev Mol Cell Biol. 2018;19(2):121-135.

Hoefs SJ, Rodenburg RJ, Smeitink, JA, van den Heuvel LP. Molecular base of biochemical complex I deficiency. Mitochondrion.2012;12(5):250-32.

Hou WL, Yin J, Alimujiang M, Yu XY, Ai LG, Bao YQ, Liu F, Jia WP. Inhibition of mitochondrial complex I improves glucose metabolism independently of AMPK activation. J Cell Mol Med. 2018;22(2):1316-1328.

Huang J, Canadien V, Lam GY, Steinberg BE, Dinauer MC, Magalhaes MA, Glogauer $\mathrm{M}$, Grinstein S, Brumell JH. Activation of antibacterial autophagy by NADPH oxidases. Proc Natl Acad Sci U S A. 2009;106(15):6226-31.

Huang SC, Evert B, Ivanova Y, O'Sullivan D, Nascimento M, Smith AM, Beatty W, LoveGregory L, Lam WY, O'Neill CM, Yan C, Du H, Abumrad NA, Urban JF Jr, Artyomov MN, Pearce EL, Pearce EJ. Cell-intrinsic lysosomal lipolysis is essential for alternative activation of macrophages. Nat Immunol. 2014;15(9):846-55. 
Hurst SM, Wilkinson TS, McLoughlin RM, Jones S, Horiuchi S, Yamamoto N, et al. IL-6 and its soluble receptor orchestrate a temporal switch in the pattern of leukocyte recruitment seen during acute inflammation. Immunity (2001) 14(6):705-14.

Huynh KK, Eskelinen EL, Scott CC, Malevanets A, Saftig P, Grinstein S. LAMP proteins are required for fusion of lysosomes with phagosomes. EMBO J. 2007;26(2):31324.

Italiani $\mathrm{P}$, Boraschi D. From monocytes to M1/M2 macrophages: phenotypical vs. functional differentiation. Front Immunol. 2014;5:514.

Iwasaki A, Medzhitov R. Control of adaptive immunity by the innate immune system. Nat Immunol. 2015;16(4):343-53.

Iwasaki A, Medzhitov R. Regulation of adaptive immunity by the innate immune system. Science. 2010;15;327(5963):291-5.

Izquierdo JM, Valcárcel J. Fas-activated serine/threonine kinase (FASTK) synergizes with TIA-1/TIAR proteins to regulate Fas alternative splicing. J Biol Chem. $2007 ; 282(3) ; 1539-43$.

Janeway CA Jr, Medzhitov R. Innate Immune Recognition. Annu Rev Immunol. 2002. 20:197-216.

Janssen RJ, Nijtmans LG, van den Heuvel LP, Smeitink JA. Mitochondrial complex I: structure, function and pathology. J Inherit Metab Dis. 2006;29(4):499-515.

Jaokar TM, Patil DP, Shouche YS, Gaikwad SM, Suresh CG. Human mitochondrial NDUFS3 protein bearing Leigh syndrome mutation is more prone to aggregation than its wild-type. Biochimie. 2013;95(12):2392-403.

Jenkins SJ, Hume DA. Homeostasis in the mononuclear phagocyte system. Trends Immunol 2014;35:358-367.

Jenkins Y, Sun TQ, Markovtsov V, Foretz M, Li W, Nguyen H, Li Y, Pan A, Uy G, Gross L, Baltgalvis K, Yung SL, Gururaja T, Kinoshita T, Owyang A, Smith IJ, McCaughey K, White K, Godinez G, Alcantara R, Choy C, Ren H, Basile R, Sweeny DJ, Xu X, Issakani SD, Carroll DC, Goff DA, Shaw SJ, Singh R, Boros LG, Laplante MA, Marcotte B, Kohen R, Viollet B, Marette A, Payan DG, Kinsella TM, Hitoshi Y. AMPK activation through mitochondrial regulation results in increased substrate oxidation and improved metabolic parameters in models of diabetes. PLoS One. 2013;8(12):e81870.

Jeong $\mathrm{E}$, Lee JY. Intrinsic and extrinsic regulation of innate immune receptors. Yonsei Med J. 2011;52(3):379-92.

Jeong HW, Hsu KC, Lee JW, Ham M, Huh JY, Shin HJ, Kim WS, Kim JB. Berberine suppresses proinflammatory responses through AMPK activation in macrophages. Am J Physiol Endocrinol Metab. 2009;296(4):E955-64.

Jha AK, Huang SC, Sergushichev A, Lampropoulou V, Ivanova Y, Loginicheva E, Chmielewski K, Stewart KM, Ashall J, Everts B, Pearce EJ, Driggers EM, Artyomov MN. Network integration of parallel metabolic and transcriptional data reveals metabolic modulates that regulate macrophage polarization. Immunity. 2015;42(3):419-30. 
Jin Z, Wei W, Yang M, Du Y, Wan Y. Mitochondrial complex I activity suppresses inflammation and enhances bone resorption by shifting macrophage-osteoclast polarization. Cell Metab. 2014;20(3):483-98.

Jourdain AA, Boehm E, Maundrell K, Martinou JC. Mitochondrial RNA granules: Compartmentalizing mitochondrial gene expression. J Cell Biol. 2016;212(6):6114.

Jourdain AA, Koppen M, Rodley CD, Maundrell K, Gueguen N, Reynier P, Guaras AM, Enriquez JA, Anderson P, Simarro M, Martinou JC. A mitochondria-specific isoform of FASTK is present in mitochondrial RNA granules and regulates gene expression and function. Cell Rep. 2015;10(7):1110-21.

Jourdain AA, Koppen M, Wydro M, Rodley CD, Lightowlers RN, ChrzanowskaLightowlers ZM, Martinou JC. GRSF1 regulates RNA processing in mitochondrial RNA granules. Cell Metab. 2013;17(3):399-410.

Jourdain AA, Popow J, de la Fuente MA, Martinou JC, Anderson P, Simarro M. The FASTK family of proteins: emerging regulators of mitochondrial RNA biology. Nucleic Acids Res. 2017;45(19):10941-10947.

Kahlhöfer F, Kmita K, Wittig I, Zwicker K, Zickermann V. Accessory subunit NUYM (NDUFS4) is required for stability of the electron input module and activity of mitochondrial complex I. Biochim Biophys Acta Bienerg. 2017;1858(2):175-181.

Kawai T, Akira S. Toll-like receptor and their crosstalk with other innate receptors in infection and immunity. Immunity. 2011; 34(5):637-50.

Kedersha N, Stoecklin G, Ayodele M, Yacono P, Lykke-Andersen J, Fritzler MJ, Scheuner D, Kaufman RJ, Golan DE, Anderson P. Stress granules and processing bodies are dynamically linked sites of mRNP remodeling. J Cell Biol. 2005;169(6);871-84.

Kelly B, Tannahill GM, Murphy MP, O’Neill LA. Metformin Inhibits the Production of Reactive Oxygen Species from NADH: Ubiquinone Oxidoreductase to Limit Induction of Interleukin-1 $\beta$ (IL-1 $\beta$ ) and Boosts Interleukin-10 (IL-10) in Lipopolysaccharide (LPS)-activated Macrophages. J Biol Chem. 2015;290(33):20348-59.

Kim J, Yang G, Kim Y, Kim J, Ha J. AMPK activators: mechanisms of action and physiological activities. Exp Mol Med. 2016;48:e224.

Kleinknecht L, Wang F, Stübe R, Philippar K, Nickelsen J, Bohne AV. RAP, the sole octotricopeptide repeat protein in Arabidopsis, is required for chloroplast $16 \mathrm{~S}$ rRNA maturation. Plant Cell. 2014;26(2):777-87.

Koopman WJ, Verkaart S, Visch HJ, van den Westhuizen FH, Murphy MP, van der Heuvel LW, Smeitink JA, Willems PH. Inhibition of complex I of the electron transport chain causes O2-. -mediated mitochondrial outgrowth. Am J Physiol Cell Physiol. 2005;288(6):C1440-50. 
Krawczyk CM, Holowka T, Sun J, Blagih J, Amiel E, DeBerardinis RJ, Cross JR, Jung E, Thompson CB, Jones RG, Pearce EJ. Toll-like receptor-induced changes in glycolytic metabolism regulate dendritic cell activation. Blood. 2010;115(23):47429.

Kruse SE, Watt WC, Marcinek DJ, Kapur RP, Schenkman KA, Palmiter RD. Mice with mitochondrial complex I deficiency develop a fatal encephalomyopathy. Cell Metab. 2008;7(4):312-20.

Kühlbrandt W. Structure and function of mitochondrial membrane protein complexes. BMC Biol. 2015;13:89.

Kutner RH, Zhang XY, Reiser J. Production, concentration and titration of pseudotyped HIV-1 based lentiviral vector. Nat Protoc. 2009;4(4):495-505.

Labuzek K, Liber S, Gabryel B, Adamczyk J, Okopien B. Metformin increases phagocytosis and acidifies lysosomal/endosomal compartments in AMKdependent manner in rat primary microglia. Naunyn Schmiedebergs Arch Pharmacol. 2010;381(2):171-86.

Lachmandas E, Boutens L, Ratter JM, Hijmans A, Hooiveld GJ, Joosten LA, Rodenburg RJ, Fransen JA, Houtkooper RH, van Crevel R, Netea MG, Stienstra R. Microbial stimulation of different Toll-like receptor signaling patways induces diverse metabolic programmes in human monocytes. Nat Microbiol. 2016;2:16246.

Lambeth JD. NOX enzymes and the biology of reactive oxygen. Nat Rev immunol. 2004;4(3):181-9.

Lapuente-Brun E, Moreno-Loshuertos R, Acín-Pérez R, Latorre-Pellicer A, Colás C, Balsa E, Perales-Clemente E, Quirós PM, Calvo E, Rodríguez-Hernández MA, Navas $P$, Cruz R, Carracedo Á, López-Otín C, Pérez-Martos A, Fernández-Silva $P$, Fernández-Vizarra $E$, Enríquez JA. Supercomplex assembly determines electron flux in the mitochondrial electron transport chain. Science. 2013;340(6140):1567-70.

Laroux FS, Romero X, Wetzler L, Engel P, Terhorst C. Cutting edge: MyD88 controls phagocyte NADPH oxidase function and killing of gram-negative bacteria. $J$ Immunol. 2005;175(9):5596-600.

Lee I, Hong W. RAP -a putative RNA-binding domain. Trends Biochem Sci. 2004;29(11):567-70.

Lenaz G, Fato R, Genova ML, Bergamini C, Bianchi C, Biondi A. Mitochondrial complex I: structural and functional aspects. Biochim Biophys Acta. 2006;1757(9-10):140620.

Levin R, Grinstein S, Canton J. The life cycle of phagosomes: formation, maturation, and resolution. Immunol Rev. 2016; 273(1):156-79.

Li N, Ragheb K, Lawler G, Sturgis J, Rajwa B, Melendez JA, Robinson JP. Mitochondrial complex I inhibitor rotenone induces apoptosis through enhancing mitochondrial reactive oxygen species production. J Biol Chem. 2003;278(19):8516-25.

Li Y, Park JS, Deng JH, Bai Y. Cytochrome c oxidase subunit IV is essential for assembly and respiratory function of the enzyme complex. J Bioenerg Biomembr. 2006;38(56):283-91. 
Lim J, Coates CJ, Seoane PI, Garelnabi M, Taylor-Smith LM, Monteith P, Macleod CL, Escaron CJ, Brown GD, Hall RA, May RC. Characterizing the mechanisms of nonopsonic uptake of Crytococcy by macrophages. $\mathrm{J}$ Immunol. 2018;200(19):3539-3546.

Liu N, Li Y, Dong C, Xu X, Wei P, Sun W, Peng Q. Inositol-Requiring Enzyme 1Dependent Activation of AMPK Promotes Brucella abortus Intracellular Growth. J Bacteriol. 2016;198(6):986-93.

Loh SH, Francescut L, Lingor P, Bähr M, Nicotera P. Identification of new kinase clusters required for neurite outgrowth and retraction by a loss-of-function RNA interference screen. Cell Death Differ. 2008;15(2):283-98.

Maas K, Chan S, Parker J, Slater A, Moore J, Olsen N, Aune TM. Cutting edge: molecular portrait of human autoimmune disease. J Immunol. 2002;169(1):5-9.

Mackenzie RM, Salt IP, Miller WH, Logan A, Ibrahim HA, Degasperi A, Dymott JA, Hamilton CA, Murphy MP, Delles C, Dominiczak AF. Clin Sci (Lon). 2013;124(6):403-11.

Mahfouz RZ, Sharma R, Lackner J, Aziz N, Agarwal A. Evaluation of chemiluminescence and flow cytometry as tools in assessing production of hydrogen peroxide and superoxide anion in human spermatozoa. Fertil Steril 2009;92:819-827.

Male D, Brostoff J, Roth DB, Roitt I. Immunology. $8^{\circ}$ ed. Elsevier; 2013.

Malik M, Simpson JF, Parikh I, Wilfred BR, Fardo DW, Nelson PT, Estus S. CD33 Alzheimer's risk-altering polymorphism, CD33 expression, and exon 2 splicing. J Neurosci. 2013;33(33):13320-5.

Mao Y Finnemann SC. Regulation of phagocytosis by Rho GTPases. Small GTPases. 2015;6(2):89-99.

Marchand JB, Kaiser DA, Pollard TD, Higgs HN. Interaction of WASP/Scar proteins with actin and vertebrate Arp2/3 complex. Nat Cell Biol. 2001;3(1):76-82.

Marie-Anaïs F, Mazzolini J, Herit F, Niedergang F. Dynamin-Actin cross talk contributes to phagosome formation and closure. Traffic. 2016;17(5):487-99.

Martínez FO, Gordon S. The M1 and M2 paradigm of macrophage activation: time for reassessment. F1000Prime Rep. 2014;6:13.

Maselli A, Laevsky G, Knecht DA. Kinetics of binding, uptake and degradation of live fluorescent (DsRed) bacteria by Dictyostelium discoideum. Microbiology. 2002;148(Pt 2):413-20.

Medzhitov R. Recognition of microorganisms and activation of the immune response. Nature 2007;449;819-826.

Meng S, Cao J, He Q, Xiong L, Chang E, Radovick S, Wondisford FE, He L. Metformin activates AMP-activated protein kinase by promoting formation of the $\alpha \beta \gamma$ heterotrimeric complex. J Biol Chem. 2015;290(6):3793-802. 
Michelucci A, Cordes T, Gueffi J, Pailot A, Reiling N, Goldmann O, Binz T, Wegner A, Tallam A, Rausell A, Buttini M, Linster CL, Medina E, Balling R, Hiller K. Immuneresponsive gene 1 protein links metabolism to immunity by catalyzing itaconic acid production. Proc Natl Acad Sci U S A. 2013;110(19):7820-5.

Mihaylova MM, Shaw RJ. The AMPK signaling pathway coordinates cell growth, autophagy and metabolism. Nat Cell Biol. 2011;13(9):1016-23.

Mills EL, Kelly B, Logan A, Costa ASH, Varma M, Bryant CE, Tourlomousis P, Däbritz JHM, Gottlieb E, Latorre I, Corr SC, McManus G, Ryan D, Jacobs HT, Szibor M, Xavier RJ, Braun T, Frezza C, Murphy MP, O’Neill LA. Succinate dehydrogenase supports metabolic repurposing of mitocondria to drive inflammatory macrophages. Cell. 2016;167(2):457-470.

Mills EL, O'Neill LA. Reprogramming mitochondrial metabolism in macrophages as an anti-inflammatory signal. Eur J Immunol. 2016;46(1):13-21.

Mills E, O'Neill LA. Succinate: a metabolic signal in inflammation. Trends Cell Biol. 2014;24(5):313-20.

Mills EL, Ryan DG, Prag HA, Dikovskaya D, Menon D, Zaslona Z, Jedrychowski MP, Costa ASH, Higgins M, Hams E, Szpyt J, Runtsch MC, King MS, McGouran JF, Fischer R, Kessler BM, McGettrick AF, Hughes MM, Carroll RG, Booty LM, Knatko EV, Meakin PJ, Ashford MLJ, Modis LK, Brunori G, Sévin DC, Fallon PG, Caldwell ST, Kunji ERS, Chouchani ET, Frezza C, Dinkova-Kostova AT, Hartley RC, Murphy MP, O'Neill LA. Itaconate is an anti-inflammatory metabolite that activates Nrf2 via alkylation of KEAP1. Nature. 2018;556(7699):113-117.

Mishra P, Chan DC. Mitochondrial dynamics and inheritance during cell division, development and disease. Nat Rev Mol Cell Biol. 2014;15(10):634-46.

Moon JS, Lee S, Park MA, Siempos II, Haslip M, Lee PJ, Yun M, Kim CK, Howrylak J, Ryter SW, Nakahira K, Choi AM. UCP2-induced fatty acid synthase promotes NLRP3 inflammasome activation during sepsis. J Clin Invest. 2015;125(2):665-80

Mork T, Hancock RE. Mechanisms of nonopsonic phagocytosis of Pseudomonas aeruginosa. Infect Immun. 1993;61(8):3287-93.

Mounier R, Théret M, Arnold L, Cuvellier S, Bultot L, Göransson O, Sanz N, Ferry A, Sakamoto K, Foretz M, Viollet B, Chazaud B. AMPK $\alpha 1$ regulates macrophage skewing at the time of resolution of inflammation during skeletal muscle regeneration. Cell Metab. 2013;18(2):251-64.

Murphy MP. Mitochondrial dysfunction indirectly elevates ROS production by the endoplasmic reticulum. Cell Metab. 2013;18(2):145-6.

Murphy, MP. How mitochondria produce reactive oxygen species. Biochem J. 2009;417(1):1-13.

Nagaike T, Suzuki T, Katoh T, Ueda T. Human mitochondrial mRNAs are stabilized with polyadenylation regulated by mitochondria-specific poly(A) polymerase and polynucleotide phosphorylase. J Biol Chem. 2005;280(20):19721-7. 
Nakano A, Kato H, Watanabe T, Min KD, Yamazani S, Asano Y, Seguchi O, Higo S, Shintani Y, Asanuma H, Asakura M, Minamino T, Kaibuchi K, Mochizuki N, Kitakaze M, Takashima S. AMPK control the speed of microtubule polymerization and directional cell migration through CLIP-170 phosphorylation. Nat Cell Biol. 2010;12(6):583-90.

Naujoks J, Tabeling C, Dill BD, Hoffmann C, Brown AS, Kunze M, Kempa S, Peter A, Mollenkopf HJ, Dorhoi A, Kershaw O, Gruber AD, Sander LE, Witzenrath M, Herold S, Nerlich A, Hocke A, Hocke AC, van Driel I, Suttorp N, Bedoui S, Hilbi H, Trost M, Opitz B. IFNs Modify the Proteome of Legionella-Contaning Vacuoles and Restrict Infection Via IRG1-Derived Itaconic Acid. PLoS Pathog. 2016;12(2):e1005408.

Nunes P, Demaurex N. The role of calcium signaling in phagocytosis. J Leukoc Biol. 2010;88(1):57-68.

O'Neill LA, Pearce EJ. Immunometabolism governs dendritic cell and macrophage function. J Exp Med. 2016;213(1):15-23.

Ofek I, Goldhar J, Keisari Y, Sharon N. Nonopsonic phagocytosis of microorganisms. Annu Rev Microbiol. 1995;49:239-76.

Ohman L, Hed J, Stendahl O. Interaction between human polymorphonuclear leukocytes and two different strains of type 1 fimbriae-bearing Escherichia coli. J Infect Dis. 1982;146(6):751-7.

Ohto U, Fukase K, Miyake K, Shimizu T. Structural basis of species-specific endotoxin sensing by innate immune receptor TLR4/MD-2. Proc Natl Acad Sci U S A; 109(19):7421-6.

Ortigoza-Escobar JD, Oyarzabal A, Montero R, Artuch R, Jou C, Jiménez C, Gort L, Briones P, Muchart J, López-Gallardo E, Emperador S, Pesini ER, Montoya J, Pérez B, Rodríguez-Pombo $P$, Pérez-Dueñas B. Ndufs4 related Leigh syndrome: A case report and review of the literature. Mitochondrion. 2016;28:73-8.

Pagniez-Mammeri H, Loublier S, Legrand A, Bénit P, Rustin P, Slama A. Mitochondrial complex I deficiency of nuclear origin I. Structural genes. Mol Genet Metab. 2012;105(2):163-72.

Palorini R, Simonetto T, Cirulli C, Chiaradonna F. Mitochondrial complex I inhibitors and forced oxidative phosphorylation synergize in inducing cancer cell death. Int J Cell Biol. 2013;2013:243876.

Park D, Han CZ, Elliot MR, Kinchen JM, Trampont PC, Das S, Collins S, Lysiak JJ, Hoehn KL, Ravichandran KS. Continued clearance of apoptotic cells critically depends on the phagocyte Ucp2 protein. Nature. 2011;477(7363):220-4.

Park DW, Jiang S, Tadie JM, Stigler WS, Gao Y, Deshane J, Abraham E, Zmijewski JW. Activation of AMPK enhances neutrophil chemotaxis and bacterial killing. Mol Med. 2013;19:387-98.

Parkin J, Cohen B. An overview of the immune system. Lancet. 2001; 357(9270):177789. 
Pauwels AM, Trost M, Beyaert R, Hoffmann E. Patterns, Receptors, and Signals: Regulation of Phagosome Maturation. Trends Immunol. 2017;38(6):407-422.

Pavia CN, Bozza MT. Are reactive oxygen species always detrimental to pathogens? Antioxid Redox Signal. 2014;20(6):1000-37.

Pellegrino MW, Haynes CM. Mitophagy and the mitochondrial unfolded protein response in neurodegeneration and bacterial infection. BMC Biol. 2015;13:22.

Peruń A, Biedroń R, Konopiński MK, Białecka A, Marcinkiewicz J, Józefowski S. Phagocytosis of live versus killed or fluorescently labeled bacteria by macrophages differ in both magnitude and receptor specificity. Immunol Cell Biol. 2017;95(5):424-435.

Popow J, Alleaume AM, Curk T, Schwarzl T, Sauer S, Hentze MW. FASTKD2 is an RNAbinding protein required for mitochondrial RNA processing and translation. RNA. 2015;21(11):1873-84.

Prasad A, Rabionet R, Espinet B, Zapata L, Puiggros A, Melero C, Puig A, Sarria-Trujillo Y, Ossowski S, Garcia-Muret MP, Estrach T, Servitje, Lopez-Lerma I, Gallardo F, Pujol RM, Estivill X. Identification of gene mutations and fusion genes in patients with Sézary syndrome. J Invest Dermatol. 2016;136(7):1490-1499.

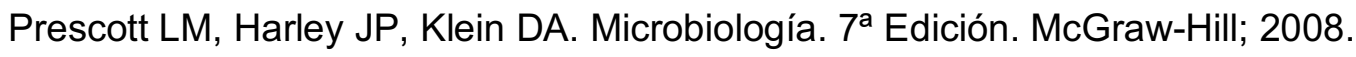

Pyle A, Smertenko T, Bargiela D, Griffin H, Duff J, Appleton M, Douroudis K, Pfeffer G, Santibanez-Koref M, Eglon G, Yu-Wai-Man P, Ramesh V, Horvath R, Chinnery PF. Exome sequencing in undiagnosed inherited and sporadic ataxias. Brain. 2015;138(Pt 2):276-83.

Quan H, Kim JM, Lee HJ, Lee SH, Choi JI, Bae HB. AICAR Enhances the Phagocytic Ability of Macrophages towards Apoptotic Cells through P38 Mitogen Activated Protein Kinase Activation Independent of AMP-Activated Protein Kinase. PLoS One. 2015;10(5):e0127885.

Quintero M, Colombo SL, Godfrey A, Moncada S. Mitochondria as signaling organelles in the vascular endothelium. Proc Natl Acad Sci U S A. 2006;103(14):5379-84.

Rabinovitch RC, Samborska B, Faubert B, Ma EH, Gravel SP, Andrzejewski S, Raissi TC, Pause A, St-Pierre J, Jones RG. AMPK Maintains Cellular Metabolic Homeostasis through Regulation of Mitochondrial Reactive Oxygen Species. Cell Rep. 2017;21(1):1-9.

Ramanan VK, Nho K, Shen L, Risacher SL, Kim S, McDonald BC, Farlow MR, Foroud TM, Gao S, Soininen H, Kloszewska I, Mecocci P, Tsolaki M, Vellas B, Lovestone S, Aisen PS, Petersen RC, Kack CR Jr, Shaw LM, Trojanowski JQ, Weiner MW, Green RC, Toga AW, De Jager PL, Yu L, Bennett DA, Saykin AJ. FASTKD2 is associated with memory and hippocampal structure in older adults. Mol Psychiatry. 2015a;20(10):1197-204.

Ramanan VK, Saykin AJ. FASTKD2 and human memory: functional pathways and prospects for novel therapeutic target development for Alzheimer's disease and age-associated memory decline. Pharmacogenomics. 2015b;16(5):429-32. 
Rodríguez-Prados JC, Través PG, Cuenca J, Rico D, Aragonés J, Martín-Sanz P, Cascante M, Boscá L. Substrate fate in activated macrophages: a comparison between innate, classic, and alternative activation. J Immunol. 2010;185(1):60514.

Rosales C, Uribe-Querol E. Phagocytosis: A Fundamental Process in Immunity. Biomed Res Int. 2017;2017;9042851.

Rossmanith W. Localization of human RNase Z isoforms: dual nuclear/mitochondrial targeting of the ELAC2 gene production by alternative translation initiation. PLoS One. 2011;6(4):e19152.

Rousset S, Emre Y, Join-Lambert O, Hurtaud C, Ricquier D, Cassard-Doulcier AM. The uncoupling protein 2 modulates the cytokine balance in innate immunity. Cytokine. 2006;35(3-4):135-42.

Sancho D, Enamorado M, Garaude J. Innate Immune Function of Mitochondrial Metabolism. Front Immunol. 2017;8:527.

Santarino IB, Viegas MS, Domingues NS, Ribeiro AM, Soares MP, Vieira OV. Involvement of the p62/NRF2 signal transduction pathway on erythrophagocytosis. Sci Rep. 2017;7(1):5812.

Sarasquete ME, Martínez-López J, Chillón MC, Alcoceba M, Corchete LA, Paiva B, Puig N, Sebastián E; Jiménez C, Mateos MV, Oriol A, Rosiñol L, Palomera L, Teruel Al, González Y, Lahuerta JJ, Bladé J, Gutiérrez NC, Fernández-Redondo E, González M, San Miguel JF, García-Sanz R. Evaluating gene expression profiling by quantitative polymerase chain reaction to develop a clinically feasible test for outcome prediction in multiple myeloma. Br J. Haematol. 2013;163(2):223-34.

Schapira AH. Mitochondrial disease. Lancet. 2006;368(9529):70-82.

Scheller J, Chalaris A, Schmidt-Arras D, Rose-John S. The pro- and anti- inflammatory properties of the cytokine interleukin-6. Biochim Biophys Acta (2011) 1813(5):87888.

Schlam D, Bagshaw RD, Freeman SA, Collins RF, Pawson T, Fairn GD, Grinstein S. Phosphoinositide 3-kinase enables phagocytosis of large particles by terminating actin assembly through Rac/Cdc42 GTPase-activating proteins. Nat Commun. 2015;6:8623.

Schon EA, DiMauro S, Hirano M. Human mitochondrial DNA: roles of inherited and somatic mutations. Nat Rev Genet. 2012;13(12):878-90.

Schroder K, Tschopp J. The inflammasomes. Cell. 2010;140(6):821-32.

Sekar S, McDonald J, Cuyugan L, Aldrich J, Kurdoglu A, Adkins J, Serrano G, Beach TG, Craig DW, Valla J, Reiman EM, Liang WS. Alzheimer's disease is associated with altered expression of genes involved in immune response and mitochondrial processes in astrocytes. Neurobiol Aging. 2015;36(2):583-91.

Sena LA, Chandel NS. Physiological roles of mitochondrial reactive oxygen species. Mol Cell. 2012;48(2):158-67. 
Sevcikova S, Paszekova H, Besse L, Sedlarikova L, Kubaczkova V, Almasi M, Pour L, Hajek R. Extramedullary relapse of multiple myeloma defined as the highest risk group based on deregulated gene expression data. Biomed Pap Med Fac Univ Olomouc Czech Repub. 2015;159(2):288-93.

Shtir C, Aldahmesh MA, Al-Dahmash S, Abboud E, Alkuraya H, Abouammoh MA, Nowailaty SR, Al-Thubaiti G, Naim EA, ALYounes B, Binhumaid FS, ALOtaibi AB, Altamimi AS, Alamer FH, Hashem M, Abouelhoda M, Monies D, Alkuraya FS. Exome-based case-control association study using extreme phenotype design reveals novel candidates with protective effect in diabetic retinopathy. Hum Genet. 2016;135(2):193-200.

Simarro M, Chen M, De la Fuente MA, Eiros JM, Orduña A, Anderson P. Deletion of FAST (Fas-activated serine/threonine phosphoprotein) ameliorate immune complex arthritis in mice. Mod Rheumatol. 2016;26(4):630-2.

Simarro M, Giannattasio G, De la Fuente MA, Benarafa C, Subramanian KK, Ishizawar R, Balestrieri B, Andersson EM, Luo HR, Orduña A, Boyce J, Anderson P. Fasactivated serine/threonine phosphoprotein promotes immune-mediated pulmonary inflammation. J Immunol. 2010b;184(9):5325-32.

Simarro M, Gimenez-Cassina A, Kedersha N, Lazaro JB, Adelmant GO, Marto JA, Rhee K, Tisdale S, Danial N, Benarafa C, Orduña A, Anderson P. Fast kinase domaincontaining protein 3 is a mitochondrial protein essential for cellular respiration. Biochem Biphys Res Commun. 2010a;401(3):440-6.

Simarro M, Mauger D, Rhee K, Pujana MA, Kedersha NL, Yamasaki S, Cusick ME, Vidal M, Garcia-Blanco MA, Anderson P. Fas-activated serine/threonine phophoprotein (FAST) is a regulator of alternative splicing. Proc Natl Acad Sci $U S A$. 2007;104(27):11370-5.

Sokolovska A, Becker CE, Ip WK, Rathinam VA, Brudner M, Paquette N, Tanne A, Vanaja SK, Moore KJ, Fitzgerald KA, Lacy-Hulbert A, Stuart LM. Activation of caspase-1 by the NLRP3 inflammasome regulates the NADPH oxidase NOX2 to control phagosome function. Nat Immunol. 2013;14(6):543-53.

Sonoda J, Laganiére J, Mehl IR, Barish GD, Chong LW, Li X, Scheffler IE, Mock DC, Bataille AR, Robert F, Lee CH, Giguère V, Evans RM. Nuclear receptor ERR alpha and coactivator PGC-1 beta are effectors of IFN-gamma-induced host defense. Genes Dev. 2007;21(15):1909-20.

Stanley IA, Ribeiro SM, Giménez-Cassina A, Norberg E, Danial NN. Changing appetites: the adaptive advantages of fuel choice. Trends Cell Biol. 2014;24(2):118-27.

Stokes RW, Thorson LM Speert DP. Nonopsonic and opsonic association of Mycobacterium tuberculosis with resident alveolar macrophages is inefficient. $J$ Immunol. 1998;160(11):5514-21.

Stumhofer JS, Laurence A, Wilson EH, Huang E, Tato CM, Johnson LM, et al. Interleukin 27 negatively regulates the development of interleukin 17-producing Thelper cells during chronic inflammation of the central nervous system. Nat Immunol (2006) 7(9):937-45.

Suhane S, Kanzani H, Arumugaswami V, Murali R, Ramanujan VK. Mitochondrial NDUFS3 regulates the ROS-mediated onset of metabolic switch in transformed cells. Biol Open. 2013; 2(3):295-305. 
Sulahin TH, Imrich A, Deloid G, Winkler AR, Kobzik L. Signaling pathways required for macrophage scavenger receptor-mediated phagocytosis: analysis by scanning cytometry. Respir Res. 2008;9:59.

Takeda K, Akira S. TLR signaling pathways. Semin Immunol. 2004;16(1):3-9.

Takeuchi O, Akira S. Pattern recognition receptors and inflammation. Cell. 2010;140(6):805-20.

Tang Y, Garson K, Li L, Vanderhyden BC. Optimization of lentiviral vector production using polyethylenimine-mediated transfection. Oncol Lett. 2015;9(1):55-62.

Tannahill GM, Curtis AM, Adamik J, Palsson-McDermott EM, McGettrick AF, Goel G, Frezza C, Bernard NJ, Kelly B, Foley NH, Zheng L, Gardet A, Tong Z, Jany SS, Corr SC, Haneklaus M, Caffrey BE, Pierce K, Walmsley S, Beasley FC, Cummins E, Nizet V, Whyte M, Taylor CT, Lin H, Masters SL, Gottlieb E, Kelly VP, Clish C, Auron PE, Xavier RJ, O'Neill LA. Succinate is an inflammatory signal that induces IL-1 $\beta$ through HIF-1 $\alpha$. Nature. 2013;496(7444):238-42.

Temperley RJ, Wydro M, Lightowlers RN, Chrzanowska-Lightowlers ZM. Human mitochondrial mRNAs-like members of all families, similar bur different. Biochim Biophys Acta. 2010;1797(6-7):1081-5.

Thompson RJ, Buttigieg J, Zhang M, Nurse CA. A rotenone-sensitive site and $\mathrm{H} 2 \mathrm{O} 2$ are key components of hypoxia-sensing in neonatal rat adrenomedullary chromaffin cells. Neuroscience. 2007;145(1):130-41.

Tissières $\mathrm{P}$, Pugin J. The role of MD-2 in the opsonophagocytosis of Gram-negative bacteria. Curr Opin Infect Dis. 2009;22(3):286-91.

Triantafilou M, Gamper FG, Haston RM, Mouratis MA, Morath S, Hartung T, Triantafilou K. Membrane sorting of toll-like (TLR)-2/6 and TLR2/1 heterodimers at the cell surface determines heterotypic associations with CD36 and intracellular targeting. J Biol Chem. 2006;13;281(41):31002-11.

Tuppen HA, Blakely EL, Turnbull DM, Taylor RW. Mitochondrial DNA mutations and human disease. Biochim Biophys Acta. 2010;1797(2):113-28.

Underhill D, Goodridge H. Information processing during phagocytosis. Nat Rev Immunol. 2012;12(7):492-502.

Underhill D, Ozinsky A. Phagocytosis of microbes: Complexity in Action. Annu. Rev. Immunol. 2002b. 20:825-52.

Underhill D, Ozinsky A. Toll-like receptors: key mediators of microbe detection. Curr Opin Immunol 2002a;14(1):103-10.

Underhill D. Toll-like receptors and microbes take aim at each other. Curr Op Immunology. 2004, 16;483-487.

Uribe-Querol E, Rosales C. Control of phagocytosis by microbial pathogens. Front Immunol. 2017;8:1368. 
van Doorn R, van Kester MS, Dijkman R, Vermeer $M H$, Mulder AA, Szuhai K, Knijnenburg J, Boer JM, Willemze R, Tensen CP. Oncogenomic analysis of mycosis fungoides reveals major differences with Sezary syndrome. Blood. 2009;113(1):127-36.

van Lookeren Campagne M, Wiesmann C, Brown EJ. Macrophage complement receptors and pathogen clearance. Cell Micobiol. 2007;9(9):2095-102.

Varghese RT, Liang Y, Guan T, Franck CT, Kelly DF, Sheng Z. Survival kinase genes present prognostic significance in glioblastoma. Oncotarget. 2016;7(15):20140-51.

Viegas MS, Estronca LM, Vieira OV. Comparison of the kinetics of maturation of phagosomes containing apoptotic cells and lgG-opsonized particles. PLoS One. 2012;7(10):e48391.

Vieira OV, Botelho RJ, Grinstein S. Phagosome maturation: aging gracefully. Biochem J. 2002;366(Pt 3):689-704.

Vinothkumar KR, Zhu J, Hirst J. Architecture of mammalian respiratory complex I. Nature. 2014;515(7525):80-84.

Vogel RO, Dieteren CE, van den Heuvel LP, Willems PH, Smeitink JA, Koopman WJ, Nijtmans LG. Identification of mitochondrial complex I assembly intermediates by tracing tagged NDUFS3 demonstrates the entry point of mitochondrial subunits. J Biol Chem. 2007;282(10):7582-90.

Wang JQ, Jeelall YS, Ferguson LL, Horikawa K. Toll-Like Receptor and Cancer: MYD88 Mutation and Inflammation. Front Immunol. 2014;5:367.

Wang QQ, Li H, Oliver T, Glogauer M, Guo J, He YW. Integrin beta 1 regulates phagosome maturation in macrophages through Rac expression. J Immunol. 2008;15;180(4):2419-28.

Webster ML, Zhu G, Li Y, Ni H. Fc-independent phagocytosis: implications for intravenous IgG therapy in immune thrombocytopenia. Cardiovasc Hematol Disord Drug Targets. 2008;8(4):278-82.

Weigl S, Paradiso A, Tommasi S. Mitochondria and familial predisposition to breast cancer. Curr Genomics. 2013;14(3):195-203.

Weinberg SE, Sena LA, Chandel NS. Mitochondria in the regulation of innate and adaptive immunity. Immunity. 2015;42(3):406-417.

Weiss G, Schaible UE. Macrophage defense mechanisms against intracellular bacteria. Immunol Rev. 2015;264(1):182-203.

West AP, Shadel GS, Ghosh S. Mitochondria in innate immune responses. Nat Rev Immunol. 2011b; 11(6): 389-402.

West, AP, Brodsky IE, Rahner C, Woo DK, Erdjument-Bromage H, Tempst P, Walsh MC, Choi Y, Shadel GS, Ghosh S. TLR signalling augments macrophage bactericidal activity through mitochondrial ROS. Nature. 2011a;472(7344):476-80.

Wolf AR, Mootha VK. Functional genomic analysis of human mitocondrial RNA processing. Cell Rep. 2014;7(3):918-31. 
Wynn TA, Chawla A, Pollard JW. Macrophage biology in development, homeostasis and disease. Nature. 2013;496(7446):445-55.

Yamaguchi H, Fujimoto T, Nakamura S, Ohmura K, Mimori T, Matsuda F, Nagata S. Aberrant splicing of the milk fat globule-EGF factor 8 (MFG-E8) gene in human systemic lupus erythematosus. Eur J Immunol. 2010;40(6):1778-85.

Yeung KT, Das S, Zhang J, Lomniczi A, Ojeda SR, Xu CF, Neubert TA, Samuels HH. A novel transcription complex that selectively modulates apoptosis of breast cancer cells through regulation of FASTKD2. Mol Cell Biol. 2011;31(11):2287-98.

Yin Y, Choi SC, Xu Z, Perry DJ, Seay H, Croker BP, Sobel ES, Brusko TM, Morel L. Normalization of CD4+ $T$ cell metabolism reverses lupus. Sci Transl Med. 2015;7(274):274ra18.

Yoo DH, Choi YC, Nam DE, Choi SS, Kim JW, Choi BO, Chung KW. Identification of FASTKD2 compound heterozygous mutations as the underlying cause of autosomal recessive MELAS-like syndrome. Mitochondrion. 2017;35:54-58.

Yoon J, Kim ES, Lee SJ, Park CW, Cha HJ, Hong BH, Choi KY. Apoptosis-related mRNA expression profiles of ovarian cancer cell lines following cisplatin treatment. $J$ Gynecol Oncol. 2010;21(4):255-61.

Yue X, Zhao P, Wu K, Huang J, Zhang W, Wu Y, Liang X, He X. GRIM-19 inhibition induced autophagy through activation of ERK and HIF-1 $\alpha$ not STAT3 in Hela cells. Tumour Biol. 2016;37(7):9789-96.

Zaffran Y, Zhang L, Ellner JJ. Role of CR4 in Mycobacterium tuberculosis-human macrophages binding and signal transduction in the absence of serum. Infect Immun. 1998;66(9):4541-4.

Zhang L, Wang CC. Inflammatory response of macrophages in infection. Hepatobiliary Pancreat Dis Int. 2014;13(2):138-52.

Zhao X, Zmijewski JW, Lorne E, Liu G, Park YJ, Tsuruta T, Abraham E. Activation of AMPK attenuates neutrophil proinflammatory activity and decreases the severity of acute lung injury. Am J Physiol Lung Cell Mol Physiol. 2008;295(3):L497-504.

Zhou G, Myers R, Li Y, Chen Y, Shen X, Fenyk-Melody J, Wu M, Ventre J, Doebber T, Fujii N, Musi N, Hirshman MF, Goodyear LJ, Moller DE. Role of AMP-activated protein kinase in mechanism of metformin action. J Clin Invest. 2001;108(8):116774.

Zhou H, Zhang F, Chen SH, Zhang D, Wilson B, Hong JS, Gao HM. Rotenone activates phagocyte NADPH oxidase by binding to its membrane subunit gp91phox. Free Radic Biol Med. 2012;52(2):303-13.

Zhu J, Vinothkumar KR, Hirst J. Structure of mammalian respiratory complex I. Nature. 2016;536(7616):354-358.

Zmijewski JW, Banerjee S, Bae H, Friggeri A, Lazarowski ER, Abraham E. Exposure to hydrogen peroxide induces oxidation and activation of AMP-activated protein kinase. J Biol Chem. 2010;285(43):33154-64. 
Zmijewski JW, Lorne E, Zhao X, Tsuruta Y, Sha Y, Liu G, Abraham E. Antiinflammatory effects of hydrogen peroxide in neutrophil activation and acute lung injury. Am J Respir Crit Care Med. 2009;15;179(8):694-704.

Zmijewski JW, Lorne E, Zhao X, Tsuruta Y, Sha Y, Liu G, Siegal GP, Abraham E. Mitochondrial respiratory complex I regulates neutrophil activation and severity of lung injury. Am J Respir Crit Care Med. 2008;178(2):168-79.

Zou MH, Kirkpatrick SS, David BJ, Nelson JS, Wiles WG $4^{\text {th }}$, Schlattner U, Neumann D, Brownlee M, Freeman MB, Goldman MH. Activation of the AMP-activated protein kinase by the anti-diabetic drug metformin in vivo. Role of mitochondrial reactive nitrogen species. J Biol Chem. 2004;279(42):43940-51. 


ANEXOS 



\section{ANEXO I. Secuencias}

Secuencias de las clonaciones

- Gen NDUFS4

CAATGAGAACCTGGATCCGCTATGATGTGGAAGACTTCCTGTCAGATTCTC TTCCACATCATAGCTTTTTGAATTCTTCGATTCTGCTTTTTGCTTCTACTGG GTCTCTCTGGTTAGACCAGATCTGAGCCTGGGAGCTCTCTGGCTAACTAG GGAACCCACTGCTTAAGCCTCAATAAAGCTTGCCTTGAGTGCTTCAAGTAG TGTGTGCCCGTCTGTTGTGTGACTCTGGTAACTAGAGATCCCTCAGACCCT TTCAGTCAGTGTGGAAAATCTCTAGCAGTAGTAGTTCATGTCATCTTATTAT TCAGTATTTATAACTTGCAAAGAAATGAATATCAGAGAGTGAGAGGAACTT GTTTATTGCAGCTTATAATGGTTACAAATAAAGCAATAGCATCACAAATTTC ACAAATAAAGCATTTTTTTCACTGCATTCTAGTTGTGGTTTGTCCAAACTCA TCAATGTATCTTATCATGTCTGGCTCTAGCTATCCCGCCCCTAACTCCGCC CATCCCGCCCCTAACTCCGCCCAGTTCCGCCCATTCTCCGCCCCATGGCT GACTAATTTTTTTTATTTATGCAGAGGCCGAGGCCGCCTCGGCCTCTGAGC TATTCCAGAAGTAGTGAGGAGGCTTTTTTGGAGGCCTAGACTTTTGCAGAG ACCAAATTCGTAATCATGTCATAGCTGTTTCCTGTGTGAAATTGTTATCCGC TCACAATTCCACACAACATACGAGCCGGAAGCATAAAGTGTAAAGCCTGG GGTGCCTAATGAGTGAGCTAACTCACATTAATTGCGTTGCGCTCACTGCCC GCTTTCCAGTCGGGAAACCTGTCGTGCCAGCTGCATTAATGAATCGGCCA ACGCGCGGGGAGAGGCGGTTTGCGTATGGGGCGCTCTTCCGCTTCCTCG CTCACTGACTCGCTGCGCTCGGTCGTTCGGCTGCGGCGAGCGGTATCAG CTCACTCAAAGGCGGTAATACGGTTATCCNNCAGAATCNGGGGGATAACG CAGGAAANAACATGNGANCCAAAAGGCCAGCAAAANGGCNAGGAANCCG TAAAAAAGGCCGNGGTTGCTGGNGTTTTTNCANANGGNTCCGCCCCCCCN GGNCNAGCAATCNNAAAAAATCGAACCCTCAANTCAAAAGGGGGNAAAAC CCGANAGGGANTATAAANAAAACNNGGNGNTTTCCCCCNGGAANCTCCCN CGGGGGCTNNTCNGGTTCNNACCCNGCNCTTTACCGGAAAACCNGNTCN CCTTTCCCCNTTNGGGAAGGGGGGGGCNTTTCCNAANCCNCNCGGGGGA GGGATTCCCAATTCGGGGNGGGGNNNTNNCCCCANGGGGGGGGGGNGN AAAAACCCCCGTTTAACCCGANCGGGGNCTTNCNGGAAATTTTNTTGGCC CCCGGGNAANAAANTT

- Gen FASTK

NAAATGNGAACCTGGATCCCTCTGATTGTGCGACGCTACTTCCTGTCAGAT AGCGTCGCACAATCAGAGTTTTTGAATTCTTCGATTCTGCTTTTTGCTTCTA CTGGGTCTCTCTGGTTAGACCAGATCTGAGCCTGGGAGCTCTCTGGCTAA CTAGGGAACCCACTGCTTAAGCCTCAATAAAGCTTGCCTTGAGTGCTTCAA GTAGTGTGTGCCCGTCTGTTGTGTGACTCTGGTAACTAGAGATCCCTCAG ACCCTTTCAGTCAGTGTGGAAAATCTCTAGCAGTAGTAGTTCATGTCATCT TATTATTCAGTATTTATAACTTGCAAAGAAATGAATATCAGAGAGTGAGAGG AACTTGTTTATTGCAGCTTATAATGGTTACAAATAAAGCAATAGCATCACAA 
ATTTCACAAATAAAGCATTTTTTTCACTGCATTCTAGTTGTGGTTTGTCCAA ACTCATCAATGTATCTTATCATGTCTGGCTCTAGCTATCCCGCCCCTAACT CCGCCCATCCCGCCCCTAACTCCGCCCAGTTCCGCCCATTCTCCGCCCCA TGGCTGACTAATTTTTTTTATTTATGCAGAGGCCGAGGCCGCCTCGGCCTC TGAGCTATTCCAGAAGTAGTGAGGAGGCTTTTTTGGAGGCCTAGACTTTTG CAGAGACCAAATTCGTAATCATGTCATAGCTGTTTCCTGTGTGAAATTGTTA TCCGCTCACAATTCCACACAACATACGAGCCGGAAGCATAAAGTGTAAAG CCTGGGGTGCCTAATGAGTGAGCTAACTCACATTAATTGCGTTGCGCTCA CTGCCCGCTTTCCAGTCGGGAAACCTGTCGTGCCAGCTGCATTAATGAAT CGGCCAACGCGCGGGGAGAGGCGGTTTGCGTATTGGGCGCTCTTCCGCT TCCTCGCTCACTGACTCGCTGCGCTCGGTCGTTCGGCTGCGGCGAGCGG TATCAGCTCACTCAAAGGCGGGAANACGGTTATCCCCAAAATCNAGGGGA ANAACGCANGNAAAAACATGNNGAGCAAAAGGNCCGCAAAAGGCCAGGA ACCGTAAAANGGCCGNGTTGCTGGGGTTTTTNCCATAGGCTCCNCCCCCC TGANGNAGCANCCNAAAAATCGACCCCTCAANNTCNNAGGGGGNGAAAC CCGCNGGGGACTTNAAANAAANCCNGGGGTTTCCCCNNGGANCCCCNTG GGGNGCNCCCNGGTTCCAACCNGGGCNCTTACCGGAAAANCNGNCCCCC NTTTTCCCTTNGGNAANGGGGGGCCTTTCCAAAACCCCNCCGGGGANGA NTNNNNTCNGGGGNGGGCCTTCCCCCAANCGGGGGGGGGGNAAAACCC CGNTNNNCNAAANCNGGGCCCTTTCGGGAAANTGTNTTGGANCNNCNGG $\mathrm{AA}$

- Gen NDUFS3

CAANGAGAACCTGGATCCGAGAGTATGTGGCTGAAATCTTCCTGTCAGAA TTTCAGCCACATACTCTCTTTTTGAATTCTTCGATTCTGCTTTTTGCTTCTAC TGGGTCTCTCTGGTTAGACCAGATCTGAGCCTGGGAGCTCTCTGGCTAAC TAGGGAACCCACTGCTTAAGCCTCAATAAAGCTTGCCTTGAGTGCTTCAAG TAGTGTGTGCCCGTCTGTTGTGTGACTCTGGTAACTAGAGATCCCTCAGAC CCTTTCAGTCAGTGTGGAAAATCTCTAGCAGTAGTAGTTCATGTCATCTTAT TATTCAGTATTTATAACTTGCAAAGAAATGAATATCAGAGAGTGAGAGGAA CTTGTTTATTGCAGCTTATAATGGTTACAAATAAAGCAATAGCATCACAAAT TTCACAAATAAAGCATTTTTTTCACTGCATTCTAGTTGTGGTTTGTCCAAAC TCATCAATGTATCTTATCATGTCTGGCTCTAGCTATCCCGCCCCTAACTCC GCCCATCCCGCCCCTAACTCCGCCCAGTTCCGCCCATTCTCCGCCCCATG GCTGACTAATTTTTTTTATTTATGCAGAGGCCGAGGCCGCCTCGGCCTCTG AGCTATTCCAGAAGTAGTGAGGAGGCTTTTTTGGAGGCCTAGACTTTTGCA GAGACCAAATTCGTAATCATGTCATAGCTGTTTCCTGTGTGAAATTGTTATC CGCTCACAATTCCACACAACATACGAGCCGGAAGCATAAAGTGTAAAGCC TGGGGTGCCTAATGAGTGAGCTAACTCACATTAATTGCGTTGCGCTCACTG CCCGCTTTCCAGTCGGGAAACCTGTCGTGCCAGCTGNATTAAAGAATCGG CCAACGNCGCGGGGGAGAGCCGGTTTGNGTATTGGGGNGCTCTTTCCGC TTTCCTCGCTCACTGACTCCGCTGCGCTNGGNCGTTCGGGCTGGGGNNG AGCGGTANCCANNTCNTNCAAAGGNCGGNAANANCTGGTTATCCNCAGGA ATCNGGGGAATAACGCNAGAAAAAACNANGTGAGCNAAAAGGCCNGNNAA AAGGCCCAGGAACCNTAAAAAGGGNCNCGGTGGCNNGGGCGTTTTTCCN 
NNGGCCCCCCCCCCCTGANGNAANNNNCAAAAAANCGNNNNNNCAAGNN CANAGGGGGGGNAAAACCNCNNAGGGANTNNAANAATCCAAGGGTTTTN CCCCNGANAACTCCCNTCNGGGCTNTTCNGNGTCCAACCNTTGGNTTNAC GNAAACCGNGNCCCTTTTCCCCTNGGGAAGGGGGGGCTTTCCAAAGCNN CNGNAAGGANATCAAGTGGGGGNGGGNNTNCCACCAANGGGGTGGGGG GGAAAACCCCNGTTATCCNAANCGGNGCATNTGNGAGAAAATAGNCTATG NGAACCCGGANAAAAAATATTCCCNCNGG 





\section{ANEXO II. Divulgación científica}

Los resultados de esta tesis han dado lugar a las siguientes participaciones en congresos y a la publicación en la revista internacional Journal of Immunology.

Participación en congresos relacionados con la tesis:

- XX Congreso de la Sociedad Española de Enfermedades Infecciosas y Microbiología Clínica (SEIMC), celebrado en Barcelona, del 26 al 28 de mayo de 2016 Presentación oral de la comunicación con título: "Papel de FAST (Fas-activates serine threonine phosphoprotein) en la capacidad fagocítica y bactericida de los macrófagos".

- 27th European Congress of Clinical Microbiology and Infectious Disease (ECCMID), celebrado en Viena, del 22 al 25 de abril de 2017. Presentación póster: "The absence of FASTK protein (Fas-activated serine/threonine kinase) increases the phagocytic capacity both in-vivo and in-vitro of macrophages against E.coli and S.aureus".

\section{Publicación relacionada con la tesis:}

- The mitochondrial isoform of FASTK modulates nonopsonic phagocytosis of bacteria by macrophages via regulation of respiratory complex I. J Immunol 2018; 201:29772985; doi: 10.49/jimmunol.1701075 



\title{
The Mitochondrial Isoform of FASTK Modulates Nonopsonic Phagocytosis of Bacteria by Macrophages via Regulation of Respiratory Complex I
}

\author{
Ana García Del Río,* Aitor Delmiro, ${ }^{\dagger, *}$ Miguel Angel Martín, ${ }^{\dagger, *}$ Roberto Cantalapiedra,* \\ Raquel Carretero,* Carlos Durántez,* Fabiola Menegotto,* María Morán, \\ Pablo Serrano-Lorenzo, ${ }^{\dagger}$ Miguel Angel De la Fuente, ${ }^{\S, \uparrow, 1}$ Antonio Orduña, ${ }^{*, \|, 1}$ and \\ María Simarro $^{\#, 1}$
}

Phagocytosis is a pivotal process by which innate immune cells eliminate bacteria. In this study, we explore novel regulatory mechanisms of phagocytosis driven by the mitochondria. Fas-activated serine/threonine kinase (FASTK) is an RNA-binding protein with two isoforms, one localized to the mitochondria (mitoFASTK) and the other isoform to cytosol and nucleus. The mitoFASTK isoform has been reported to be necessary for the biogenesis of the mitochondrial ND6 mRNA, which encodes an essential subunit of mitochondrial respiratory complex I (CI, NADH:ubiquinone oxidoreductase). This study investigates the role and the mechanisms of action of FASTK in phagocytosis. Macrophages from FASTK $^{-1}$ mice exhibited a marked increase in nonopsonic phagocytosis of bacteria. As expected, CI activity was specifically reduced by almost $50 \%$ in those cells. To explore if decreased CI activity could underlie the phagocytic phenotype, we tested the effect of CI inhibition on phagocytosis. Indeed, treatment with CI inhibitor rotenone or short hairpin RNAs against two CI subunits (NDUFS3 and NDUFS4) resulted in a marked increase in nonopsonic phagocytosis of bacteria. Importantly, re-expression of mitoFASTK in FASTK-depleted macrophages was sufficient to rescue the phagocytic phenotype. In addition, we also report that the decrease in CI activity in FASTK $^{--}$macrophages is associated with an increase in phosphorylation of the energy sensor AMP-activated protein kinase (AMPK) and that its inhibition using Compound $\mathrm{C}$ reverted the phagocytosis phenotype. Taken together, our results clearly demonstrate for the first time, to our knowledge, that mitoFASTK plays a negative regulatory role on nonopsonic phagocytosis of bacteria in macrophages through its action on CI activity. The Journal of Immunology, 2018, 201: 2977-2985.

\section{$\mathrm{F}$} as-activated serine/threonine kinase (FASTK) is the founding member of a novel family of mitochondrial proteins. This family is composed of six members, FASTK and its homologs FASTKD1-5. FASTK was initially proposed to act as a protein kinase (1), but critical active site residues are not conserved within the family, and this activity has been questioned since (2). All members have been found only in vertebrates (2) and were identified as RNA-binding proteins on the basis of mRNA-bound proteome studies $(3,4)$. Through these interactions, members of this family regulate various aspects of mitochondrial RNA metabolism, including mitochondrial RNA granules, RNA processing, degradation, and translation (5-12). FASTK can localize to different cellular compartments due to the presence of an alternative translational initiation site. About $50 \%$ of the endogenous FASTK protein resides in mitochondria (mitoFASTK, $\sim 50 \mathrm{kDa}$ species), whereas the rest distributes between the nucleus and the cytosol (cytoFASTK, $\sim 60 \mathrm{kDa}$ species). FASTKD1-5 are exclusively mitochondrial (2).

In mitochondria, mitoFASTK interacts with ND6 mRNA, which encodes an essential subunit of mitochondrial respiratory complex I (CI, NADH:ubiquinone oxidoreductase). Through this interaction, FASTK protects ND6 mRNA from degradation by the degradosome (12). Accordingly, depletion of FASTK results in the loss of ND6 mRNA and a defect in CI activity (12). In the cytoplasm, cytoFASTK localizes to stress granules and processing bodies and counteracts TIA-1-mediated inhibition of mRNA translation $(13,14)$. In the nucleus, FASTK regulates the alternative splicing of exons flanked by weak splice site recognition sequences.
*Department of Microbiology, University of Valladolid, Valladolid, Spain; ${ }^{\dagger}$ Laboratorio de Enfermedades Mitocondriales y Neuromusculares, Instituto de Investigación del Hospital 12 de Octubre, 28041 Madrid, Spain; "Spanish Network for Biomedical Research in Rare Diseases, U723, 28029 Madrid, Spain; ${ }^{\circledR}$ Department of Cell Biology, Histology and Pharmacology, University of Valladolid, 47005 Valladolid, Spain; 'Institute of Biology and Molecular Genetics, 47003 Valladolid, Spain; "Departamento de Microbiología e Inmunología, Hospital Clínico Universitario, "Departamento de Microbiología e Inmunología, Hospital Clínico Universitario,
47003 Valladolid, Spain; and "Department of Nursing, University of Valladolid, 47005 Valladolid, Spain

${ }^{1}$ M.A.D.1.F., A.O., and M.S., senior authors, contributed equally to this work. ORCIDs: 0000-0001-9791-5191 (A.G.D.R.); 0000-0002-9388-8074 (C.D.); 00000001-6945-6688 (F.M.); 0000-0003-4619-8756 (M.A.D.1.F.); 0000-0001-80131470 (A.O.); 0000-0001-8917-7328 (M.S.)

Received for publication July 25, 2017. Accepted for publication September 10, 2018 .
This work was supported by Consejería de Sanidad Junta de Castilla y León Grants BIO/VA20/15 (to M.S.) and BIO/VA21/15 (to M.A.D.1.F.) and by Roche Diagnostics (to M.S.).

Address correspondence and reprint requests to Dr. María Simarro and Dr. Miguel Angel De la Fuente, Instituto de Biología y Genética Molecular, Universidad de Valladolid y Consejo Superior de Investigaciones Científicas, Calle Sanz y Fores 3 , 47003 Valladolid, Spain. E-mail addresses: maria.simarro.grande@uva.es (M.S.) and mafuente@ibgm.uva.es (M.A.D.1.F.)

The online version of this article contains supplemental material.

Abbreviations used in this article: AMPK $\alpha$, AMP-activated protein kinase $\alpha$; CDS coding sequence; CI, complex I; FASTK, Fas-activated serine/threonine kinase; mitoROS, mitochondrial ROS; PI, phagocytic index; PRR, pattern recognition receptor; RFP, red fluorescent protein; ROS, reactive oxygen species; shRNA, short hairpin RNA; UTR, untranslated region; WT, wild type.

Copyright $(\odot) 2018$ by The American Association of Immunologists, Inc. 0022-1767/18/\$37.50 
Accordingly, FASTK promotes the inclusion of exon IIIb of the fibroblast growth factor receptor 2 (FGFR2) premRNA and exon 6 of Fas premRNA $(15,16)$.

Still very little is known about the role of FASTK in the pathogenesis of human disease. FASTK was found to be overexpressed in PBMCs derived from patients with rheumatoid arthritis, other autoimmune diseases, and asthma $(17,18)$. These data drew our attention and led us to hypothesize that FASTK might play a role in the pathogenesis of the diseases in which its transcript is upregulated. In our attempt to identify the true function of FASTK in immune system and immune-related diseases, we generated FASTK knockout $\left(\right.$ FASTK $\left.^{-1}\right)$ mice. These mice lack the two isoforms of FASTK, mitoFASTK and cytoFASTK, because we deleted the entire gene (19). FASTK $^{-/}$mice were born at the expected Mendelian frequency, survived to maturity, and appeared healthy (19). Our first experiments consisted in inducing experimental allergic asthma and inflammatory arthritis in FASTK $^{-1}$ mice. First, we exposed mice with house dust mite for $3 \mathrm{wk}$ to identify the role of FASTK in the pathogenesis of asthma. The neutrophil recruitment into the lung and alveolar spaces was markedly reduced in $\mathrm{FASTK}^{--}$mice compared with wild type (WT) controls. Similarly, LPS-induced alveolar neutrophil recruitment was markedly reduced in $\mathrm{FASTK}^{-/}$mice (19). This was accompanied by reduced concentrations of various cytokines and chemoattractants in bronchoalveolar lavage fluids (19). Recently, we have also identified FASTK as a driver of joint inflammation in the $\mathrm{K} / \mathrm{BxN}$ model. In this model, arthritis has been shown to be crucially dependent on innate immune cells, and $\mathrm{FASTK}^{-/}$mice developed less severe arthritis compared with WT mice (20). The precise molecular and cellular mechanisms leading to the antiinflammatory phenotype of FASTK $^{-/}$remain to be determined but could reflect additional targets for directed therapy against inflammatory diseases.

One of our current lines of research aims to delineate the role of FASTK and mitochondria in the functions of macrophages in the innate immune response. In this study, we reveal a novel role for FASTK in the regulation of phagocytosis. Macrophages from FASTK $^{-/}$mice exhibited marked increase in nonopsonic phagocytosis of bacteria. The analysis of the molecular mechanisms underlying this phenotype reveals that mitochondria, namely $\mathrm{CI}$ activity, are key in the control of phagocytosis.

\section{Materials and Methods \\ Mice and cells}

WT and $\mathrm{FASTK}^{-/}$mice were derived from the founder stock previously described (19). All procedures and experiments were carried out according to institutional guidelines for the Animal Care and Use Committee at University of Valladolid (Spain). Elicited macrophages were obtained by i.p. injection of $1.5 \mathrm{ml}$ of $3 \%$ sterile Brewer thioglycolate medium $5 \mathrm{~d}$ prior to harvesting. The murine macrophage RAW 264.7 cell line was a gift from Dr. A. Alonso (Instituto de Biología y Genética Molecular, Valladolid). Cell viability was determined by trypan blue exclusion assay or by staining with crystal violet solution ( $0.1 \%$ in PBS) after cell fixation in $4 \%$ paraformaldehyde. Apoptosis was examined using TUNEL assay (Roche). Nuclei were stained with $50 \mathrm{ng} / \mathrm{ml}$ Hoechst 33258 (Sigma-Aldrich). Digital images were captured using a Leica fluorescence microscope (Leica DMI3000 B).

\section{RNA interference}

RAW 264.7 cells were transduced with lentivirus carrying short hairpin RNA (shRNA) against FASTK, NDUFS3, and NDUFS4. The target sequences within the coding regions (coding sequences [CDS]) of the genes of interest were as follows: mouse FASTK (RefSeq accession number NM 023229, https://www.ncbi.nlm.nih.gov/nuccore/NM_023229) 5'-GTCAGCTCATCATCCGAAA-3', mouse NDUFS3 (RefSeq accession number NM_026688, https://www.ncbi.nlm.nih.gov/nucleotide/NM_026688) 5'-GAGAGTATGTGGCTGAAAT-3' and mouse NDUFS4 (RefSeq accession number NM_010887.2, https://www.ncbi.nlm.nih.gov/nuccore/ NM_010887.2) 5'-GCTATGATGTGGAAGAGAA-3'. The target sequence within the $5^{\prime}$ untranslated region (5'UTR) of FASTK (RefSeq accession number NM_023229. https://www.ncbi.nlm.nih.gov/nuccore/ NM_023229) was as follows: 5'-GCTGGACTGCGATTGGCGTCT-3'. Inserts were prepared by annealing shRNA oligonucleotides containing two complementary target sequences linked by a short loop and then were cloned into the BamHI/EcoRI sites of the shRNA lentiviral vector pGreenPuro, all according to vector manufacturer's instructions (System Biosciences). The resultant plasmids were screened for insert by PCR and then sequenced with the following primers (all according to vector manufacturer's instructions): forward 5'-AATGTCTTTGGATTTGGGAATCTTAT-3' and reverse 5'-TGGTCTAACCAGAGAGACCCAGTA-3'. Lentiviral stocks were produced by transient cotransfection into the human 293FT cell line (Thermo Fisher Scientific) with the appropriate lentiviral expression plasmid and lentiviral helper plasmids (psPAX2 packaging vector and $\mathrm{pMD} 2$.G envelope-encoding vector) using TransIT-X2 (Mirus Bio). psPAX2 (Addgene plasmid no. 12260) and pMD2.G (Addgene plasmid no. 12259) were gifts from D. Trono. RAW 264.7 cells were then transduced and selected with $7 \mu \mathrm{g} / \mathrm{ml}$ puromycin for at least $2 \mathrm{wk}$ before assaying. Gene silencing efficiency was assessed by quantitative RT-PCR using SYBR Green (Thermo Fisher Scientific), and it was of $74 \%$ for shNDUFS3 CDS, $67 \%$ for shNDUFS 4 CDS, $85 \%$ for shFASTK CDS, and $78 \%$ for shFASTK 5 ' UTR. $\beta$-actin was used as a housekeeping gene. The primers used for quantitative RT-PCR were as follows: mouse FASTK, 5' CTGGAAGCCATTGCTCATTTC-3' (forward) and 5'-CTCTCAAGGCAGGGCATAAA-3' (reverse); mouse NDUFS3, 5'-GATGAGCTGACACCCATTGA-3' (forward) and 5'-ATGTCCCTCGAAGCCATAATC-3' (reverse); mouse NDUFS4, 5' -TCTGACCTTCAGTGCCAAAG-3' (forward) and 5'-GTAGCCAGCTCCAACCTATTT-3' (reverse); mouse $\beta$-actin, 5'-GACATGGAGAAGATCTGGCA-3' (forward) and 5'-GGTCTCAAACATGATCTGGGT-3' (reverse). RAW 264.7 cells stably expressing shRNA against the $5^{\prime} \mathrm{UTR}$ of mouse FASTK were used for rescue experiments. These cells were transfected with constructs encoding for red fluorescent protein (RFP) alone (Clontech), C-terminal RFP-tagged WT human FASTK, or human FASTK deletion mutant starting at the internal methionine at position $35(\Delta 1-34)$. RFP-tagged FASTK constructs were a generous gift of Dr. N. Kedersha and Dr. P. Anderson (Harvard University). Transfected cells were selected with $1 \mathrm{mg} / \mathrm{ml} \mathrm{G} 418$ (SigmaAldrich), and the expression of RFP-tagged constructs was assessed using fluorescence microscopy and Western blotting.

\section{Bacteria and other phagocytic particles}

Escherichia coli strain DH5- $\alpha$ was from Invitrogen (Thermo Fisher Scientific). Staphylococcus aureus Cowan 1 strain was from American Type Culture Collection (ATCC 12598). Recombinant E. coli (DH5- $\alpha$ ) bacteria expressing GFP were obtained by introducing a pUC-based plasmid carrying a GFP gene (ampicillin-resistant) into chemically competent bacteria. GFP-expressing S. aureus were a gift from Dr. A. Abadía Molina (University of Granada, Spain). When necessary, bacteria were labeled with fluorochromes FITC (Sigma-Aldrich) or tetramethylrhodamine-5(and-6)-isothiocyanate (Thermo Fisher Scientific). Briefly, heat-killed bacteria $\left(80^{\circ} \mathrm{C}, 15 \mathrm{~min}\right)$ were incubated with a $0.1 \mathrm{mg} / \mathrm{ml}$ solution of fluorochrome at $37^{\circ} \mathrm{C}$ for $30 \mathrm{~min}$ and washed three times with PBS prior to use. Zymosan particles were from Sigma-Aldrich and were labeled as described for bacteria. Polystyrene latex beads were $2.0 \mu \mathrm{m}$ in diameter and yellow-green fluorescent (Molecular Probes, Thermo Fisher Scientific). For the preparation of serum-opsonized particles, fluorochromelabeled, heat-killed bacteria, zymosan, and latex beads were incubated in $50 \%$ mouse serum in $\mathrm{PBS}$ at $37^{\circ} \mathrm{C}$ for $30 \mathrm{~min}$ and then washed to remove unbound serum. As to Ig-opsonized particles, the following reagents were purchased from Molecular Probes (Thermo Fisher Scientific): zymosan A bioparticles and E. coli (K-12 strain) bioparticles, both Texas Red conjugates, S. aureus (Wood strain without protein A) bioparticles fluorescein conjugate, and purified rabbit polyclonal IgG Abs specific to each of the three bioparticles. IgG-opsonized polystyrene latex beads were prepared by incubation with $3 \mathrm{mg} / \mathrm{ml}$ rabbit IgG (Sigma-Aldrich) in PBS for $30 \mathrm{~min}$ at $37^{\circ} \mathrm{C}$ followed by extensive washing with PBS.

\section{Phagocytosis assays}

Macrophages $\left(5 \times 10^{5}\right)$ were seeded on 12 -mm coverslips in 24-well plates and were grown overnight. To remove all traces of seric proteins, the cells were washed twice in serum/antibiotics-free DMEM medium supplemented with GlutaMAX and were preincubated at $37^{\circ} \mathrm{C}$ for $30 \mathrm{~min}$. All further incubations were performed in the absence of serum. Nonopsonized fluorochrome-labeled bacteria, zymosan, or latex beads were added to macrophages at a 100:1 ratio for $30 \mathrm{~min}$ at $37^{\circ} \mathrm{C}$. Where indicated, Ig- or 
serum-opsonized particles were used. After incubation periods, macrophages were washed three times with cold PBS, and extracellular FITC-labeled bacteria were quenched with a 60 -s wash in trypan blue $(0.2 \mathrm{mg} / \mathrm{ml})$. Macrophages were fixed with $4 \%$ paraformaldehyde. Phagocytosed fluorochrome-labeled bacteria were counted under a confocal fluorescence microscope (the characteristics of the equipment are detailed in this Materials and Methods section under Evaluation of phagolysosomal fusion). Phagocytic index (PI) was calculated as the percentage of positive macrophages $\times$ the mean number of either bacteria or FITC-labeled latex beads (Sigma-Aldrich) of positive macrophage. The fluorescence of the cells was also determined by flow cytometry using a Beckman Coulter Gallios (Beckman Coulter). In this case, the cells were plated in 12 -well plates $\left(1 \times 10^{6}\right.$ macrophages per well). The phagocytosis test was done in a similar manner to that described for 24-well plates.

\section{Bacterial killing and oxidative burst assays}

Bactericidal activity was measured using a gentamicin protection assay. Briefly, elicited peritoneal macrophages and RAW 264.7 cells were plated into 24 -well plates at a density of $5 \times 10^{5}$ cells per well (three wells per experimental condition) and allowed to adhere overnight. To remove al traces of seric proteins, the cells were washed twice in serum/antibioticsfree DMEM supplemented with GlutaMAX and were preincubated at $37^{\circ} \mathrm{C}$ for $30 \mathrm{~min}$. All further incubations were performed in the absence of serum. Nonopsonized bacteria were added to cells at a multiplicity of infection of 50 . After $15 \mathrm{~min}$ of incubation at $37^{\circ} \mathrm{C}$ and $5 \% \mathrm{CO}_{2}$, the nonadherent extracellular bacteria were removed by washing with PBS, and the adherent extracellular bacteria were subsequently killed by the addition of serum-free DMEM containing gentamicin $(100 \mu \mathrm{g} / \mathrm{ml})$. At time $0^{\prime}$ (which corresponds to $15 \mathrm{~min}$ after addition of gentamicin) and subsequent time points, cells were washed three times with PBS and lysed with $1 \mathrm{ml}$ of sterile distilled water. Serial dilutions of cellular lysates were plated onto Luria-Bertani agar plates, and the number of CFUs was determined after 24 -h growth at $37^{\circ} \mathrm{C}$. The percentage of killed bacteria was calculated as follows: \% killing $=100-[$ (no. of CFU at time X/no. of CFU at time $\left.\left.0^{\prime}\right) \times 100\right]$.

The oxidative burst in macrophages was triggered by exposure to bacteria (ratio of bacteria to cells was 100:1) and detected using a luminol-based bioassay. Chemiluminescence was detected in 323- $\mu$ l samples that contained $2 \times 10^{5}$ macrophages, $200 \mu \mathrm{M}$ luminol (Thermo Fisher Scientific), and $16 \mathrm{U}$ of HRP (Sigma-Aldrich) in a microplate luminometer (Appliskan; Thermo Fisher Scientific).

\section{Evaluation of phagolysosomal fusion}

We monitored the kinetics of phagolysosomal fusion under experimental conditions similar to those of the gentamicin protection assay described above. Elicited peritoneal macrophages $\left(5 \times 10^{5}\right)$ were seeded on $12-\mathrm{mm}$ coverslips in 24-well plates and were grown overnight. Cells were switched to serum/antibiotics-free conditions and pulsed for $15 \mathrm{~min}$ with nonopsonized GFP-expressing E. coli (at a multiplicity of infection of 50). Cells were chased for different times in the presence of gentamicin (at $100 \mu \mathrm{g} / \mathrm{ml}$ ) and were loaded with Lysotracker Red DND-99 (500 nM) for the last $5 \mathrm{~min}$ of each chase period. Time $0^{\prime}$ corresponds to $15 \mathrm{~min}$ after addition of gentamicin. Before fixation, coverslips were washed three times in PBS and then fixed in $4 \%$ paraformaldehyde for $15 \mathrm{~min}$ at room temperature. Nuclei were stained with $5 \mu / \mathrm{ml}$ Hoechst 33342, and after washing with PBS, the coverslips were mounted and viewed. Confocal images were obtained with a $63 \times$ oil immersion objective (HCX PL Apo CS NA = 1.4; Leica) attached to a confocal DMI 6000B microscope with a TCS SP5 confocal system (Leica) equipped with acousto-optical beam splitter and acousto-optic tunable filter systems. We obtained confocal sections under constant conditions to minimize image acquisition variation. Images were stored as $1024 \times 1024$ pixels and 8-bit TIFF files. The colocalization of E. coli (green) with lysotracker (red) was enumerated. At least 20 fields were examined per slide, and representative pictures were taken.

\section{Flow cytometry}

Abs were purchased from the following sources: FITC-conjugated antiCD80 (16-10A1), FITC-conjugated anti-CD86 (GL1), FITC-conjugated anti-CD40 (3/23), FITC-conjugated anti-CD38 (90/CD38), FITCconjugated anti-CD14 (rmC5-3), FITC-conjugated anti-CD206 (19.2), and APC-conjugated CD11b (M1/70) were purchased from BD Biosciences. PE-conjugated F4/80 (Cl:A3-1) was purchased from AbD Serotec. Anti-TLR 2 (6C2) and anti-TLR4 (MTS510) were purchased from eBioscience (Thermo Fisher Scientific), and PE-conjugated anti-rat Ig was obtained from BD Biosciences. When indicated, cells were labeled with $2.5 \mu \mathrm{M}$ MitoSOX Red indicator (Molecular Probes,
Thermo Fisher Scientific). In all cases, the fluorescence of the cells was determined by flow cytometry using a Beckman Coulter Gallios (Beckman Coulter). Data were analyzed using either FlowJo software (Tree Star) or Kaluza software (Beckman Coulter). Fluorescence intensity was plotted on a log scale. The number of cells acquired for each sample depended on the subpopulation studied, and at least 10,000 cells were analyzed.

\section{Western blot analysis}

Protein was extracted by RIPA buffer (20 mM tris, pH 7.4; $1 \%$ NP-40; $1 \%$ sodium deoxycholate; $0.1 \%$ SDS; $150 \mathrm{mM} \mathrm{NaCl} ; 1 \mathrm{mM}$ EDTA) containing a mixture of protease inhibitors from Sigma-Aldrich (catalog no. P8340) and $50 \mathrm{mM}$ sodium fluoride. Twenty-microgram protein samples separated by SDS-PAGE and transferred to PVDF membranes were probed with Abs against AMP-activated protein kinase $\alpha$ (AMPK $\alpha$, catalog no. 2532; Cell Signaling Technology), phospho-AMPK $\alpha$ Thr172 (catalog no. 2531; Cell Signaling Technology), RFP (5F8; Chromotek), and actin (AC-40; SigmaAldrich) following the manufacturer's instructions. Band intensities were determined by densitometric analysis using ImageJ software.

\section{Respiratory chain activity}

Respiratory activity of complexes I, II, III, and IV were performed in a Shimadzu UV-1800 Spectrophotometer as previously described (21) with slight modifications.

\section{Statistics}

All analyses were performed using Prism software (GraphPad). Data are expressed as mean \pm SEM and were analyzed by using either one-way ANOVA with Bonferroni correction, the unpaired Student $t$ test, or Mann-Whitney $U$ test as appropriate. In all graphs, $* p<0.05, * * p<0.01, * * * p<0.001$.

\section{Results}

The absence of FASTK causes an increase in phagocytosis by macrophages

To further explore the role of FASTK in innate immune system, we assessed whether the absence of this protein impacted one of the most important functions of the macrophages, which is their ability to phagocytose and kill bacteria. We took advantage of the FASTK $^{-1-}$ mice we had previously generated (19). FASTK $^{-1-}$ mice do not show defective development of the immune system (19). In this study, we used thioglycolate-elicited macrophages, and we again excluded the possibility of developmental defects because WT and FASTK ${ }^{-/}$macrophages had no difference in their expression of cell surface markers (Supplemental Fig. 1A).

Phagocytosis was performed using both nonopsonized and opsonized phagocytic particles, and the incubation period was 30 min in all the experiments. As shown in Fig. 1A, the PI for uptake of nonopsonized E. coli was significantly increased in FASTK $^{-1-}$ macrophages compared with WT controls. Similarly, although to a lesser extent, the PI for nonopsonized S. aureus was markedly increased. Almost identical results were obtained when the incubation period was only $15 \mathrm{~min}$ (Supplemental Fig. 1B). No differences were observed at $4^{\circ} \mathrm{C}$ (Supplemental Fig. 1C), indicating that internalization, rather than binding, was affected. Phagocytosis of FASTK ${ }^{-/-}$macrophages was not globally increased, as the phagocytosis of nonopsonized zymosan and latex beads was similar to that of WT (Fig. 1A top panel). We next explored the phagocytosis of Ig- and serum-opsonized bacteria, zymosan, and latex beads (Fig. 1A bottom panel and Supplemental Fig. 1D). Opsonic phagocytosis was unaltered in FASTK $^{-1}$ macrophages. Altogether, these data indicate that FASTK selectively modulates the nonopsonic phagocytosis of bacteria.

We next examined the bactericidal activity of FASTK $^{-1-}$ macrophages using the in vitro gentamicin protection assay in serum-free conditions to eliminate the contributions of $\mathrm{Fc}$ and/or complement receptors (Fig. 1B). Nonopsonized bacteria were added to cells for $15 \mathrm{~min}$. The nonadherent extracellular bacteria were removed by washing, and the adherent extracellular bacteria subsequently killed with gentamicin $(100 \mu \mathrm{g} / \mathrm{ml})$ for $15 \mathrm{~min}$. 
A

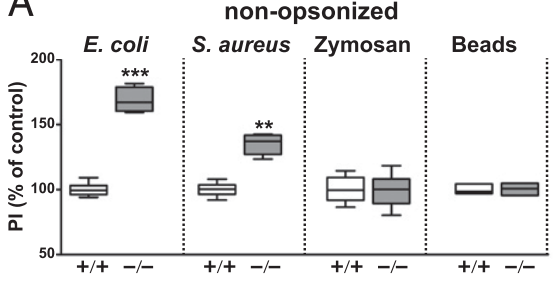

Ig-opsonized

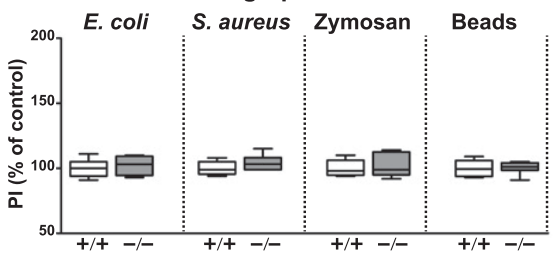

B
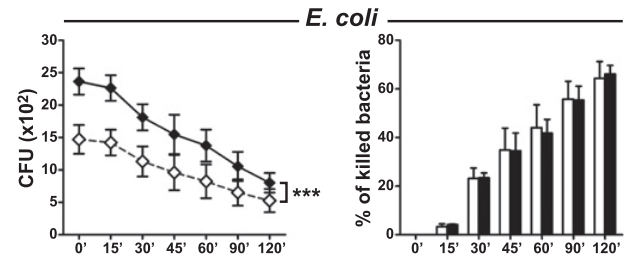

$\square \diamond+/+\quad \square \diamond-/-$

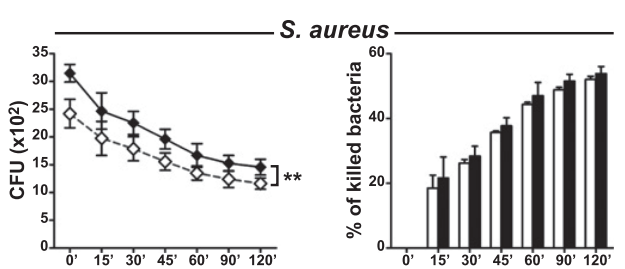

FIGURE 1. Phagocytosis and survival of bacteria in WT and FASTK ${ }^{-/}$macrophages. (A) Macrophages were incubated with either Ig-opsonized or nonopsonized bacteria, zymosan, and inert latex beads for $30 \mathrm{~min}$. PI values were normalized to average PI of control cells. Data are represented as box and whiskers plots ( $n=5$ independent experiments). (B) Bactericidal activity was measured by gentamicin protection assay in serum-free conditions. Numbers of CFU per well of $E$. coli and $S$. aureus recovered at the indicated time points are represented in the left panels. The right panels represent the percentage of killed bacteria at different time points compared with time $0^{\prime}$. The values in the graphs represent means \pm SEM ( $n=3$ independent experiments). $* * p<0.01, * * * p<0.001$.

At the indicated time points, intracellular CFUs were enumerated to monitor bacterial burden (Fig. 1B, left panel). As we indicated in the Materials and Methods section, time $0^{\prime}$ corresponds to 15 min after addition of gentamicin and $30 \mathrm{~min}$ after the beginning of the exposure to bacteria. As shown in the left panel of Fig. 1B, the number of surviving $E$. coli and $S$. aureus was significantly higher in FASTK ${ }^{-1}$ macrophages than in WT controls at all time points. This result was expected, as the number of bacteria recovered from the gentamicin protection assay at early points correlates well with the phagocytic capacity. Based on the numbers of surviving bacteria, we next calculated the percentage of killed intracellular bacteria as an approach to quantify the intracellular bactericidal activity (Fig. 1B, right panel). The graphs show that the bactericidal activity is unaltered in $\mathrm{FASTK}^{-1-}$ macrophages at all time points. At the end of the time course, both types of macrophages had eliminated $\sim 60 \%$ of the ingested E. coli and $\sim 50 \%$ of the ingested $S$. aureus. Production of reactive oxygen species (ROS) by the NADPH oxidase is essential for efficient bacterial killing by macrophages and neutrophils. As shown in Supplemental Fig. 2A, FASTK ${ }^{-/-}$macrophages' ability to produce ROS in response to bacteria was unaltered as measured in a luminol-based assay that correlated well with the intact killing activity in the absence of FASTK. Phagocytosed bacteria are contained within phagosomes that mature into phagolysosomes. LysoTracker selectively labels late endosomes and lysosomes and colocalizes with LAMP $(22,23)$. We monitored the maturation of phagosomes containing GFP-expressing $E$. coli by their ability to colocalize with Lysotracker Red over time under confocal fluorescence microscopy (Supplemental Fig. 2B). Pulse-chase incubation times corresponded to those of the gentamicin protection assay described above. The percentages of colocalization between these two colored markers were similar in WT and FASTK $^{-1}$ macrophages at all time points. Colocalization increased gradually over time and reached $\sim 50 \%$ at time $120^{\prime}$ in both types of cells. Unaltered kinetics of the maturation of phagosomes containing E. coli in FASTK $^{-/}$macrophages were consistent with the above explained bacterial killing assay results.

Altogether, these results demonstrate that FASTK modulates the phagocytic capacity of macrophages toward E. coli and S. aureus but not their bactericidal activity.

\section{The absence of FASTK results in a defective CI activity}

FASTK can be found in the nucleus, processing bodies, and stress granules in the cytoplasm, and mitochondrial RNA granules. The mitoFASTK isoform has been the best characterized. It is synthesized from an alternative downstream translation initiation site and lacks the first 34 aa present at the N-terminus, exposing a mitochondrial targeting signal. mitoFASTK is essential for mitochondrial ND6 mRNA biogenesis. Thus, in the absence of mitoFASTK, the ND6 mRNA is undetectable, resulting in a $60 \%$ decrease in CI activity in the skeletal and cardiac muscles of FASTK $^{-1-}$ mice (12). To explore the molecular mechanisms involved in the phagocytic phenotype, we first studied whether the activity of CI was also affected in FASTK $^{-/}$peritoneal macrophages. As shown in Fig. 2, we observed a significant decrease of CI activity by up to $45 \%$ in FASTK $^{-1-}$ macrophages, whereas the activity of other complexes was not significantly altered. The decrease in CI has also been linked to other processes that resemble phagocytosis: efferocytosis by microglia and autophagy in HeLa cells $(24,25)$. We thus hypothesized that CI-decreased activity was responsible for the bacterial phagocytic phenotype in FASTK $^{-/}$macrophages.

The inhibition of mitochondrial CI activity causes an increase in the phagocytosis of bacteria by macrophages

To determine whether decreased CI activity could underlie increased phagocytosis of bacteria in $\mathrm{FASTK}^{-/-}$macrophages, we tested the role of $\mathrm{CI}$ in macrophage phagocytosis by specifically inhibiting CI activity using either rotenone or shRNA against of NDUFS3 and NDUFS4. Rotenone has been reported to be a specific and potent inhibitor of CI. A rotenone dose-response curve on WT peritoneal macrophages demonstrated that $30 \mathrm{nM}$ rotenone produced a similar inhibition of CI activity $(\sim 50 \%$ decrease) to that observed in FASTK $^{-/}$macrophages (Supplemental Fig. 3A). For this reason, we used $30 \mathrm{nM}$ rotenone in this study. Similarly, RAW 264.7 cells also showed $50 \%$ inhibition of CI activity when treated with $30 \mathrm{nM}$ rotenone (data not shown).

WT peritoneal macrophages were incubated with $30 \mathrm{nM}$ rotenone for $24 \mathrm{~h}$ before assessment of bacterial phagocytosis. Rotenone at $30 \mathrm{nM}$ did not result in any toxicity as assessed by the trypan blue exclusion or TUNEL assays (Supplemental Fig. 3B). 
Complexes activities (corrected for Citrate Synthase)

\begin{tabular}{|c|c|c|c|}
\hline & Wild type & FASTK $^{-I-}$ & \\
\hline Complex I & $28.9 \pm 4.49(n=4)$ & $17.0 \pm 3.46(n=4)$ & $p=0.03$ \\
\hline Complex II & $49.5 \pm 13.54(n=3)$ & $52.0 \pm 13.04(n=3)$ & ns \\
\hline Complex III & $188.9 \pm 6.68(n=3)$ & $192.9 \pm 5.47(n=3)$ & ns \\
\hline Complex IV & $181.1 \pm 13.5(n=3)$ & $197.4 \pm 10.5(n=3)$ & ns \\
\hline
\end{tabular}

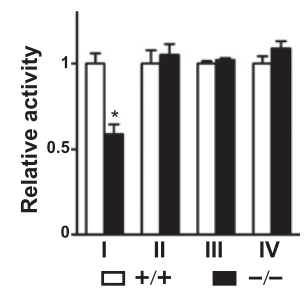

FIGURE 2. Activity of respiratory complexes in FASTK $^{-/-}$macrophages. The specific activities of CI (NADH:ubiquinone oxidoreductase), CII (succinate dehydrogenase), CIII (cytochrome c reductase), and CIV (cytochrome c oxidase) were measured in cell lysates, normalized to citrate synthase (CS) activity, and expressed as $(\mathrm{nmol} / \mathrm{min} / \mathrm{mg}$ protein $) /(\mathrm{sp}$. act. of $\mathrm{CS}) \times 100$. Data are presented as means \pm SEM. The number of independent experiments and the $p$ value are indicated. In the right panel, relative enzymatic activities of respiratory chain complexes in WT and FASTK ${ }^{-1}$ macrophages. ${ }^{*} p<0.05$.

Interestingly, treatment with rotenone resulted in an increase in the phagocytosis of nonopsonized bacteria after $30 \mathrm{~min}$ incubation comparable to the increase observed in $\mathrm{FASTK}^{-/}$macrophages (Fig. 3A). As in FASTK $^{--}$macrophages, the PI of nonopsonized zymosan and latex beads remained unchanged by rotenone treatment (Fig. 3A). Nearly identical results were obtained when the incubation period was only $15 \mathrm{~min}$ (Supplemental Fig. 3C). Importantly, rotenone pretreatment did not alter the killing activity of WT macrophages at $120^{\prime} / \mathrm{T} 2$ time point (Fig. 3B) nor the ability to generate ROS (Supplemental Fig. 2A). The increased intracellular $\mathrm{CFU}$ numbers in macrophages pretreated with rotenone correlates well with increased bacterial uptake.

To further confirm the role of CI in the regulation of bacterial phagocytosis, we generated two macrophage models of CI deficiency by silencing two of its subunits: NDUFS3 and NDUFS4 (Fig. 4A). As a catalytic subunit, NDUFS3 has been shown to play a vital role in the proper assembly of CI (26). NDUFS4 is not directly involved in electron transport but plays a role in the stability of the entire complex (27). We stably depleted NDUFS3 and NDUFS4 in the murine macrophage RAW 264.7 cell line using lentiviral-based shRNA constructs. RAW 264.7 cells expressing shRNA against FASTK CDS or pretreated with rotenone $(30 \mathrm{nM})$ were used as positive controls. As shown in Fig. 4B, NDUFS3 and NDUFS4 depletion resulted in an increase in the PIs of nonopsonized bacteria PI, whereas PI of nonopsonized zymosan or latex beads remained unchanged. Finally, we explored the bactericidal activity in these stable cell lines. Depletion of NDUFS3 and NDUFS4 did not alter the killing activity of RAW 264.7 cells. It is noteworthy that parental RAW 264.7 cells exhibited increased bactericidal activity against $S$. aureus as compared with WT peritoneal macrophages. At 120'/T2 time point, the percentage of killed S. aureus was $\sim 70 \%$ in parental RAW 264.7 cells and $\sim 50 \%$ in WT peritoneal macrophages. In addition, we observed that silencing of NDUFS3, NDUFS4, and FASTK as well as pretreatment with rotenone caused a small, nonsignificant increase in the bactericidal activity of RAW 264.7 cells against $S$. aureus.

In conclusion, the inhibition of CI activity using either rotenone or shRNA against NDUFS3 and NDUFS4 induced similar effects on macrophages as those induced by the deletion or depletion of FASTK. These observations suggest that mitoFASTK is responsible for the phenotype and functions as a negative regulator of phagocytosis by targeting CI.

Re-expression of FASTK mitochondrial isoform is sufficient to rescue the phagocytic phenotype in FASTK-depleted RAW 264.7 cells

To test that the mitochondrial isoform of FASTK is indeed responsible for the phagocytic phenotype, we performed rescue experiments. First, we stably depleted FASTK in RAW 264.7 cells with lentiviral-based shRNA construct targeting the 5'UTR of FASTK. We used an shRNA that targets the 5'UTR because the expression can be easily rescued by vectors expressing the coding region of FASTK. FASTK-depleted cells were then stably transfected with WT FASTK, which contains the two translation initiation sites and encodes both mitoFASTK and cytoFASTK and a mutant FASTK that starts at the internal methionine at position 35 $(\Delta 1-34)$ and only encodes mitoFASTK (Fig. 5A). Both constructs carried RFP at their $\mathrm{C}$ terminus. As control, we also generated FASTK-depleted RAW 264.7 cells expressing RFP alone. Expression was evaluated by fluorescence microscopy (data not shown) and Western blot with anti-RFP Ab (Fig. 5B). As shown in Fig. 5C, the re-expression of FASTK $\Delta 1-34$ alone was able to rescue CI activity and the phagocytic phenotype of FASTKdepleted cells. Again, phagocytosis experiments were performed with nonopsonized $E$. coli and $S$. aureus. These results demonstrate that mitoFASTK is a negative regulator of nonopsonic phagocytosis of bacteria by macrophages via regulation of respiratory $\mathrm{CI}$.

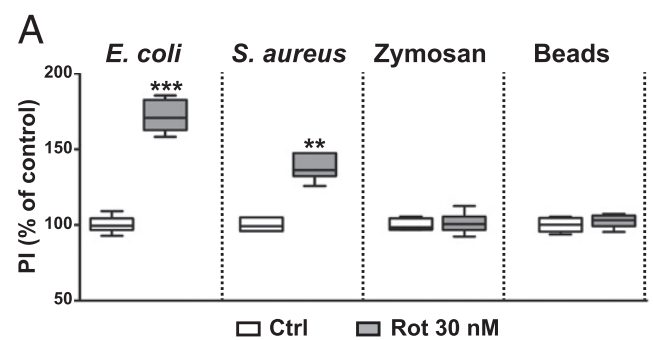

B

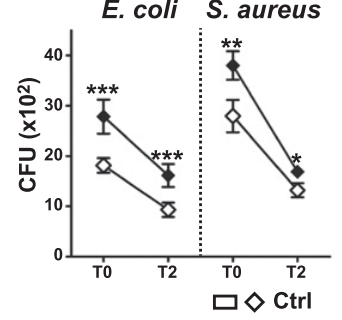

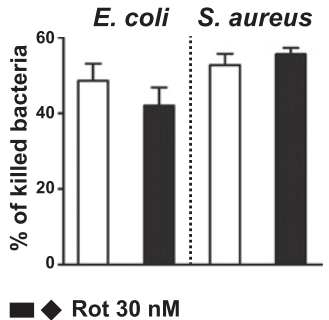

FIGURE 3. Phagocytosis and survival of bacteria in rotenone-treated WT macrophages. (A) Thioglycolate-elicited peritoneal macrophages were treated with rotenone $(30 \mathrm{nM})$ for $24 \mathrm{~h}$, then incubated with nonopsonized bacteria, zymosan, and inert latex beads for 30 min. PI values were normalized to average PI of control cells. Data are represented as box and whiskers plots ( $n=6$ independent experiments). (B) Bactericidal activity of rotenone-treated and -untreated WT macrophages was assessed by gentamicin protection assay in serum-free conditions. Numbers of CFU per well of $E$. coli and $S$. aureus recovered at T0 (time $0^{\prime}$ ) and T2 (time 120') are represented. The right panels represent the percentage of killed bacteria at T2 compared with T0 for each treatment condition. Means \pm SEM are shown $(n=4$ independent experiments). $* p<0.05, * * p<0.01, * * * p<0.001$. 


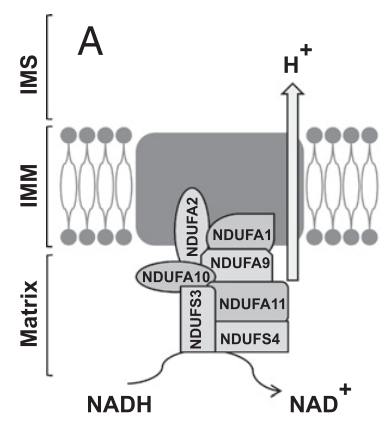

B

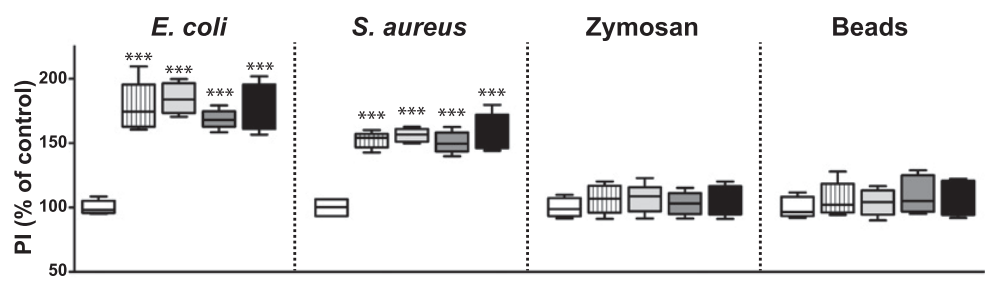

$\square \diamond \operatorname{Ctrl} \square$ 四 shNDUFS3 $\square \diamond$ shNDUFS4 $\square \diamond \operatorname{shFASTK~} \square \diamond \operatorname{Rot} 30 \mathrm{nM}$
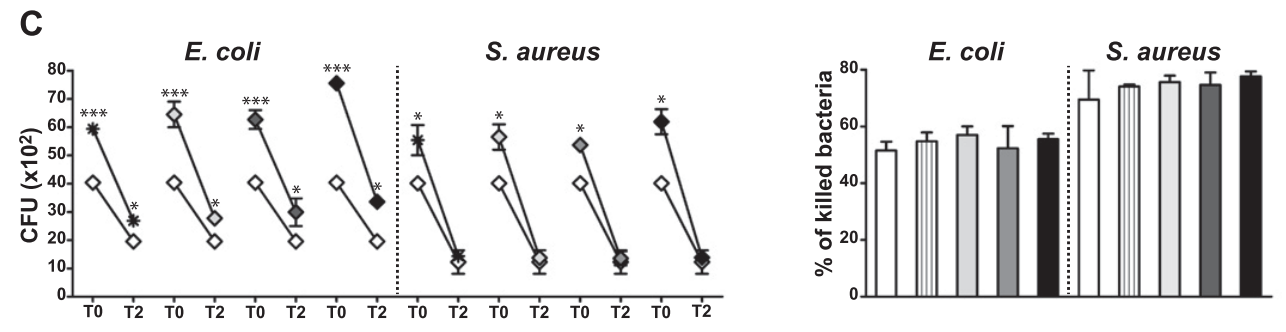

FIGURE 4. Effects of the silencing of CI subunits on phagocytosis and killing of bacteria. (A) Schematic representation of the mitochondrial CI, NADH: ubiquinone oxidoreductase complex. Mammalian CI contains 44 different subunits; some of them are represented. (B) The activity of CI in RAW 264.7 cells was inhibited by treatment with rotenone or the lentiviral-mediated stable expression of shRNA constructs directed against the CDS of NDUFS4 or NDUFS3. Cells expressing shRNA against FASTK CDS were also included in the experiments. Cells were then incubated with nonopsonized bacteria, zymosan, and inert latex beads for $30 \mathrm{~min}$. PI values were normalized to average PI of control cells (RAW 264.7 cells expressing nontargeting shRNA). Data are represented as box and whiskers plots $\left(n=3\right.$ independent experiments). (C) T0 (time $\left.0^{\prime}\right)$ and T2 (time $\left.120^{\prime}\right)$ in the gentamicin protection assay done in serum-free conditions are shown. Graphs represent numbers of CFU per well of E. coli and $S$. aureus. The right panels represent the percentage of killed bacteria at T2 compared with T0 for each stable RAW 264.7 cell line. Means \pm SEM are shown $\left(n=4\right.$ independent experiments). ${ }^{*} p<0.05, * * * p<0.001$.

\section{AMPK $\alpha$ plays a key role in FASTK-mediated modulation of bacterial phagocytosis}

CI dysfunction triggers transient and sustained changes in metabolism and is accompanied by the phosphorylation of AMPK $\alpha$, a crucial cellular energy sensor. Glucose supply and AMPK $\alpha$ subunit have been proven to be crucial for cell survival during CI dysfunction (28). AMPK $\alpha$ has also been reported to enhance the phagocytic ability of macrophages and neutrophils (29). We thus hypothesized that a decrease in CI activity augments the phagocytosis of bacteria by macrophages via activation of AMPK.

We first examined the phosphorylation status of AMPK $\alpha$ (threonine 172) and the total AMPK levels in WT and $\mathrm{FASTK}^{-/}$ peritoneal macrophages unexposed or exposed to bacteria $E$. coli and $S$. aureus. Interestingly, the basal phosphorylation level of AMPK $\alpha$ was increased $\sim 2$-fold in FASTK $^{-/}$macrophages over WT cells (Fig. 6A, 6B). Exposure to bacteria led to a significant increase in $\mathrm{AMPK} \alpha$ phosphorylation in WT macrophages. We also observed an increase in phosphorylated AMPK $\alpha$ in $\mathrm{FASTK}^{-/}$ macrophages upon exposure to bacteria, but in this case, the increase over already increased baseline levels was not found to be significant. AICAR was used as positive control for AMPK phosphorylation. Total AMPK levels remained unchanged (Fig. 6A).

To further explore the role of AMPK activation in FASTKmediated modulation of phagocytosis, we examined the effects of Compound C AMPK inhibitor on the phagocytic phenotype of FASTK $^{-/}$macrophages. Cells were pretreated with $10 \mu \mathrm{M}$ of Compound $\mathrm{C}$ prior to phagocytosis assays. As shown in Fig. 6C, treatment with Compound $\mathrm{C}$ reverted the phagocytic phenotype induced by the absence of FASTK in murine primary macrophages. Very similar results were obtained using FASTK-silenced RAW 264.7 cells (Supplemental Fig. 4A). These results demonstrate that AMPK is a key player in the modulatory role of FASTK in phagocytosis

\section{Discussion}

The present work reveals a novel role for mitoFASTK in the regulation of nonopsonic phagocytosis of bacteria by macrophages. The molecular mechanisms responsible for this phenotype are the decrease in CI activity and AMPK activation.

Although opsonic phagocytosis is more effective, nonopsonic phagocytosis is a crucial mechanism for host control during the initial stages of infection and in anatomic spaces where opsonins may be limiting, such as the alveolar space (30). Different pattern recognition receptors (PRRs) have been described to be involved in the binding and capture of nonopsonized microorganisms, which include transmembrane proteins such as the TLRs and $\mathrm{C}$-type lectin receptors as well as cytoplasmic proteins such as the retinoic acid-inducible gene-I-like receptors and NOD-like receptors (31). PRRs recognize microbial components; for example, C-type lectin receptors Dectin-1 and Dectin-2 are responsible for sensing $\beta$-glucans from fungi, and NOD1 and NOD2 recognize bacterial peptidoglycan-derived structures (31). The TLR family is one of the best-characterized PRR families and are unusual in that some can recognize several structurally unrelated ligands (32). Although they recognize microorganisms, TLRs do not function as phagocytic receptors; however, they can cooperate with other nonopsonic receptors to stimulate phagocytosis (33). In this regard, it is noteworthy that TLR2- and TLR4-signaling have been reported to be required for the maturation of phagosomes containing bacteria (34). Thus, PRRs and the cross-talk between them confer a certain degree of specificity to innate immunity that could underlie the specific increase in bacterial phagocytosis in the absence of FASTK and/or decrease in CI activity.

Accumulating evidence has shown that sensing of Gramnegative bacteria and the exposure to TLR4 ligands decreases OXPHOS and increases glycolysis (35-37). A recent report by Garaude et al. (38) shows that recognition of viable Gramnegative bacteria in fact decreases the abundance of assembled 
A

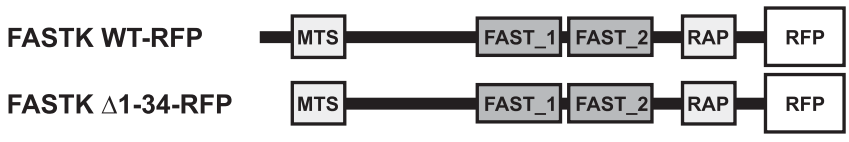

B

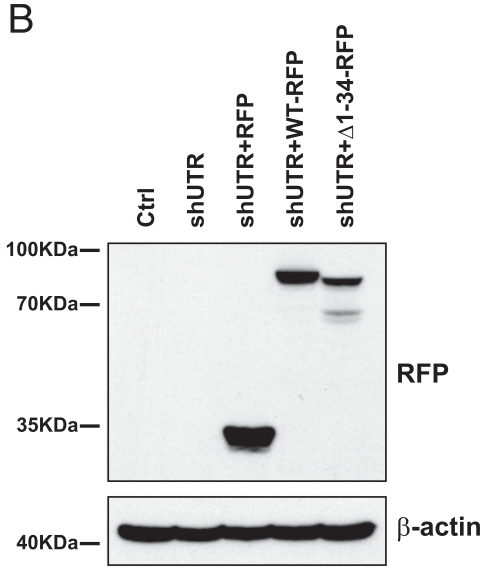

C

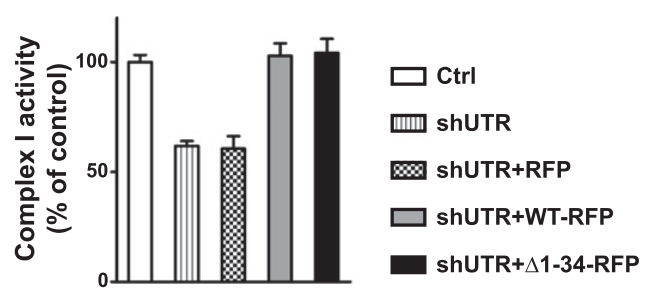

$$
\text { E. coli }
$$

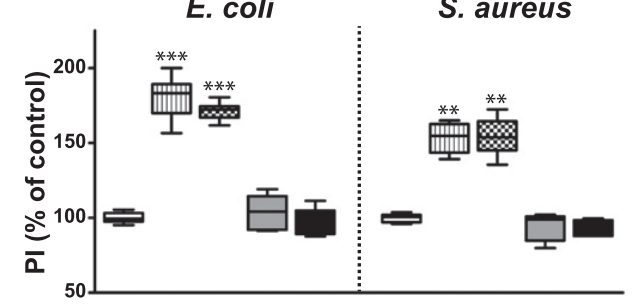

FIGURE 5. Phagocytosis assays in RAW 264.7 cells stably expressing shFASTK (targeting 5'UTR) and rescue constructs. (A) A schematic illustration of RFP-tagged FASTK constructs WT and $\Delta 1-34$. Mitochondrial targeting signal (MTS): three domains conserved among all FASTK family members, FAST_1, FAST_2, and RAP (an acronym for RNA-binding domain abundant in Apicomplexans). (B) RAW 264.7 cells were infected with lentivirus containing pGreenPuro shRNA vector containing either shRNA against the 5'UTR of FASTK (shUTR) or nontargeting shRNA control (Ctrl). Cells expressing shUTR were then stably transfected with RFP-tagged WT FASTK, RFP-tagged mutant FASTK starting at the internal methionine at position $35(\Delta 1-34)$, or RFP alone. Whole cell lysates from each resultant cell line were analyzed by Western blotting using Abs against RFP or $\beta$-actin (loading control). (C) The indicated cell lines were tested for CI activity (top panel) and for phagocytosis with nonopsonized bacteria (bottom panel). CI activities were measured by a NADH dehydrogenase activity assay, and data were normalized to average CI activity of control cells. Means \pm SEM are shown $(n=3$ independent experiments). PI values were normalized to average PI of control cells. Data are represented as box and whiskers plots $(n=3$ independent experiments). $* * p<0.01, * * * p<0.001$.

CI, which results in decreased CI activity and subsequent cellular metabolic adaptations. This metabolic rewiring has also been described upon the activation of toll receptors TLR2 and TLR9 in dendritic cells (39). Still little is known about the impact of this metabolic reprogramming on immune function. Moreover, the importance of certain pre-existing mitochondrial dysfunctions in immune function has also been largely unexplored. In this article, several lines of evidence implicate CI in the modulation of bacterial phagocytosis by macrophages: 1) $\mathrm{FASTK}^{-/}$macrophages show decreased CI activity and increased nonopsonic bacterial phagocytosis, and the re-expression of mitoFASTK alone is able to rescue the phenotype; 2) treatment with rotenone, a specific inhibitor of CI, and shRNA-mediated silencing of NDUFS3 and NDUFS4 also lead to increased phagocytosis of nonopsonized bacteria by macrophages. NDUFS3 is an integral subunit of the Q module of the mitochondrial respiratory CI (26), whereas NDUFS4 is an accessory subunit required for stability of CI (27, 40). Mutations in NDUSF3 and NDUFS4 genes result in Leigh syndrome, a progressive neurodegenerative disorder (41-44).

CI (NADH:ubiquinone oxidoreductase) represents the entry point for most electrons into the respiratory chain. It is a large, multimeric enzyme complex composed of 44 different subunits, the assembly of which is influenced by the oxidative environment. As mentioned above, the recognition of bacteria transiently decreased the assembly and activity of CI (38). In this study, we observed that a decrease in CI, in turn, increases the phagocytic activity against bacteria in macrophages. We speculate that $\mathrm{CI}$ acts as sensor and effector in the regulation of bacterial phagocytosis by macrophages and that this is the result of evolutionary adaptation of macrophages to combat bacteria. The role of FASTK and CI in regulating nonopsonic phagocytosis of bacteria by macrophages represents a novel and exciting finding that deserves further investigation. It is important to mention that $\mathrm{CI}$ deficiency does not lead to a global increase in phagocytosis. This finding suggests that stimuli associated with bacteria contribute to the role of $\mathrm{CI}$ in phagocytosis. Specific bacterial stimuli may underlie the finding that the increase of bacterial phagocytosis associated with CI deficiency is greater for Gram-negative bacteria than for Grampositive bacteria. Finally, it is also important to highlight that the decrease in CI has also been linked to other processes that resemble phagocytosis: efferocytosis and autophagy. In fact, the decrease in CI activity using metformin and rotenone is associated with increased phagocytosis of apoptotic cells and inert particles by microglia (24). Similarly, silencing of CI subunit GRIM-19 in HeLa cells induces autophagy (25).

In this article, we further investigated the molecular mechanisms of action of FASTK protein in regulating the phagocytic capacity of macrophages for nonopsonized bacteria. AMPK is a heterotrimeric kinase consisting of an $\alpha$ catalytic subunit and two regulatory subunits, $\beta$ and $\gamma(45)$. AMPK is activated by phosphorylation of threonine 172 within the catalytic subunit $\alpha$ (45). AMPK is a sensor of energy status that maintains cellular energy homeostasis. In this context, CI dysfunction triggers metabolic response and adaptation that depends on AMPK activation (28). Accordingly, FASTK $^{-1-}$ macrophages show increased basal levels of AMPK $\alpha$ phosphorylation. Exposure to bacteria led to increase in AMPK $\alpha$ phosphorylation, which only was significant for WT macrophages. Bacteria do not increase significantly AMPK $\alpha$ phosphorylation in $\mathrm{FASTK}^{-1-}$ macrophages probably due to the fact that AMPK $\alpha$ is almost fully phosphorylated under basal conditions. 


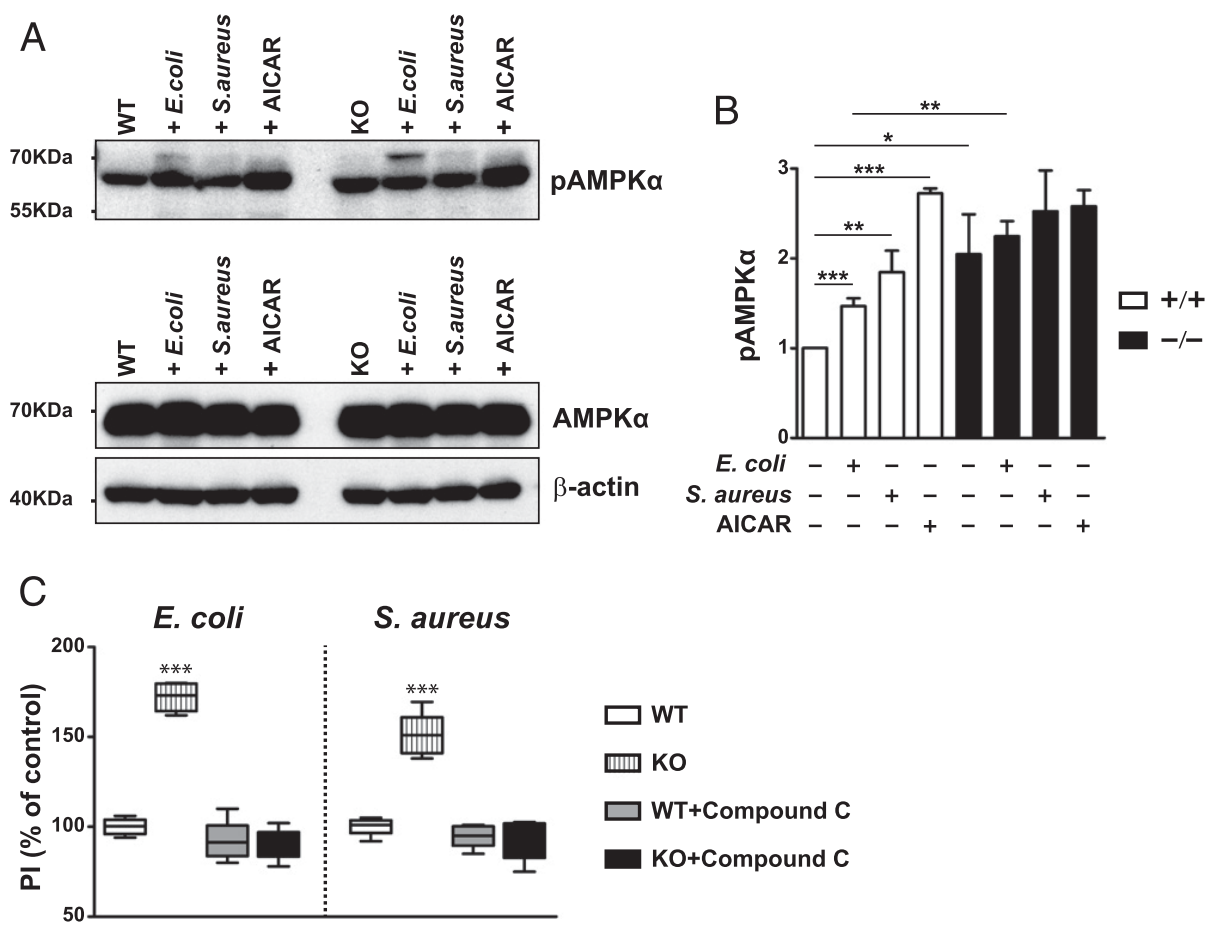

FIGURE 6. AMPK activation increases phagocytosis of bacteria by macrophages. (A) Thioglycolate-elicited peritoneal macrophages from WT mice or FASTK $^{-1-}$ mice were stimulated with either E. coli, S. aureus, or AICAR $(1 \mathrm{mM})$ for $30 \mathrm{~min}$. Cell lysates were subjected to Western blotting using Abs specific to phospho-AMPK (Thr172), AMPK $\alpha$, and actin. Representative Western blots are shown. (B) Quantification of phospho-AMPK (Thr172) Western blotting signals. Values were normalized to AMPK and to control WT untreated macrophages. Values represent the means \pm SEM from four independent experiments. (C) Thioglycolate-elicited peritoneal macrophages from WT mice or FASTK ${ }^{-1}$ mice were incubated in the absence or presence of Compound C: AMPK inhibitor $(10 \mu \mathrm{M}, 30 \mathrm{~min})$ prior to phagocytosis assays. Data were normalized to the average PI of RAW 264.7 cells expressing empty pGreenPuro shRNA vector (control). Data are represented as box and whiskers plots $\left(n=3\right.$ independent experiments). ${ }^{*} p<0.05,{ }^{* *} p<0.01,{ }^{* * *} p<0.001$.

CI dysfunction has also been linked to increased mitochondrial ROS (mitoROS) levels (46). We used MitoSOX to evaluate mitoROS generation in WT and $\mathrm{FASTK}^{-/}$macrophages. As shown in Supplemental Fig. 4B, exposure to bacteria led to an increase in mitoROS generation that was higher in $\mathrm{FASTK}^{-/}$ macrophages compared with WT macrophages. Whether mitoROS plays a role in AMPK activation or in phagocytosis events remains unclear. However, some studies suggest that local production of mitoROS concomitant with TLR-mediated detection could contribute to macrophage bactericidal activity (47). AMPK has been reported to enhance the phagocytic ability of macrophages and neutrophils (29). AICAR treatment increased phagocytosis of bacteria, whereas inclusion of Compound $\mathrm{C}$ in the macrophage cultures prior to AICAR exposure diminished uptake of bacteria (29). Similarly, FASTK $^{--}$macrophages reverted to WT phagocytic phenotype by supplementation of Compound C. AMPK is involved in the microtubule and actin network formation during phagocytosis (29). We show in Supplemental Fig. 4C that FASTK $^{-/-}$macrophages showed increased rise in F-actin content following phagocytosis of $E$. coli. Further studies are needed to unveil the detailed molecular mechanisms by which FASTKmediated activation of AMPK controls phagocytosis. Our work represents the first study, to our knowledge, to document the role of FASTK and respiratory CI in modulating the nonopsonic phagocytosis of bacteria by macrophages. Despite having extensively characterized the phenotype in vitro, it is still necessary to prove its translatability to in vivo models to verify the relevance of this finding in the context of the infection. Even taking into account this limitation, we expect our discovery will open up whole new avenues of investigation that may lead eventually to novel treatments for increasing uptake and clearance of bacteria in infections prior to the initiation of an inflammatory response or in infections in anatomic spaces with limiting amount of opsonins.

\section{Acknowledgments}

We thank Alicia Ortega for technical support.

\section{Disclosures}

The authors have no financial conflicts of interest.

\section{References}

1. Tian, Q., J. Taupin, S. Elledge, M. Robertson, and P. Anderson. 1995. Fasactivated serine/threonine kinase (FAST) phosphorylates TIA-1 during Fasmediated apoptosis. J. Exp. Med. 182: 865-874.

2. Simarro, M., A. Gimenez-Cassina, N. Kedersha, J. B. Lazaro, G. O. Adelmant, J. A. Marto, K. Rhee, S. Tisdale, N. Danial, C. Benarafa, et al. 2010. Fast kinase domain-containing protein 3 is a mitochondrial protein essential for cellular respiration. Biochem. Biophys. Res. Commun. 401: 440-446.

3. Baltz, A. G., M. Munschauer, B. Schwanhäusser, A. Vasile, Y. Murakawa, M. Schueler, N. Youngs, D. Penfold-Brown, K. Drew, M. Milek, et al. 2012. The mRNA-bound proteome and its global occupancy profile on protein-coding transcripts. Mol. Cell 46: 674-690.

4. Castello, A., B. Fischer, K. Eichelbaum, R. Horos, B. M. Beckmann, C. Strein, N. E. Davey, D. T. Humphreys, T. Preiss, L. M. Steinmetz, et al. 2012. Insights into RNA biology from an atlas of mammalian mRNA-binding proteins. Cell 149: 1393-1406.

5. Antonicka, H., K. Choquet, Z. Y. Lin, A. C. Gingras, C. L. Kleinman, and E. A. Shoubridge. 2017. A pseudouridine synthase module is essential for mitochondrial protein synthesis and cell viability. EMBO Rep. 18: 28-38.

6. Antonicka, H., and E. A. Shoubridge. 2015. Mitochondrial RNA granules are centers for posttranscriptional RNA processing and ribosome biogenesis. Cell Rep. 10: 920-932.

7. Boehm, E. S. Zaganelli, K. Maundrell, A. A. Jourdain, S. Thore, and J. C. Martinou. 2017. FASTKD1 and FASTKD4 have opposite effects on expression of specific mitochondrial RNAs, depending upon their endonucleaselike RAP domain. Nucleic Acids Res. 45: 6135-6146.

8. Boehm, E., M. Zornoza, A. A. Jourdain, A. Delmiro Magdalena, I. GarcíaConsuegra, R. Torres Merino, A. Orduña, M. A. Martín, J. C. Martinou, 
M. A. De la Fuente, and M. Simarro. 2016. Role of FAST kinase domains 3 (FASTKD3) in post-transcriptional regulation of mitochondrial gene expression. J. Biol. Chem. 291: 25877-25887.

9. Han, S., N. D. Udeshi, T. J. Deerinck, T. Svinkina, M. H. Ellisman, S. A. Carr, and A. Y. Ting. 2017. Proximity biotinylation as a method for mapping proteins associated with mtDNA in living cells. Cell Chem Biol 24: 404-414.

10. Popow, J., A. M. Alleaume, T. Curk, T. Schwarzl, S. Sauer, and M. W. Hentze 2015. FASTKD2 is an RNA-binding protein required for mitochondrial RNA processing and translation. RNA 21: 1873-1884.

11. Wolf, A. R., and V. K. Mootha. 2014. Functional genomic analysis of human mitochondrial RNA processing. Cell Rep. 7: 918-931.

12. Jourdain, A. A., M. Koppen, C. D. Rodley, K. Maundrell, N. Gueguen, P. Reynier, A. M. Guaras, J. A. Enriquez, P. Anderson, M. Simarro, and J. C. Martinou. 2015. A mitochondria-specific isoform of FASTK is present in mitochondrial RNA granules and regulates gene expression and function. Cell Rep. 10: 1110-1121.

13. Kedersha, N., G. Stoecklin, M. Ayodele, P. Yacono, J. Lykke-Andersen, M. J. Fritzler, D. Scheuner, R. J. Kaufman, D. E Golan, and P. Anderson. 2005. Stress granules and processing bodies are dynamically linked sites of mRNP remodeling. J. Cell Biol. 169: 871-884.

14. Li, W., M. Simarro, N. Kedersha, and P. Anderson. 2004. FAST is a survival protein that senses mitochondrial stress and modulates TIA-1-regulated changes in protein expression. Mol. Cell. Biol. 24: 10718-10732.

15. Izquierdo, J. M., and J. Valcárcel. 2007. Fas-activated serine/threonine kinase (FAST K) synergizes with TIA-1/TIAR proteins to regulate Fas alternative splicing. J. Biol. Chem. 282: 1539-1543.

16. Simarro, M., D. Mauger, K. Rhee, M. A. Pujana, N. L. Kedersha, S. Yamasaki, M. E. Cusick, M. Vidal, M. A. Garcia-Blanco, and P. Anderson. 2007. Fasactivated serine/threonine phosphoprotein (FAST) is a regulator of alternative splicing. Proc. Natl. Acad. Sci. USA 104: 11370-11375.

17. Brutsche, M. H., I. C. Brutsche, P. Wood, A. Brass, N. Morrison, M. Rattay, N. Mogulkoc, N. Simler, M. Craven, A. Custovic, et al. 2001. Apoptosis signals in atopy and asthma measured with cDNA arrays. Clin. Exp. Immunol. 123: 181187.

18. Maas, K., S. Chan, J. Parker, A. Slater, J. Moore, N. Olsen, and T. M. Aune 2002. Cutting edge: molecular portrait of human autoimmune disease. $J$. Immunol. 169: 5-9.

19. Simarro, M. G. Giannattasio, M. A. De la Fuente, C. Benarafa, K. K. Subramanian, R. Ishizawar, B. Balestrieri, E. M. Andersson, H. R. Luo, A. Orduña, et al. 2010. Fas-activated serine/threonine phosphoprotein promotes immune-mediated pulmonary inflammation. J. Immunol. 184: 5325-5332.

20. Simarro, M., M. Chen, M. A. De la Fuente, J. M. Eiros, A. Orduña, and P. Anderson. 2016. Deletion of FAST (Fas-activated serine/threonine phosphoprotein) ameliorates immune complex arthritis in mice. Mod. Rheumatol. 26: protein) $630-632$.

21. Medja, F., S. Allouche, P. Frachon, C. Jardel, M. Malgat, B. Mousson de Camaret, A. Slama, J. Lunardi, J. P. Mazat, and A. Lombès. 2009. Developmen and implementation of standardized respiratory chain spectrophotometric assays for clinical diagnosis. Mitochondrion 9: 331-339.

22. Granger, B. L. S. A. Green, C. A. Gabel, C. L. Howe, I. Mellman, and A. Helenius. 1990. Characterization and cloning of lgp110, a lysosomal
membrane glycoprotein from mouse and rat cells. J. Biol. Chem. 265: 1203612043 .

23. Howe, C. L., B. L. Granger, M. Hull, S. A. Green, C. A. Gabel, A. Helenius, and I. Mellman. 1988. Derived protein sequence, oligosaccharides, and membrane insertion of the 120-kDa lysosomal membrane glycoprotein (lgp120): identification of a highly conserved family of lysosomal membrane glycoproteins. Proc. Natl. Acad. Sci. USA 85: 7577-7581.

24. Emmrich, J. V., T. C. Hornik, J. J. Neher, and G. C. Brown. 2013. Rotenone induces neuronal death by microglial phagocytosis of neurons. FEBS J. 280 5030-5038.

25. Yue, X., P. Zhao, K. Wu, J. Huang, W. Zhang, Y. Wu, X. Liang, and X. He. 2016. GRIM-19 inhibition induced autophagy through activation of ERK and HIF-10 not STAT3 in Hela cells. Tumour Biol. 37: 9789-9796.

26. Vogel, R. O., C. E. Dieteren, L. P. van den Heuvel, P. H. Willems, J. A. Smeitink, W. J. Koopman, and L. G. Nijtmans. 2007. Identification of mitochondrial complex I assembly intermediates by tracing tagged NDUFS3 demonstrates the entry point of mitochondrial subunits. J. Biol. Chem. 282: 7582-7590.
27. Kruse, S. E., W. C. Watt, D. J. Marcinek, R. P. Kapur, K. A. Schenkman, and R. D. Palmiter. 2008. Mice with mitochondrial complex I deficiency develop a fatal encephalomyopathy. Cell Metab. 7: 312-320.

28. Distelmaier, F., F. Valsecchi, D. C. Liemburg-Apers, M. Lebiedzinska, R. J. Rodenburg, S. Heil, J. Keijer, J. Fransen, H. Imamura, K. Danhauser, et al. 2015. Mitochondrial dysfunction in primary human fibroblasts triggers an adaptive cell survival program that requires AMPK- $\alpha$. Biochim. Biophys. Acto 1852: 529-540.

29. Bae, H. B., J. W. Zmijewski, J. S. Deshane, J. M. Tadie, D. D. Chaplin S. Takashima, and E. Abraham. 2011. AMP-activated protein kinase enhance the phagocytic ability of macrophages and neutrophils. FASEB J. 25: 4358-4368.

30. Reynolds, H. Y., and H. H. Newball. 1974. Analysis of proteins and respiratory cells obtained from human lungs by bronchial lavage. J. Lab. Clin. Med. 84: 559-573.

31. Takeuchi, O., and S. Akira. 2010. Pattern recognition receptors and inflammation. Cell 140: 805-820.

32. Akira, S., S. Uematsu, and O. Takeuchi. 2006. Pathogen recognition and innate immunity. Cell 124: 783-801.

33. Iwasaki, A., and R. Medzhitov. 2015. Control of adaptive immunity by the innate immune system. Nat. Immunol. 16: 343-353.

34. Blander, J. M., and R. Medzhitov. 2004. Regulation of phagosome maturation by signals from toll-like receptors. Science 304: 1014-1018.

35. Lachmandas, E., L. Boutens, J. M. Ratter, A. Hijmans, G. J. Hooiveld, L. A. Joosten, R. J. Rodenburg, J. A. Fransen, R. H. Houtkooper, R. van Crevel, et al. 2016. Microbial stimulation of different Toll-like receptor signalling pathways induces diverse metabolic programmes in human monocytes. Nat. Microbiol. 2: 16246.

36. Tannahill, G. M., A. M. Curtis, J. Adamik, E. M. Palsson-McDermott, A. F. McGettrick, G. Goel, C. Frezza, N. J. Bernard, B. Kelly, N. H. Foley, et al. 2013. Succinate is an inflammatory signal that induces IL-1 $\beta$ through HIF-1 $\alpha$. Nature 496: 238-242.

37. Sancho, D., M. Enamorado, and J. Garaude. 2017. Innate immune function of mitochondrial metabolism. Front. Immunol. 8: 527.

38. Garaude, J., R. Acín-Pérez, S. Martínez-Cano, M. Enamorado, M. Ugolini, E. Nistal-Villán, S. Hervás-Stubbs, P. Pelegrín, L. E. Sander, J. A. Enríquez, and D. Sancho. 2016. Mitochondrial respiratory-chain adaptations in macrophages contribute to antibacterial host defense. Nat. Immunol. 17: 1037-1045.

39. Krawczyk, C. M., T. Holowka, J. Sun, J. Blagih, E. Amiel, R. J. DeBerardinis, J. R. Cross, E. Jung, C. B. Thompson, R. G. Jones, and E. J. Pearce. 2010. Tolllike receptor-induced changes in glycolytic metabolism regulate dendritic cell activation. Blood 115: 4742-4749.

40. Kahlhöfer, F., K. Kmita, I. Wittig, K. Zwicker, and V. Zickermann. 2017. Accessory subunit NUYM (NDUFS4) is required for stability of the electron input module and activity of mitochondrial complex I. Biochim. Biophys. Acta 1858: module and

41. Bénit, P., A. Slama, F. Cartault, I. Giurgea, D. Chretien, S. Lebon, C. Marsac A. Munnich, A. Rötig, and P. Rustin. 2004. Mutant NDUFS3 subunit of mitochondrial complex I causes Leigh syndrome. J. Med. Genet. 41: 14-17.

42. Jaokar, T. M., D. P. Patil, Y. S. Shouche, S. M. Gaikwad, and C. G. Suresh. 2013. Human mitochondrial NDUFS3 protein bearing Leigh syndrome mutation is more prone to aggregation than its wild-type. Biochimie 95: 2392-2403.

43. Ortigoza-Escobar, J. D., A. Oyarzabal, R. Montero, R. Artuch, C. Jou, C. Jiménez, L. Gort, P. Briones, J. Muchart, E. López-Gallardo, et al. 2016 Ndufs4 related Leigh syndrome: a case report and review of the literature Mitochondrion 28: 73-78

44. Pagniez-Mammeri, H., S. Loublier, A Legrand, P. Bénit, P. Rustin, and A. Slama. 2012. Mitochondrial complex I deficiency of nuclear origin I. Structural genes. Mol. Genet. Metab. 105: 163-172.

45. Carling, D. 2017. AMPK signalling in health and disease. Curr. Opin. Cell Biol. 45: $31-37$.

46. Koopman, W. J., S. Verkaart, H. J. Visch, F. H. van der Westhuizen, M. P. Murphy, L. W. van den Heuvel, J. A. Smeitink, and P. H. Willems. 2005. Inhibition of complex I of the electron transport chain causes O2-, -mediated mitochondrial outgrowth. Am. J. Physiol. Cell Physiol. 288: C1440-C1450.

47. West, A. P., I. E. Brodsky, C. Rahner, D. K. Woo, H. Erdjument-Bromage P. Tempst, M. C. Walsh, Y. Choi, G. S. Shadel, and S. Ghosh. 2011. TLR signalling augments macrophage bactericidal activity through mitochondrial ROS Nature 472: 476-480. 

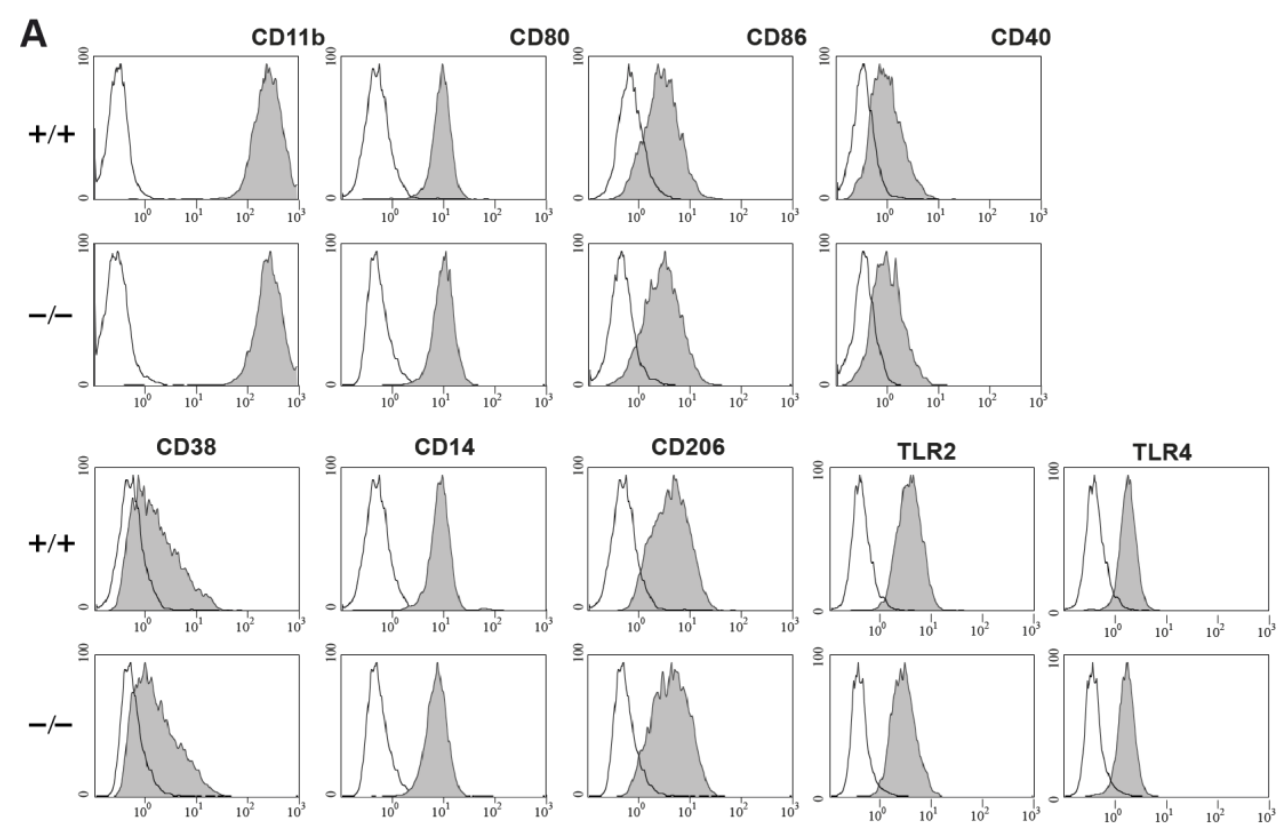

B

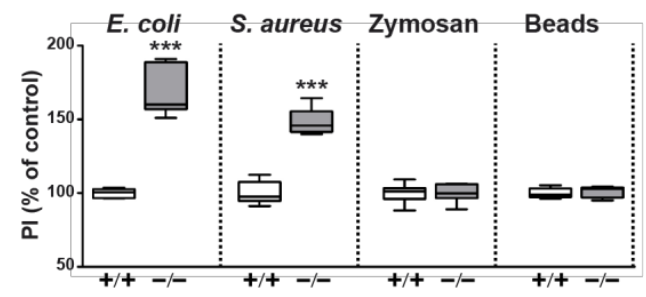

D

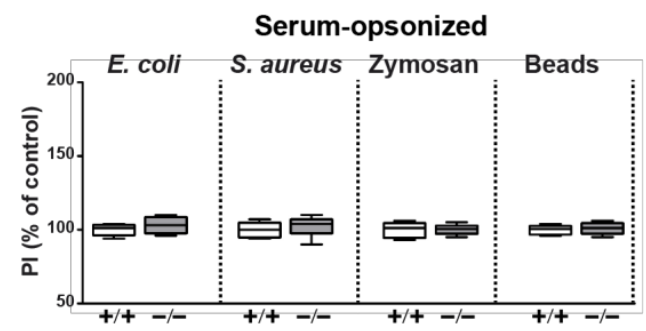

C

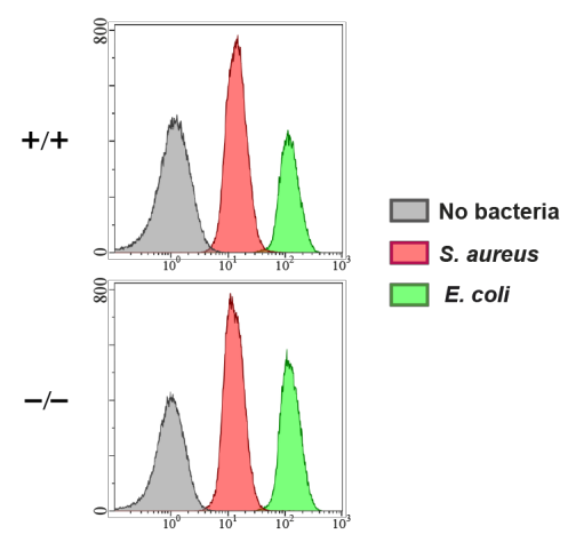

Supplemental Figure 1. (A) Peritoneal macrophages from $\mathrm{FASTK}^{--}$and WT mice were analyzed by flow cytometry to evaluate the expression of the indicated key cell surface markers expressed on F4/80+ macrophages. Cell surface marker staining (solid grey) and unstained (black line) cells are shown. Histograms are representative of 3 independent experiments using pooled thioglycolate-elicited peritoneal macrophages from 3 mice per group per experiment. (B) Macrophages were incubated with non-opsonized phagocytic particles for 15 min. PI values were normalized to average PI of control cells. Data are represented as box and whiskers plots, $\mathrm{n}=3$ independent experiments. (C) Peritoneal macrophages from FASTK ${ }^{-1}$ and WT mice were incubated in serum/antibiotics free conditions with non-opsonized FITC-labeled bacteria on ice for $30 \mathrm{~min}$. Bacterial adherence to macrophages was quantified by flow cytometry. Histograms are representative of $n=3$ independent experiments. (D) Peritoneal macrophages from FASTK ${ }^{-/}$and WT mice were incubated with serum-opsonized phagocytic particles for 30 min. PI values were normalized to average PI of control cells. Data are represented as box and whiskers plots, $n$ $=5$ independent experiments. 
A

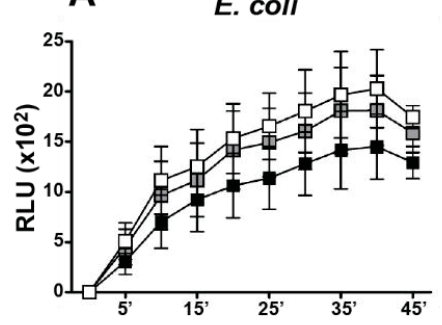

S. aureus

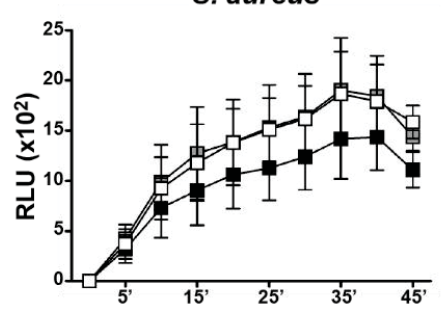

$\square+/+\square$-/- $\square \operatorname{Rot} 30$ nM
B
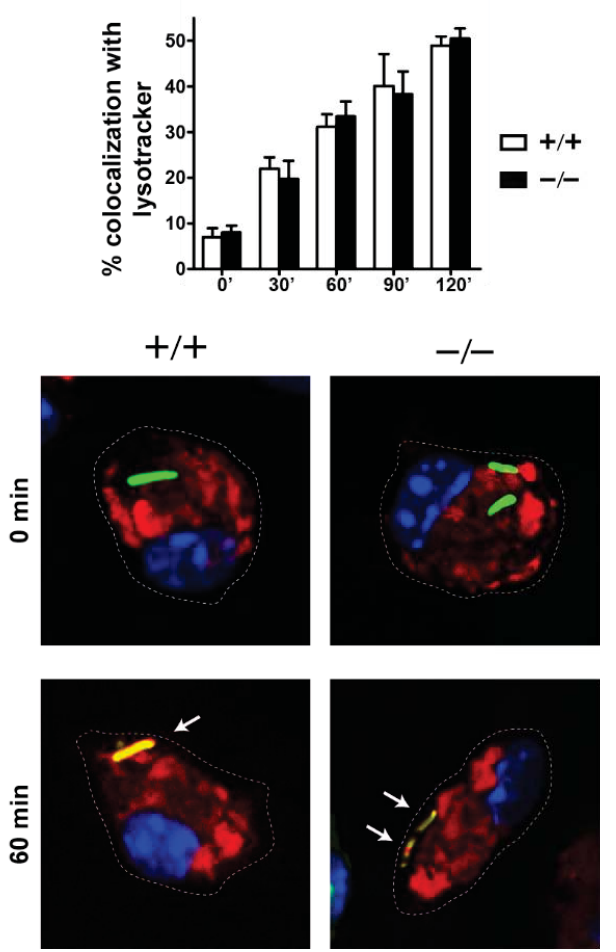

Supplemental Figure 2. (A) $\mathrm{FASTK}^{-/}$peritoneal macrophages and WT peritoneal macrophages, either untreated or preincubated with $30 \mathrm{nM}$ rotenone for at least $4 \mathrm{~h}$, were exposed to bacteria for the indicated time periods. Total production of ROS in the presence of the indicated bacteria was analyzed by chemiluminescence dependent luminol assay in the presence of HRP as described in Material and Methods. Data are expressed in relative light units (RLU). Means \pm SEM are shown ( $>6$ independent experiments). (B) FASTK ${ }^{-l}$ and WT peritoneal macrophages seeded on glass coverslips were pulsed with non-opsonized GFP-expressing E. coli for $15 \mathrm{~min}$, followed by various periods of chase in the presence of gentamicin (at $100 \mu \mathrm{g} / \mathrm{ml}$ ). Cells were loaded with Lysotracker Red DND-99 (500 nM) for 5 min before being fixed with 4\% paraformaldehyde and then visualized using confocal microscopy. The percentages of green E. coli-containing phagosomes that were colocalized with Lysotracker Red at various time points are represented in the top panel. Data are mean \pm SEM $(\mathrm{n}=3)$. The bottom panel shows representative pictures at time points 0 and $60 \mathrm{~min}$. Yellow signals (marked with arrows) indicate colocalization of E.coli with lysosomes. Nuclei were stained with Hoechst 33342. 
A

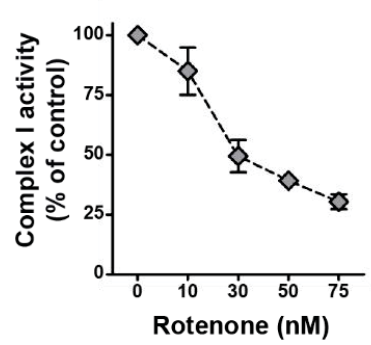

B

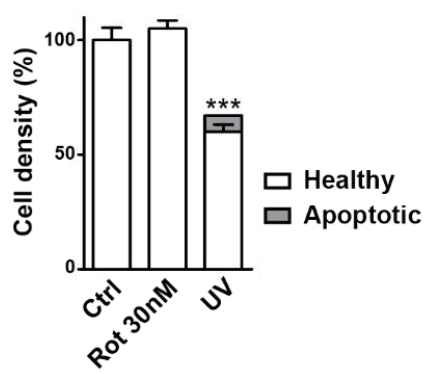

C

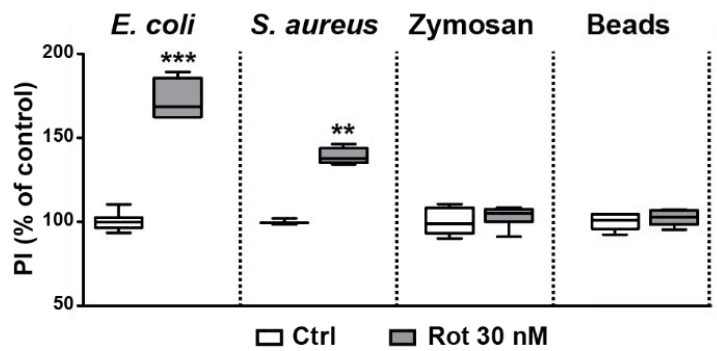

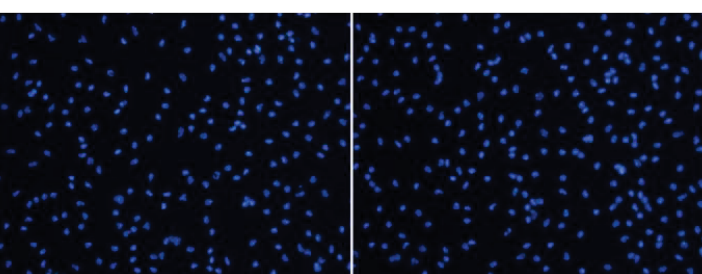

Control
Rotenone

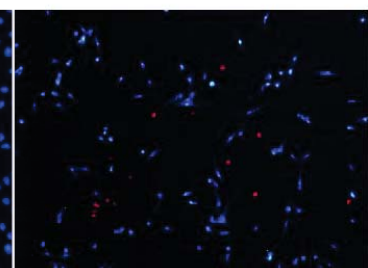

UV

Supplemental Figure 3. (A) Peritoneal macrophages from WT mice were treated with different concentrations of rotenone $(0,10,30,50$ and $75 \mathrm{nM})$ for $24 \mathrm{~h}$ and Complex I activity was measured by a NADH dehydrogenase activity assay. Data are expressed as percentages of activities relative to untreated control cells (set at $100 \%$ ). Means \pm SEM are shown (n=3). (B) Peritoneal macrophages from WT mice were treated with rotenone (30 nM, $24 \mathrm{~h}$ ) or induced to undergo apoptosis by exposure to UV radiation $(100 \mathrm{~mJ})$. Cell viability was assessed by trypan blue exclusion and apoptosis was measured by the TUNEL assay combined with Hoechst stain. Data were normalized to untreated control and presented as means \pm SEM $(n=3)$. The right panel shows representative images of double staining with TUNEL (red) and Hoechst (blue) used to obtain the data presented in the left panel (original magnification 20x). (C) Peritoneal macrophages from WT mice were treated with rotenone (30 nM) for $24 \mathrm{~h}$, then incubated with non-opsonized bacteria, zymosan and inert latex beads for $15 \mathrm{~min}$. PI values were normalized to average PI of control cells. Data are represented as box and whiskers plots, $n=3$ independent experiments. 
A

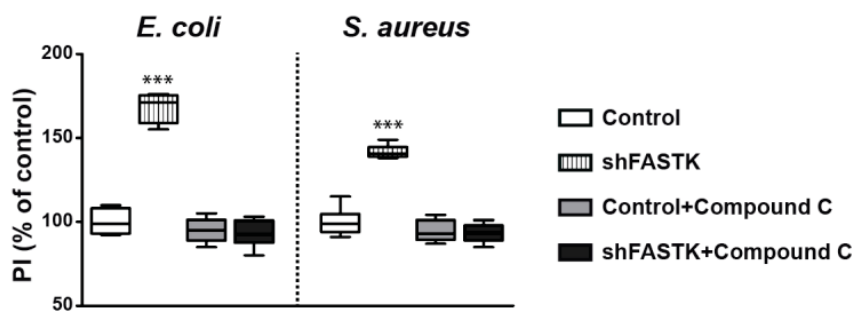

B

E. coli

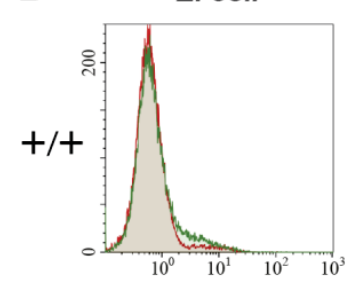

S. aureus

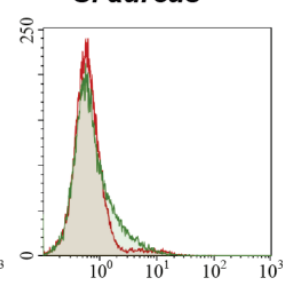

$-1-=\frac{10^{\circ} \text { 10 } 10^{1}}{10^{3}}$

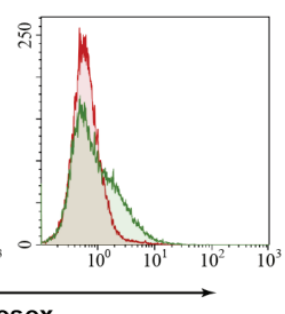

$\square$ Untreated

$\square$ Bacteria

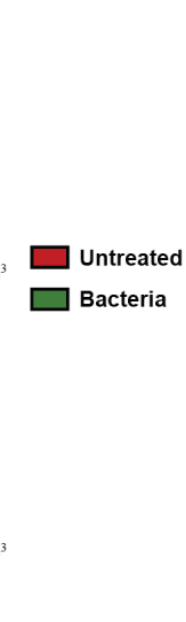

C
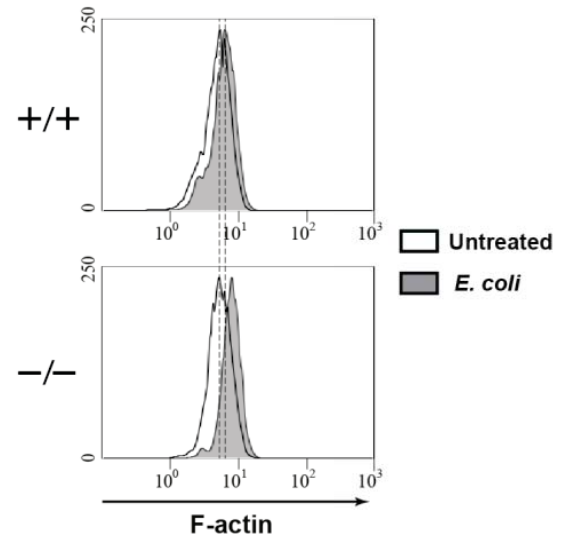

Supplemental Figure 4. (A) RAW 264.7 cells stably expressing shRNA against FASTK CDS were incubated in the absence or presence of compound C: AMPK inhibitor $(10 \mu \mathrm{M}, 30 \mathrm{~min})$ prior to phagocytosis assays. Data were normalized to the average PI of RAW 264.7 cells expressing non-targeting shRNA (control). Data are represented as box and whiskers plots, $\mathrm{n}=3$ independent experiments. (B) Analysis of mitoROS generation in FASTK $^{--}$macrophages. Peritoneal macrophages from $\mathrm{FASTK}^{--}$and WT mice were incubated in the absence or presence of the indicated bacteria for $15 \mathrm{~min}$ at $37^{\circ} \mathrm{C}$. Cells were then stained with $2.5 \mu \mathrm{M}$ MitoSOX or left unstained, and analyzed by flow cytometry. Representative flow cytometry histograms are shown; $\mathrm{n}=6$ independent experiments. (C) Analysis of F-actin content. Peritoneal macrophages from FASTK ${ }^{-1}$ and WT mice were incubated in the absence or presence of $E$. coli for $30 \mathrm{~min}$ at $37^{\circ} \mathrm{C}$. Cells were stained with TRITC phalloidin and analyzed by flow cytometry. Representative flow cytometry histograms are shown; $\mathrm{n}=3$ independent experiments. 